PACIFIC LINGUISTICS

Series C - No.109

\title{
URAK LAWOI': BASIC STRUCTURES AND A DICTIONARY
}

\author{
David W. Hogan \\ in collaboration with \\ Stephen W. Pattemore
}

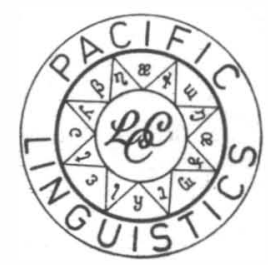

Department of Linguistics

Research School of Pacific Studies

THE AUSTRALIAN NATIONAL UNIVERSITY 
PACIFIC LINGUISTICS is issued through the Linguistic Circle of Canberra and consists of four series:

$\begin{array}{ll}\text { SERIES A: Occasional Papers } & \text { SERIES C: Books } \\ \text { SERIES B: Monographs } & \text { SERIES D: Special Publications }\end{array}$

FOUNDING EDITOR: S.A. Wurm

EDITORIAL BOARD: D.C. Laycock, D.T. Tryon, T.E. Dutton, M.D. Ross

EDITORIAL ADVISERS:

B.W. Bender

University of Hawaii

David Bradley

La Trobe University

Michael G. Clyne

Monash University

S.H. Elbert

University of Hawaii

K.J. Franklin

Summer Institute of Linguistics

W.W. Glover

Summer Institute of Linguistics

G.W. Grace

University of Hawaii

M.A.K. Halliday

University of Sydney

E. Haugen

Harvard University

A. Healey

Summer Institute of Linguistics

L.A. Hercus

Australian National University

John Lynch

University of Papua New Guinea

K.A. McElhanon

Summer Institute of Linguistics
H.P. McKaughan

University of Hawaii

P. Mühlhäusler

Bond University

G.N. O'Grady

University of Victoria, B.C.

A.K. Pawley

University of Auckland

K.L. Pike

Summer Institute of Linguistics

E.C. Polomé

University of Texas

Gillian Sankoff

University of Pennsylvania

W.A.L. Stokhof

University of Leiden

B.K. T'sou

City Polytechnic of Hong Kong

E.M. Uhlenbeck

University of Leiden

J.W.M. Verhaar

Divine Word Institute, Madang

C.L. Voorhocve

University of Leiden

All correspondence concerning PACIFIC LINGUISTICS, including orders and subscriptions, should be addressed to:

PACIFIC LINGUISTICS

Department of Linguistics

Research School of Pacific Studies

The Australian National University

Australia

Canberra, A.C.T. 2601

Copyright (C) The Authors

Computer typeset by Evelyn H.M. Winburn

First Published 1988

Printed by A.N.U. Printing Service

Maps drawn by Theo Baumann

Bound by Adriatic Bookbinders Pty Ltd

The editors are indebted to the Australian National University for assistance in the production of this series

This publication was made possible by an initial grant from the Hunter Douglas Fund.

ISSN 0078-7558

ISBN 0858833859 


\section{TABLE OF CONTENTS}

ACKNOWLEDGEMENTS iv

MAP OF TRIBAL LOCATIONS ON THE WEST COAST OF SOUTH THAILAND \& v

ABBREVIATIONS AND SYMBOLS vi

Chapter

\section{1}

1.1

1.2

1.3

1.4

2

2.1

2.2

2.3

2.4

2.5

3

3.1

3.2

4

4.1

4.2

\section{INTRODUCTION}

Purpose and Scope of the Study

Geographical, historical, and linguistic setting of Urak Lawoi'

Theoretical framework adopted for the description

Methodology and phonemic alphabet

PHONEME LEVEL

Outline of the syllable and word

Phonetic structure of the phoneme

Suprasegmental Features

Function of the phoneme in the syllable

Variations found in Adang and Phuket Young People dialects

\section{WORD LEVEL}

Structure of the word

Function of the word

PHRASE LEVEL

Types of phrase structure

Classes of phrase function

NOTES

REFERENCES

URAK LAWOI'-ENGLISH DICTIONARY

Introduction

Notes on pronunciation

Dictionary Abbreviations

Urak Lawoi'-English dictionary

103

ENGLISH-URAK LAWOI' FINDERLIST 


\section{ACKNOWLEDGEMENTS}

I am grateful to all who have assisted me in the study of the Urak Lawoi' language. I have had much help from members of the Summer Institute of Linguistics and the United Bible Societies.

I am indebted to Mr Robert Petterson and the Computer Centre of Massey University, Palmerston North, New Zealand, for their assistance in compiling the computer concordance used in the analysis of this language.

For the help of the late Nai Wong and my other Urak Lawoi' informants, and for all the help and encouragement of my wife, Doreen, I give grateful thanks indeed.

David W. Hogan

Phuket, 13th March 1989 


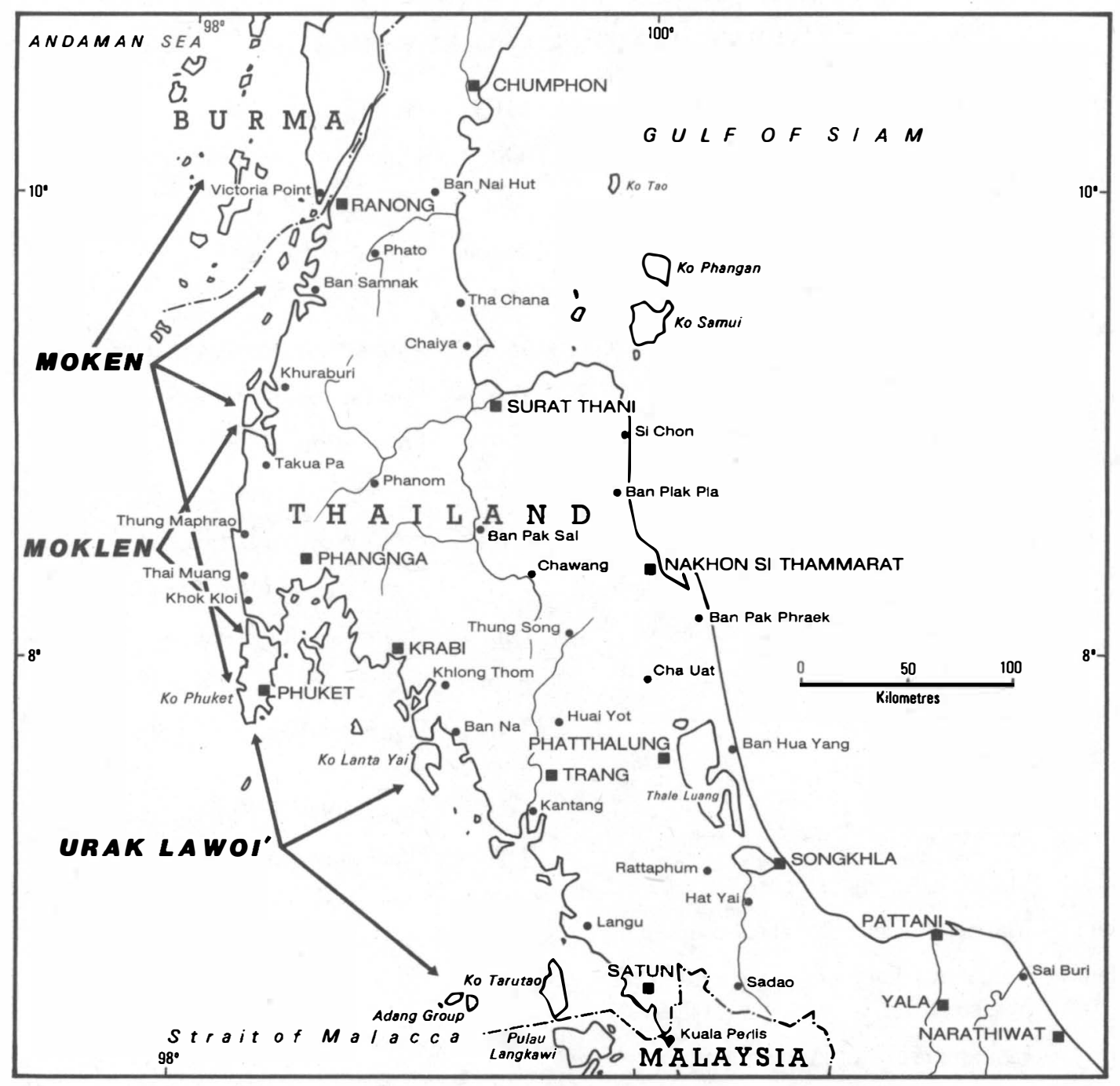

TRIBAL LOCATIONS ON THAILAND'S WEST COAST 


\section{ABBREVIATIONS AND SYMBOLS}

Acc: Accompaniment Adjunct slot at Clause Level

$\mathrm{AD}$ Adang or Southern dialect

Adj: Adjunct slot in the verb phrase

Aux: Auxiliary slot in the verb phrase

Ax: Axis slot in the prepositional phrase

C any consonant

CLW Chinese loanword

Co: Coda slot at Clause Level

ELW English loanword

Ex: Extent Adjunct slot at Clause Level

Faux: Final auxiliary slot in the verb phrase

$\mathrm{H}$ : $\quad$ Head slot in the noun phrase

HV: Head verb slot in the verb phrase

Inst: Instrumental Adjunct slot at Clause Level

Int: Intensifier slot in the verb phrase

Loc: Location Adjunct slot at Clause Level

Man: Manner Adjunct slot at Clause Level

Maux: Modal auxiliary slot in the verb phrase

Mf: Final marker slot in the noun phrase

Mi: Initial marker slot in the noun phrase

MKL Moklen

MKN Moken

MLW Malay loanword

Mod: Modifier slot at Phrase Level

$\mathrm{N}$ any nasal consonant
NP Noun Phrase

Obj: Object slot at Clause Level

Obs Obsolete word

Paren: Parenthetical slot at Sentence Level

POL Proto Orang Laut

POP Phuket Old People's dialect

Pos: Possessor slot in the noun phrase

PP Prepositional Phrase

Pred: Predicate slot at Clause Level

PWI Proto Westem Indonesian

PYP Phuket Young People's dialect

Qn: Quantifier slot at Phrase Level

Subj: Subject slot at Clause Level

Tem: Temporal Adjunct slot at Clause Level

Top: Topic slot at Sentence Level

TLW Thai loanword

U Utterance

UL Urak Lawoi'

$\mathrm{V}$ any vowel

Voc Vocative word

VP Verb Phrase

VPac Action Verb Phrase

VPeq Equative Verb Phrase

VPst Stative Verb Phrase

Vul Vulgar word

apt auxiliary particle

av adverbs of all classes 


\begin{tabular}{|c|c|c|c|}
\hline ava & adverb of accompaniment & $\mathrm{npl}$ & proper noun, locational \\
\hline ave & adverb of extent & npp & proper noun, personal \\
\hline avi & adverb of instrument & num & simple or complex numeral, or a \\
\hline avl & adverb of location & & number plus a numerical classifier \\
\hline avm & adverb of manner & pn & pronouns of all classes \\
\hline avq & adverb of interrogation & ppn & personal pronoun \\
\hline avt & adverb of time & ppt & prepositional particle \\
\hline $\mathrm{cc}$ & coordinating conjunction & prep & specific preposition \\
\hline $\mathrm{cl}$ & classifier & $\mathrm{pt}$ & particle \\
\hline $\operatorname{clm}$ & classifier, metrical & qpn & interrogative pronoun \\
\hline $\operatorname{cln}$ & classifier, numerical & qpt & interrogative particle \\
\hline cpt & conjunctive particle & res & response word \\
\hline cs & subordinating conjunction & rpn & relative pronoun \\
\hline $\operatorname{csf}$ & final subordinating conjunction & spt & syntactic particle \\
\hline dpn & demonstrative pronoun & vac & action verb \\
\hline dpt & final determiner particle & vacbt & action verb, bi-transitive \\
\hline dpti & initial determiner particle & vaci & action verb, intransitive \\
\hline ept & emphatic particle & vact & action verb, transitive \\
\hline exc & exclamation & vaj & adjectival verb \\
\hline excl & pronoun which excludes the person & vaux & auxiliary verb \\
\hline & addressed & $\mathrm{vb}$ & verb \\
\hline incl & pronoun which includes the person & vcop & copula verb \\
\hline & & vpt & verbal particle \\
\hline ipn & indefinite pronoun & vsp & verb of saying or perceiving \\
\hline $\mathrm{mpt}$ & modal particle & \# & marker of elicited text \\
\hline nab & abstract noun & $*$ & marker of unacceptable text \\
\hline nca & common noun, animate & + & an item obligatorily present \\
\hline nch & common noun, human & - & an item obligatorily absent \\
\hline nci & common noun, inanimate & \pm & an optional item \\
\hline $\mathrm{ncl}$ & noun cluster & $"$ & signals that the following syllable \\
\hline nco & coordinated nouns & & bears major stress \\
\hline $\begin{array}{l}\text { neg } \\
\text { nn }\end{array}$ & $\begin{array}{l}\text { negative word } \\
\text { nouns of all classes }\end{array}$ & ' & $\begin{array}{l}\text { signals that the following syllable } \\
\text { bears minor stress }\end{array}$ \\
\hline
\end{tabular}




\section{CHAPTER 1}

\section{INTRODUCTION}

\subsection{Purpose and scope of the study}

The purpose of this work is to analyse and describe the basic structures of the Urak Lawoi' language and their functions. These structures and functions range from the phonology to the level of the phrase.

There is no standard form of Urak Lawoi' and pronunciation and usage vary from village to village. Three main dialects of the language have been identified, which have been called: Phuket Old People's dialect (POP), Phuket Young People's dialect (PYP), and the Southem or Adang dialect (AD). This study concentrates on the Phuket Old People's dialect as it has the most phonological contrasts, and many of the forms of the other dialects can be derived from it. Reference is made to the other dialects where it is appropriate.

\subsection{Geographical, historical, and linguistic setting of Urak Lawoi'}

\subsubsection{Geographical}

The Urak Lawoi' are a tribe of approximately 3000 people, located in villages on the islands off the west coast of Thailand from Phuket Island to the Adang Island group, as shown on the location map. Phonemically, their name Urak Lawoi' is written as /urak lawoc/ meaning "men of the sea". Malay sources refer to them as Orang Laut, the Malay term for "men of the sea".

\subsubsection{Historical}

Historically, there have been references to "Sea Gypsies" in this area since the seventeenth century, although the details are vague. The Urak Lawoi' themselves say that Lanta Island is their original home from which they have spread to their present locations. Their legends refer to Mount Jerai on the mainland of Malaysia, near Penang, as their centre in the remote past.

When Sopher published his study of "The Sea Nomads" in 1965, he referred only briefly to the "Orang Laut", quoting Annandale (Annandale and Robinson 1903) as having met them in the vicinity of Trang. He assumed the absence of further reference implied that they had virtually ceased to exist (Soper 1965:346). White (1922) and Bernatzik (1958) spoke of them as the Orang Lawta but regarded them as members of the Moken tribe who had intermarried with Malays and settled in this area. 
There has been a tendency to confuse the Urak Lawoi' with the Moken. Lebar, Hickey and Musgrave grouped them together in their "Ethnic groups of mainland South-East Asia" (1964). The National Geographic Society map of "Peoples of mainland Southeast Asia" (Anonymous 1971), based on this publication, uses the name "Moken" to include both the Moken and Urak Lawoi' peoples.

I have previously described how the Urak Lawoi' were still in existence, maintaining their tribal identity and language, and were quite distinct from the Moken people (Hogan 1972).

\subsubsection{Linguistic}

Papers on the Urak Lawoi' phonology by myself (Hogan 1976) and Amon Saengmani (1979) have shown a similar phonemic pattern for the northern and southern groups of the tribe, while Veena Chantanakomes' thesis (1980) on the Moken phonology and syntax shows a different pattern in that language.

Sorat Makboon has surveyed the dialects of the sea people tribes along the west coast of Thailand. He sampled the language spoken at ten localities along the coast, in five Urak Lawoi' villages and five Moken-Moklen villages. He found that the cognate percentages in the Urak Lawoi' villages ranged from $95.65 \%$ to $98.37 \%$, showing it is one language. The cognate percentages in the Moken and Moklen villages ranged from $89.67 \%$ to $95.11 \%$, showing that it also is one language. But when Moken was compared with Urak Lawoi', the cognate percentages ranged from $45.65 \%$ to $50 \%$ (Sorat 1981:47). In terms of Swadesh's classification as described by Gudschinsky (1964:621), this indicates that Urak Lawoi' and Moken are not the same language, but are members of the same family (Sorat 1981:14-17,81). He further states that there is a lexico-statistical ratio between Urak Lawoi' and Malay of $81.87 \%$ to $88.52 \%$, while the ratio between Moken and Malay is only $44.51 \%$ to $45.60 \%$. From this he concludes that Urak Lawoi' and Malay are the same language, while Moken is more distantly related to Malay, but belonging to the same family. He therefore classes both Urak Lawoi' and Moken as members of the Austronesian or Malayo-Polynesian language family (Sorat 1981:71-72). He shows the relationship between the three languages in the following tree diagram (Sorat 1981:51):

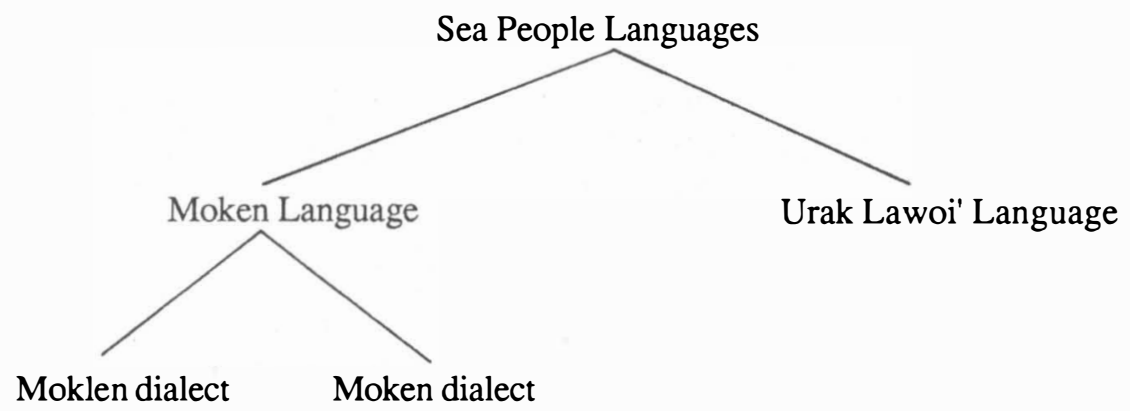

Working on the hypothesis that Moken, Moklen and Urak Lawoi' may share the same protolanguage, Sudarat Leerabhandh (1984) has used phonological comparison to reconstruct the parent 
language, "Proto Orang-Laut". Her study clearly establishes that Moklen-Moken and Urak Lawoi' have a common ancestry in the Austronesian family (Sudarat 1984:196-202). Her tree of the relationship between these three languages is similar to Sorat's tree above.

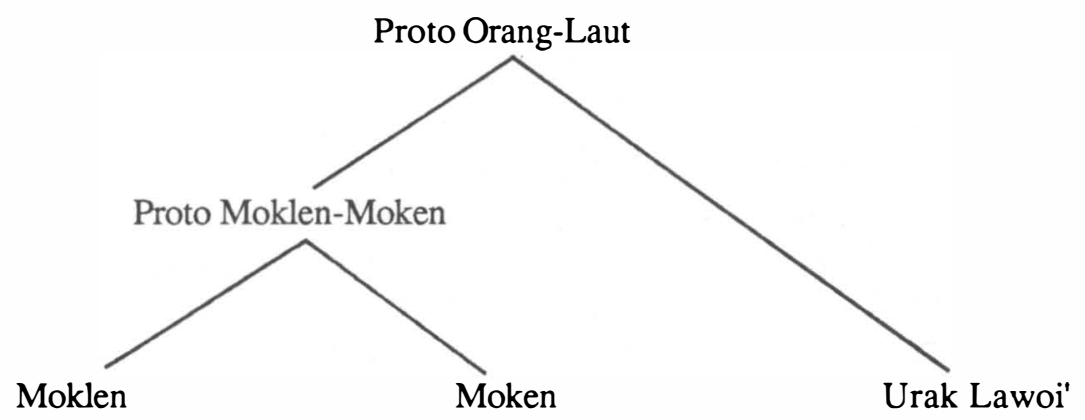

Exploring the possible wider affiliations of Proto Orang-Laut within the Proto West Indonesian (PWI) cluster of the Austronesian family, Sudarat considers that Proto Orang-Laut (POL) may equal the Proto Malayic, with the three languages Moklen, Moken, and Urak Lawoi' being part of the Malayic branch (Sudarat 1984:201-202). She sets out this relationship in the tree diagram below:

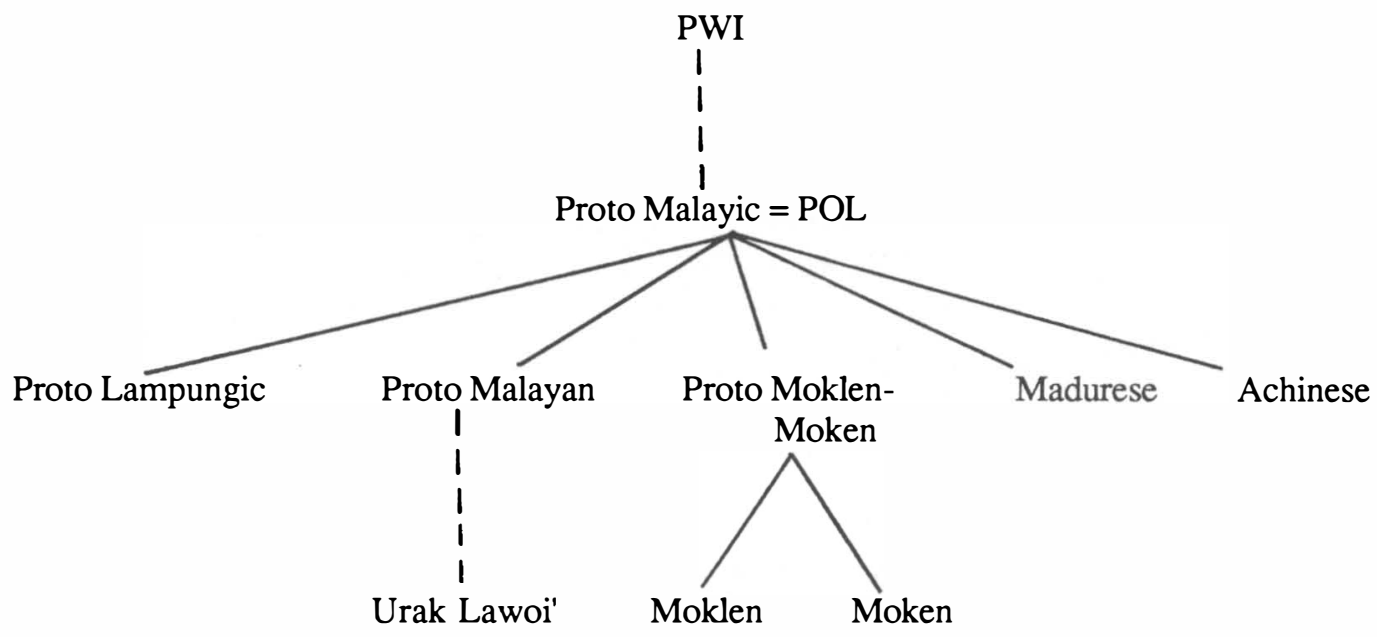

The cognate percentages reported by Sorat (1981:71-72), would seem to favour this possibility, as they indicate that Urak Lawoi' is the same language as Malay; that is, it is within the Proto Malayan Sub-family of Dyen's Proto Malayic Hesion (compare Hogan 1978:16). As the cognate ratio between Moken-Moklen and Malay is only $44.51 \%$ to $45.60 \%$, this would place Moken and Moklen in a similar category to Achinese, which has a percentage of $43.7 \%$ words cognate with Malay. 
As Urak Lawoi' is so closely related to Malay, linguistic descriptions of that language have been consulted. Payne's "Basic syntactic structures in standard Malay" (1970), deals with Malay from the Morphology to the Sentence level, from a descriptive viewpoint. In "The morphology of Malay" (1974), Abdullah Hassan gives a comprehensive survey of the complex morphological structure of Malay. Descriptions of Thai have not proved so relevant, but are referred to when appropriate.

\subsection{Theoretical framework adopted for the study}

The theoretical approach adopted for this study is descriptive, with particular reliance on the tagmemic framework developed by Pike and his colleagues of the Summer Institute of Linguistics. The tagmemic approach is described fully by Elson and Pickett (1962), Longacre (1964), Cook (1976) and Pike and Pike (1977). Briefly it may be described as four steps of procedure.

\subsubsection{Basic data}

Non-elicited text from native-born speakers of the language is recorded as the basic data for the study. The emphasis is on the objective recording of samples of the language as it is actually spoken, but bearing in mind that the informant's performance may not accurately reflect his competence in the language (Chomsky 1977:7). Elicited text is prefaced with the marker \#. Any unacceptable text is prefaced with the marker *.

\subsubsection{Syntactic levels}

The data recorded is analysed in terms of various levels or ranks of grammatical hierarchy. Cook lists the typical levels of grammar as the sentence, clause, phrase, word and morpheme levels (Cook 1969:30). Pike and Pike add higher levels of paragraph, monologue, exchange or conversation (Pike and Pike 1977:4), which are sometimes grouped together as Utterance or Discourse Level. In this work the Phonemic Level has been included, followed by Word Level and Phrase Level. Morpheme Level has been incorporated in Word Level as there is a minimal amount of affixation in this language.

\subsubsection{Tagmemic units}

Tagmemic units are set up for each level in terms of the internal structure of each grammatical unit and its external function, normally at the next higher level. The tagmeme has been defined as "the correlation of a grammatical function, or slot, with the class of mutually substitutable items that fill that slot" (Elson and Pickett 1962:57). So functional slots are filled by items of varying structures. In this paper a similar framework is used for the Phonemic Level, with the phoneme regarded as a functional slot which can be filled by different phonetic structures.

While slots are normally filled by structures from the level immediately below, there are cases of "level skips", where a filler from a lower level construction fills a slot at a level higher than normal. There are instances of "layering", where a slot at one level is filled by a structure from the 
same level. Then there are "loopbacks", here called "embedding" where a slot at a particular level is filled by a structure from a higher level (Cook 1969:31).

\subsubsection{Tagmemic formulae}

Tagmemic formulae are set up with an abbreviation for the functional slot name of a tagmeme followed by a colon, after which there is an abbreviation for the structural filler of that slot. This tagmeme is marked as obligatorily present, as obligatorily absent, or as optional. The abbreviations used have been listed previously. Some examples are as follows:

Normal: $\quad \pm$ Qn:ipn

This is read as an optional Quantifier slot at Phrase Level, filled by an indefinite pronoun; e.g. some.

Level skip: \pm Loc:avl

This is read as an optional Location slot at Clause Level, filled by an adverb of location; e.g. there.

Layering: $\quad \pm$ Mod:PP

This is read as an optional Modifier slot at Phrase Level, filled by a prepositional phrase; e.g. in the village.

Embedding: +Obj:U

This is read as an obligatory Object slot at Clause Level, filled by an utterance; e.g. Come.

\subsection{Methodology and phonemic alphabet}

\subsubsection{Methodology}

A $n$ initial study of the language was commenced in 1967, using a bi-lingual approach. As soon as possible, impromptu narrations from various informants were recorded, so that the analysis would be based on non-elicited texts. The phonemic structure was analysed and an orthography was prepared, using the letters of the Thai alphabet (Hogan 1976). This was tested with native speakers, and proved usable.

A selection of words were entered on computer cards, which were edge-clipped to indicate consonants and vowels and other features. This selection of 135 mono-syllabic words, 1165 bisyllabic words and 125 tri-syllabic words is the basis of the tables of phonemic occurrences in Chapter II. This card system facilitated the extraction of information under different categories (Conrad 1975).

A computer concordance was prepared of forty-six of the non-elicited texts. The total corpus contained 2555 clauses, with some texts only brief and others as long as 230 clauses. This concordance has been invaluable in the analysis of the language. 


\subsubsection{Phonemic alphabet}

The phonemic alphabet used in this study is a modification of the alphabet described in my earlier paper (Hogan 1976). The consonant phonemes are /ph th ch kh p t c k q(?) b d j g h m n

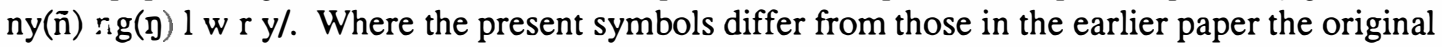
symbols are given in brackets. All of these phonemes except the glottal stop /q/ occur syllableinitially, but /ph th ch kh b j g ny/ do not occur syllable-finally. Details of these phonemes are given in Section 2.1.1.

The vowel phonemes are /i ë (e) ä (ع) e (i) a u o ö (o)/. Details are given in Section 2.1.2. It must be noted that the transition vowel [ə] is now written as /e/.

Where quotations are made from Amon's thesis her text has been written in this phonemic alphabet. Phonetic material uses normal phonetic symbols enclosed in phonetic brackets [ ].

1.4.2.1 The phonemic alphabet, the Thai orthography, and the computer alphabet

It has been necessary to use different symbolisations of the UL phonemes for various purposes. In my original paper (Hogan 1976), I used a phonemic script written in romanised characters. In that paper I also outlined an orthography using letters of the Thai alphabet, with a few modifications for UL phonemes that did not have a direct equivalent in Thai. Subsequently the Thai government stipulated that the use of the Thai alphabet was compulsory for any literature written in a minor language of the country. Some publications in UL have used this orthography with some occasional modifications. Then, when I entered my UL text material into the computer, it was necessary to modify the phonemic representation slightly, to meet the requirements of the computer. It is this computer version of the phonemic alphabet which has been used in this study.

Figures 3 to 6 in the 1976 paper showed the phonemic alphabet and the Thai orthography (1976:295-301). Those figures have now been modified to show the computer alphabet and to write the examples in that alphabet, as set out below.

\section{Syllable-initial consonants}

Fig. 1 (modified from 1976 Fig. 3)

\begin{tabular}{ccclll}
$\begin{array}{c}\text { Phonemic } \\
\text { Script }\end{array}$ & $\begin{array}{c}\text { Computer } \\
\text { Alphabet }\end{array}$ & Orthography & \multicolumn{3}{c}{ Example } \\
ph & ph & พ & /phrerngan/ & พรืองัน & 'kind of fish' \\
th & th & n & /thok/ & โทก & 'bag' \\
ch & ch & ช & /bechi/ & บีชี & 'hate' \\
kh & kh & ค & /khru/ & ครู & 'teacher' \\
p & p & ป & /pi/ & ป & 'go'
\end{tabular}




\begin{tabular}{|c|c|c|c|c|c|}
\hline $\mathrm{t}$ & $\mathrm{t}$ & ต & /tiga/ & ตีฆา & 'three' \\
\hline c & c & $จ$ & $/ \mathrm{ca} /$ & จา & 'older sibling' \\
\hline $\mathrm{k}$ & $\mathrm{k}$ & $n$ & /kita/ & กีตา & 'we (incl)' \\
\hline$?$ & - & อ & /akëq/ & อาเกะ & 'lift' \\
\hline $\mathrm{b}$ & $\mathrm{b}$ & บ & /bini/ & บีนี & 'wife' \\
\hline $\mathrm{d}$ & $\mathrm{d}$ & ด & /diha/ & กีฮา & 'where' \\
\hline j & $\mathrm{j}$ & $\alpha(y)$ & /jadi/ & ดาดี & 'become' \\
\hline $\mathrm{g}$ & $\mathrm{g}$ & ม & /gati/ & ขาตี & 'in place of' \\
\hline s & s & ช & /sungoh/ & ชูโงฮ & 'truly' \\
\hline $\mathrm{h}$ & $\mathrm{h}$ & ช & /hitap/ & ฮีตัต & 'black' \\
\hline $\mathrm{m}$ & $\mathrm{m}$ & ม & /mesiya/ & มีขียา & 'mankind' \\
\hline $\mathrm{n}$ & $\mathrm{n}$ & น & /nam/ & นัม & 'six' \\
\hline$\tilde{\mathrm{n}}$ & ny & ญ & /nya/ & ญา & 'he' \\
\hline פ & $\mathrm{ng}$ & ง & /nganga/ & งางา & 'gaping open' \\
\hline 1 & 1 & ล & /lalu/ & ลาถู & 'pass' \\
\hline $\mathrm{w}$ & $\mathrm{w}$ & 2 & /waqtu/ & วะฑู & 'time' \\
\hline r & $\mathrm{r}$ & $g$ & /rigaq/ & รีมะ & 'catch' \\
\hline & $\mathrm{y}$ & $\boldsymbol{y}$ & $\mathrm{y}$ & กายู & /kayu/ 'wood' \\
\hline
\end{tabular}

Syllable-initially, all of the Thai letters have been used with their normal Thai pronunciation, except for $\langle\boldsymbol{Q}\rangle,\langle\boldsymbol{\nu}\rangle$, and $<$ $\rangle$, which have been used to represent $/ \mathrm{j} /, / \mathrm{g} /$, and $/ \mathrm{ny} /$ respectively. It will be noted that $/ \tilde{n} /$, and $/ \mathrm{n} /$ in the original phonemic alphabet have been changed to /ny/ and /ng/ in the computer alphabet. As described in Section 2.2.1.3.6 the initial glottal stop is not now regarded as phonemic, so it has been omitted from the computer alphabet column. However in the Thai orthography column the consonant $<\mathrm{e}>$ has been left in this position as it occurs syllable-initially in syllables with no initial consonant.

For the phoneme $/ \mathrm{j} /$, the Thai orthography shows $\langle\boldsymbol{\varepsilon}>$ in brackets after $\langle\boldsymbol{a}>$ as for a time this letter was substituted for the normal $<\alpha>$, as being closer to the way many would hear this phoneme. It was found that this caused confusion, and slowed down the reading process, so I reverted to <al>. 


\section{Syllable-final consonants}

Fig. 2 (modified from 1976 Fig. 4)

\begin{tabular}{|c|c|c|c|c|c|}
\hline Phonemic & Computer & Orthography & & Example & \\
\hline $\mathrm{p}$ & $\mathrm{p}$ & บ & /kalap/ & กาตับ & 'pencil' \\
\hline $\mathrm{t}$ & $\mathrm{t}$ & ค & /tuhat/ & ตูปัด & 'god, owner' \\
\hline c & c & จ & /surac/ & ชูรัจ & 'book, writing' \\
\hline $\mathrm{k}$ & $\mathrm{k}$ & $n$ & /barak/ & บารัก & 'goods' \\
\hline $\mathrm{i} ?$ & $\mathrm{iq}$ & $=$ & /dumiq/ & คูมิ & 'little,small' \\
\hline$e^{?}$ & ëq & $1-2$ & /capëq/ & จาเปะ & 'crippled' \\
\hline$\varepsilon^{?}$ & äq & แ-ะ & /langäq/ & ลาแงะ & 'sky' \\
\hline$a^{?}$ & $\mathrm{aq}$ & $-\Sigma$ & /kaq/ & กะ & 'to' \\
\hline $\mathrm{u}$ ? & uq & ; & /lekuq/ & ลีกุ & 'blister' \\
\hline o? & oq & โ-ะ & /likoq/ & ลีโกะ & 'cover up' \\
\hline ? & öq & เ-าะ & /liköq/ & ลีเกาะ & 'bend, curve' \\
\hline $\mathrm{s}$ & $\mathrm{s}$ & ข & /atas/ & อาตัช & 'upon' \\
\hline $\mathrm{h}$ & $\mathrm{h}$ & ฮ & /belëh/ & บีเลฮ & 'can, get' \\
\hline $\mathrm{m}$ & $\mathrm{m}$ & ม & /nam/ & นัม & 'six' \\
\hline $\mathrm{n}$ & $\mathrm{n}$ & น & /jangan/ & ดกงัน & 'don't; with' \\
\hline I & ng & ง & /senang/ & ชันัง & 'comfortable' \\
\hline 1 & 1 & $\dot{\varepsilon}($ (อ) & /ajal/ & อาณัย & 'teach' \\
\hline aw & aw & $1-7$ & /kaw/ & เกา & 'you (sg)' \\
\hline$\varepsilon w$ & äw & แแ-ว & /betäw/ & บีแตว & 'kind of shark' \\
\hline ay & ay & -ย & /ramay/ & รามัย & 'fun' \\
\hline $\mathrm{y}$ & öy & -อย & /höy/ & ซอย & 'have not' \\
\hline
\end{tabular}

/c/ does not occur syllable-finally in Thai; where $<\nabla>$ occurs in this position it is pronounced (t). Similarly $/ \mathrm{s} /$ and $/ \mathrm{h} /$ do not occur syllable-finally in Thai. In listing the final glottal, it is necessary to show the vowel which it follows, so as to show all the possible combinations. The same applies to syllables ending with $/ \mathrm{w} /$ and $/ y /$. Syllables ending with final $<\Omega>$ in Thai are pronounced with a final (n). To avoid this, UL syllables ending with $/ \mathrm{l} /$ were originally written with a final $\langle-D\rangle$, as shown in brackets under the orthography. Later this was replaced with a final $\langle-\dot{\xi}\rangle$. This simplifies matters for speakers of PYP who pronounce this phoneme as $/ y /$. 
For the speaker of POP, the circle above the $\langle\dot{\varphi}>$ signals that the final consonant is $/ 1 /$ not $/ \mathrm{y} /$. The speaker of the Adang dialect must read every syllable marked in this way as a final/er/.

Vowels in open syllables

Fig. 3 (modified from 1976 Fig. 5)

\begin{tabular}{|c|c|c|c|c|c|}
\hline $\begin{array}{l}\text { Phonemic } \\
\text { Script }\end{array}$ & $\begin{array}{l}\text { Computer } \\
\text { Alphabet }\end{array}$ & Orthography & & Example & \\
\hline i & i & $=$ & /ini/ & อีนี & 'this' \\
\hline $\mathrm{e}$ & $\ddot{\mathrm{e}}$ & $1-$ & /ayë/ & อาเย & 'water' \\
\hline$\varepsilon$ & $\ddot{a}$ & แ- & /cä/ & แจ & 'grandfather' \\
\hline$i$ & $\mathrm{e}$ & $=$ & /senang/ & ชันัง & 'comfortable' \\
\hline a. & $\mathrm{a}$ & -7 & /raga/ & ราขา & 'basket' \\
\hline $\mathrm{u}$ & $\mathrm{u}$ & $\bar{v}$ & /tungu/ & ตูง & 'wait, watch' \\
\hline o & o & T- & /nori/ & โนรี & 'lorry' \\
\hline o & $\ddot{o}$ & -0 & /böya/ & บอยา & 'stempiece' \\
\hline
\end{tabular}

Vowels in closed syllables

Fig. 4 (modified from 1976 Fig. 6)

\begin{tabular}{|c|c|c|c|c|c|}
\hline $\begin{array}{l}\text { Phonemic } \\
\text { Script }\end{array}$ & $\begin{array}{l}\text { Computer } \\
\text { Alphabet }\end{array}$ & $\begin{array}{l}\text { Ortho- } \\
\text { graphy }\end{array}$ & $\begin{array}{l}\text { Normal } \\
\text { Syllable }\end{array}$ & $\begin{array}{l}\text { Syllable with } \\
\text { finalglottal }\end{array}$ & Meaning \\
\hline \multirow[t]{2}{*}{$\mathrm{i}$} & \multirow[t]{2}{*}{ i } & $=$ & \multirow[t]{2}{*}{ /asik/ อาชิก } & & 'other' \\
\hline & & $=$ & & /bajiq/ บาณิ & 'good' \\
\hline \multirow[t]{2}{*}{ e } & \multirow[t]{2}{*}{$\ddot{\mathrm{e}}$} & $1--$ & \multirow[t]{2}{*}{ /angën/ อาเงน } & & 'wind' \\
\hline & & 1-ะ & & /capëq/ จาเปะ & 'crippled' \\
\hline \multirow[t]{2}{*}{$\varepsilon$} & \multirow[t]{2}{*}{ ä } & แ- & \multicolumn{2}{|l|}{ /betäw/ บีแตว } & $\begin{array}{l}\text { 'type of } \\
\text { shark' }\end{array}$ \\
\hline & & แ-ะ & & /langäq/ลาแงะ & 'sky' \\
\hline \multirow[t]{4}{*}{$\dot{i}$} & \multirow[t]{4}{*}{ er } & - & \multicolumn{2}{|c|}{ (in non-final syllable) } & \\
\hline & & & /permelaw/ ปี & อมีเลา & 'word' \\
\hline & & & /krerja/ ns & รือan & 'work' \\
\hline & & $1-0$ & \multicolumn{2}{|c|}{ (in final syllable) } & 'querv' \\
\hline
\end{tabular}




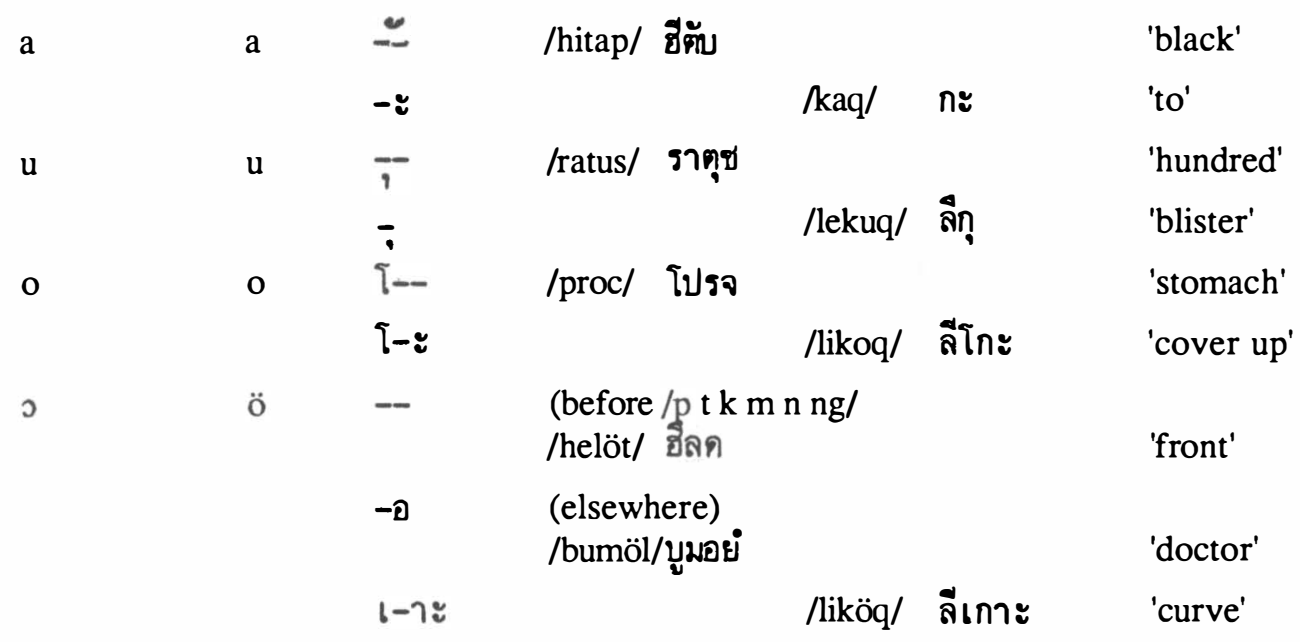

Figures 3 and 4 give details of the vowels in open and closed syllables with a separate column for syllables ending with a glottal, because of the way these are shown in the Thai alphabet. UL has not the phonemic contrast between short and long vowels which Thai has, but the vowel in a closed syllable is shorter than that in an open syllable. Therefore UL vowels in closed syllables have been written as short Thai vowels. Recently the vowel shortener $\langle\approx>>$ used with vowels $<$ ! $-\mathfrak{u}$ - \{- -0 > has been discontinued as unnecessary for UL, but the UL vowels $/ \mathrm{i}$ a $\mathrm{u} /$ are still written with theshort vowel forms $<---\boldsymbol{- \varepsilon}---->$ in closed syllables.

The phoneme listed as / $/ \mathrm{z} /$ in the earlier paper is now written /e/. It occurs as the transition vowel in pre-syllables and before $/ \mathrm{r} /$ in minor and major syllables, and in some prefixes with the potential for stress. Phonemically, [əə] is interpreted as /er/ as explained in Section 2.2.1.3.12. Therefore the /e/ in pre-syllables is listed in Figure 3, as being in an open syllable, while /er/ is listed in Figure 4 for closed syllables, with the final /r/ specified, as /e/ cannot occur with any other final consonant. In non-final syllables $\langle-\vec{b}\rangle$ is used in closed syllables and $\langle=>$ in open syllables. Words such as /krerja/ 'work' which have phonetic variations as described in the reference above, have sometimes been written with <-รือ $>$ and sometimes with < - 2 - > e.g. $<$ กรื่อณา $>$ or $<$ กื่อฒา $>$. These spellings have now been standardised as $<-$ รื่อ $>$

In recent years, the inherent $<0>$ before $/ \mathrm{p} \mathrm{t} \mathrm{k} \mathrm{m} \mathrm{n} \mathrm{ng} / \mathrm{has}$ been interpreted as /ö/, not /o/ as before. The modification of Figure 4 shows the detail of this.

In writing Urak Lawoi', tone, stress and intonation are not shown. The Thai method of writing without any space between words is not followed, as difficulties would be caused by the way in which UL final consonants differ from those in Thai. Brief spaces between words assist in identifying word boundaries, while a longer space is used to signal the end of a phrase or clause. 


\section{CHAPTER 2}

PHONEME LEVEL

This chapter gives a preliminary outline of the structure of the syllable and word, describes the phonetic structures of the various phonemes, and finally shows how the phonemes function in the construction of syllables and words. ${ }^{1}$

Previously I have briefly described the phonemes of the Phuket Old People's (POP) dialect of Urak Lawoi' (Hogan 1976:283-295), while Amon has described the phonemes of the Adang (AD) or Southern dialect (Amon 1979). Section 5 of this chapter will comment on some of the relationships between the three dialects of Urak Lawoi'.

\subsection{Outline of the syllable and word}

\subsubsection{Syllable structure}

Syllables may be divided into three types: major syllables, minor syllables, and pre-syllables. These types are identified by their place of occurrence in the word, and the vowels and final consonants which occur in them.

The major syllable is obligatory and final in every word, so that a mono-syllabic word has a major syllable only. The major syllable may have any consonant or a consonant cluster initially. Any vowel may occur but the vowel /e/ occurs only with a final $/ r$. Any of the final consonants listed in Section 1.4.2. may occur, or there may be no final consonant.

The minor syllable and pre-syllable are distinguished from the major syllable by being optional and non-final in any word. Both may have a consonant cluster initially but it is not common in a minor syllable and in my data only occurs once in a pre-syllable. These two types differ on three points:

a. The minor syllable can commence with any consonant or zero but the pre-syllable never occurs without an initial consonant.

b. The minor syllable has all vowels, but with /i a u/ predominating and /e/ occurring only with final $/ r /$, while the pre-syllable has only the vocalic transition $/ e /$.

c. The minor syllable has a limited occurrence of final consonants with only seven consonants appearing in the data. The pre-syllable never has a final consonant. 
The stresses that may occur on these syllable types are described in Section 2.3.3. while other points are described elsewhere in Section 2.3.

The structure of the major syllable is $(\mathrm{C}(\mathrm{C})) \mathrm{V}$ or $(\mathrm{C}(\mathrm{C})) \mathrm{VC}$. That of the minor syllable is $(\mathrm{C}(\mathrm{C})) \mathrm{V}$ or $\mathrm{CVC}$, and the pre-syllable $\mathrm{C}(\mathrm{C}) \mathrm{V}$.

Major syllable:

$\begin{array}{lll}\text { CV } & \text { /pi/ } & \text { 'to go' } \\ \text { CVC } & \text { /caq/ } & \text { 'that ...' } \\ \text { CCV } & \text { /bri/ } & \text { 'to give' } \\ \text { CCVC } & \text { /proc/ } & \text { 'stomach' } \\ \text { V } & \text { /ba.u/ } & \text { 'smell' } \\ \text { VC } & \text { /ët } & \text { 'mother' }\end{array}$

Minor syllable (+ major syllable):

$\begin{array}{lll}\text { CV } & \text { /ka.nyaw/ } & \text { 'you' (pl) } \\ \text { CVC } & \text { /waq.tu/ } & \text { 'time' } \\ \text { CCV } & \text { /pra.hu/ } & \text { 'boat' } \\ \text { V } & \text { /a.da/ } & \text { 'to have' }\end{array}$

Pre-syllable (+ major syllable):

$\begin{array}{lll}\text { CV } & \text { /te.bak/ } & \text { 'to chop down' } \\ \text { CCV } & \text { /phre.ngan/ } & \text { 'swordfish' }\end{array}$

\subsubsection{Word structure}

UL words may have one, two or three syllables. Apparent exceptions are either compound words or reduplications. Every word must have an obligatory major syllable, and may optionally have one or two syllables preceding the major syllable, which may be either minor syllables or pre-syllables, in various combinations. Some typical words follow:

$\begin{array}{lll}\text { Major syllable only } & \text { /caq/ } & \text { 'that ...' } \\ \text { Minor + major } & \text { /ma.soq/ } & \text { 'enter' } \\ \text { Pre-syllable + major } & \text { /me.law/ } & \text { 'speak' } \\ \text { Pre- + pre- + major } & \text { /me.be.lëh/ } & \text { 'gets' } \\ \text { Pre- + minor + major } & \text { /te.la.ga/ } & \text { 'well' }\end{array}$




\subsection{Phonetic structure of the phoneme}

\subsubsection{Consonant phonemes}

\subsubsection{Phonemic chart of the consonants}

The 23 consonant phonemes of the POP dialect of Urak Lawoi' are set out in Table 2.1.

Table 2-1. Urak Lawoi' consonant phonemes

\begin{tabular}{|l|c|c|c|c|c|}
\hline & Labial & Alveolar & Alveo-palatal & Velar & Glottal \\
\hline $\begin{array}{l}\text { Stops } \\
\quad \text { Voiceless } \\
\text { aspirated }\end{array}$ & $\mathrm{ph}$ & $\mathrm{th}$ & $\mathrm{ch}$ & $\mathrm{kh}$ & \\
$\quad \begin{array}{c}\text { Voicless } \\
\text { unaspirated }\end{array}$ & $\mathrm{p}$ & $\mathrm{t}$ & $\mathrm{c}$ & $\mathrm{k}$ & $\mathrm{q}$ \\
$\quad \begin{array}{c}\text { Voiced } \\
\text { Fricatives }\end{array}$ & $\mathrm{b}$ & $\mathrm{d}$ & $\mathrm{j}$ & $\mathrm{g}$ & $\mathrm{h}$ \\
$\begin{array}{l}\text { Nasals } \\
\text { Laterals } \\
\text { Semi-vowels }\end{array}$ & $\mathrm{m}$ & $\mathrm{n}$ & $\mathrm{s}$ & $\mathrm{ng}$ & \\
\hline
\end{tabular}

The glottal stop is written /q/. Digraphs /ph th ch kh/are used for the voiceless aspirated stops, and digraphs /ny ng/ are used for the alveo-palatal and velar nasals.

\subsubsection{Frequency of occurrence of consonant phonemes}

This is as set out in Table 2-2, showing the number of occurrences of each consonant syllableinitially and syllable-finally both in initial and in final syllables. As explained in Section 2.1.1. the final syllables are major syllables and the initial syllables include both minor syllables and presyllables.

It will be noted that all consonants except/q/occur syllable-initially, but only the phonemes/p k $\mathrm{q} \mathrm{m} \mathrm{n} \mathrm{ng}$ / appear finally in initial syllables, while / $\mathrm{p} \mathrm{c} \mathrm{k} \mathrm{q} \mathrm{m} \mathrm{n} \mathrm{ng} \mathrm{h} \mathrm{l} \mathrm{r} \mathrm{w} \mathrm{y/appear} \mathrm{finally} \mathrm{in} \mathrm{the}$ final syllable. 
Table 2-2. Frequency of occurrence of consonant phonemes

\begin{tabular}{|c|c|c|c|c|}
\hline \multirow[t]{2}{*}{ Phoneme } & \multicolumn{2}{|c|}{ Initial syllable } & \multicolumn{2}{|c|}{ Final syllable } \\
\hline & initially & finally & initially & finally \\
\hline $\mathrm{p}$ & 92 & 1 & 109 & 41 \\
\hline $\mathrm{t}$ & 144 & - & 122 & 73 \\
\hline c & 29 & - & 41 & 103 \\
\hline $\mathrm{k}$ & 116 & 4 & 104 & 155 \\
\hline $\mathrm{q}$ & . & 15 & . & 248 \\
\hline zero & 93 & - & 16 & - \\
\hline ph & 5 & - & 2 & - \\
\hline th & 2 & - & 7 & - \\
\hline $\mathrm{ch}$ & 2 & - & 4 & - \\
\hline $\mathrm{kh}$ & 2 & - & 6 & - \\
\hline b & 141 & - & 75 & - \\
\hline $\mathrm{d}$ & 43 & - & 66 & - \\
\hline $\mathrm{j}$ & 37 & - & 34 & - \\
\hline $\mathrm{g}$ & 53 & - & 39 & - \\
\hline $\mathrm{m}$ & 65 & 2 & 92 & 10 \\
\hline $\mathrm{n}$ & 26 & 3 & 80 & 71 \\
\hline ny & 13 & - & 34 & - \\
\hline ng & 13 & 3 & 58 & 31 \\
\hline s & 110 & - & 79 & 50 \\
\hline $\mathrm{h}$ & 25 & - & 37 & 108 \\
\hline 1 & 89 & - & 117 & 64 \\
\hline $\mathrm{r}$ & 60 & 26 & 86 & 5 \\
\hline w & 2 & - & 50 & 24 \\
\hline $\mathrm{y}$ & 3 & - & 42 & 37 \\
\hline Totals & 1165 & 54 & 1300 & 1020 \\
\hline
\end{tabular}




\subsubsection{Problems of interpretation}

The consonant phonemes where there are problems of interpretation are as follows:

2.2.1.3.1 Consonant clusters [pr tr $\mathrm{cr}$ kr phr $\mathrm{khr}$ br $\mathrm{dr}$ jr $\mathrm{gr} \mathbf{m r} \mathrm{sr}$ ]: Consonant clusters of which the second member is [r] are non-suspicious clusters which have been interpreted as two phonemic segments.

There are not many words with the / $\mathrm{br} /$ cluster, but they must be distinguished from words commencing with the prefix /ber-/, which sometimes omits the /e/ (see 2.5.1 and 3.1.2.4).

Word with /br/ cluster:

/bri/ 'to give'

Words with /ber-/ prefix:

$\begin{array}{lll}\text { /ingac/ 'to think' } & \text { [beringac } \sim \text { bringac] } & \text { 'thinking' } \\ \text { /anaq/ 'child' } & \text { [beranaq } \sim \text { branaq] } & \text { 'give birth to' }\end{array}$

2.2.1.3.2 Aspirated stops [ph th ch $\mathbf{k h}$ ]: The number of words involved is small. The data provides 30 words of this type, 15 of which are Thai loan-words, and 5 are proper names. The Thai language has the phonemes $<\mathrm{ph}$ th $\mathrm{ch} \mathrm{kh}>$, thus exerting pressure on Urak Lawoi' to conform to the dominant language of the country.

The POP data includes four words with the initial consonant cluster [phr], and two with [khr], as listed below:

\begin{tabular}{|c|c|}
\hline 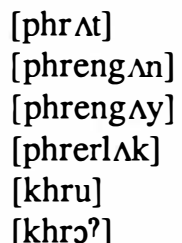 & $\begin{array}{l}\text { 'very' } \\
\text { 'swordfish' } \\
\text { 'Hai Island' } \\
\text { 'stingray' } \\
\text { 'teacher' (TLW) } \\
\text { 'fate'(TLW) }\end{array}$ \\
\hline
\end{tabular}

The two words with [khr] are Thai loan words, but the others are genuine Urak Lawoi' words. If [ph] is interpreted as a consonant cluster CC, this would make [phr] a consonant cluster CCC. As there are no non-suspicious occurrences of such clusters in Urak Lawoi' these aspirated voiceless stops have been interpreted as the phonemes /ph th $\mathrm{ch} \mathrm{kh} /$.

2.2.1.3.3 Consonant clusters [pl tl $\mathrm{cl} \mathrm{kl} \mathrm{bl} \mathrm{gl} \mathrm{sl} \mathrm{ml]:} \mathrm{Clusters} \mathrm{of} \mathrm{which} \mathrm{the} \mathrm{second}$ member is [1] are non-suspicious consonant clusters and have been interpreted as two phonemic segments. Many POP speakers pronounce such words with a vocalic transition between the two consonants so they are not written here as a consonant cluster, as Amon has done in the Adang dialect (see 2.5.1). Three words with the cluster /pl/ never include the transition: /plihac/ 'to be revealed', /plepas/ 'to free', /plekac/ 'to be kindled'. This is a morpho-phonemic variation as described in Section 3.1.2.4. 
2.2.1.3.4 Consonant clusters [hl $\mathrm{hm} h \mathrm{hn}$ hny]: These clusters must be regarded as suspicious clusters which could be either two phonemic segments or a pre-aspirated nasal or lateral. There are not many words with these clusters, with only the following words noted in POP:

$\begin{array}{ll}\text { /helak/ } & \text { 'eagle, hawk' } \\ \text { /helöt/ } & \text { 'front' } \\ \text { /hempas/ } & \text { 'throw down violently' } \\ \text { /hentaq/ } & \text { 'begin' } \\ \text { /henus/ } & \text { 'cuttlefish' } \\ \text { /paq-henya/ } & \text { 'evening' }\end{array}$

Some speakers pronounce these words with a light transition vowel /e/, giving an initial /he-/ syllable. Therefore these clusters have been interpreted as cases where an initial pre-syllable /he-/ has light to zero transition.

2.2.1.3.5 Syllable-final [Viq]: Urak Lawoi' has final syllables ending with [-aiq -uiq -oiq -oiq]. These cannot be interpreted as $-\mathrm{VVq}$ because the language has no non-suspicious vowel clusters. Where the cognate Malay word is known it ends with <-at -ut -ot >:

$\begin{array}{ccl}\mathrm{UL}-\text { [sur } \Delta \mathrm{iq}] & \text { Malay - surat } & \text { 'book' } \\ \text { [terkejuiq] } & \text { terkejut } & \text { 'startled' } \\ \text { [pruiq] } & \text { perut } & \text { 'stomach' } \\ \text { [roiq] } & - & \text { 'reach' }\end{array}$

In these words it seems that [-iq] acts as a single phonetically complex phoneme. It cannot be interpreted as final $/ t /$ as UL uses this final where the cognate Malay word has $<n>$; e.g. Malay $<$ jalan > becomes UL /jalat/ 'path, way'. It has been interpreted as the syllable-final allophone of /c/, which otherwise does not occur syllable-finally. Section 2.2.1.4.1. shows how UL final /t/ contrasts with final /c/.

This final /c/ does not occur following the front vowels /i ë ä/. Of the Urak Lawoi' words ending with a front vowel plus a glottal, some Malay cognates end with a front vowel plus $<\mathrm{k}>$ and some with a front vowel plus $<t>$ :

$\begin{array}{ccc}\text { UL - [baliq] } & \text { Malay - balik } & \text { 'return' } \\ \text { [dikiq] } & \text { sedikit } & \text { 'small' } \\ \text { [capëq] } & \text { capik } & \text { 'crippled' }\end{array}$

2.2.1.3.6 The glottal stop [q]: The syllable-final glottal stop occurs word-finally in 248 words in the data. In this position it contrasts with 155 occurrences of final $/ \mathrm{k} /$ as illustrated in minimal pairs such as /sayak/ 'love', /sayaq/ 'wing'. There are only 15 occurrences of it finally in minor syllables, reflecting the scarcity of final consonants in that position.

Syllable-initially there are no occurrences of the glottal stop in pre-syllables, 93 in minor syllables and 16 in major syllables. Where it does occur there is no case of phonemic contrast with two words distinguished from one another by the presence or absence of an initial glottal. This scarcity of the glottal initially in major syllables compares strikingly with the frequency of other phonemes, with the exception of the aspirated stops. It is apparent that the glottal only occurs in this position when the previous syllable ends with a vowel or a glottal. The pronunciation word-initially is not consistent, with some words having a strong initial glottal, and 
others having only a slight glottal constriction, or no glottal at all. The glottal is clearly present following the final vowel of a preceding syllable.

$\begin{array}{ll}\text { No initial glottal: } & \text { [aye] 'water' } \\ \text { Light initial glottal: } & \text { [qat } \wedge \text { ih] 'upon' } \\ \text { Heavy initial glottal: } & \text { [qake?] 'lift' } \\ \text { Following a vowel: } & \text { [mata.qari] 'sun' }\end{array}$

Furthermore, in Section 3.1.2.4.1 it is pointed out that the initial glottal does not operate in the same way as the other initial stops as far as morphophonemic variation is concemed. When the initial stops are prefixed by /meN-/ or /peN-/, those stops change to a nasal consonant at the same point of articulation. The fact that this does not happen with an initial glottal is a strong indication that the glottal is not phonemic word-initially.

There is no clear evidence that [q] should be regarded as phonemic in any syllable-initial position. In my earlier paper, the cases where glottal was not present were regarded as cases of its deletion. The question merits further study, but in this work the glottal stop will not be written syllable-initially. The case of initial glottals in major syllables is covered by saying that, where a syllable ending with a vowel is followed by a syllable commencing with a vowel, there is a non-phonemic glottal stop at the commencement of the second syllable. If this glottal needs symbolisation, a hyphen is employed to show that it is not a phonemic glottal: i.e. not /meqoc/ 'to praise', but /me-oc/. This will reflect the usage of Malay where the initial glottal is not regarded as phonemic and will simplify the comparison of words in this study with Malay words. ${ }^{2}$

2.2.1.3.7 Voiced alveo-palatal stop $[j]^{3}$ The voiced alveo-palatal stop [j] occurs only syllable-initially. There is some fluctuation in the pronunciation of this phoneme with Phuket Young People (PYP) speakers favouring [y], and POP speakers favouring [j], but sometimes using [y]: e.g. [jalat yalat] 'path, way'. It is considered that many speakers have been influenced by the pressure of Thai, which has no [j] phoneme, with Thai speakers normally pronouncing the English 'John' as <yoon>. The following cases of contrast in analogous situations show typical cases of contrast between [j] and [y].

$\begin{array}{ll}\text { [baju] 'shirt' } & \text { [kayu] 'wood' } \\ \text { [bajiq] 'good' } & \text { [aye] 'water' } \\ \text { [aj } \Lambda \text { l] 'teach' } & \text { [lay } \Lambda \text { l] 'sail' }\end{array}$

Therefore this stop has been interpreted as the phoneme $/ j /$, with free fluctuation $[j \sim y]$.

2.2.1.3.8 Syllable-final [Vih]: Syllable-final [Vih] occurs in the combinations [-aih -uih -oih - oih], contrasting with syllables ending in [-ah -uh -oh -oh]. Here too, the absence of any non-suspicious vowel-clusters forbids the interpretation of these as - VVh. Malay words cognate to the first group end with <-as -us -os>, while those cognate to the second group end with <-ah -uh -oh>:

$\begin{array}{ccc}\text { UL - [at } \wedge \text { ih] } & \text { Malay - atas } & \text { 'upon' } \\ \text { [ratuih] } & \text { ratus } & \text { 'hundred' } \\ \text { [kremoih] } & \text { cemuas } & \text { 'dirty' } \\ \text { UL - [pat } \wedge \text { h] } & \text { Malay - patah } & \text { 'break' } \\ \text { [tedoh] } & \text { tedoh } & \text { 'calm' } \\ \text { [bunoh] } & \text { bunoh } & \text { 'kill' }\end{array}$


Syllable-final [-ih] has therefore been interpreted as a single phonetically complex phoneme, and as being the syllable-final allophone of /s/, which otherwise does not occur syllable-finally.

As with final /c/, this final /s/ does not occur after the front vowels /i ë ä/. Words with front vowels which would be expected to end with $/ \mathrm{s} /$ instead end with $/ \mathrm{h} /$. Urak Lawoi' words ending with a front vowel followed by $/ \mathrm{h} /$ have Malay cognates, some of which end with a front vowel followed by $\langle\mathrm{h}\rangle$, and some with a front vowel followed by $<\mathrm{s}\rangle$ :

$\begin{array}{rrr}\text { UL - /tulëh/ } & \text { Malay - tulis } & \text { 'write' } \\ \text { /lebëh/ } & \text { lebeh } & \text { 'more' } \\ \text { /jenäh/ } & \text { jenis } & \text { 'kind' }\end{array}$

2.2.1.3.9 Alveo-palatal nasal [ny]: The alveo-palatal nasal [ny] occurs syllable-initially both at the beginning and in the middle of a word, and there are no consonant clusters having /y/ as the second member. This nasal has therefore been interpreted as a single phoneme /ny/; e.g. /nyawa/'body'.

2.2.1.3.10 Lateral [1]: In the POP dialect [1] is alveolar syllable-initially and syllable-finally after [i e]. After [ $\varepsilon$ a u o o] it is blade-palatal; e.g. [lihel] 'neck', [bumol] 'doctor'.

2.2.1.3.11 Semi-vowel [r]: Alveolar [r] occurs syllable-initially, varying from a retroflexed vocoid to a slight flap. It also occurs as the second member of consonant clusters. These clusters have been interpreted as clusters of two phonemes; e.g. /prahu/ 'boat', /brapa/ 'how many' (Section 2.2.1.3.1). It also occurs as a retroflexed vocoid after [ə] as described in the next sub-section.

2.2.1.3.12 Vocoid cluster [əə]: Phonetically this cluster is a lengthened [ə]. However, in this environment there is phonetic overlapping of the phonemes so that phonemically the first mora of the cluster is interpreted as the vowel /e/, while the second mora is interpreted as the consonant $/ r /$. In POP this cluster occurs often in penultimate syllables, with only five words having it in the final syllable (Section 2.2.2.3.2). It also occurs in prefix syllables /ber-/,/ter-/ and /per-/, which have the option for a secondary stress (Section 3.1.2.1 and 3.1.2.2). When it occurs in the penultimate syllable, that syllable bears the major word stress and the vowel cluster fluctuates phonetically between the allophones $[r \sim$ re $\sim$ er]. Some typical POP words are listed below with cognate Malay words and English glosses. They all begin with a consonant cluster with $/ \mathrm{r} /$ as the second member of the cluster.

$\begin{array}{llllll}\text { UL: } & \text { Malay: } & \text { Gloss: } & \text { UL: } & \text { Malay: } & \text { Gloss: } \\ \text { prerlëh } & \text { Perlis } & \text { Perlis } & \text { prerciq } & \text { percit } & \text { 'sprinkle' } \\ \text { trerbëq } & \text { terbit } & \text { 'depart' } & \text { prerdu } & \text { perdu } & \text { 'base of tree' } \\ \text { trerbak } & \text { terbang } & \text { 'to fly' } & \text { brerkäw } & \text { berengau } & \text { 'scream' } \\ \text { crermën } & \text { cermin } & \text { 'glass' } & \text { jrermak } & \text { menyeberang } & \text { 'cross over' } \\ \text { crerta } & \text { cerita } & \text { 'fable' } & \text { grerlik } & \text { giling } & \text { 'roll along' } \\ \text { krercac } & & \text { 'crowded' } & \text { phrerlak } & & \text { 'stingray' } \\ \text { krernam } & & \text { 'rabbit' } & \text { mrerpu } & & \text { 'Crab Island' } \\ \text { krermös } & \text { cemuas } & \text { 'dirty' } & \text { mrerka } & & \text { 'seal' } \\ \text { krertas } & \text { kertas } & \text { 'paper' } & \text { srerbak } & \text { seberang } & \text { 'other shore' }\end{array}$




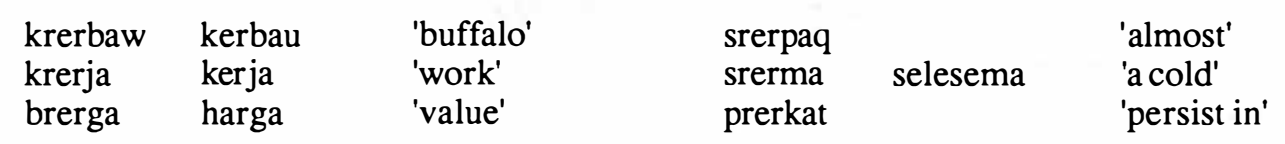

This [əə] is interpreted phonemically as /er/ because (1) there is no long/short vowel contrast elsewhere in this language, (2) it fits the normal CV patterns, (3) it accounts for otherwise strange stress patterns. This is the same interpretation that has been generally accepted for the similar phenomenon in Malay. It should be noted that /e/ occurs in no other closed syllables in UL.

2.2.1.3.13 Semi-vowels [ $w$ y]: Syllable-initially these are definitely consonant phonemes. Syllable-finally they occur as the second member of a vocoid cluster. As there are no nonsuspicious vowel clusters, syllable-final [ $w$ y] have been interpreted as being consonant phonemes: /kanyaw/ '2nd person pronoun', /suray/ 'comb'.

\subsubsection{Consonantal descriptions and contrasts}

The consonants and the contrasts between them are as set out below:

2.2.1.4.1 Stops: The stops and their major phonetic characteristics can be seen in Table 2-1. All except /q/ occur syllable-initially, but only the voiceless unaspirated stops /p t c k q/ occur syllable-finally. In this position they are unreleased.

When /c/ occurs syllable-finally it has the allophone [-iq] (see 2.2.1.3.5.): /surac/ [sur $\Lambda$ iq] 'a book'. After a front vowel the velar unaspirated stop $/ \mathrm{k} /$ is sometimes pronounced as an affricated stop [kx] at the same point of articulation: /kamëk/ [kamekx] 'a sheep'.

When the bilabial stops /p b/ occur initially in a syllable with a back vowel followed by the stop /c/ the allophones [pw bw] may appear: /sipoc/ [sipwoiq] 'shell', /seboc/ [sebwoiq] 'to utter'.

There are two words /hempas/ 'to throw down' and /hentaq/ 'to begin' where a medial stop is pre-nasalised. Possibly this is a pre-nasalised allophone of $/ \mathrm{p} /$ and $/ \mathrm{t} /$ following $/ \mathrm{he}-/$, but the evidence is slight.

The voiceless unaspirated stops contrast syllable-initially and finally:

$\begin{array}{lllll}\text { /p/ } & \text { /paq/ } & \text { 'father' } & \text { /dalap/ } & \text { 'deep' } \\ \text { /t/ } & \text { /taq/ } & \text { 'after' } & \text { /jalat/ } & \text { 'path, way' } \\ \text { /c/ } & \text { /caq/ } & \text { 'that ...' } & \text { /lihac/ } & \text { 'see' } \\ \text { /k/ } & \text { /kaq/ } & \text { 'to' } & \text { /hilak/ } & \text { 'lost' } \\ & & & \text { /graq/ } & \text { 'arouse' }\end{array}$

The voiced stops contrast syllable-initially:

$\begin{array}{lll}\text { /b/ } & \text { /bumöl/ } & \text { 'doctor' } \\ \text { /d/ } & \text { /deniya/ } & \text { 'world' } \\ \text { /j/ } & \text { /jalat/ } & \text { 'road' } \\ \text { /g/ } & \text { /gati/ } & \text { 'in place of' }\end{array}$

The voiceless aspirated stops contrast syllable-initially:
/ph/
/phrengan/
'a kind of fish'
/th/
/bethöl/
'front room' 
$\begin{array}{lll}\text { /ch/ } & \text { /bechi/ } & \text { 'hate' } \\ \text { /kh/ } & \text { /khru/ } & \text { 'teacher' (TLW) }\end{array}$

Other contrasts between the stops are as follows:

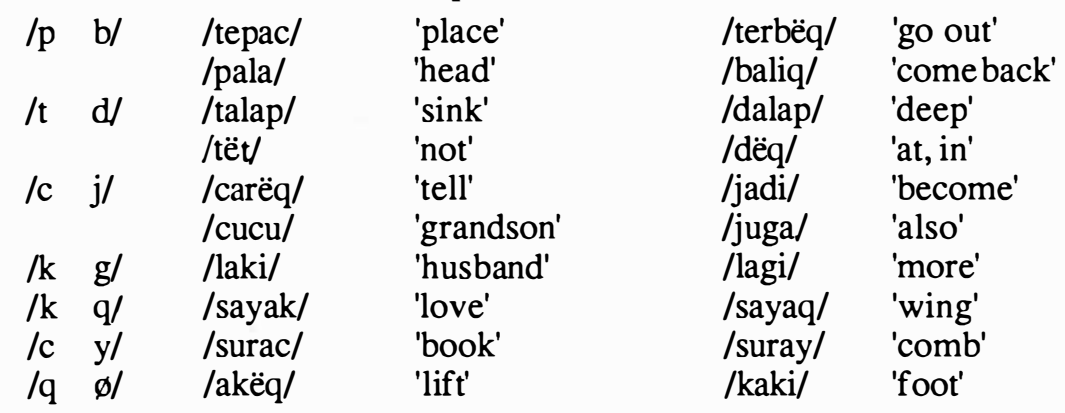

2.2.1.4.2 Fricatives: Syllable-initially the voiceless fricative /s/ varies between lamino-alveolar [s] and the lamino-alveo-palatal allophone [sy] (Malmberg 1963:49-50). Syllable-finally it has the allophone [ih] (see 2.2.1.3.8). The glottal fricative / h/ occurs both syllable-initially and finally.

\begin{tabular}{|c|c|c|c|c|}
\hline /s/ & /sapa/ & 'who?' & /atas/ & 'upon' . \\
\hline $\mathrm{h} /$ & /hapa/ & 'anything' & /patah/ & 'break' \\
\hline
\end{tabular}

2.2.1.4.3 Nasals: The nasals /m n ny ng/ all occur syllable-initially, but only /m n ng/ occur syllable-finally:

$\begin{array}{lllll}\text { /m/ } & \text { /mati/ } & \text { 'die' } & \text { /nam/ } & \text { 'six' } \\ \text { /n/ } & \text { /nati/ } & \text { 'wait' } & \text { /jangan/ } & \text { 'don't' } \\ \text { /ny/ } & \text { /nyawa/ } & \text { 'body' } & & \\ \text { /ng/ } & \text { /nganga/ } & \text { 'gaping' } & \text { /senang/ } & \text { 'contented' }\end{array}$

2.2.1.4.4 Laterals and semi-vowels: / w y/ occur both syllable-initially and finally (see Section 2.2.1.3.13). In some environments / w/ may be nasalised as described in Section 2.3.5, but this is not phonemic. The characteristics of $/ \mathrm{l} /$ and $/ \mathrm{r} /$ are discussed in Sections 2.2.1.3.10 and 2.2.1.3.11 respectively.

$\begin{array}{lllll}\text { /w/ } & \text { /bawa/ } & \text { 'carry' } & \text { /nimaw/ } & \text { 'construct' } \\ \text { /y/ } & \text { /kaya/ } & \text { 'rich' } & \text { /lamay/ } & \text { 'beckon' } \\ \text { /l/ } & \text { /lalu/ } & \text { 'pass' } & \text { /lihël/ } & \text { 'neck' } \\ & & & \text { /bumöl/ } & \text { 'doctor' } \\ \text { /r/ } & \text { /guru/ } & \text { 'teacher' 4 } & \text { /kaqgiter/ } & \text { 'so' } \\ & & & \text { /cermën/ } & \text { 'glass' }\end{array}$




\subsubsection{Vowel phonemes}

\subsubsection{Phonemic chart of the vowels}

There are eight vowel phonemes as shown in Table 2-3 below. These vowels tend to be short in closed or unaccented open syllables, with some of them having a different allophone in closed syllables.

Table 2-3. Urak Lawoi' vowel phonemes

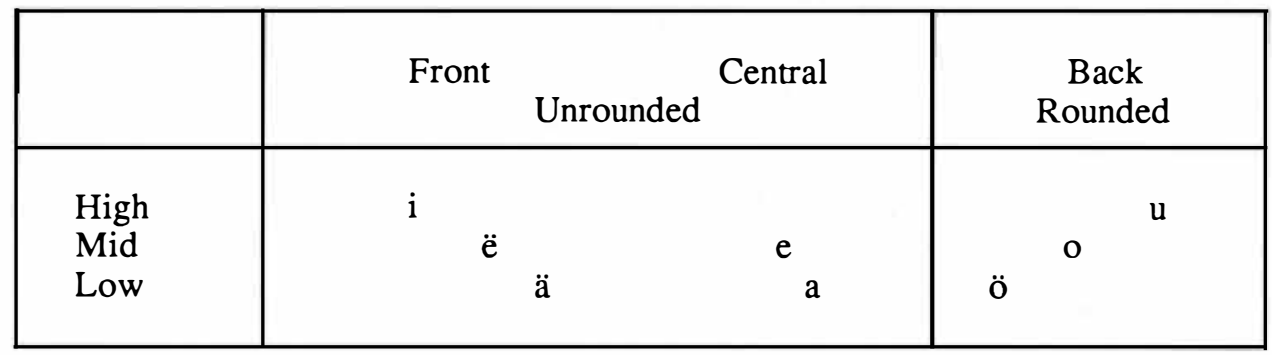

In the analysis given in my previous publication, I listed a high central vowel /i/ instead of the mid central /e/ shown here. It is possible that that vowel is the idiolect of some speakers, but I now consider that the mid central vowel is more correct for the POP dialect as a whole. This agrees with Amon's analysis of the AD dialect. Amon also includes dipthongs /ia/ and /ua/. These are discussed in Section 2.2.2.3.4. (Amon 1979:51).

\subsubsection{Frequency of occurrence of vowel phonemes}

This is set out in Table 2-4, showing the number of occurrences of each vowel in initial and final syllables, both for open and for closed syllables.

Table 2-4. Frequency of occurrence of vowel phonemes

\begin{tabular}{|c|rr|rr|r|}
\hline \multirow{2}{*}{ Syllables } & \multicolumn{2}{|c|}{ Initial } & \multicolumn{2}{|c|}{ Final } & Total \\
\hline Phoneme & Open & Closed & Open & Closed & \\
\hline $\mathrm{i}$ & 171 & 1 & 85 & 61 & 318 \\
$\ddot{\mathrm{e}}$ & - & 1 & 2 & 94 & 97 \\
$\ddot{\mathrm{a}}$ & 1 & - & 6 & 38 & 45 \\
$\mathrm{e}$ & 231 & 26 & - & 5 & 262 \\
$\mathrm{a}$ & 448 & 20 & 121 & 514 & 1103 \\
$\mathrm{u}$ & 248 & 1 & 59 & 39 & 347 \\
$\mathrm{o}$ & 2 & 3 & 1 & 199 & 205 \\
$\ddot{0}$ & 10 & 2 & 6 & 70 & 88 \\
\hline
\end{tabular}


There are three points of note:

The phoneme /e/ occurs in open syllables as the transition vowel [ə] in pre-syllables with a total of 231 occurrences. It also occurs in stressed closed syllables ending in /r/ with 26 occurrences in initial syllables and 5 in final syllables (see the comments on Table 2-8). In the Adang dialect, /er/ in final syllables occurs much more frequently than it does in POP and PYP dialects.

The mid and low vowels/ë ä o ö/occur infrequently except in closed final syllables.

In initial syllables there are more open syllables than there are closed syllables; the reverse applies in final syllables.

\subsubsection{Vocalic descriptions and contrasts and their interpretation}

\subsection{Front vowels:}

/i/ [i] a high close front unrounded vocoid, appearing in open syllables: /tali/ 'rope'

[1] a high open front unrounded vocoid, appearing in closed syllables: /baliq/ [balı] 'return'.

/ë/ [e] a mid close front unrounded vocoid, appearing in open and closed syllables: /ayë/ 'water'; /kulët/ 'skin'.

/ä/ [ع] a low close front unrounded vocoid, appearing in open and closed syllables: /cä/ 'grandfather'; /cicäq/'torn'.

Some typical contrasts between front vowels in similar or analogous environments in the POP dialectare:

\begin{tabular}{llllll}
\multicolumn{2}{l}{ High vowel: } & \multicolumn{2}{l}{ Mid vowel: } & \multicolumn{2}{l}{ Low vowel: } \\
/kepiq/ & 'squeeze' & /supëq/ & 'rice bag' & /sepäq/ & 'narrow' \\
/dikiq/ & 'little' & /sakëq/ & 'sick' & /sikäq/ & 'write' \\
/cebiq/ & 'stumble' & /sabëq/ & 'because' & /bäq/ & 'box' \\
/baliq/ & 'return' & /belëq/ & 'twist' & /peläq/ & 'strange' \\
/isi/ & 'contents' & /misël/ & 'even if & & \\
/pangin/ 'call' & /angën/ & 'wind' & & \\
& & /manëh/ & 'sweet' & /benäh/ & 'seed' \\
& & /bejëh/ & 'tin ore' & /bejäq/ & 'cold' \\
/tirih/ & 'leak' & /nilëh/ & 'trickle' & /siräh/ & 'betel nut'
\end{tabular}

2.2.2.3.2 Central vowels: /e/ [ə] is a mid open central unrounded vowel. It occurs as the brief transition vowel in pre-syllables: /tebak/ [təb $\Lambda \mathrm{k}]$ 'to chop down'; /tegah [təg $\Lambda \mathrm{h}$ ] 'to argue'. It also occurs before $/ \mathrm{r} /$ in stressed syllables and in some prefixes with the potential for stress (Section 2.2.1.3.12). Before $/ \mathrm{r} /$ it is phonetically a long mid close central unrounded vowel: /ler/

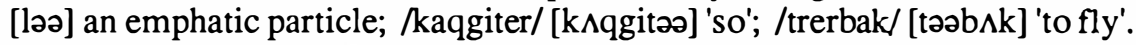

/a/ has two allophones: [ $\Lambda$ ] a mid open back-central unrounded vocoid appearing in closed syllables, and [a] a low open back-central vocoid appearing in open syllables; e.g. /rawak/ [raw $\Lambda k$ ] 'space', /raga/ [raga] 'basket'.

Contrasts between the mid and low central vowels in identical and similar environments are as follows: 
Mid vowel:

$\begin{array}{ll}\text { /gelak/ } & \text { 'bracelet' } \\ \text { /pedak/ } & \text { 'sword' } \\ \text { /kepan/ } & \text { 'clenched fist' } \\ \text { /semöc/ } & \text { 'ant' } \\ \text { /tepac/ } & \text { 'place' } \\ \text { /kelap/ } & \text { 'darkness' } \\ \text { /serma/ } & \text { 'cold' } \\ \text { /rerga/ } & \text { 'value, price' }\end{array}$

Low vowel:

/galak/ 'roller'

/padak/ 'field'

/kapan/ 'ship'

/samoc/ 'receive'

/dapac/ 'get'

/kalap/ 'pencil'

/sama/ 'the same'

/raga/ 'basket'

\subsection{Back vowels:}

/u/ [u] a high close back vocoid, slightly rounded: /pruc/ 'scatter'; /lalu/ 'pass'.

/o/ [u] a high open back vocoid, slightly rounded, appearing in closed syllables: /proc/ [pruiq] 'stomach'. 'lorry'.

[o] a mid close back vocoid, slightly rounded, appearing in open syllables: /nori/ [nori]

/ö/ [0] a low close back vocoid, slightly rounded: /budö/ 'stupid'; /röc/ 'reach'.

Contrasts between the various back vowels in identical and similar environments include the following:

High vowels:
/telul/ 'island name'
/lekuq/ 'bruised'
/celuq/ 'dip in'
/pethul/ 'spit'
/pemun/ 'gather'
/pruc/ 'scatter'

Mid vowels:
/telol/ 'egg'
/likoq/ 'cover up'
/seloq/ 'insert'
/gutol/ 'thunder'
/timon/ 'float'
/proc/ 'stomach'

Low vowels:

/pethöl/ 'front room'

/liköq/ 'swerve'

/jelöq/ 'pound'

/pethöl/ 'front room'

/timön/ 'cucumber'

/röc/ 'reach'

2.2.2.3.4 Diphthongs: Amon interprets the glided vowels [ia] and [ua] as single vowels $/ \mathrm{i}$ a/ and $/ \mathrm{u}$ a/ $(1979: 41,51,58,139)$. This conforms to the Thai patterm which has such complex vowels. As I hear these words in POP they have an inter-vocalic $/ y /$ or $/ w /$ with either similar stress on both the first and second segment or else they have a slightly heavier stress on the second syllable with the initial segment tending towards a pre-syllable. Therefore I have written such words as Ciya and Cuwa; e.g. /siyak/ 'light, daylight', /buwak/'to throw away'. Possibly, in this POP reflects the pronunciation of the older generation, who tend to pronounce intervocalic consonants that the younger generation ignore. This tendency occurs in Malay also, as in the word < perahu > 'boat', which is generally pronounced <prau >.

Abdullah $(1974: 9,18)$ lists the three diphthongs of Bahasa Malaysia as [aw], [ay] and [oy], spelled as $<\mathrm{au}\rangle,<\mathrm{ai}\rangle$ and $<\mathrm{oi}\rangle$ in that language. He lists $\langle\mathrm{ia}\rangle\langle\mathrm{iu}\rangle\langle\mathrm{ai}\rangle\langle\mathrm{au}\rangle\langle\mathrm{ui}\rangle$ and $<$ ua > as vowel sequences with each vowel syllabic, but sometimes separated by a semi-vowel. His three diphthongs are treated as VC combinations in UL: /aw/ /ay/ and /öy/: /pulaw/ 'island', /patay/ 'beach', /höy/ 'have not'. Of his six vowel sequences the two with an initial / $/ 2 /$ occur in UL with the semi-vowel /y/ inserted to make /iya/ and /iyu/: /semiya/ 'man', /hiyu/ 'shark'. The two with an initial /u/ have the semi-vowel /w/ inserted to make /uwi/ and /uwa/: /buwih/ 'pass by', 
/buwac/ 'do, make'. There is one anomalous word /deniya/ 'world' which phonetically follows the Thai pattern as [denia] but is written phonemically as /iya/.

The sequences starting with /a/ are not so simple. There are no clear instances of the /ai/ sequence. One possibility is the word /ayë/ 'water'. Malay used to write the cognate word as <ayer> but in modern Bahasa Malaysia it is written <air>, which appears to be one of Abdullah's vowel sequences. Another common Malay word with this sequence is <baik > 'good' which has the UL cognate /bajiq/, suggesting a connection with the Malay word <kebajikan> 'welfare, prosperity'. The sequence <au> is represented by the UL word /ba.u/ which phonetically has no medial consonant. Informants differ as to which consonant should be inserted but agree in rejecting /baqu/ which is the only way /ba.u/ can be represented in the Thai orthography.

Therefore UL is regarded as having no vowel diphthongs.

\subsection{Suprasegmental features}

These will be considered under the headings of Tone, Intonation, Stress, Vowel Length and Nasalisation.

\subsubsection{Tone}

UL is not tonal, and the only place where tone marking may be needed is in loan words from Thai. Thai speakers and UL speakers who have learnt to read in Thai schools tend to read UL words with an approximation to the tones which the Thai spelling would assign to a word of that pattern, but such tones are not evident in normal speech.

\subsubsection{Intonation}

Intonation is variable and may be attributed to speaker attitude. Intonation contours may terminate with a syntactic or emphatic particle, as discussed below, but this is a matter of user choice.

Amon describes two types of intonation contours: Falling Contour and Rising Contour (1979:12-17). She says that in the Falling Contour, the pitch of the last syllable falls to a lower level. This contour is used in ordinary statements and commands; e.g.:

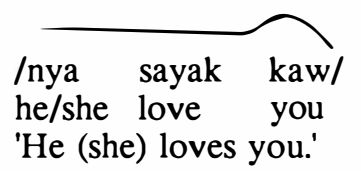

\footnotetext{
/bikas/

get up

'Get up!'
}

In the Rising Contour, the pitch of the last syllable rises to a higher level. Amon says, "This is used for questions, both polar questions and content questions, and also for certain intensifying statements and medial statements of narrative-type utterances" (1976:14-17). Examples she gives of such questions include the following: 
/P1kay/diha/
go to where

'Where will you go?' or 'Where are you going?'

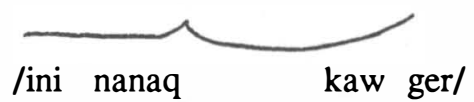

this child/children you qpt

'Is this your child (children)?'

The intensifying statements she describes end with a final intensifying particle such as /nö/, /ter/, and /ler/. I have no examples of this usage. What she refers to as "medial statements of narrative-type utterances" occur with a rising contour at the end of a sentence-medial phrase or clause, with a falling contour occurring at the end of the sentence. In the POP dialect such medial statements optionally occur with /ter/ at the end of the phrase or clause. This is of ten balanced with a sentence final emphatic particle/ler/; e.g.:

POP: /urak dëq sagol ter, nya turot cäw pi kaq Tokkha dah/ men in junk spt, they descend row go to Phuket ppt 'The men in the junk got into their boat and rowed to Phuket'

/banyaq tahot ter, kami phakhac besal dëq tupoq terbak ter ler/
many years spt, we (excl) together grow-up at village Terbak spt ept
'For many years we grew up together in the village of Terbak'
(spt = syntactic particle, ppt = past particle, and ept =emphatic particle)

One point not mentioned by Amon, but shown in her intonation contours, is that in the Falling Contour the pitch rises before it falls off sharply. In some cases it drops slightly before the rise. The point at which the rise takes place is usually on the last syllable, but it may move back to the penultimate syllable for reasons not yet analysed. Two contours not mentioned by Amon are the Staircase Contour and the Parenthetical Contour.

The Staircase Contour indicates strong emotion on the part of the speaker. It occurs more commnly with female speakers in a state of some agitation, and I have no instance of it in my text material. In this contour, each phrase is pitched at a successively higher pitch level, until the speaker breaks off at a relatively high level. I have seen this feature mentioned as occurring in Malay, but I have not been able to locate the source of reference.

The Parenthetical Contour occurs on a Parenthesis, a syntactic feature apparent at Sentence Level. This is a parenthetical statement occurring at the end of a sentence which either recapitulates the topic of the sentence, or else supplies supplementary information about some point arising out of the sentence. The sentence terminates with a normal falling contour, which is followed by a Parenthesis with a low, flat contour with a slight fall at the end.

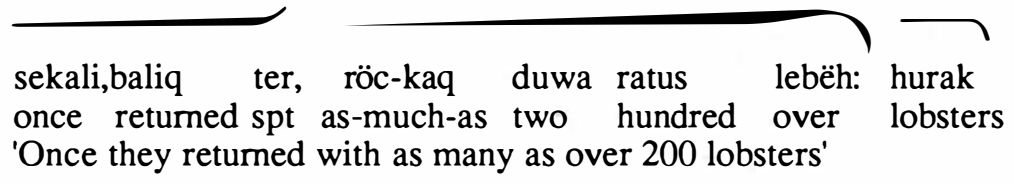


Here the Parenthesis recapitulates the subject of their catch, which had been omitted from the sentence because of the highlighting of the very large size of the catch on that occasion.

\begin{tabular}{|c|c|c|c|c|c|c|}
\hline $\begin{array}{l}\text { ikat dëq } \\
\text { fish at }\end{array}$ & $\begin{array}{l}\text { lawoc } \\
\text { sea }\end{array}$ & $\begin{array}{l}\text { ter, amët } \\
\text { spt, take }\end{array}$ & $\begin{array}{ll}\text { belëh } & \text { pi } \\
\text { get } & \text { go }\end{array}$ & $\begin{array}{l}\text { makat; } \\
\text { eat; }\end{array}$ & $\begin{array}{l}\text { sabëq } \\
\text { because }\end{array}$ & $\begin{array}{l}\text { kami } \\
\text { we }\end{array}$ \\
\hline $\begin{array}{ll}\text { naq } & \text { bri } \\
\text { will } & \text { give }\end{array}$ & $\begin{array}{l}\text { hidoq: } \\
\text { live: }\end{array}$ & $\begin{array}{l}\text { semuha } \\
\text { all }\end{array}$ & $\begin{array}{l}\text { hajaq } \\
\text { destit }\end{array}$ & & & \\
\hline
\end{tabular}

'The fish in the sea, we catch them and eat them, because we have to live, we who are so destitute.'

The sentence ends at the colon without saying who 'we', the subject of the sentence, refers to. In fact this is the first occurrence of a subject in this brief text. Then the missing Topic is stated in a parenthetical position, a very emotive term they use to describe their depressed way of life, which they regard as impossible to remedy. I hope later to comment on this in more detail in a paper on Discourse Level.

The intonation of Urak Lawoi' is a feature which merits further study. Similarly with the sister language, Malay, Payne describes intonation briefly in a pattem similar to UL, but says that "very little work has been done on Malay intonation" (Payne 1970:8-10, 92, 105).

\subsubsection{Stress}

In normal speech the main word stress falls on the penultimate syllable, as in Malay, with minor stress on the final syllable (Lewis 1947:18). When the penultimate syllable is a presyllable, this is unstressed, and the major stress falls on the last syllable.

Pre-syllables do not normally have any stress and the amount of transition (i.e. its vocalic clarity, length and prominence) is conditioned by the speed and rhythm of the phrase and ranges from zero to an unstressed [ə]. This is particularly evident in the five words starting with $/ \mathrm{h} /$ listed in Section 2.2.1.3.4 where the transition is of ten zero.

The rule that pre-syllables do not carry stress has three exceptions, the words /demiq/ 'small', /deniya/ 'world' and /semengac/ 'spirit'. As explained in Section 2.2.2.3.4 /deniya/ is phonetically a bi-syllabic word [də.nia] and has the word stress on the first syllable even although it is a presyllable. Similarly /demiq/ has the word stress on the first syllable, and /semengac/ has it on the penultimate syllable. The fact that the word stress here occurs on a pre-syllable may be due to these being words which originally had a vowel other than /e/ in the stressed syllable. So /deniya/ has the Malay cognate <dunia>, and /semengac/ has the cognate <semangat >. /demiq/ has no apparent Malay cognate but some POP speakers pronounce it [dumi?].

In tri-syllabic words there is a potential minor stress on the first syllable, when that syllable is the prefix /ber-/ /per-/ or /ter/. When these words occur in fast speech this first syllable is generally unstressed so that these prefixes occur with unstressed allomorphs [be- pe- te-], as described in Section 3.1.2.4. In phrase-final position they normally bear the minor stress. Marking major stress with " and minor stress with ' this contrast is seen as follows:

$$
\begin{aligned}
\text { /adapermelaw/ - } & \text { ["a.da pə.m."l } 1 \wedge w \text { "ba.ny } \Lambda \text { ] 'has many words' } \\
\text { - } & \text { ["a.da 'pəə.mə."l } 1 \Lambda w] \text { 'has a word' }
\end{aligned}
$$


In this example besides the variations in the first syllable of /permelaw/ it will be noted that the medial pre-syllable has zero transition in the first example and normal transition in the second example.

In compound and reduplicated words the stress occurs in the position where it would normally occur in each component of the compound or reduplication, but the last stress to occur is the major stress, and the previous stress or stresses are minor. In all cases the major stress occurs, but in rapid speech the minor stresses may lose their emphasis. Examples of stress patterns are as follows:

Word type:

$\begin{array}{lll}\text { Major + Minor } & \text { ["ma'ta] } & \text { 'eye' } \\ & \text { ["a'ri] } & \text { 'day' } \\ \begin{array}{l}\text { Pre-syllable + Major } \\ \text { Minor + Pre-syllable + Major }\end{array} & \text { ['pə"s } \Lambda \text { l] } & \text { 'large' } \\ \text { Compound } & \text { ["ma'ta"a'ri] } & \text { 'sun' } \\ & \text { ['si"pa'ku] } & \text { 'nail' } \\ \text { Reduplication } & \text { ['s } \Lambda \text { lbə"s } \Lambda \text { l] } & \text { 'important' } \\ & \text { ['ta"ma'ta] } & \text { 'policeman' }\end{array}$

Word stress is predictable and so does not need to be represented phonemically.

Clause stress falls on the last syllable of the last word in the clause.

\subsubsection{Vowel length}

Vowel length is not phonemic. Vowel length in unstressed syllables and pre-syllables tends to be shorter than that in stressed syllables. Vowels in closed syllables tend to be shorter than those in open syllables.

\subsubsection{Nasalisation}

There is sometimes slight nasalisation of vowels other than /e/ after a nasal consonant; e.g. /menangäh/ [məñang̃ ch] 'cry', /melengung/ [mələng̃ung] 'despondent'. In Thai, similar nasalisation occurs after nasal consonants and $/ \mathrm{h} /$, but it does not occur after $/ \mathrm{h} /$ in Urak Lawoi'; e.g. Thai <höy> 'shellfish' is nasalised, but the Urak Lawoi' /höy/ 'no, not, have not' is not nasalised.

When the penultimate syllable commences with a nasal consonant and the last syllable with a semi-vowel / w/ or / $/$ /, there is nasalisation of both syllables. The degree of nasalisation varies from one word to another and from one informant to another. With some informants it may cause the semi-vowel to change to a nasal at the same point of articulation. Some typical words are: 


\begin{tabular}{|c|c|c|}
\hline /nyawa/ & [nyããã] & 'body, self \\
\hline /penyawöq/ & [pənyã $\tilde{w} \tilde{\jmath} ?]$ & 'scoop net' \\
\hline /mawa/ & [mã w̃ã] & 'use a shaman's services' \\
\hline /nguwaq/ & [ngũ $\tilde{w} X^{?}$ ] & 'yawn' \\
\hline /mawös/ & [mã w̃õĩh mãmõĩh] & 'emerge from water' \\
\hline /bernyawa/ & [bə⿱nyã̃̃̃ã] & 'breathe' \\
\hline /kayoh/ & [kayoh] & 'paddle' (no nasalisation) \\
\hline /mengayoh/ & [məng̃ãỹoh məng̃anỹoh] & 'paddle' \\
\hline /kayën/ & [kayen] & 'f ishing line' (no nasalisation) \\
\hline /mengayën/ & [məng̃ãỹen məng̃anỹen] & 'fish with a line' \\
\hline
\end{tabular}

/mawa/ here contrasts with /maqwa/ 'gibbon' where the first syllable ends with a glottal and no nasalisation is evident.

There are two mono-syllabic words with strong nasalisation: /äh/ [ēh] 'have a bowel motion', /as/ [Xih] 'on the point of death'.

Nasalisation in UL is not phonemic and does not need to be represented.

\subsection{Function of the phoneme in the syllable}

This section will discuss the distribution of the phoneme as it functions in the syllables of mono-syllabic, bi-syllabic and tri-syllabic words. It will treat the final syllable first, as this is the major syllable and is obligatory in every word. It will then examine the initial syllable in bisyllabic words, and finally will consider tri-syllabic words.

\subsubsection{Final syllables}

The frequency of occurrence of initial consonants and vowels in final syllables is set out in Table 2-5.

Once again it will be noted how few occurrences of the aspirated voiceless stops there are. Another notable factor is the predominance of $/ \mathrm{a} /$ as the vowel in the final syllable. The vowel /e/ has only five occurrences in these 1300 POP words. If the same words in the AD dialect were analysed, it is estimated there would be 59 words with /er/ in the final syllable. 
Table 2-5. Frequency of occurrence of initial consonants and vowels in final syllables

\begin{tabular}{|c|c|c|c|c|c|c|c|c|c|}
\hline Initial consonant & $\mathrm{i}$ & $\ddot{\mathrm{e}}$ & $\ddot{a}$ & $\mathrm{e}$ & $\mathrm{a}$ & $\mathrm{u}$ & 0 & ö & Total \\
\hline$p$ & 11 & 8 & 5 & - & 55 & 8 & 18 & 4 & 109 \\
\hline $\mathrm{t}$ & 15 & 7 & 2 & 1 & 53 & 11 & 23 & 10 & 122 \\
\hline c & 6 & 1 & 4 & - & 22 & 1 & 5 & 2 & 41 \\
\hline $\mathrm{k}$ & 7 & 6 & 4 & - & 51 & 10 & 16 & 10 & 104 \\
\hline $\mathrm{q}$ & - & - & - & - & - & - & - & - & . \\
\hline zero & - & 2 & 2 & - & 6 & 3 & 2 & 1 & 16 \\
\hline $\mathrm{ph}$ & - & - & - & - & 1 & - & - & 1 & 2 \\
\hline th & - & - & - & - & 3 & 2 & 1 & 1 & 7 \\
\hline ch & 2 & - & - & - & 1 & 1 & - & - & 4 \\
\hline $\mathrm{kh}$ & - & - & - & - & 3 & 1 & 1 & 1 & 6 \\
\hline$b$ & 10 & 6 & 1 & 1 & 29 & 10 & 16 & 2 & 75 \\
\hline $\mathrm{d}$ & 8 & 5 & - & - & 31 & 6 & 13 & 3 & 66 \\
\hline $\mathrm{j}$ & 7 & 2 & 1 & - & 16 & 2 & 6 & - & 34 \\
\hline $\mathrm{g}$ & 8 & 1 & 1 & 1 & 20 & 5 & 3 & - & 39 \\
\hline $\mathrm{m}$ & 3 & 8 & 1 & - & 46 & 6 & 12 & 16 & 92 \\
\hline $\mathrm{n}$ & 10 & 8 & 2 & - & 45 & 2 & 8 & 5 & 80 \\
\hline ny & 4 & 1 & 4 & - & 16 & 2 & 6 & 1 & 34 \\
\hline ng & 5 & 4 & 3 & - & 33 & 2 & 7 & 4 & 58 \\
\hline $\mathrm{s}$ & 13 & 7 & 1 & 1 & 38 & 4 & 13 & 2 & 79 \\
\hline $\mathrm{h}$ & 1 & 5 & - & - & 16 & 7 & 6 & 2 & 37 \\
\hline 1 & 14 & 14 & 5 & 1 & 57 & 6 & 15 & 5 & 117 \\
\hline$r$ & 20 & 7 & 4 & - & 33 & 6 & 11 & 5 & 86 \\
\hline w & 2 & 1 & 2 & - & 36 & - & 9 & - & 50 \\
\hline$y$ & - & 3 & 2 & - & 24 & 3 & 9 & 1 & 42 \\
\hline Totals & 146 & 96 & 44 & 5 & 635 & 98 & 200 & 76 & 1300 \\
\hline
\end{tabular}



$2-6$.

The frequency of occurrence of vowels and final consonants in final syllables is set out in Table

Table 2-6. Frequency of occurrence of vowels and final consonants in final syllables

\begin{tabular}{|c|c|c|c|c|c|c|c|c|c|}
\hline Final consonant & $\mathrm{i}$ & $\ddot{\mathrm{e}}$ & $\ddot{a}$ & e & a & $\mathrm{u}$ & 0 & ö & Total \\
\hline $\mathrm{p}$ & 1 & 2 & - & - & 31 & - & 7 & - & 41 \\
\hline $\mathrm{t}$ & 1 & 13 & - & - & 41 & - & 16 & 2 & 73 \\
\hline c & - & - & - & - & 63 & 4 & 24 & 12 & 103 \\
\hline k & 22 & 2 & - & - & 88 & 2 & 31 & 10 & 155 \\
\hline $\mathrm{q}$ & 21 & 33 & 26 & - & 81 & 8 & 61 & 18 & 248 \\
\hline $\mathrm{m}$ & - & - & 1 & - & 7 & - & - & 2 & 10 \\
\hline $\mathrm{n}$ & 3 & 18 & - & - & 31 & 6 & 9 & 4 & 71 \\
\hline $\mathrm{ng}$ & 6 & 4 & 1 & - & 13 & 1 & - & 6 & 31 \\
\hline S & . & - & - & - & 32 & 13 & 1 & 4 & 50 \\
\hline $\mathrm{h}$ & 7 & 19 & 5 & - & 41 & 1 & 30 & 5 & 108 \\
\hline 1 & - & 3 & 1 & - & 34 & 2 & 20 & 4 & 64 \\
\hline$r$ & - & - & - & 5 & - & - & - & - & 5 \\
\hline w & - & - & 4 & - & 20 & - & - & - & 24 \\
\hline$y$ & - & - & - & - & 32 & 2 & - & 3 & 37 \\
\hline zero & 85 & 2 & 6 & - & 121 & 59 & 1 & 6 & 280 \\
\hline Totals & 146 & 96 & 44 & 5 & 635 & 98 & 200 & 76 & 1300 \\
\hline
\end{tabular}

Approximately $22 \%$ of the words end with an open syllable. $48 \%$ end with the stops /p t c k $\mathrm{q} /, 8.5 \%$ end with the nasals $/ \mathrm{m} \mathrm{n} \mathrm{ng} /, 12 \%$ with the fricatives $/ \mathrm{s} \mathrm{h} /$, and $9.5 \%$ with $/ \mathrm{r} \mathrm{w} \mathrm{y} /$.

In open syllables there are far more high vowels /i u/ than there are low vowels, /ë ä o ö/, but the contrary is true in closed syllables.

These final syllables are major syllables as defined in Section 2.1.1 in that they are obligatory and final in the word and have a greater variety of vowels. The fourth characteristic of a major syllable will be displayed in subsequent charts, which will show how the final syllable has a greater variety of final consonants than other types of syllables. 


\subsubsection{Initial syllables in bi-syllabic words}

Table 2-7 shows the frequency of occurrence of initial consonants and vowels in the initial syllables of bi-syllabic words. These include both pre-syllables and minor syllables.

Table 2-7. Frequency of occurrence of initial consonants and vowels in initial syllables of bi-syllabic words

\begin{tabular}{|c|c|c|c|c|c|c|c|c|c|}
\hline Initial consonant & $\mathrm{i}$ & $\ddot{\mathrm{e}}$ & $\ddot{a}$ & $\mathrm{e}$ & a & $\mathrm{u}$ & o & ö & Total \\
\hline$p$ & 15 & - & - & 26 & 38 & 13 & - & - & 92 \\
\hline $\mathrm{t}$ & 25 & - & - & 36 & 40 & 38 & 2 & 3 & 144 \\
\hline c & - & 1 & - & 12 & 16 & - & - & - & 29 \\
\hline $\mathrm{k}$ & 12 & - & - & 39 & 49 & 15 & 1 & - & 116 \\
\hline$q$ & - & - & - & - & - & - & - & - & - \\
\hline zero & 19 & - & - & - & 41 & 33 & - & - & 93 \\
\hline $\mathrm{ph}$ & - & - & - & 3 & 1 & 1 & - & - & 5 \\
\hline th & - & - & - & - & 2 & - & - & - & 2 \\
\hline ch & - & - & - & - & - & 2 & - & - & 2 \\
\hline kh & - & - & - & 1 & 1 & - & - & - & 2 \\
\hline$b$ & 16 & - & - & 32 & 50 & 40 & - & 3 & 141 \\
\hline d & 5 & - & - & 7 & 21 & 10 & - & - & 43 \\
\hline $\mathrm{j}$ & 1 & - & - & 7 & 24 & 5 & - & - & 37 \\
\hline $\mathrm{g}$ & 6 & - & - & 10 & 23 & 14 & - & - & 53 \\
\hline $\mathrm{m}$ & 12 & - & - & 9 & 31 & 11 & - & 2 & 65 \\
\hline $\mathrm{n}$ & 8 & - & - & - & 11 & 6 & 1 & - & 26 \\
\hline ny & 1 & - & - & 1 & 11 & - & - & - & 13 \\
\hline $\mathrm{ng}$ & - & - & - & 3 & 8 & 2 & - & - & 13 \\
\hline$s$ & 20 & - & 1 & 30 & 33 & 24 & - & 2 & 110 \\
\hline $\mathrm{h}$ & 2 & - & - & 4 & 12 & 6 & - & 1 & 25 \\
\hline 1 & 17 & - & - & 19 & 35 & 18 & - & - & 89 \\
\hline $\mathrm{r}$ & 11 & - & - & 18 & 19 & 10 & 1 & 1 & 60 \\
\hline $\mathrm{w}$ & - & - & - & - & 2 & - & - & - & 2 \\
\hline$y$ & 2 & - & - & - & - & 1 & - & - & 3 \\
\hline Totals & 172 & 1 & 1 & 257 & 468 & 249 & 5 & 12 & 1165 \\
\hline
\end{tabular}


Consonants /ph th ch $\mathrm{kh} \mathrm{w}$ y/ occur only rarely. Vowels /ë ä o ö/ seldom occur in minor syllables and never in pre-syllables. The vowel /e/ comprises $20 \%$ of the total, of which 229 occur in pre-syllables and 28 in minor syllables. Syllables with other vowels are minor syllables (Section 2.1.1).

As stated in Section 2.2.1.2, the only consonants occurring syllable-finally in initial syllables are / $\mathrm{p} \mathrm{k} \mathrm{q} \mathrm{m} \mathrm{n} \mathrm{ng} \mathrm{r/,} \mathrm{with} \mathrm{only} 54$ words in the data. An analysis of these words is shown in Table $2-8$.

Table 2-8. Frequency of occurrence of vowels and final consonants in initial syllables of bi-syllabic words

\begin{tabular}{|c|c|c|c|c|c|c|c|c|c|}
\hline $\begin{array}{l}\text { Final } \\
\text { Consonant }\end{array}$ & $\mathrm{i}$ & $\ddot{e}$ & $\ddot{a}$ & e & $\mathrm{a}$ & $\mathrm{u}$ & 0 & ö & Total \\
\hline $\mathrm{p}$ & 1 & - & - & - & - & - & - & - & 1 \\
\hline $\mathrm{k}$ & - & - & - & - & 2 & - & - & 2 & 4 \\
\hline$q$ & - & 1 & - & - & 13 & - & 1 & - & 15 \\
\hline $\mathrm{m}$ & - & - & - & - & 1 & 1 & - & - & 2 \\
\hline $\mathrm{n}$ & - & - & - & - & 1 & - & - & 2 & 3 \\
\hline ng & - & - & - & - & 3 & - & - & - & 3 \\
\hline I & - & - & - & 26 & - & - & - & - & 26 \\
\hline Totals & 1 & 1 & - & 26 & 20 & 1 & 1 & 4 & 54 \\
\hline
\end{tabular}

Comparing this table with Table 2-7 will show how the majority of these initial syllables are open syllables, with only $4.6 \%$ of them having a final consonant.

The 26 occurrences of /e/ with a final /r/ are the words with Cer in a minor syllable (Section 2.2.1.3.12).

A comparison of this Table with Table 2-6 serves to prove the point made in Section 2.1.1 that the major syllable has a greater variety of final consonants than other syllable types have.

\subsubsection{Tri-syllabic words}

125 tri-syllabic words have been analysed. Words which are obviously compounds, reduplications or onomatopeic words have been excluded, together with any place or personal names. Table 2-9 shows the frequency of occurrence of initial consonants and vowels in the first syllables of these words. 
Table 2-9. Frequency of occurrence of initial consonants and vowels in initial syllables of tri-syllabic words

\begin{tabular}{|c|rrrr|r|}
\hline $\begin{array}{c}\text { Initial } \\
\text { consonant }\end{array}$ & $\mathrm{i}$ & $\mathrm{e}$ & $\mathrm{a}$ & $\mathrm{u}$ & Total \\
\hline $\mathrm{p}$ & 1 & 13 & - & - & 14 \\
$\mathrm{t}$ & - & 11 & - & - & 11 \\
$\mathrm{c}$ & - & 1 & - & - & 1 \\
$\mathrm{k}$ & - & 17 & 3 & - & 20 \\
$\mathrm{ph}$ & - & - & 1 & - & 1 \\
$\mathrm{~b}$ & 1 & 25 & 1 & - & 27 \\
$\mathrm{~d}$ & - & 2 & - & 1 & 3 \\
$\mathrm{j}$ & - & 1 & 1 & - & 2 \\
$\mathrm{~g}$ & - & 1 & - & - & 1 \\
$\mathrm{~m}$ & - & 20 & - & - & 20 \\
$\mathrm{n}$ & - & 1 & - & - & 1 \\
$\mathrm{~s}$ & - & 21 & - & 1 & 1 \\
$\mathrm{~h}$ & - & - & 1 & - & 1 \\
\hline $\mathrm{l}$ & - & - & 1 & - & 125 \\
\hline Totals & 2 & 113 & 8 & 2 & 1 \\
\hline
\end{tabular}

This reveals that most of these initial syllables are pre-syllables with the vowel /e/, with the only other vowels being /i a u/, occurring in minor syllables. The fact that only a limited number of consonants appear is not significant as a larger sampling would no doubt fill the gaps.

The words can be further divided into those which include prefixes and those which do not. 69 words do not include prefixes, with the following combinations of syllables:

\begin{tabular}{cl} 
Minor + major + minor & \multicolumn{1}{c}{12 words, e.g.: } \\
/biyasa/ & 'accustomed to' \\
/piqisaq/ & 'leaf rolled for a cigarette' \\
/phahadak/ & 'a spirit festival' \\
/kaqhami/ & 'how?' \\
/duhulu/ & 'before' \\
/suwara/ & 'voice'
\end{tabular}




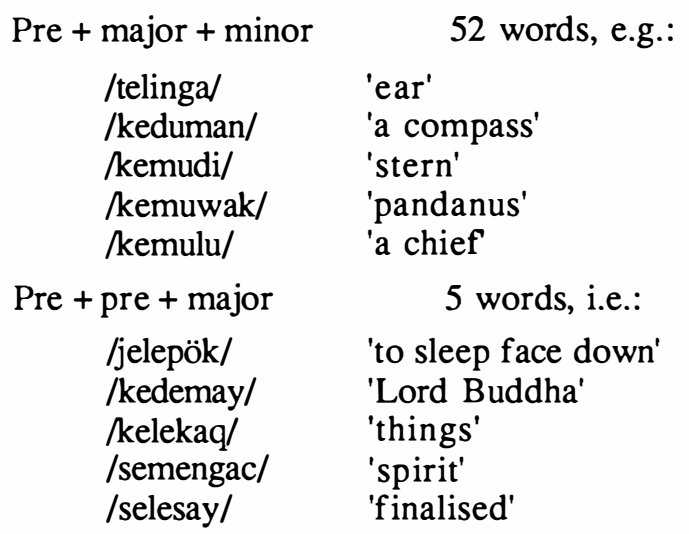

56 of the tri-syllabic words include a prefix /meN-/, /ber-/, /per-/, /ter-/, /peN-/, /se-/, or /keN-/. In some cases it is difficult to decide which is a prefix and which is not. The analysis of the words with prefixes is discussed in Section 3.1.2. Most of these prefixes are pre-syllables, but /ber-/, /per-/ and /ter-/ have allomorphs as set out in that section, with the allomorphs [ber-], [per-] and [ter-] being minor syllables with a secondary stress, and the allomorphs [be-], [pe-] and [te-] being unstressed pre-syllables.

In these 125 tri-syllabic words, only three have an initial syllable ending with a consonant. These words with their Malay cognates are:

$\begin{array}{lll}\text { UL: } & \text { Malay cognate: } & \\ \text { /kaqhami/ } & \text { bagaimana } & \text { 'how?' } \\ \text { kaqgini/ } & \text { bagini } & \text { 'in this way, so' } \\ \text { /kaqgiter/ } & \text { bagitu } & \text { 'in that way, thus' }\end{array}$

It appears that these three words were originally compound words. Winstedt's Malay Dictionary suggests that $<$ bagini $>=<$ bagai ini $>$, and $<$ bagitu $>=<$ bagai itu $>(1972: 26)$. It is possible that the Malay < bagai > 'sort, kind' is the source of the first syllable of these three words, with the UL words using the second syllable of $<$ bagai $>$, while the Malay < bagini $>$ and $<$ bagitu $>$ use the first syllable, and $<$ bagaimana $>$ retains the whole word.

\subsection{Variations found in Adang and Phuket Young People's dialects}

\subsubsection{Consonant clusters}

On the basis of the UL syllable patterns, Amon interprets [pl tl cl kl kw bl gl sl sr ml mr] as consonant clusters (Amon 1979:40-41; 1983:11-12). Typical words as listed by her are given below with the English gloss for each word, and with the relevant Malay cognate, where it is known.

$\begin{array}{lll}\text { Adang: } & \text { Malay: } & \text { English } \\ \text { plita } & \text { pelita } & \text { 'lamp' } \\ \text { tlinga } & \text { telinga } & \text { 'ear' } \\ \text { claka } & \text { celaka } & \text { 'curse' } \\ \text { klinöng } & & \text { 'shade, screen' } \\ \text { klamë } & \text { kelapa } & \text { 'coconut' } \\ \text { krebaw } & \text { kerbau } & \text { 'buffalo' }\end{array}$




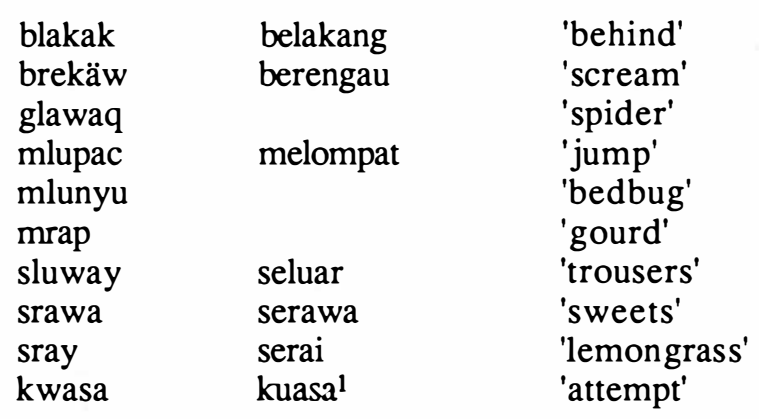

${ }^{1}$ In Malay, [berengau] means 'a musical instrument (no longer extant)', and [kuasa] means 'power'.

The words which Amon lists with a consonant cluster of which the second member is $/ 1$, are words into which POP speakers frequently insert the transition /e/; e.g. /pelita/ 'lamp', /telinga/ 'ear', et cetera. Some POP and PYP speakers omit the /e/; some PYP speakers may also omit the $\Lambda /$ in certain words of this class; e.g. /telaga/ 'a well' becomes [taga], and /seluwal/ 'trousers' becomes [suway].

The words [brekäw] and [krebaw] in the AD dialect are words with the vocoid cluster [ə2] as described in Section 2.2.1.3.12. In POP they are written phonemically as /brerkäw/ and /krerbaw/.

The Adang words [sray] and [mrap] are pronounced in POP with the transitional /e/ and are written phonemically as/seray/ and /merap/.

The AD word [kwasa] is regarded as a tri-syllabic word in POP, and is written/kuwasa/.

Amon also interprets the voiceless aspirated stops [ph th $\mathrm{ch} \mathrm{kh}$ ] as being phonemically consonant clusters. As discussed in Section 2.2.1.3.2, I have interpreted them as being phonemic consonants /ph th $\mathrm{ch} \mathrm{kh} /$.

Amon lists four words with the clusters [hl hn hny], but considers that there were insufficient examples of each to establish them as members of the inventory of phonemes (Amon 1979:41-42). As set out in Section 2.2.1.3.4, I have interpreted these as words where an initial pre-syllable /he-/ has light to zero transition.

\subsubsection{Lateral [1]}

In the POP dialect there are words ending with $/ /$ (Section 2.2.1.3.10). In the PYP dialect the $\mathrm{N} / \mathrm{is}$ omitted after front vowels and becomes [y] after central and back vowels. In the AD dialect, [1] is omitted after front vowels as in PYP. Where it follows a central or back vowel in POP, the POP CVl is replaced by Cer in AD. In these words /er/ carries the same stress as any other syllable in this position:

\begin{tabular}{|c|c|c|c|c|c|}
\hline $\begin{array}{ll}\text { POP: } & {[\text { lihel] }} \\
& {[\text { bas } 1 \text { l] }} \\
& {[\text { jahuḷ] }} \\
& \text { [tuhol]] } \\
& \text { [bumol] }\end{array}$ & PYP: & $\begin{array}{l}\text { [lihe] } \\
\text { [bas^y] } \\
\text { [jahuy] } \\
\text { [tuhoy] } \\
\text { [bumoy] }\end{array}$ & $\mathrm{AD}:$ & $\begin{array}{l}{[\text { lihe] }} \\
\text { [bəsəə] } \\
\text { [jahəə] } \\
\text { [tuhəə] } \\
\text { [buməə] }\end{array}$ & $\begin{array}{l}\text { 'neck' } \\
\text { 'large' } \\
\text { 'flare up' } \\
\text { 'dried' } \\
\text { 'doctor' }\end{array}$ \\
\hline
\end{tabular}




\subsubsection{Semivowel [r]}

In the AD dialect [r] occurs syllable-initially and in consonant clusters the same as in the POP dialect. Because AD uses Cer where POP uses CVI as described in the previous paragraph, $\mathrm{AD}$ has many more words with Cer in the major syllable than the five words in POP. Amon writes them phonemically as /e/.

In PYP dialect, the pre-syllable Ce occurs where POP has the minor syllable Cer. Of the five POP words with Cer in major syllables, PYP has one ending with Cä, and four ending with Cer:

\begin{tabular}{|c|c|c|c|c|}
\hline POP: & $\begin{array}{l}\text { /srerpaq/ } \\
\text { /kaqgiter/ } \\
\text { /ter/ } \\
\text { /ler/ } \\
\text { /ger/ } \\
\text { /namber/ }\end{array}$ & PYP: & $\begin{array}{l}{[\mathrm{s} \partial \mathrm{p} \wedge \mathrm{q}]} \\
{[\mathrm{k} \wedge \mathrm{qgit}]} \\
{[\mathrm{t} \partial \sim \mathrm{t} \varepsilon]} \\
{[\mathrm{l} \partial]} \\
{[\mathrm{g} \partial \partial]} \\
{[\text { nambəə]}}\end{array}$ & $\begin{array}{l}\text { 'almost' } \\
\text { 'so' } \\
\text { syntactic particle } \\
\text { emphatic particle } \\
\text { interrogative partic } \\
\text { 'number' (ELW) }\end{array}$ \\
\hline
\end{tabular}

\subsubsection{Vowel phonemes}

Amon's description of the front vowels in the AD dialect is similar to that given in Section 2.2.2.3 for POP vowels, but in some AD words the vowels differ from the equivalent POP words; e.g. POP /bukëq/ 'hill' becomes <bukiq > in AD, and POP /urä/ 'to pour out' becomes $\mathrm{AD}<$ ure > (Amon 1979:52). These are typical of words that differ from village to village, and from one speaker to another.

For central vowels in AD, Amon describes the allophones of /e/ as a lower mid open central unrounded vowel occurring in pre-syllables, and a mid close back central unrounded vowel occurring in open major syllables (Amon 1979:53). She does not mention /e/ as occurring in minor syllables, as described in Section 2.2.1.3.12 above.

The phonetic details of the AD back vowels are similar to those of the POP dialect, but Amon's analysis of them into phonemes differs from my analysis of POP. She groups [u] and $[u]$ as the two allophones of $/ \mathrm{u} /$, with $[\mathrm{u}]$ in open syllables, and $[\mathrm{u}]$ in closed syllables; then she describes [o] as the only member of the /o/ phoneme, occurring only in closed syllables (Amon 1979:53-54). In contrast with this, I analyse [u] as the sole member of the / $\mathrm{u} /$ phoneme occurring in both open and closed syllables, while [u] and [o] are the allophones of /o/ occurring in closed and open syllables respectively. Some of the contrasts on which this analysis was based are listed in Section 2.2.2.3.3. These contrasting analyses could reflect differences between the two dialects, or could be a matter of difference of interpretation. Literature published by me using a Thai orthography based on my interpretation has been read by speakers of POP and PYP without any difficulty or comment. It has not been possible to check this spelling with speakers of the AD dialect. 


\section{CHAPTER 3 \\ WORD LEVEL}

Word level is the level below Phrase Level and is made up of words which function to fill structural slots at Phrase Level. The phonological structure of the word is made up of syllables as described at Phoneme Level.

Normally words are described as composed of morphemes, with the morpheme being the smallest unit of lexical meaning in the language, which is described in the Morpheme Level of the syntactic description. In UL the vast majority of words are composed of one morpheme with a minimum of affixation, contrasting with Bahasa Malaysia which has many freely-used affix morphemes. Therefore the morpheme level of UL has not been described separately, but is included in this chapter with the morphemes classed as stems and affixes.

The word is defined as "a minimal free form" in the UL language; that is, it is the smallest unit of the language which is free to stand by itself in an utterance. In this the word contrasts with the particle, which phonologically is made up of syllables as is the word, but which is not free to stand by itself in an utterance. So from the viewpoint of the phonological structure a "word" includes both words and particles, but when their respective functions are in view, a "word" contrasts with a "particle".

This chapter will first describe the structure of the word, and then the various classes of words and particles which function at higher levels.

\subsection{Structure of the word}

The four types of words to be described are (1) words having a stem only, without affixation, (2) words with affixation, (3) reduplicated words, and (4) compound words.

\subsubsection{Words without affixation}

In the UL texts which provide the data for this thesis, the vast majority of words do not have any affix. There are only 441 occurrences of words with obvious prefixes. This does not include words where the prefix /meN-/ has been abbreviated by the omission of the $\langle\mathrm{me}-\rangle$, as described in Section 3.1.2.4.1. 
Words consisting of a stem only may have one, two or three syllables. A sample of 1425 words analysed showed that the majority were bi-syllabic, being $81.7 \%$ of the total, while only 9.5\% were mono-syllabic, and $8.8 \%$ were tri-syllabic.

$\begin{array}{lll}\text { Mono-syllabic word: } & \text { paq } & \text { 'father' } \\ \text { Bi-syllabic word } & \text { raga } & \text { 'basket' } \\ \text { Tri-syllabic word } & \text { belumok } & \text { 'funnel, exhaust' }\end{array}$

The types of syllables which can function in the stem are described in the previous chapter.

\subsubsection{Words with affixation}

UL has three verbal prefixes, two nominal prefixes, and three miscellaneous prefixes. There are no infixes and only one instance of a suffix. The verb/berhagiq/'to divide, share' is cognate to the Malay word <bahagi $>$, which adds a suffix to form <bahagian $>$ 'a division, share'. The POP word /berhagët/ 'a division, share' seems to be derived from this Malay word, but there is no other UL word with such a suffix. Therefore this word is regarded as an isolated case, which does not establish a pattern.

There are not sufficient occurrences of prefixed words in the corpus to identify all the meanings they carry, but reference to Abdullah's work on the morphology of Malay permits the following identifications to be made (Abdullah 1974).

\subsubsection{Verbal prefixes}

The three verbal prefixes are /meN-/, /ber-/, /ter-/, with morphophonemic variations as set out in sub-section 3.1.2.4. These prefixes normally occur with verbs, operating as an inflection. They sometimes occur with a noun or other part of speech to give a derived verbal meaning.

\subsection{Prefix /meN-/}

/meN-/ is a prefix with morphophonemic variation as described in Sub-section 3.1.2.4.1. It is prefixed to transitive and intransitive action verbs with no evident change in their meaning:

$\begin{array}{llll}\text { lihac } & \text { 'to see' } & \text { melihac } & \text { 'sees' } \\ \text { rigaq } & \text { 'to catch' } & \text { merigaq } & \text { 'catches' } \\ \text { lupac } & \text { 'to leap' } & \text { melupac } & \text { 'leaps' }\end{array}$

$/ \mathrm{meN}-/$ is also prefixed to adjectival verbs, altering their meaning from the description of a state to that of an action:

$\begin{array}{llll}\text { segat } & \text { 'to be lazy' } & \text { menyegat } & \text { 'is lazy' } \\ \text { sesan } & \text { 'to be sorry' } & \text { menyesan } & \text { 'is mourning' }\end{array}$

This prefix is also af fixed to some nouns, changing them into action verbs:

$\begin{array}{llll}\begin{array}{l}\text { kayën } \\ \text { kilas }\end{array} & \text { 'fishing line' } & \begin{array}{l}\text { mengayën } \\ \text { mengilas }\end{array} & \begin{array}{l}\text { 'to fish with a line' } \\ \text { 'to haul in with a windlass' }\end{array}\end{array}$




\subsection{Prefix /ber-/}

The prefix /ber-/ adapts an action verb to describe a state or a practice, or else gives the verb a reflexive, possessive, reciprocal, repetitive or productive meaning. This parallels the Malay usage described by Abdullah (1974:109-111). It can also give a verb a causative meaning. When prefixed to a noun or other part of speech, it gives it the force of a verb with these meanings.

Stative (describing a state or practice):

$\begin{array}{llll}\text { krerja }(\mathrm{vac}) & \text { 'to work' } & \text { berkrerja } & \text { 'to be working' } \\ \text { prak }(\mathrm{nn}) & \text { 'war' } & \text { berprak } & \text { 'to be fighting' } \\ \text { siyak }(\mathrm{nn}) & \text { 'daylight' } & \text { bersiyak } & \text { 'to do something through the night' } \\ \text { ados }(\mathrm{exc}) & \text { 'cry of pain' } & \text { berados } & \text { 'to be crying in pain' }\end{array}$

Reflexive (actions performed on the doers of the action):
akëq (vac) 'to lift'
berakëq
'to move one's residence'

Possessive (state of possessing, using or wearing the objects denoted by the noun):

$\begin{array}{llll}\text { bini }(\mathrm{nn}) & \text { 'wife' } & \text { berbini } & \text { 'to be married' } \\ \text { kudën }(\mathrm{nn}) & \text { 'scabies' } & \text { berkudën } & \text { 'to have scabies' }\end{array}$

Reciprocal (reciprocal action):

tumoh (vac) 'to box' bertumoh 'to be boxing together'

Repetitive (repetitive action):

ramay (vaj) 'fun, crowded' beramay 'to be having fun together' gelaq (vac) 'to laugh' bergelaq 'to be laughing'

Productive (indicating production of the object named by the noun):
anaq (nn) 'child'
ubac $(\mathrm{nn}) \quad$ 'medicine'
beranaq 'to give birth to'
berubac 'to treat by witchcraft'

Causative (causing the action to occur):

$\begin{array}{llll}\text { pi (vac) } & \text { 'to go' } & \text { berpi } & \text { 'to cause to go' } \\ \text { makat (vac) } & \text { 'to feed' } & \text { bermakat } & \text { 'to give food to' } \\ \text { timon (vac) } & \text { 'to float' } & \text { bertimon } & \text { 'to refloat (a sunken vessel)' }\end{array}$

\subsection{Prefix /ter-/}

The prefix /ter-/ gives a verb an unintentional, accidental or a completive meaning. It may be used with other parts of speech to change them to a verb with this meaning.

$\begin{array}{llll}\text { letak (vac) } & \text { 'to lie down' } & \text { terletak } & \text { 'lying sprawled out' } \\ \text { ketap (vac) } & \text { 'to reap' } & \text { terketap } & \text { 'reaped' } \\ \text { hutak (nn) } & \text { 'a debt' } & \text { terhutak } & \text { 'to be in debt' }\end{array}$




\subsubsection{Nominal prefixes}

The nominal prefixes are /peN-/ and /per-/ with morphophonemic variation as set out in Subsection 3.1.2.4. These are derivational prefixes which form a noun from a verb stem.

(1) When the affix /peN-/ is prefixed to an action verb, the result is a noun meaning the person or object by which the action of the verb is carried out:

$\begin{array}{llll}\text { churi } & \text { 'to steal' } & \text { penyuri } & \text { 'a thief } \\ \text { samon } & \text { 'to rob' } & \text { penyamon } & \text { 'a robber' } \\ \text { suroh } & \text { 'to send on a task' } & \text { penyuroh } & \text { 'a messenger' }\end{array}$

When /peN-/ is prefixed to an adjectival verb, it signifies the state which is the result of that verb:

$\begin{array}{llll}\text { sakëq } & \text { 'to be sick' } & \text { penyakëq } & \text { 'illness' } \\ \text { takoc } & \text { 'to be afraid' } & \text { penakoc } & \text { 'fearful' }\end{array}$

(2) When the rare affix /per-/ is prefixed to a verb, it results in a noun giving the result of the action of that verb:

$\begin{array}{llll}\text { melaw } & \text { 'to speak' } & \text { permelaw } & \text { 'a word' } \\ \text { buwac } & \text { 'to do' } & \text { perbuwac } & \text { 'action' }\end{array}$

\subsubsection{Miscellaneous prefixes}

3.1.2.3.1 There is a prefix $<k e->$ in Malay which turns a cardinal number into an ordinal number. In UL this prefix only occurs with /duwa/ 'two', resulting in the verbal adjective /keduwa/ 'to be second'. For other numerals, the same sense is obtained by using a relative clause; e.g. /nu sa/ 'the first'.

3.1.2.3.2 Three UL words have been listed with the prefix /ker-/, with insufficient data to assign a meaning to the prefix. Abdullah says that in Malay the prefix $<k e->$ which occurs with numerals, also occurs with certain verbs to "indicate state or action of a verb, with a certain amount of intensification" (Abdullah 1974:90). This seems appropriate for these three UL words, until further material permits a more precise description to be formulated:

\begin{tabular}{|c|c|c|}
\hline berlol & 'to starve' & $\begin{array}{l}\text { siyaq kerberlol mati } \\
\text { 'ready to starve to death' }\end{array}$ \\
\hline betol & 'to tease' & $\begin{array}{l}\text { nya usiq kerbetol } \\
\text { 'he plays teasingly' }\end{array}$ \\
\hline belakak & 'behind' & $\begin{array}{l}\text { \#nya ingac naq buwac kerbelakak kaq Yesu. } \\
\text { he thinks to do behind-back to Jesus } \\
\text { 'He intends to betray Jesus' (Mark 14:10) }\end{array}$ \\
\hline
\end{tabular}


3.1.2.3.3 There is a prefix /se-/ which basically means 'one', being an allomorph of /sa/ 'one'. It occurs prefixed to many words with this numerical meaning, but it also acts as a prefix to a noun with the meaning 'the whole of'. So /mata/ means 'eye', but /se-mata/ means 'with the whole eye', i.e. 'wholeheartedly', which functions as an adverb.

Functioning numerically:

$$
\text { ikol se-ikol 'one tail' }
$$

Functioning as an adverb:

$\begin{array}{llll}\text { kawat } & \text { 'a group' } & \text { se-kawat } & \text { 'altogether' } \\ \text { mata } & \text { 'an eye' } & \text { se-mata } & \text { 'wholeheartedly' }\end{array}$

\subsubsection{Morphophonemic variations}

Morphophonemic variation occurs with the prefixes $/ \mathrm{meN}-/$ and $/ \mathrm{peN}-/$, and in another pattem with /ber-/, /ter-/, and /per-/. There is no variation with the prefixes /ke-/ and /se-/.

3.1.2.4.1 In the prefixes $/ \mathrm{meN}-/$ and $/ \mathrm{peN}-/, \mathbf{N}$ stands for a nasal consonant. Where these prefixes are attached to a stem which has a stop or the fricative /s/ as the initial consonant, that consonant changes to a nasal consonant at the same point of articulation. When the stem commences with any other consonant or with a vowel, the prefix nasal $/ \mathrm{N}-/$ is omitted. The changes involved are set out in Table 3-1. It will be noted that in this morphophonemic change, the initial glottal does not function as a stop. This agrees with the decision at Phoneme Level to regard it as non-phonemic word-initially (Section 2.2.1.3.6).

Table 3-1. Morphophonemic changes with the prefixes /meN-/ and /peN-/

\begin{tabular}{|c|c|c|c|c|c|}
\hline $\begin{array}{l}\text { Stem } \\
\text { initial C }\end{array}$ & $\begin{array}{l}\text { Becomes } \\
\text { Nasal C }\end{array}$ & Verb and gloss & $\begin{array}{c}\text { With /meN-/ } \\
\text { prefix }\end{array}$ & $\begin{array}{c}\text { With /peN-/ } \\
\text { prefix }\end{array}$ & Gloss \\
\hline $\begin{array}{l}\mathrm{p}, \mathrm{b} \\
\mathrm{t}, \mathrm{d} \\
\mathrm{c}, \mathrm{j}, \mathrm{s} \\
\mathrm{k}, \mathrm{g}\end{array}$ & $\begin{array}{l}\mathrm{m} \\
\mathrm{n}\end{array}$ & $\begin{array}{l}\text { bawa 'to carry' } \\
\text { suroh 'send' } \\
\text { takoc 'to fear' } \\
\text { didëh 'to boil' } \\
\text { curi 'to steal' } \\
\text { jelöq 'to pound' } \\
\text { segat 'be lazy' } \\
\text { kilas 'windlass' } \\
\text { gatöq 'to hit' }\end{array}$ & $\begin{array}{l}\text { memawa } \\
\text { menakoc } \\
\text { menidëh } \\
\text { menyegat } \\
\text { mengilas } \\
\text { mengatöq }\end{array}$ & $\begin{array}{l}\text { penyuroh } \\
\text { penakoc } \\
\text { penyuri } \\
\text { penyelöq }\end{array}$ & $\begin{array}{l}\text { 'to summon' } \\
\text { 'messenger' } \\
\text { 'is afraid' } \\
\text { 'f earful' } \\
\text { 'boil' } \\
\text { 'a thief' } \\
\text { 'a mortar' } \\
\text { 'is lazy' } \\
\text { 'haul in' } \\
\text { 'hits' }\end{array}$ \\
\hline
\end{tabular}


Some exceptions to this pattern have been noted: /jadi/ 'to become' becomes /mejadi/ instead of */menyadi/; /jaga/ 'to guard' becomes /mejaga/ instead of */menyaga/; /belëh/ 'to get' becomes /mebelëh/ instead of */memelëh/; /gatöq/ 'to hit' becomes /penyatöq/ 'a hammer'. Possibly this indicates that the present $\mathrm{UL} / \mathrm{meN}-/$ and /peN-/ prefixes incorporate what were originally two different prefixes with different morphophonemic patterns.

Although these prefixes resemble the Malay prefixes $<\mathrm{meN}->$ and $<\mathrm{peN}->$, yet the pattern of change is not the same as that in Bahasa Malaysia as described by Abdullah (1974:49-52).

Some phonological variations occur in the pronunciation of these prefixes. Words with the /meN-/ prefix are optionally abbreviated by the omission of the <me->; e.g. /mawa/ instead of /memawa/, /nakoc/ instead of /menakoc/, et cetera. This is a matter of the speaker's preference, and seems capable of application to most words with this prefix.

3.1.2.4.2 Words with the /ber-/, /per-/ and /ter-/ prefixes have free fluctuation between allomorphs [Cer- $\sim \mathrm{Ce}$-], with the Cer- allomorph bearing an optional secondary stress. In this it contrasts with the Cer- syllables described in Section 2.2.1.3.12, where Cer- is the penultimate syllable of the stem and takes primary stress. Words with these prefixes with /ha-/ as the first syllable of the stem have free fluctuation between Ce- and /pha-/; e.g. /behagiq/ 'to share' becomes /phahagiq/; /pehadak/ 'protecting' becomes/phahadak/.

In three words which commence with $/ /$, the prefix /ber-/ becomes $/ \mathrm{p}-/$ :

$\begin{array}{llll}\text { lihac } & \text { 'to see' } & \text { plihac } & \text { 'to be revealed' } \\ \text { lepas } & \text { 'to be free' } & \text { plepas } & \text { 'to free' } \\ \text { lekac } & \text { 'to kindle' } & \text { plekac } & \text { 'to be kindled' }\end{array}$

The /ber-/ prefix may be abbreviated by omitting the /e/ or the /er/; e.g. /beringac/ 'to think' may be pronounced /bringac/. Before stems beginning with /r/ the Ce-allomorph occurs; i.e. /rasa/'to feel' becomes /berasa/not/berrasa/.

\subsubsection{Reduplicated words}

There are three types of reduplication: full reduplication, partial reduplication, and rhyming reduplication.

\subsubsection{Full reduplication}

In full reduplication the whole word is repeated. Usually the base word is an adjectival verb, which when reduplicated acts as an adverb:

$\begin{array}{llll}\text { dikiq } & \text { 'a little' } & \text { dikiq-dikiq } & \text { 'a little' } \\ \text { bidik } & \text { 'besides' } & \text { bidik-bidik } & \text { 'nearby' } \\ \text { lama } & \text { 'long (of time)' } & \text { lama-lama } & \text { 'for a long time' }\end{array}$

What appears to be full reduplication of action verbs occurs in the Head Verb slot of the verb phrase and is interpreted as a head verb repeated for emphasis: 
(nya) melupac melupac ler

she leaps leaps ept

'She was leaping and leaping'

(ulal) lihac pangöq pangöq lihac kaq nibini

snake looks rising rising looks at woman

'The snake was rising up looking at the woman'

There are some cases of full reduplication of a noun with a verbal prefix /ber-/ prefixed to the reduplication to make a verbal adjective:

$\begin{array}{llll}\text { guru } & \text { 'a teacher' } & \text { berguru-guru } & \text { 'to be highly taught' } \\ \text { kudën } & \text { 'scabies' } & \text { berkudën-kudën } & \text { 'to be covered with scabies' }\end{array}$

There is one case of an active verb being fully reduplicated but with /ber-/ prefixed to the second stem in the reduplication. This is used of a shaman carrying out his incantations and seems to imply a whole group of repeated actions:

buwac 'to do' buwac-berbuwac 'to be performing'

There are isolated cases of the reduplication of a noun to make an indefinite plural, as is done in Malay, and the reduplication of an indefinite pronoun for intensification:

$\begin{array}{llll}\text { kawat } & \text { 'a friend' } & \text { kawat-kawat } & \text { 'f riends' } \\ \text { nama } & \text { 'anything' } & \text { nama-nama } & \text { 'anything at all' }\end{array}$

\subsubsection{Partial reduplication}

Partial reduplication usually takes the form of the final syllable of the stem word followed by the repetition of the stem. In most cases this converts a noun into a noun of related meaning:

$\begin{array}{llll}\text { bini } & \text { 'wife' } & \text { nibini } & \text { 'woman' } \\ \text { laki } & \text { 'husband' } & \text { kilaki } & \text { 'man' } \\ \text { pisak } & \text { 'banana' } & \text { sak-pisak } & \text { 'rubbing strake (on a boat)' } \\ \text { mata } & \text { 'eye' } & \text { ta-mata } & \text { 'policeman' }\end{array}$

When this form of reduplication occurs with a verb, the resultant word is an adverb:

$\begin{array}{llll}\text { unol } & \text { 'to retreat' } & \text { nol-unol } & \text { 'retreating' } \\ \text { belëh } & \text { 'can, be able' } & \text { lëh-belëh } & \text { 'as much as possible' } \\ \text { kaqhami } & \text { 'how' } & \text { hami-kaqhami } & \text { 'however it may be' }\end{array}$

The noun /duwëq/ 'money' is partially reduplicated with a /ber-/ prefix inserted before the second part of the reduplication: /wëq-berduwëq/. This seems to mean a variety of financial transactions. 


\subsubsection{Rhyming reduplication}

There are some cases of rhyming reduplication where no regular pattern is evident:

\begin{tabular}{|c|c|c|c|}
\hline \multicolumn{4}{|r|}{ 'scattered everywhere' } \\
\hline brani & 'brave' & beni-brani & 'to be bold' \\
\hline giräq & ?? & gäq-giräq & 'a bicycle' \\
\hline
\end{tabular}

The verb /lihac/ 'to look' is reduplicated in two different ways, giving an intensification of its meaning:
(kunya) masoq pi berlihac-lac
they enter go looking-looking
'They went in and looked around.'
kunya pi lac-lac
they go looking-looking
'They went looking around.'

\subsubsection{Compound words}

A compound is a construction that has as its constituents two free forms which are closely linked phonologically and operate syntactically as a single word. It may have two nouns operating as a single noun:

$$
\text { usoq 'origin' asan 'source' usoq-asan 'original source' }
$$

It may have a verb and a noun acting as a verb:

$$
\begin{array}{lllll}
\text { suka 'to like' } & \text { hati } & \text { 'heart' } & \text { suka-hati } & \text { 'to be glad' } \\
\text { sakëq 'be sick' } & \text { gigi } & \text { 'teeth' } & \text { sakëq-gigi } & \text { 'have toothache' }
\end{array}
$$

It may have two verbs linked to give a broader meaning:

pecah 'be broken' belah 'be split' pecah-belah 'be widely scattered'

These contrast with word clusters which are not closely linked phonologically, with each word retaining its own word stress. Some typical noun clusters follow:

$$
\begin{array}{ll}
\text { General + specific } & \begin{array}{l}
\text { kapan Matang 'ship Matang' } \\
\text { anak kuli 'son + coolie' }=
\end{array} \\
\text { prahu pukac 'boat + net' }= & \text { 'coolie' } \\
\text { Related words } & \begin{array}{l}
\text { laki bini 'husband + wife' }= \\
\text { Title + name }
\end{array} \\
\text { nabi Noh 'prophet Noah' } & \\
\text { Noun + verb } & \text { urak penyuri 'man thief }=\text { 'thief }
\end{array}
$$

In the last example, the word /penyuri/ has a nominal prefix, but it does not stand alone as a noun meaning 'thief; it is always used in a noun cluster: /urak penyuri/ 'man thief. In this it follows the pattern of /urak kebut/ 'gardener' and /urak lawoc/ 'men sea' = 'Sea People'. In Malay, the cognate word <pencuri> would be used alone, meaning 'thief. 


\subsection{Function of the word}

\subsubsection{Determination of word classes}

As Urak Lawoi' is closely related to Malay and has also been influenced by Thai, some modern descriptions of word classes in those two languages have been studied to help determine the criteria to be employed in deciding word classes in Urak Lawoi'. Writers consulted have included Payne (1970) and Abdullah Hassan (1974) for Malay, and Noss (1964) and Vichin (1970) for Thai. The study of these writers has shown that Urak Lawoi' follows its own individual pattern and it does not agree with either of these languages at every point.

An UL word stem in isolation has no inherent markers showing its word class, such as the obligatory inflections of Latin or Greek. When a prefix is added to a stem, the class of the resultant word becomes evident, e.g. /curi/ 'to steal' may be an adverb/curi/'secretly', or it may become a verb /menyuri/ 'steals', or a noun /penyuri/ 'a thief'. So /kilas/ can function as a noun, meaning 'windlass' while /mengilas/ is marked out as a verb meaning 'to haul in'. /melaw/ is a verb meaning 'to speak', while /permelaw/ is a noun meaning 'a word'. But when UL is compared with Bahasa Malaysia, it is evident that it has a much smaller inventory of affixes, and that these are used much less frequently than the corresponding affixes in that language. In the 2555 clauses of the UL corpus, there are only 441 occurrences of words with prefixes, so that there are comparatively few places where the prefix acts to identify the word class.

Nouns may be identified by their collocation with certain determiner particles as described in Section 3.2.2.1. Similarly, verbs may be identified by their collocation with certain verbal particles (Section 3.2.2.2). But words can only be positively assigned to a particular word-class as they occur in syntactic constructions. When a word occurs in isolation it is more appropriate to refer to it as a stem. In some cases its word class may be deduced from its meaning, but this may vary when it is used in a sentence. So /jalat/ has the potential of functioning as a noun or as a verb. In the sentence /nya turoc jalat itu/ 'he followed that path', /jalat/ functions as a noun. In the sentence /nya jalat pi kaq Raway dah/ 'he walked to Rawai', it functions as a verb.

Therefore dictionary entries must show the word class and meaning for each syntactic structure in which the word may function. Examples of such dictionary entries will be given in Section 3.2.3.

As in Malay and Thai, adjectives are regarded as a sub-class of the verb (Section 3.2.2.2.1). Adverbs are seen as a separate word-class (Section 3.2.2.3). This gives three major word classes of nouns, verbs and adverbs. The words in these classes are largely meaning-specific, with a large inventory of nouns and verbs. The inventory of vocabulary for adverbs is not so large, but has the potential for expansion. The number of occurrences of each of these words in my corpus is comparatively small, except for a few words of common occurrence, such as /pi/ 'go' and /maräh/ 'come'.

In contrast to these three major word classes is the word class of functors, which includes all particles, and all words not included in the three major word classes. Functors are largely function-specific with a comparatively small inventory of items in each sub-class, so that the total number of different functors in my concordance of approximately 1000 words is only 159 , not 
including exclamations or Malay loan-words. With the exception of the sub-classes of classifiers and exclamations, the words in each sub-class constitute a closed class, with no apparent possibility of expansion. Further, these words occur in text much more frequently than words of the three major classes. For instance there are only seven UL personal pronouns, as listed in Section 3.2.2.4.1, but those seven words occur 1424 times in the 2555 clauses of my corpus.

The functors of UL together form the skeletal structure of the language. For someone wishing to study this language they constitute a basic core of essential vocabulary, which can be supplemented with words chosen from the inventories of nouns, verbs and adverbs, according to the subject under discussion.

This analysis follows that of Fries who analysed English in terms of four major word classes, plus 15 groups of function words (Fries 1952:104-109, 278-296).

\subsubsection{Description of the word classes}

\subsubsection{Noun word class}

Noun word class is made up of nouns (nn), which function as fillers of the head slot in the Noun Phrase. They may be identified by their collocation with the determiner particles /ini/ 'this' and /itu/'that', which occur in the final marker slot of the noun phrase (Section 3.2.2.4.7).

$$
\begin{array}{lll}
\text { Noun phrase: } & \text { urak ini } & \text { 'this man' } \\
& \text { barak itu } & \text { 'those goods' }
\end{array}
$$

For lexical purposes the nouns are identified as common nouns animate (nca), common nouns human (nch), common nouns inanimate (nci), abstract nouns (nab), proper nouns locational (npl) and proper nouns personal (npp). This anticipates the need for differentiation as to which types of noun can occur in certain tagmemic slots. For instance, only nch and npp nouns could occur as subject of a verb of saying and perceiving (vsp).

Nouns differ in terms of the type of numerical classifier which is used with them:

1. Nouns, with a generic classifier; e.g. /urak/ 'person', used as a classifier for people; /semiya sepuloh urak/'men ten persons' = 'ten men'.

2. Mass nouns, using units of measure as a classifier; e.g. /kilo/ 'a kilogram'; /calok/'a tin'; /ayë se-calok/ 'water one tinful' = 'a tinful of water'.

3. Self-classifier, using the noun itself as its own classifier; /sawoh pac sawoh/'anchors four anchors' $=$ 'four anchors'.

4. Uncountable words such as /lawoc/'sea', which have no classifier.

\subsubsection{Verb word class}

The verbs (vb) function in the head slot of the verb phrase, and are identified as verbs by the particles associated with them. There are five auxiliary particles which immediately precede the verb: /phakhac/ and /khac/ 'collectively', /naq/ expressing future or intention, similar to the English 'will', /tengah/ 'in the middle of and /ada/ 'in the state of. The first two are always 
auxiliary particles so give an infallible indication that the following word is a verb. /naq/ has a homonym/naq/ 'of', a particle indicating possession, so the meaning of a phrase has to be known to determine which meaning of /naq/ is relevant; e.g. /aki naq ku/ 'husband of mine' as against Maki naq pi/ 'husband will go'. The word /tengah/ only occasionally functions as an auxiliary particle. It more commonly occurs as a preposition, /tengah/ 'in the middle of'; e.g. /dëq tengah lawoc/ 'in the middle of the sea', as against /nya tengah tinoq/ 'he is sleeping'. /ada/ normally occurs as an action verb meaning 'have, be at, exist' and followed by a noun. Its occurrence as an auxiliary particle is rare. So these five particles will identify the following word as a verb, provided the meaning is appropriate. In the following examples the particle and verb are highlighted.

kunya phakhac lari
they together run
'They are running'
koq nanaq khac menari
the children together are dancing
'The children are dancing'
nya naq pi kaq lawoc
'He will go to sea'
nya suka naq budö
'He likes to be stupid'
nya tengahterbëq dëq lubak
'He is coming out of the hole'
ada dudoq pëq itu lama-lama
was staying there a long while
'He stayed there a long while'

There is also a verbal particle /dah/ 'past indicator', which occurs clause finally, of ten with the object and adjuncts separating it from the related verb, so it is not as reliable a test as the auxiliary particles described above. If it appears in a minimal sentence without any object or adjuncts, and the meaning is appropriate, the word immediately before/dah/ is a verb; e.g. /nya pi dah/ 'he go past' = 'He went'.

\subsection{Action and adjectival verbs (vac and vaj)}

There are two main sub-classes of verbs, the action verb (vac), and the adjectival verb (vaj). The action verb occurs as the head of the verb phrase in an action clause, while the adjectival verb functions as the head of the verb phrase in a stative clause, as the modal auxiliary in a verb phrase, or as the modifier in a noun phrase. The action verb includes the intransitive verb (vaci), the transitive verb (vact), the bi-transitive verb (vacbt), and the verb of saying or perceiving (vsp).

vaci: nya tengah tinoq

'He is sleeping' 


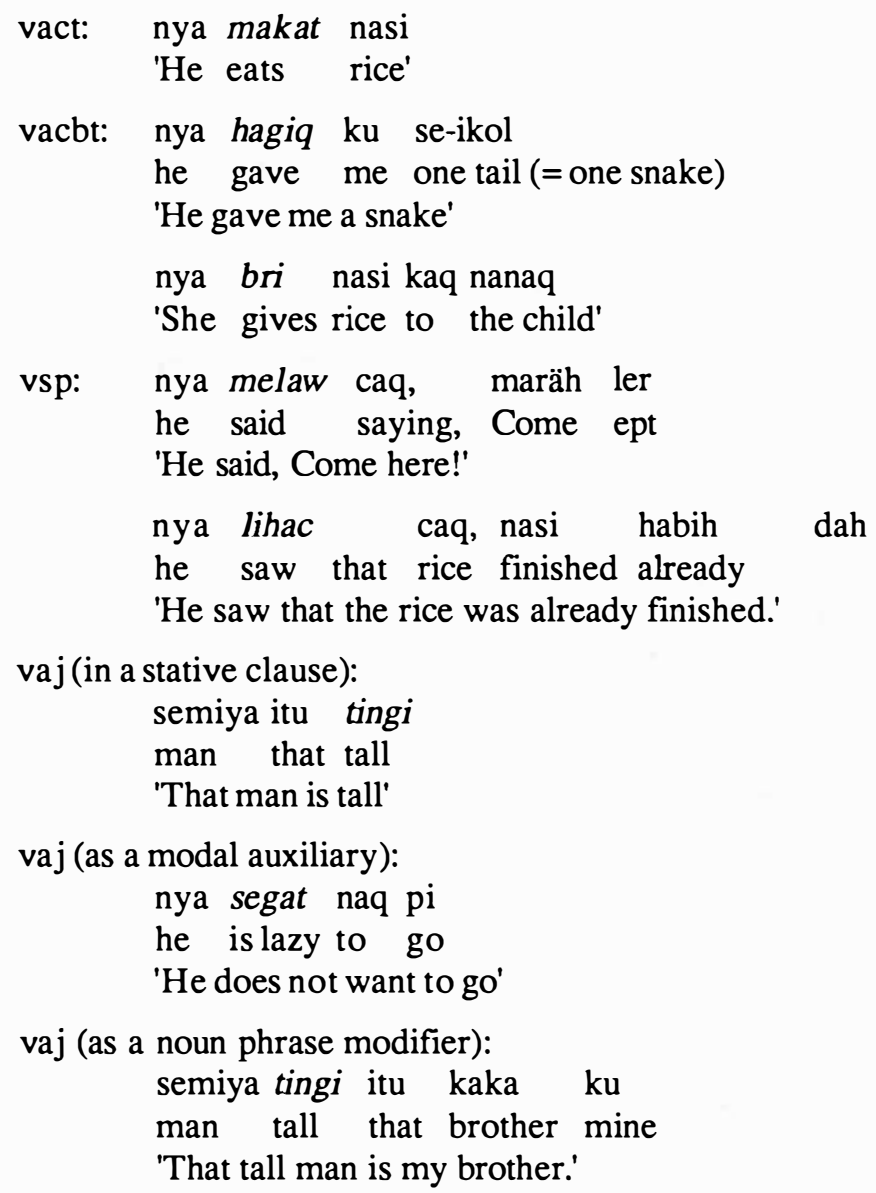

\subsection{Copulative verb (vcop)}

There is also a small sub-class of copulative verbs (vcop) which occur as the filler of the optional verb slot in the equative clause. The main verb of this sub-class is /jadi/ 'to be, to become', with its inflected form /mejadi/ 'becomes'. This verb is used with other related meanings, but its use as a copula is distinguished by its being preceded by a subject and followed by a complement with the same referent. Also, the copula can of ten be omitted with no change in the meaning of the clause.

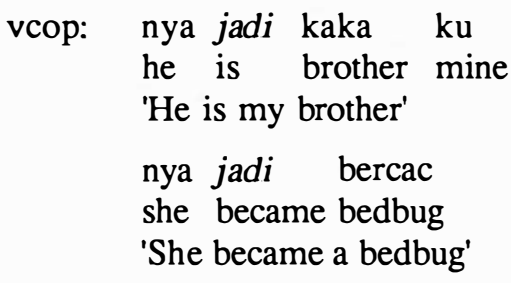


$\begin{array}{ll}\text { setengah } & \text { mejadi tupay } \\ \text { 'Some } & \text { became squirrels.' }\end{array}$

Of these examples the first is the only one where the copula verb can be omitted. If it is omitted, a syntactic particle /ter/ would be inserted after the subject/nya/, as UL seems to avoid a mono-syllabic subject, where there is an adjectival verb or no verb.

vcop (with verb omitted):

nya ter kaka ku

he spt brother mine

'He is my brother.'

In Malay, the word <ada> 'be, exist, be present' is stated to be a copula (Abdullah 1974:22), but in UL, the word /ada/ means 'to have, to exist, to be there', and is not used as a copula. It occurs as an introductory verb equivalent to the English 'there is, there are', and is often followed by the emphatic particle /ler/: /ada ler buwah/ 'There was fruit'. This can only be regarded as a copulative verb if it is assumed that a subject equivalent to 'it' or 'they' has been deleted, but there is no evidence for such a subject. /ada/ has as one of its meanings 'to be there'. This is authenticated by one text where an elderly UL lady gives an excited acount of her visit to the zoo in Bangkok. She lists some of the animals she saw there in the formula /brutat ada/ 'tiger was there'. In view of this example, /ada/ in the introductory clause is regarded as an action verb, with the verb brought to the front of the sentence for emphasis:

ada ler koq hatu ter; nya menupak

are ept the spirits spt; they dwell (in men)

'These are the spirits who dwell in men.'

ada ulal se-ikol; nya ada dëq atas dah ter

is snake one-tail it is on above vpt spt

'There is a snake that is above (in the tree).'

In Malay, the subject of the second clause in sentences like this is omitted, with the /hatu/ of the first sentence, and the /ulal/ of the second sentence, acting as the subject of the second clause (Lewis 1969:148). This is different to UL, where a pronoun occurs as the subject of the second clause.

\subsubsection{Adverb word class}

The adverbs (av) can function in one of the adjunct slots which occur clause-initially and clause-finally at clause level. They include adverbs of time (avt), location (avl), manner (avm), extent (ave), accompaniment (ava), and interrogation (avq):

$\begin{array}{lllllll}\text { avt: } & \text { nya } & \text { pi } & \text { kemari } & \text { avl: } & \text { nya pi jawoh } \\ & \text { 'He } & \text { went } & \text { yesterday' } & & \text { 'He went far' } \\ \text { avm: } & \text { nya } & \text { pi } & \text { cepac } & \text { ave: } & \text { ada } & \text { banyaq } \\ & \text { 'He } & \text { went } & \text { quickly' } & & \text { There were many' }\end{array}$




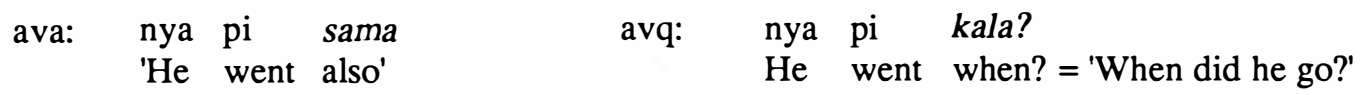

A limited number of adverbs also appear between the subject and the predicate, and have been interpreted as filling an adjunct slot which is the first slot in the pre-nuclear periphery of the verb phrase (Section 4.1.2.2.2).

nya curi amët barak itu pi

he secretly took goods that go

'He secretly took the goods away'

nya gasaq ikac kuni

He vigorously tied sack

'He vigorously tied the sack'

The adverbs are not a large word-class, but are an open class as many verbs can be reduplicated to become an adverb: e.g. /unol/ 'to retreat', /nol-unol/ 'retreating' (Section 3.1.3.2).

The sub-class of interrogative adverbs is a closed class with only four members: /brapa/ 'how many?', /diha/ 'where?', /kala/ 'when?', and /kaqhami/ 'how?'.

\subsubsection{Functor word class}

The status of the functors is described in Section 3.2.1. They are divided into functor words and functor particles, on the basis of whether they can stand alone in free form or not.

The twelve sub-classes of functors are listed below. The number assigned to each sub-class corresponds with the number of the sub-section which describes that sub-class.
1. Pronouns
7. Noun phrase particles
2. Classifiers
8. Verb phrase particles
3. Numerals
9. Prepositions
4. Auxiliary verbs
10. Conjunctions
5. Responses
11. Interrogative particles
6. Negatives
12. Exclamations

Functor words in Sub-classes 1-4 refer to a relevant noun or verb, explicit or unexpressed, for which they may function as a lexical substitute. Sub-classes 5 and 6 are exhortations, affirmations and negations associated with verbs. In some cases they may stand alone as the answer to a question, reflecting the meaning of the Head verb.

The functor particles in Sub-classes 7 - 11 are largely operational words, indicating syntactic functions and categories. They have little or no lexical meaning, and do not derive any meaning from the words with which they are associated.

$$
\begin{aligned}
& \mathrm{ku} \text { naq pi kaq lawoc } \\
& \text { 'I will go to sea' }
\end{aligned}
$$


Here the functor word $/ \mathrm{ku} /$ is a pronoun referring to the speaker. The functor $/ \mathrm{naq} / \mathrm{is}$ a verbal particle signalling futurity or intention. The particle $/ \mathrm{kaq} /$ is a preposition signalling 'motion towards'. The two particles cannot stand alone, but the functor word $/ \mathrm{ku} / \mathrm{can}$ stand alone as the answer to a question, with the verb inserted optionally.

Question: sapa naq pi kaq lawoc? 'Who will go to sea?'

$\begin{array}{lll}\text { Answer: } & \mathrm{ku} & \text { (naq pi) } \\ & \mathrm{I} \quad(\text { will go)' }\end{array}$

A similar pattem is seen with an auxiliary verb functor:

$\begin{array}{llll}\text { Question: } & \text { kaw belëh pi ger? } & \text { Answer: } & \text { belëh } \\ & \text { you can go qpt } & & \text { can } \\ & \text { 'Can you go?' } & \text { 'I can' }\end{array}$

In this question, the functor /belëh/ is an auxiliary verb, preceding the head verb of the verb phrase /pi/ 'go'. In the answer the auxiliary stands alone as the head of the verb phrase, and refers to the head verb in the question. In contrast:

$\begin{array}{llll}\text { Question: } & \text { kaw naq pi ger? } & \text { Answer: } & \text { naq pi } \\ & \text { you will go qpt } & & \text { will go } \\ & \text { 'Will you go?' } & \text { 'Yes, I will' }\end{array}$

Here /naq/ is an auxiliary particle which cannot stand alone as the answer to the question, so that /pi/ has to be repeated as the head verb in the answer.

3.2.2.4.1 Pronouns (pn): These are functor words which operate as fillers of the head slot and other slots in the noun phrase, but with restrictions on the tagmemes which can co-occur with them, as described in Phrase Level (Sections 4.1.1.2, 4.1.1.3). There are five sub-groups: personal pronouns (ppn), indefinite pronouns (ipn), interrogative pronouns (qpn), demonstrative pronouns (dpn), and relative pronouns (rpn). These constitute small closed classes and so are listed in full.

\section{Personal pronouns (ppn):}

$\begin{array}{lcl}\text { Person: } & \text { Singular: } & \text { Plural: } \\ \text { 1st (excl) } & \text { ku } & \text { kami } \\ \text { 1st (incl) } & - & \text { kita } \\ \text { 2nd } & \text { kaw } & \text { kanyaw } \\ \text { 3rd } & \text { nya } & \text { kunya }\end{array}$

Of these, /nya/ is the most common with 849 occurrences in the computer text, compared with 575 occurrences for all the other personal pronouns combined.

The personal pronoun /aku/ occurs once in place of $/ \mathrm{ku} /$, but this is regarded as a Malay loan word.

Indefinite pronouns (ipn): These are pronouns expressing an indefinite quantity. They fill one of the quantifier slots or the head slot in the noun phrase (Section 4.1.1) or the extent adjunct slot at clause level. 
Some indefinite pronouns are as follows:

$\begin{array}{llll}\text { banyaq } & \text { 'many' } & \text { bilak } & \text { 'each' } \\ \text { dikiq } & \text { 'a little' } & \text { lumöh } & \text { 'group' } \\ \text { nama } & \text { 'anything' } & \text { rata } & \text { 'every' } \\ \text { semuha } & \text { 'all' } & \text { setengah } & \text { 'some' } \\ \text { sik-masik } & \text { 'each one' } & & \end{array}$

Interrogative pronouns (qpn): There are only three words in this sub-class. They may fill the head slot in the noun phrase (Section 4.1.1.2.1), or may operate as indefinite pronouns with the alternate meaning shown below.

$\begin{array}{ll}\text { apa } & \text { 'what? } \text { whatever' (MLW) } \\ \text { nama } & \text { 'what? whatever' } \\ \text { sapa } & \text { 'who? whoever' }\end{array}$

Demonstrative pronouns (dpn): There are three words in this category: /ini/ 'this', /itu/ 'that', and /singi/ 'that just now'. These words function as demonstrative pronouns in the head slot of the noun phrase (Sections 4.1.1.2.1, 4.1.1.3). They have homonyms which are determiner particles in the final marker slot of the noun phrase (Section 3.2.2.4.7). Examples of the demonstrative pronouns are as follows:

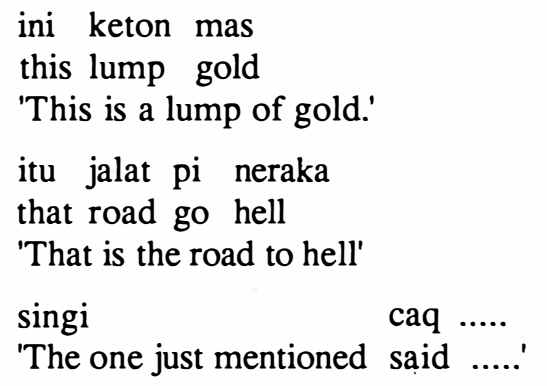

Relative pronoun (rpn): There is only one word in this sub-class, the pronoun /nu/ 'who, which, what/. This has a dual function, operating as head of the noun phrase when it is subject of an embedded noun clause, and also acting as the conjunction which links that embedded clause with the noun to which it relates. As it cannot stand alone as an utterance, it is classified as a particle, but in filling the head slot of a noun phrase it operates as a word (Section 3.2.2.4.10).

$$
\begin{aligned}
& \text { nanaq nu adi bermaräh } \\
& \text { child who younger comes } \\
& \text { 'The younger child is coming' }
\end{aligned}
$$

\subsection{Classifiers (cl)}

These are words which function as the filler of the head slot in the noun phrase, or which combine with a numeral to fill one of the quantifier slots in that phrase (Section 4.1.1.2, 4.1.1.3). There are two sub-classes, the numerical classifier $(\mathrm{cln})$ and the metric classifier (clm). 
The numerical classifier (cln) is used for a wide range of nouns which sometimes have little apparent connection between them. Metric numerical classifiers (clm) are various units of weight, volume, length, time, et cetera, which function with related nouns. As described in Section 3.2.2.1, some nouns use a repetition of themselves as a self-classifier, and some have no classifier at all. In Urak Lawoi' the use of these classifiers is decreasing, compared with their use in Malay and Thai. Some representative classifiers are as follows, with their literal meaning as shown:

Cln: $\quad$ Types of objects:

batak poles, masts, etc.

belah sides

biji small objects

buwah large objects

ikol animals, birds, fish

keton lumps of anything

krac pieces of cloth

lamal sheets of paper, cloth, leaves

puhot trees and shrubs

tepac places

urak people

Clm: Meaning:

batën 'a dipper'

calok 'a milk tin'

depa 'a fathom'

kilo 'a kilogram'
Example:

tujoh batak phahadak 'seven poles protecting' urak belawat duwa belah 'men contesting two sides' crana tiga biji 'trays three seeds' rumah duwa buwah 'houses two fruit' penyu duwa ikol 'turtles two tails' mas duwa keton 'gold two lumps' kayët duwa krac 'cloth two pieces' surac duwa lamal 'letters two sheets' kelamël duwa puhot 'coconuts two trees' kramac duwa tepac 'shrines two places' kita duwa urak 'we two persons'

Example:

ayë sa batën 'water one dipper' ayë sa calok 'water a tinful' lima belas depa 'fifteen fathoms' bras lima kilo 'rice five kilograms'

3.2.2.4.3 Numerals (num): These are words which, either alone or in combination with a numerical classifier, fill either of the quantifier slots in the noun phrase (Sections 4.1.1.2.2, 4.1.1.2.5). Those listed comprise the complete set of UL numerals. They may be combined as shown in the examples below:

\begin{tabular}{llll} 
sa $\sim$ se- & 'one' & nam & 'six' \\
duwa & 'two' & tujoh & 'seven' \\
tiga & 'three' & lapat & 'eight' \\
pac & 'four' & semilat & 'nine \\
lima & 'five' & se-puloh & 'ten' \\
belas & 'plus ten' (for numerals 11 to 19) & \\
puloh & 'multiply by ten' (for numerals 10 to 90) \\
ratus & 'multiply by 100' (for numerals 100 to 900) \\
ribu & 'multiply by 1000' (for numerals 1000 to 9000) \\
laqsa & \multicolumn{2}{l}{ 'ten thousand; an indefinitely large number' }
\end{tabular}




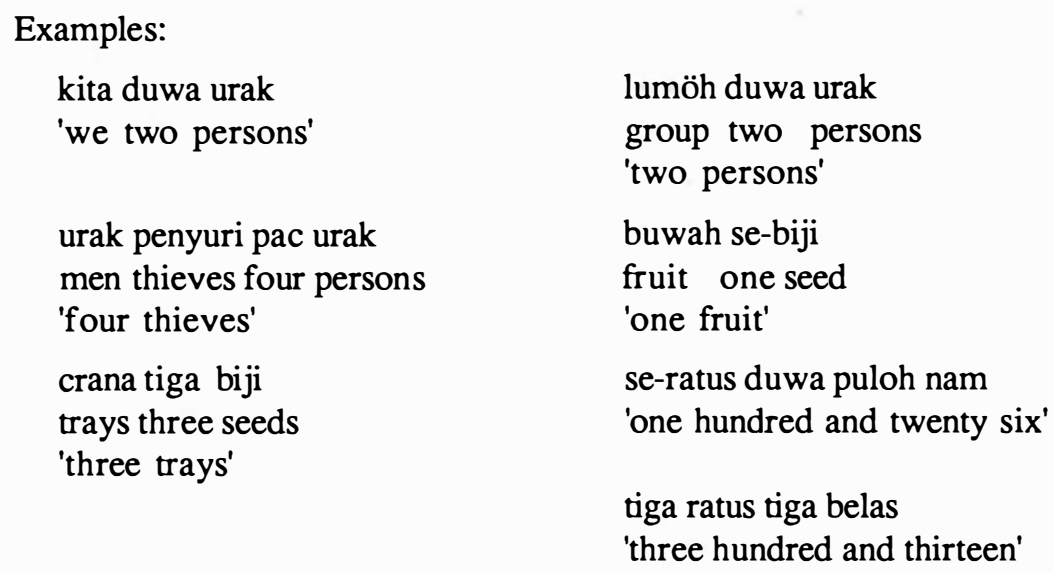

3.2.2.4.4 Auxiliary verbs (vaux): Auxiliary verbs are verbs which function in the modal auxiliary slot in the verb phrase. Some of them also function as action verbs with slightly different meaning. Some are listed below, showing their meaning as an action verb, and as an auxiliary verb.

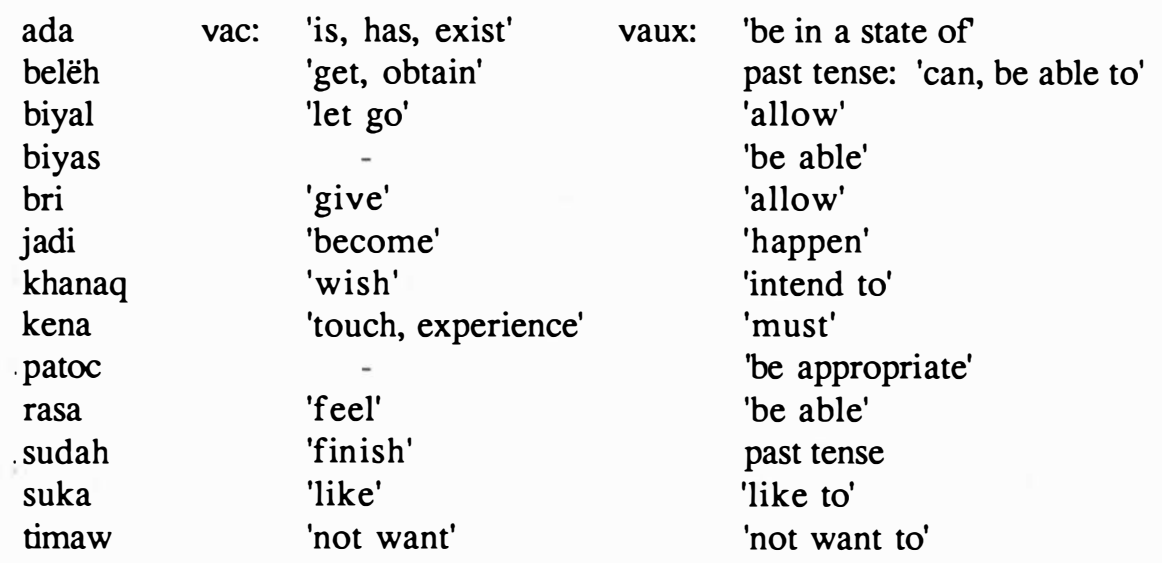

As explained above in Section 3.2.2.4, these words can be used as the sole answer to a question.

3.2.2.4.5 Response words (res): This is a small group of words which occur sentence initially, either evoking a response, as in a command or exhortation, or else expressing a response to a question, command or exhortation. Only the words /böh/ and /joh/ can function in both categories. /bri/ and /jangan/ can function in a command or exhortation but not in a response. /er/, /hoy/ and /bukat/ can only function in a response.

/böh/ is equivalent to 'right' in English in both these contexts. It is an exhortation to do something in which the speaker will not participate: 
In exhortation: böh, bri kaw amët ler right, let you (sg) take ept 'Right, you take it.'

In answer: $\quad$ böh; kami naq pi 'Right; we will go.'

/joh/ occurs sentence-initially as the first word in an exhortation to do something in which the speaker will participate or as the response of those who will participate:

In exhortation: joh, bri kita pi tulok right, let us go help

'Right, we will go.'

In response: joh, kita naq pi

'Right, we will go.'

/bri/ is similar to/böh/in that it occurs initially in an exhortation, sometimes with the meaning 'let ....'. There is no indication as to whether the speaker will participate or not, and it does not occur in response to an exhortation. It can also occur preceded by the response words /böh/, /joh/ or /jangan/. It is unique among the response words in that it can be followed by the subject of the clause. This contrasts with the other response words which have the subject of the verb deleted in an exhortation, with a second person pronoun understood:

In exhortation: böh, bri kaw amët ler

right, let you (sg) take ept

Right, you take it.'

joh, bri kita pi tulok

come, let us go help

'Come, let us go and help.'

jangan bri kita pi soq itu

don't let us go place that

'Don't let us go there.'

bri usiq koq brana

let play the drums

'Play the drums.'

/jangan/ is a verbal auxiliary which functions as a response word 'don't', occurring sentenceinitially in a negative command. It does not occur in response to an exhortation.

In command: jangan naq pi lah don't will go ept

'Please, don't go.'

/er/ is equivalent to 'yes' in English, and is used sentence-initially only. It has a homonym in the emphatic particle /er/, which occurs phrase-finally in the vocative phrase of an imperative clause. 


$$
\begin{array}{ll}
\text { In answer: } & \begin{array}{l}
\text { er; ada bras genaq dah } \\
\text { yes, have rice enough vpt } \\
\text { 'Yes, there's enough rice.' }
\end{array} \\
\text { In command: } & \begin{array}{l}
\text { koq nanaq er; bediri ler } \\
\text { the children ept; stand ept }
\end{array} \\
& \text { 'Children! Stand up!' }
\end{array}
$$

/hoy/, /tët/ and /bukat/ are response words which occur sentence-initially as a negative answer to a question or statement. /hoy/ has the meaning 'no, have not', /tët/ means 'no', while /bukat/ means 'no, is not', with the implication that the opposite is true. These words also function as negative words as described in the next sub-section.

$\begin{array}{ll}\text { In answer: } & \text { hoy; tët jadi baliq } \\ & \text { no; not happen return } \\ & \text { No, he did not return.' } \\ & \text { bukat, nya dudoq Raway } \\ & \text { no, he lives Rawai } \\ & \text { No, he lives at Rawai' }\end{array}$

3.2.2.4.6 Negatives (neg): A small group of words is used to negate a statement, or may occur as the negative answer to a question.

/tët/ here functions as a negative preceding a verb, and occurring in the Adjunct slot of the verbal phrase (Table 4-2, Section 4.1.2.1). This negative occurs frequently before the verbal auxiliary /belëh/, of ten with inversion to the end of the clause. In this some speakers follow a Thai syntactical pattem with /tët belëh/ before the verb indicating past tense, while when inverted to the end of the sentence it means 'cannot, is not able to'.

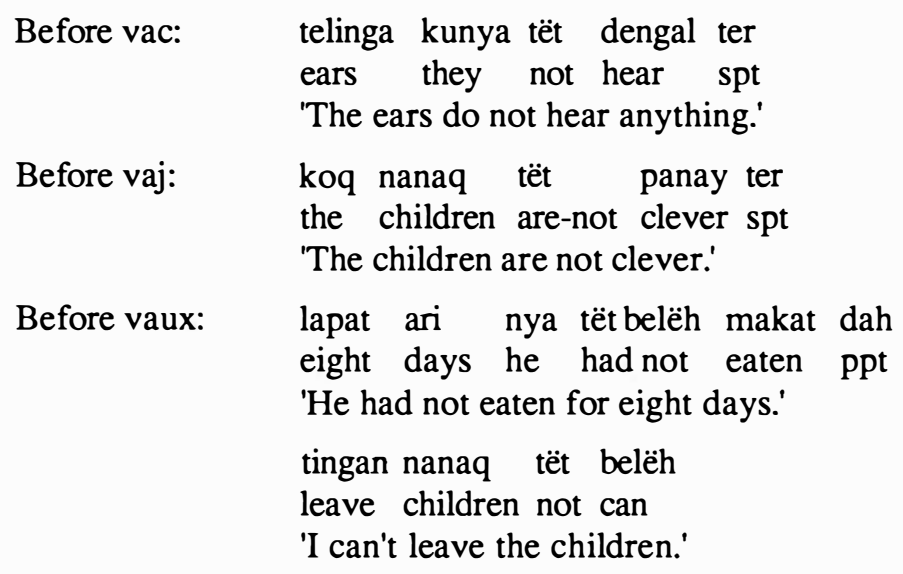

/hoy tët/'not, have not' is a more emphatic negative than /tët/, and precedes the verb in the same way. 


\begin{tabular}{|c|c|}
\hline Before vac: & $\begin{array}{l}\text { hoy tët baliq lagi } \\
\text { has not return yet } \\
\text { 'He has not yet returned.' }\end{array}$ \\
\hline Before vaj: & $\begin{array}{l}\text { hoy tët senang pot } \\
\text { is not well spt } \\
\text { 'He is not at all well.' }\end{array}$ \\
\hline Before vcop: & $\begin{array}{l}\text { buwah nya hoy tët jadi ler } \\
\text { fruit it has-not become ept } \\
\text { 'It has not yet borne fruit.' }\end{array}$ \\
\hline Before vaux: & $\begin{array}{l}\text { hoy tët belëh naq taroh ter } \\
\text { has not able to place spt } \\
\text { 'He has not been able to place it.' }\end{array}$ \\
\hline
\end{tabular}

The response words /hoy/ and /bukat/ also function as a verb with a negative meaning 'is not'. In this they act as the negative equivalent of the verb /ada/ when it means 'to be, to exist'. In this function /hoy/ is a direct negative while /bukat/ has the further implication that the opposite is correct.

$$
\begin{aligned}
& \text { hoy ayë } \\
& \text { is not water } \\
& \text { 'There is no water.' } \\
& \text { hoy nama naq makat } \\
& \text { is not anything to eat } \\
& \text { 'There is nothing to eat.' } \\
& \text { nya bukat urak soq ini } \\
& \text { he not man side this } \\
& \text { 'He is not a man from here.' } \\
& \text { bukat nu mudah ter } \\
& \text { not what is easy spt } \\
& \text { 'It is not something easy.' }
\end{aligned}
$$

/timaw/ 'not want to', was listed above as an auxiliary but is mentioned again here because it can function as the negative answer to a question. It is cognate to the Malay <ta' mau > not want to', but there is no UL cognate to the Malay verb < mau > 'want to'.
As vac: ku timaw laki ulal kaqgini
I not-want husband snake like-this
'I don't want a snake as a husband.'

As vaux: nya timaw naq tinoq

he not-want to sleep

'He does not want to sleep.' 
3.2.2.4.7 Noun phrase particles: There are four types of particle in the noun phrase: the determiner particle (dpt), the syntactic particle (spt), the emphatic particle (ept), and the initial determiner particle (dpti). The last-named appears in the initial marker of noun phrase type $\mathrm{NPb}$ (Section 4.1.1.3), while the first three may appear finally in any noun phrase, subject to the restrictions on the determiner particle set out in the sub-section on determiner particles below. When two or three of these particles occur phrase-finally, they occur in the order (dpt $+\mathrm{spt}+\mathrm{ept}$ ). The syntactic particle/pot/always occurs alone. The syntactic and emphatic particles may also function in the clause-final Coda (Section 4.1.4).

A brief statement of the formulae of the two types of noun phrases is set out below. The full formulae and a guide to the abbreviations can be seen in Table 4-1 (Section 4.1.1).

$$
\begin{aligned}
& \mathrm{NPa}= \pm \text { Qn } 1:+\mathrm{H}: \pm \text { Mod: } \pm \text { Pos: } \pm \text { Qn2: } \pm \text { Mf: }( \pm \mathrm{dpt} \pm \text { spt } \pm \text { ept }) \\
& \mathrm{NPb}=+ \text { Mi:dpti }+\mathrm{H}: \pm \text { Mod: } \pm \text { Pos: } \pm \text { Mf: }( \pm \mathrm{dpt} \pm \text { spt } \pm \text { ept })
\end{aligned}
$$

Determiner particles (dpt): The determiner particles are /ini/ 'this', /itu/ 'that', /ni/ 'this' and /singi/ 'that just now'. As explained above, homonyms of /ini/, /itu/, and /singi/ operate as demonstrative pronouns but they occur more frequently as determiner particles. When the initial determiner particle / koq/ or / koq lumöh/ occurs in the noun phrase, the particles /ini/ and /itu/ do not normally appear. These two particles appear in the noun phrase marker only, but /ni/ and /singi/ can also appear with similar meaning in the final coda of the clause, where they function as syntactic particles as described immediately below and in Section 4.1.4. The particle /ni/ is similar to the Thai word for 'this', but without the tone. When used in the final phrase marker, it has more emphasis than /ini/, as if saying 'this house, not that one'. The particle/singi/'that just now' is equivalent to the Malay <tadi>, and refers back to something just mentioned, or that has just happened.

$\begin{array}{ll}\text { rumah besal ini } & \text { rumah besal itu } \\ \text { house big this } & \text { house big that } \\ \text { 'this big house' } & \text { 'that big house' } \\ \text { rumah besal ni } & \text { hurak singi } \\ \text { house big this } & \text { lobster just-now } \\ \text { 'this big house (not that one)' } & \text { 'the lobster just mentioned' }\end{array}$

Syntactic particles (spt): There are two syntactic particles in the UL noun phrase: /ter/ and /pot/. It is difficult to assign a lexical meaning to these two words as they operate as a verbal comma rather than as a word. They mark the end of the noun phrase and are pronounced with a non-final upward intonation followed by a slight pause. In this way they signal that there is something still to be mentioned. They appear similarly at the end of a non-final clause. When they appear at the end of a sentence they signal that the subject is not finished - there is more to follow. The particle /pot/ has more emphasis than /ter/ but not as much as the emphatic particle/ler/.

Both /ter/ and /pot/ frequently occur at the end of a noun phrase in the subject position, if the subject is brief or mono-syllabic. In this position Malay students have called it a balance word; e.g. Winstedt describes Malay <pun>, the cognate of /pot/, as "an enclitic (not of ten to be translated) emphasizing the word before it or to balance the sentence." (Winstedt 1972:281). 
When there is a listing of a group of nouns or noun phrases, /ter/ is sometimes used to mark them off from one another. /ter/ is also used phrase-finally to mark the end of a topic, or to mark the end of a phrase brought to the front of a clause for emphasis.

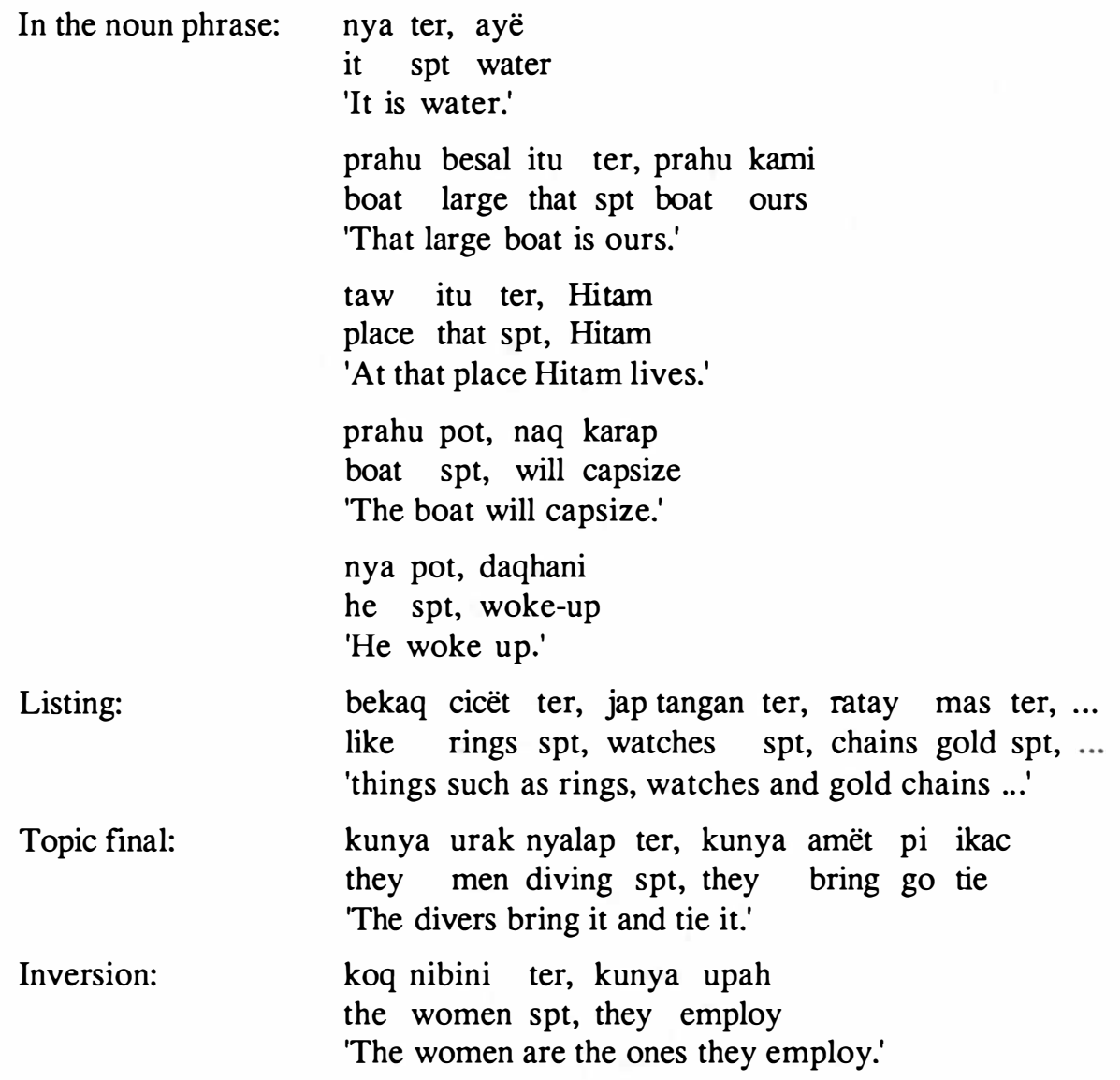

This last example could be read as having an initial topic 'The women they employ'. However, /upah/ requires an object, and in the absence of any other object /koq nibini/ is read as an object brought to the front of the sentence for emphasis.

The syntactic particles also occur in the clause-final coda, signalling the end of the clause, and indicating that there is something still to be said (Section 4.1.4). In this use it is common at the end of a relative clause, or other subordinate clause. Two or more parallel clauses may be linked by clause-final /ter/. Clause-finally, /ni/ and /singi/ function as syntactic particles rather than as determiner particles. In this context their meaning is /ni/ 'like this' and /singi/ 'like that', and they function to mark the end of a causal clause, pointing on to the following result clause.

Clause final: kaq kaw melaw kaqhami pot, ku timaw if you say whatever spt, I don't-want Whatever you say, I won't agree.' 
kunya naq menikah ter, kunya buwac crana duhulu they will marry spt, they make wedding-trays first 'When there is a wedding, they first prepare the trays of wedding gifts.'

kaq sakëq gigi ter, makat ubac thanjay if sore teeth spt, eat medicine Thanjay

'If they have toothache, they take the medicine 'Thanjay'.'

ada semiya nu sakëq ter ...

is man who sick spt ...

'There is a man who is sick.'

Causal clause and result:

kita hoy kerja ni; kita kena kerja ler

we have-no work like-this; we must work ept

'When we are out-of-work like this, we just have to work (at this dangerous task).'

kanyaw kerja dëq lawoc ni; belëh senang dah you work at sea like-this; can be-at-ease vpt 'When you work at sea like this, you can be at ease.'

tana tët biyas singi; koq nanaq lapal ler nasi dah when not able as-just-mentioned, the children hungry ept rice vpt 'When you cannot go fishing like that, then the children are really hungry for rice.'

Linking parallel clauses:
turot pahëq ter, banyaq puloh kaki ter, pahëq ter let-down drill spt, many tens feet spt, drilling-bit spt You let down the drilling-bit many tens of feet as you drill (in prospecting for tin).'

Emphatic particles (ept): The main emphatic particle is /ler/ which occurs finally both in the noun phrase final marker, and in the clause coda. In this it is of ten closely linked with the syntactic particle /ter/. It may also occur following other words to give them emphasis. Other particles which may operate in this way are /er/ which occurs after a vocative phrase in a command or exhortation, /lah/, the Malay cognate of /ler/, and the exclamation /ëq/ with its alternate forms /ëh/ and /äq/.

$\begin{array}{ll}\text { In noun phrase: } & \text { kita duwa urak ler } \\ & \text { we two persons ept } \\ & \text { kanyaw ler } \\ & \text { you ept } \\ & \text { certa itu ler } \\ & \text { story that ept }\end{array}$




$\begin{array}{ll} & \text { kunya ter ler } \\ \text { they spt ept } & \\ & \text { koq kilaki ter ler } \\ \text { the men spt ept } & \\ \text { paq dëq jakmiq ëq } & \text { father of Jakmiq ept } \\ \text { After vocative: } & \text { koq nanaq er; bediri ler } \\ \text { the children ept; stand ept } & \text { 'Children! Stand up!' } \\ \text { In clause coda: } & \text { nya buwac ler, buwac nasi bri } \\ & \text { he made ept, made rice for } \\ \text { 'He did it, he cooked rice for them.' } \\ \text { nu phakhac dudoq menyengöq ler } \\ \text { who together stay watching ept } \\ \text { '...the ones who stayed and watched ...' } \\ \text { ada ler ulal ter } \\ \text { is ept snake spt } \\ \text { 'There is a snake.' } \\ \text { nya lamac ler naq suq dah } \\ \text { he is-slow ept to finish vpt } \\ \text { 'He is very slow to finish it.' } \\ \text { kunya pi kaqgiter ler dah } \\ \text { they go like-that ept vpt } \\ \text { 'They just went like that.' } \\ \text { nya dudoq jawoh ler dëq nanggri dah } \\ \text { he lived far ept from city } \\ \text { 'He lived very far from the city.' } \\ \text { After adverb: }\end{array}$

Initial determiner particle (dpti): The only member of this sub-class is the particle /koq/ 'the', but it may occur closely linked with the indefinite numeral pronoun /lumöh/ 'group', in the phrase /koq lumöh/. This particle with or without the /lumöh/is the only filler of the initial marker slot in Noun Phrase type NPb. When the initial marker slot is filled, the determiner particles /ini/ 'this' and /itu/ 'that' do not normally occur in the noun phrase final marker.

This particle refers to something or someone that is old information and is used only with countable objects. In one text it occurs in a listing of various objects which are placed in the 'spirit boat' in the biennial spirit ceremony. Countable objects are prefixed by/koq/, but other objects are not. It frequently indicates that the subject is plural, especially in the PYP dialect. Sometimes it means 'the group of.

$$
\begin{array}{ll}
\text { Initial marker: } & \begin{array}{l}
\text { koq nanaq kita } \\
\text { the children (of us) }
\end{array}
\end{array}
$$




koq nibini ter
the women spt
koq semiya dëq lawoc
the men at sea
koq lumöh urak lawoc
the group Sea People
böh koq lada, pelacat, koq tepok, koq dët
place the chillies, fishpaste, the cakes, the candles
Listing: $\quad$ They place chillies, fishpaste, cakes and candles (in the boat)...'

3.2.2.4.8 Verb phrase particles: There are three sub-classes of particles appearing in the verb phrase, the modal particle (mpt) which appears initially in the pre-nuclear periphery of the verb phrase, the auxiliary particle (apt) which occurs finally in the initial periphery of the verb phrase, and the verbal particle (vpt) which occurs in the final periphery of the verb phrase. This last particle is functionally a part of the verb phrase but phonologically it forms part of the clause coda because it is of ten separated from the head verb by the object and adjuncts so as to form a discontinuous verb phrase.

A brief outline of the Action Verb Phrase is given below, showing where these particles occur. The full formula is found in Table 4-2, with abbreviations used and explanation set out in Section 4.1.2.1.

$$
\begin{array}{ccl}
\text { Pre-nuclear periphery } & \text { Nucleus } & \text { Post-nuclear periphery } \\
\text { VPac }= \pm \text { Adj:mpt } \pm \text { Maux:vaux } \pm \text { Aux:apt } & \pm \text { HV:vac } & \pm \text { Faux:vpt }
\end{array}
$$

In the examples in this section the verb phrase is highlighted.

Modal particles (mpt): There are only two modal particles, /bac/ expressing mild surprise or reproof, and /pah/ expressing intense desire.

$\begin{array}{ll}\text { bac: } & \text { nya bac timaw naq tinoq } \\ & \text { he mpt not-want to sleep } \\ & \text { 'He just did not want to sleep.' } \\ \text { pah: } & \text { nya pah lapal dah ler } \\ & \text { he very hungry vpt ept } \\ & \text { 'He was very hungry indeed.' }\end{array}$

Auxiliary particles (apt): There are only five auxiliary particles: /naq/ showing futurity or intention, similar to the English <will>; /phakhac/ and its abbreviation / khac/ speaking of collective action with various persons acting together; /tengah/speaking of an action as continuing in the present; and /ada/ speaking of a continuing state. These particles operate to identify words of the verb class, as described in Section 3.2.2.2.

$\begin{array}{lll}\text { naq: } & \mathrm{ku} \text { naq } & \text { pi mengayën } \\ & \text { 'I will } & \text { go fishing.' }\end{array}$ 


\begin{tabular}{|c|c|}
\hline phakhac: & $\begin{array}{l}\text { kunya phakhac pi buwac } \\
\text { they together go do } \\
\text { 'They go and do it together.' }\end{array}$ \\
\hline khac: & $\begin{array}{l}\text { koq nanaq khac menari } \\
\text { the children together are dancing } \\
\text { 'The children are dancing together.' }\end{array}$ \\
\hline tengah: & $\begin{array}{l}\text { nya tengah tinoq ni } \\
\text { 'He is sleeping like-this.' }\end{array}$ \\
\hline ada: & $\begin{array}{l}\text { kita ada bajiq } \\
\text { We are well.' }\end{array}$ \\
\hline
\end{tabular}

Verbal particles (vpt): There are seven final verbal particles which function in the final periphery of the verb phrase. They are located as the first element in the clause-final Coda (Section 4.1.4), so that if any object or adjuncts follow the verb, they separate these particles from the head verb. Five of these particles may optionally be followed by the particle/dah/, but these groupings have been interpreted as being a single filler in the first element of the Coda slot. Some of these particles also function as adverbs, so that it is sometimes difficult to know their function in a particular sentence. The particles are:

$\begin{array}{ll}\text { Particle: } & \text { Indicating: } \\ \text { bri } & \text { benefactive action on behalf of another } \\ \text { buwak (dah) } & \text { finality } \\ \text { dah } & \text { past or decisive action } \\ \text { habih (dah) } & \text { completed action } \\ \text { lepas (dah) } & \text { freedom from an undesirable state } \\ \text { suc (dah) } & \text { finished action } \\ \text { sudah (dah) } & \text { finished action }\end{array}$

In the following illustrations the verb phrase is highlighted:

bri:

$$
\begin{aligned}
& \text { nya naq buka bri } \\
& \text { he will open for } \\
& \text { 'He will open it for them.' } \\
& \text { nya buwac ler; buwac nasi bri } \\
& \text { he made ept, made rice for } \\
& \text { 'He did it, he cooked rice for them.' }
\end{aligned}
$$

buwak: nya pi buwak

he went finally

'He went and did not come back.'

nya turot cäw pi kaq tökkha buwak dah

he descended row go to Phuket finally vpt

'They got into their boat and rowed to Phuket.' 


$\begin{array}{ll}\text { dah: } & \text { hoy ikat dah } \\ & \text { are-no fish vpt } \\ & \text { There are no more fish.' } \\ & \text { kanyaw hoy semengac, kanyaw ke } \\ & \text { you have-no spirit, you m } \\ & \text { 'If you have no spirit, you must certainly die. } \\ & \text { hoy tët pi pëq diha dah } \\ & \text { did not go place wherever vpt } \\ & \text { 'He did not go anywhere at all.' } \\ & \text { nya tahu röc kaq nanggri dah ler } \\ & \text { he knew reach to town vpt ept } \\ & \text { 'It was known right to the town.' } \\ & \text { nya telat dah } \\ \text { he swallowed completely vpt } \\ \text { 'He swallowed it completely.' } \\ \text { habih: } \\ \text { bayal hutak habih lepas dah } \\ \text { paid debt completely freed vpt } \\ \text { 'He paid off the debt completely.' } \\ \text { (Here /habih/ is interpreted as an adverb.) } \\ \text { lepas: } \\ \text { buwac suc dah ter } \\ \text { did finished vpt spt } \\ \text { 'We finished it.' } \\ \text { kunya melaw giter sudah dah } \\ \text { they spoke like that finish vpt } \\ \text { 'They finished speaking like that.' } \\ \text { sudah: }\end{array}$

3.2.2.4.9 Prepositions: These may be divided into prepositional particles (ppt) and specific prepositions (prep). All of the prepositional particles may function as the only filler of the Relator slot in the prepositional phrase (Section 4.1.3). Some of them, as listed below, are locational prepositional particles which can be followed by one of the prepositions to give a more specific location. Some non-locational prepositional particles are:

$\begin{array}{llll}\text { bekaq } & \text { 'like' } & \text { sama } & \text { 'with' } \\ \text { jangan } & \text { 'with' } & \text { taqdëq } & \text { 'since' } \\ \text { naq } & \text { 'of' } & \text { tedaq } & \text { 'until' } \\ \text { rupa } & \text { 'like' } & \text { yu } & \text { 'until' }\end{array}$

The locational prepositional particles which may be followed by a preposition having a locational meaning are:

bëq 'location at' (with allomorphs /pëq/ and /päq/)

dëq 'location at' 


$\begin{array}{ll}\text { kaq } & \text { 'motion towards' } \\ \text { pac } & \text { 'location at' } \\ \text { soq } & \text { 'location at or besides' }\end{array}$

Prepositions which may occur alone or following one of the prepositional particles are represented by the following:

$\begin{array}{lll}\text { bawah } & \text { dëq bawah } & \text { 'below' } \\ \text { bidik } & \text { dëq bidik } & \text { 'besides, near' } \\ \text { blakak } & \text { dëq belakak } & \text { 'behind; later' } \\ \text { helot } & \text { soq helot } & \text { 'in front; before' } \\ \text { atas } & \text { soq atas } & \text { 'above, on top of }\end{array}$

The choice of which locational preposition to use seems to be idiosyncratic. Occasionally a speaker will use a Malay word such as <kepada > 'to' or <pada> 'at'. Examples of the usage of these prepositions will be found in Section 4.1.3 on Prepositional Phrases.

3.2.2.4.10 Conjunctions (cpt): These are divided into four categories: (a) coordinating conjunctions (cc), which link two coordinate clauses together; (b) subordinating conjunctions (cs) which link a subordinate clause to a main clause, with the subordinate clause appearing either before or after the main clause; (c) final subordinating conjunctions (csf), where the subordinate clause must follow the main clause; and (d) the relative pronoun /nu/ (rpn) described in Section 3.2.2.4.1 above. As explained there this pronoun operates as a word to fill the subject slot of the relative clause, but as a conjunction it links a subordinate embedded clause with the noun to which it relates.

Some typical conjunctions are as follows:

Coordinating conjunctions (cc):

Logical sequence:

$\begin{array}{llll}\text { jadi (caq) } & \text { 'therefore' } & \text { giter } & \text { 'so' } \\ \text { kaqgini } & \text { 'so' } & \text { kaqgiter } & \text { 'so' }\end{array}$

Adversative:

bukat 'but not' tapi 'but'

Temporal sequence:

$\begin{array}{llll}\text { baru } & \text { 'then' lalu } & \text { 'later' } \\ \text { semën } & \text { 'at the same time' } & \\ \text { kaqgiter bini } & \text { singi ada dalap rumah } & \\ \text { so } & \text { wife just-mentioned was in (the) house }\end{array}$

'So his wife was in the house.'

payah juga ter, bukat nu muda ter difficult also spt, not that which (is) easy spt 'It is quite difficult, not easy at all.' 
Baru belëh makat, baru belëh senang

then can eat, then get comfortable

'Then they can eat and be comfortable.'

\section{Subordinating conjunctions (cs):}

Cause:

$\begin{array}{llll}\text { krema } & \text { 'because' } & \text { krana } & \text { 'because' } \\ \text { sabëq } & \text { 'because' }\end{array}$

Conditional:

$\begin{array}{llll}\text { adu } & \text { 'if' } & \text { bekaq (caq) } & \text { 'as if' } \\ \text { kalaw } & \text { 'if (MLW) } & \text { kaq } & \text { 'if' } \\ \text { misël (caq) } & \text { 'even though' } & & \end{array}$

Temporal:

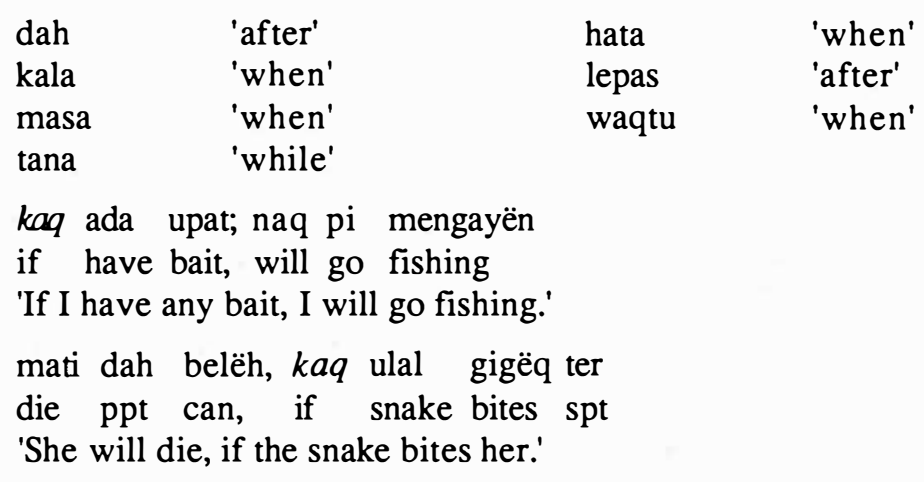

Final subordinating conjunctions (csf):

$\begin{array}{llll}\text { bri } & \text { 'so that' caq } & \text { 'that } \ldots \text { '.. } \\ \text { yu } & \text { 'until' } & \end{array}$

sakëq dëq proc ni, $y u$ ados-adoy ler sick in the stomach like-this, until crying-out-in-pain ept 'She had this pain in the stomach so that she was crying out in pain.'

Relative pronoun (rpn):

nu 'who, which, what'

jangan turoc kawat $n u$ berduwah

don't follow friend who lucky

'Don't follow the example of your lucky friend (your luck may be different).' 
3.2.2.4.11 Interrogative particle (qpt): There is only one particle in this class, the interrogative/ger/, which occurs at the end of a yes/no question.

$\begin{array}{ll}\text { belëh pi kaq lawoc ger? } & \text { belëh juga } \\ \text { can go to sea qpt } & \text { can also } \\ \text { 'Can you go to sea?' } & \text { 'Yes, I can.' } \\ \text { tunoq ku ger tët? } & \text { timaw tunoq } \\ \text { bow-to me or not? } & \text { don't -want bow } \\ \text { 'Will you bow down to me or not?' } & \text { 'We won't bow down.' }\end{array}$

3.2.2.4.12 Exclamations (exc): This is a small class of words which may occur, expressing emotion, giving a rhetorical pause in the sentence, or indicating the speaker has amended what he was going to say, or cannot think of the right word. There are various brief words which occur, which reflect the idiosyncracies of the particular speaker. The amount of text recorded does not permit a detailed analysis of their usage, but the fact that they can occur alone, and of ten bear a sentence intonation pattem, dictates that they should be regarded as words.

The following 25 exclamations appear in the computer concordance. It will be seen that phonologically they are mostly vowels or vowel clusters, many of them preceded by the glottal fricative $/ \mathrm{h} /$, together with the nasals $/ \mathrm{mm} /$ and $/ \mathrm{ngan} /$.

$\begin{array}{lllll}\text { a } & \text { ëq } & \text { hay } & \text { hoc } & \text { o } \\ \text { äq } & \text { er } & \text { he } & \text { hu } & \text { oc } \\ \text { am } & \text { ha } & \text { hë } & \text { mm } & \text { oh } \\ \text { aw } & \text { hä } & \text { her } & \text { ng } & \text { oy } \\ \text { ë } & \text { häq } & \text { ho } & \text { ngan } & \text { u }\end{array}$

The exclamations below are more specific ones with particular points of interest:

ados-adoy: This is an exclamation of pain or distress, which always commences with a single utterance of /ados/ followed by a continual repetition of /adoy/. When prefixed by /ber-/ it becomes the verb/berados/, meaning to be uttering this cry of pain.

anu: $\quad=$ 'What is it?', an expression used as the speaker gropes for the word he wants. If he knows the listener knows what he means, the word /anu/ may be inserted in place of the missing word, with no attempt for the right word.

bisemilah: This is a Muslim expletive, meaning 'in the name of Allah'. It is not in general use among the UL.

lah: $\quad$ This is a Muslim expletive, being an abbreviation of the name of $<$ Allah> 'God'. It is in common use among the UL.

loh: A common expletive, possibly a variant of $/$ ah/.

nama: The UL word for 'what', sometimes used as an exclamation while the speaker tries to think of the right word. 
tahu: $\quad$ The word /tahu/ 'know' is used idiomatically with the negative meaning 'I don't know'. The same idiom occurs in colloquial Malay.

nya maräh pëq diha? tahu he come place where?' 'Know!'

'Where does he come from?' 'I don't know.'

toq: $\quad$ This is a Buddhist expletive, being derived from the Thai word for Buddha.

\subsubsection{Application of these word classes}

The application of these word classes is illustrated by some typical dictionary entries, and by a sample of text. Each dictionary entry is labelled to indicate the word class in differing syntactic contexts. This is illustrated with /bri/ 'to give', a word which functions in various word classes, and with the word /lepas/ 'to be free', a word which undergoes affixation. Typical entries are given, but without normal dictionary abbreviations, and with examples of each usage.

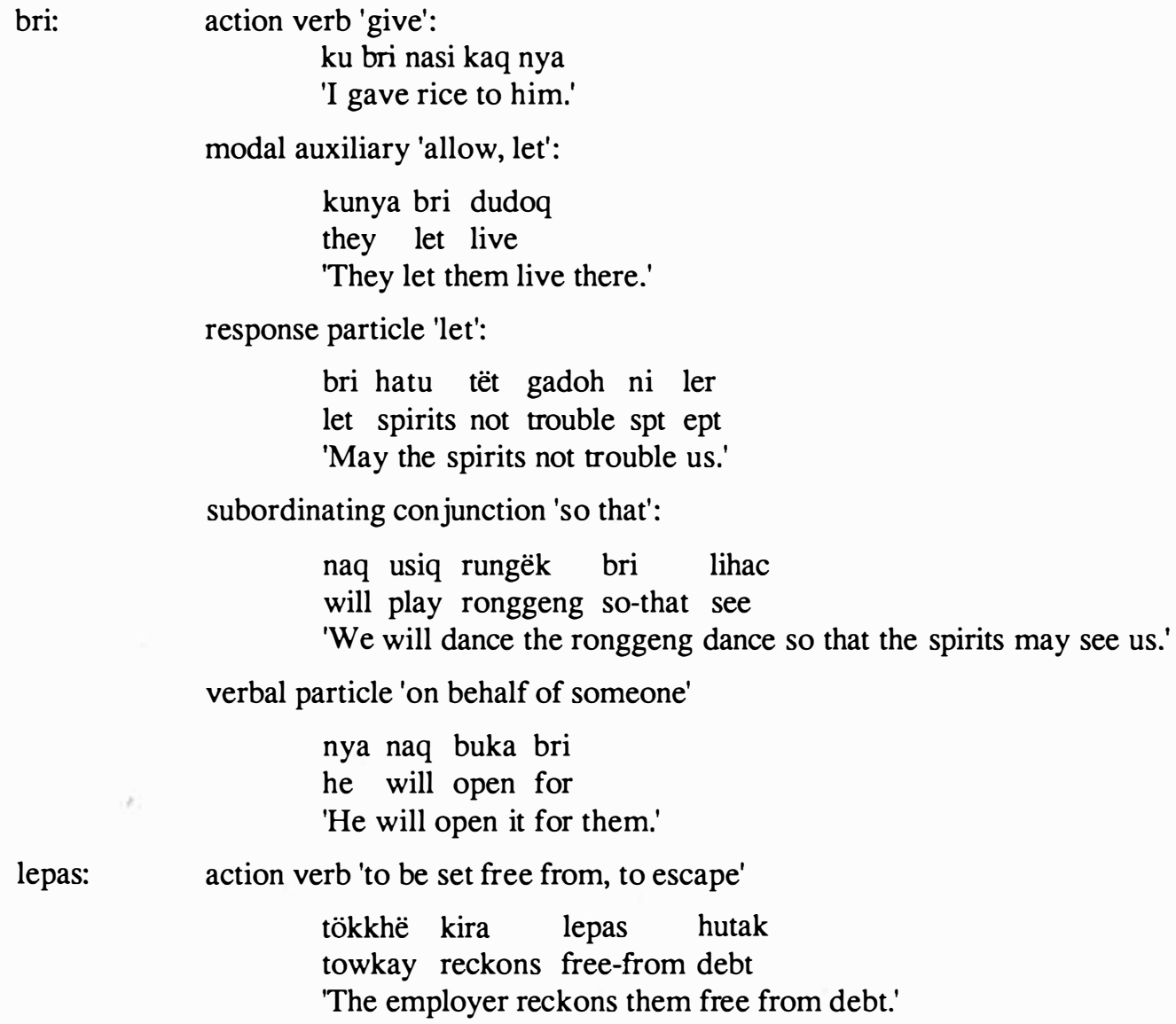




prepositional particle 'after'
lepas itu, pi berjalat lalu dah
after that, go walking past vpt
'After that we travelled on (to Bangkok).'
plepas: $\quad$ action verb 'set free'
nya baru plepas dëq ratay dah
he newly set free from chains vpt
'He is just out of jail.'
melepas: $\quad$ action verb 'to be delivered, be born'
nanaq kilaki melepas dah
child boy delivered vpt
'A baby boy has been born.'

A brief sample of text is analysed in terms of the word classes which occur in it:

koq nanaq semay ini, kunya menyegat pi rongrian. kaqgiter, ët dëq nya the children age this, they are-lazy go school. so, mother of them gatöq gatöq, "Segat naq pi, suka naq budö." dëq blakak ter, baru pi belajal. beat beat, "Lazy to go, likes to be-stupid." At later spt, then go study. belajal belëh panay dah, belëh terbëq, bri senang-hati. tët belëh terbëq, Study can be-wise vpt, can go-out, so-that heart-at-rest. Not can go-out, senang bëq diha? rest place where?

Free translation: 'The children of this age are lazy to go to school. So their mother must beat them and beat them, saying, "You are lazy to go to school. You like to be stupid." After that they go to study. When they have studied and got wisdom, then they can graduate with a heart at rest. If they can't graduate, where will they find rest?'

An indication of the classes of the various words is given, in the order in which they first appear:

$\begin{array}{lll}\text { koq } & \text { initial determiner particle } & \text { 'the' } \\ \text { nanaq } & \text { common noun, human } & \text { 'children' } \\ \text { semay } & \text { common noun, inanimate (TLW) } & \text { 'period, age' } \\ \text { ini } & \text { determiner particle } & \text { 'this' } \\ \text { kunya } & \text { personal pronoun } & \text { 'they' } \\ \text { menyegat } & \text { adjectival verb + prefix } & \text { 'are lazy' } \\ \text { pi } & \text { action verb } & \text { 'go' } \\ \text { rongrian } & \text { common noun, inanimate (TLW) } & \text { 'school' } \\ \text { kaqgiter } & \text { coordinate conjunction } & \text { 'so' } \\ \text { ët } & \text { common noun, human } & \text { 'mother' } \\ \text { dëq } & \text { prepositional particle } & \text { 'of, at' } \\ \text { nya } & \text { personal pronoun } & \text { 'he, she, it' }\end{array}$




$\begin{array}{lll}\text { gatöq } & \text { action verb } & \text { 'hit, beat' } \\ \text { segat } & \text { adjectival verb as auxiliary verb } & \text { 'lazy' } \\ \text { naq } & \text { auxiliary particle } & \text { 'will' } \\ \text { suka } & \text { action verb as auxiliary verb } & \text { 'like' } \\ \text { budö } & \text { adjectival verb } & \text { 'to be stupid' } \\ \text { blakak } & \text { common noun, inanimate } & \text { 'back' } \\ \text { ter } & \text { syntactic particle } & \text { (Phrase final) } \\ \text { baru } & \text { coordinate conjunction } & \text { 'then' } \\ \text { belajal } & \text { action verb } & \text { 'study' } \\ \text { belëh } & \text { action verb as auxiliary verb } & \text { 'can' } \\ \text { panay } & \text { adjectival verb } & \text { 'to be wise' } \\ \text { dah } & \text { verbal particle } & \text { past tense } \\ \text { terbëq } & \text { action verb } & \text { 'to go out' } \\ \text { bri } & \text { final subordinating conjunction } & \text { 'so that' } \\ \text { senang-hati } & \text { adjectival verb } & \text { 'heart at rest' } \\ \text { tët } & \text { negative response } & \text { 'not' } \\ \text { senang } & \text { adjectival verb } & \text { 'to be at rest' } \\ \text { bëq } & \text { common noun, inanimate } & \text { 'place' } \\ \text { diha } & \text { interrogative adverb } & \text { 'where?' }\end{array}$




\section{CHAPTER 4}

\section{PHRASE LEVEL}

Phrase Level is the level which is below Clause Level and above Word Level. A phrase is made up of a group of words which operate as a unit to fill various functional slots at Clause Level. Phrases do not have the essential characteristic of a clause which enables a clause to make a predication about a subject. Noun and prepositional phrases do not have any predicate element. The verb phrase does operate as the predicate of a clause, but when it is considered at Phrase Level, it is analysed in terms of its constituent parts. A phrase has the potential of two or more words, but except for prepositional phrases, its minimal form may consist of only the head word of the phrase, but always with the potential for expansion.

The phrases of Urak Lawoi' will first be considered in terms of their structure, and then in terms of their function in the grammar.

\subsection{Types of phrase structure}

The three types of phrases in Urak Lawoi' are the Noun Phrase (NP), the Verb Phrase (VP), and the Prepositional Phrase (PP). There is also the Coda (Co), which is not a phrase so much as a cluster of particles which occur together clause-finally.

\subsubsection{Noun phrase}

\subsubsection{Types of noun phrase}

In studying the corpus of UL text it was possible to identify many noun phrases by the presence of the final marker Mf:. Phrases of type NPb were identified by the obligatory presence of the initial marker Mi:, with its fillers, the initial determiner particles /koq/ 'the' and /koq lumöh/ 'the many'. In this way 121 instances of NPb were found in the corpus. All other noun phrases which did not have the initial marker were classified as type NPa. 1215 instances of these phrases were identified by the presence of the final marker Mf:. Many other noun phrases could not be readily identified, because they did not have the final marker. The structure of the two main phrase types is set out in Table 4-1. 
Table 4-1. Structure of the noun phrase

\begin{tabular}{|c|c|c|c|c|c|c|c|}
\hline $\begin{array}{l}\text { Phrase } \\
\text { Type }\end{array}$ & \multicolumn{2}{|c|}{ Pre-nuclear } & $\begin{array}{c}\text { Nucleus } \\
\text { H: }\end{array}$ & \multicolumn{4}{|c|}{ Post-nuclear Periphery } \\
\hline $\mathrm{NPa}$ & - & $\begin{array}{c} \pm \\
\text { num } \\
\text { ipn }\end{array}$ & $\begin{array}{l}+ \\
\mathrm{nn} \\
\mathrm{pn} \\
\mathrm{cl} \\
\text { Clnu }\end{array}$ & $\begin{array}{l} \pm \\
\text { vaj } \\
\text { vac } \\
\text { PP } \\
\mathrm{NP} \\
\text { Clnu }\end{array}$ & $\begin{array}{l} \pm \\
\text { nn } \\
\text { ppn } \\
\text { PP }\end{array}$ & $\begin{array}{l} \pm \\
\text { num } \\
\text { ipn }\end{array}$ & $\begin{array}{l} \pm \\
( \pm \mathrm{dpt} \pm \mathrm{spt} \pm \mathrm{ept})\end{array}$ \\
\hline $\mathrm{NPb}$ & & - & $\begin{array}{l}+ \\
\mathrm{nn} \\
\mathrm{pn}\end{array}$ & $\begin{array}{l} \pm \\
\text { vaj } \\
\text { vac } \\
\text { PP } \\
\text { NP } \\
\text { Clnu }\end{array}$ & $\begin{array}{l} \pm \\
\text { nn } \\
\text { ppn } \\
\text { PP }\end{array}$ & - & $\begin{array}{l} \pm \\
( \pm d p t \pm s p t \pm \text { ept })\end{array}$ \\
\hline
\end{tabular}

The following symbols ending with : represent structural slots at phrase level:

$\begin{array}{llll}\text { H: } & \text { Head word } & \text { Mi: } & \text { Initial Marker } \\ \text { Mf: } & \text { Final Marker } & \text { Mod: } & \text { Modifier } \\ \text { Pos: } & \text { Possessor } & \text { Qn1: } & \text { Pre-head Quantifier } \\ \text { Qn2: } & \text { Post-head Quantifier } & & \end{array}$

The symbols listed below this show the various fillers which may function in the slot. PP is a Prepositional Phrase and NP is a Noun Phrase, both layering to act as a filler at phrase level. Clnu is a relative clause which is here embedded in a slot at phrase level. The other symbols in lower case represent words operating as phrase level fillers in the normal way:

$\mathrm{nn} \quad$ symbol for nouns collectively, including -

$\begin{array}{llll}\text { nab } & \text { abstract noun } & \text { ncl } & \text { noun cluster } \\ \text { nca } & \text { common noun, animate } & \text { nco } & \text { coordinated nouns } \\ \text { nch } & \text { common noun, human } & \text { npl } & \text { proper noun, locational } \\ \text { nci } & \text { common noun, inanimate } & \text { npp } & \text { proper noun, personal }\end{array}$

pn symbol for pronouns collectively, including -

dpn demonstrative pronoun ipn indefinite pronoun

qpn interrogative pronoun ppn personal pronoun

rpn relative pronoun

num numeral; i.e. simple or complex number, or a number plus a numerical classifier 
cl numerical classifier, including -

clm classifier, metrical

cln classifier, numerical

vaj verbal adjective vac action verb

neg negative

dpt final determiner particle

dpti initial determiner particle

spt syntactic particle

ept emphatic particle

The following restrictions apply to these two formulae:

1. In NPa, Qn1: and Qn2: are mutually exclusive.

2. In NPa, if vac fills the Mod: slot, there must be a filler in the Mf: slot.

3. In NPb, the only filler of the Mi: slot is the initial determiner particle / $/ \mathrm{kq} /$, or its variant koq lumöh/.

4. In $\mathrm{NPb}$, the determiner particles /ini/ 'this' or /itu/ 'that' do not normally appear in the final marker slot.

There are two fundamental differences between these two phrase types: (1) as stated above the initial marker is obligatory in $\mathrm{NPb}$, but never occurs in $\mathrm{NPa}$; (2) the structural slots of $\mathrm{NPb}$ have a more restricted range of occurrence and fillers than in $\mathrm{NPa}$, as shown in the formulae and the restrictions.

\subsubsection{NPa noun phrase}

This phrase has a nucleus where a noun or a noun substitute as listed in the table acts as the obligatory head of the phrase. There is the potential for one quantifier tagmeme before the nucleus, and for up to four tagmemes after it: the modifier, the possessor, the post-head quantifier and the final marker slots. It is rare to find more than one of these slots filled in any single phrase, and there are no instances of all of them being filled in one phrase.

The phrase will be described in terms of each tagmeme slot in turn, with the tagmemic structure of the phrase stated and the filler under focus highlighted.

4.1.1.2.1 Head slot (H:). In its simplest form NPa may consist of the head slot only, filled by a noun, a noun cluster, coordinated nouns, a pronoun, a classifier or a relative clause.

$$
\begin{gathered}
\mathrm{NPa}=\mathrm{H}: \mathrm{nn} \\
\text { brutat } \\
\text { 'tiger' } \\
\mathrm{NPa}=\mathrm{H}: n c o \\
\text { laki bini } \\
\text { 'husband wife' }
\end{gathered}
$$

$$
\begin{aligned}
& \mathrm{NPa}=\mathrm{H}: \text { ncl } \\
& \text { kapan matang } \\
& \text { 'ship Matang' } \\
& \mathrm{NPa}=\mathrm{H}: \mathrm{pn}+\mathrm{Mf}: \text { ept } \\
& \text { nya ler } \\
& \text { 'he ept' }
\end{aligned}
$$




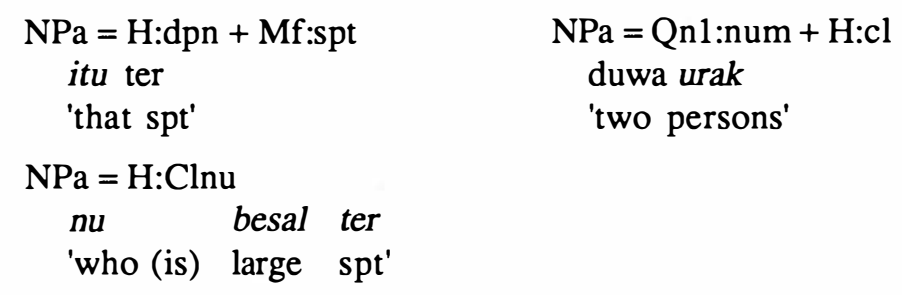

4.1.1.2.2 Pre-head quantifier slot (Qn1:). This is an optional slot which may be filled by a numeral or an indefinite pronoun.

$$
\begin{array}{cc}
\mathrm{NPa}=\mathrm{Qnl}: \mathrm{ipn}+\mathrm{H}: \mathrm{cl} & \mathrm{NPa}=\mathrm{Qnl}: \mathrm{ipn}+\mathrm{H}: \mathrm{nn} \\
\text { tujoh urak } & \text { banyaq lagu } \\
\text { 'seven men' } & \text { 'many matters' }
\end{array}
$$

4.1.1.2.3 Modifier slot (Mod:). This is an optional post-nuclear slot which may be filled by a verbal adjective, an action verb acting as an adjective, a prepositional phrase, a noun phrase or a relative clause.

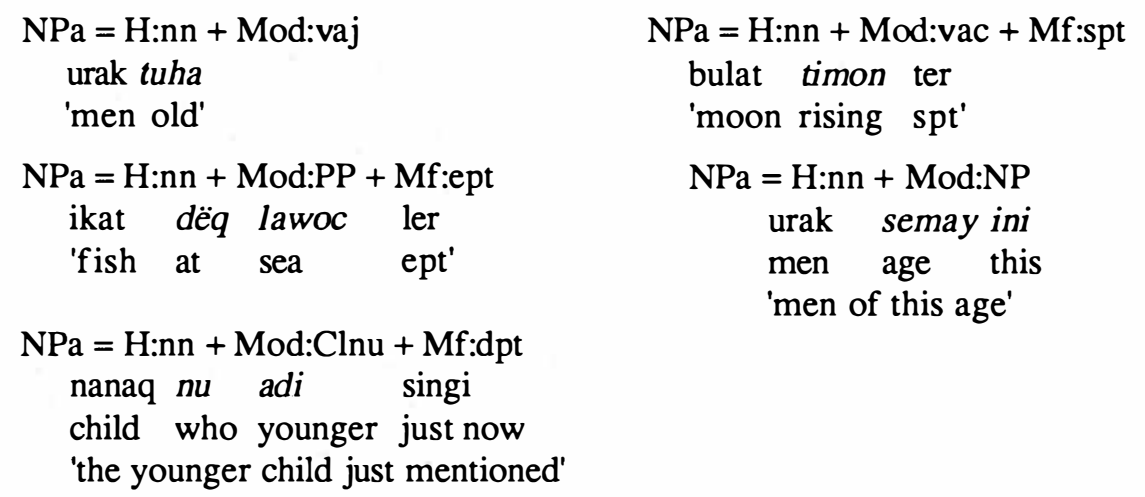

4.1.1.2.4 Possessor slot (Pos:). This is the second optional slot after the nucleus. It may be filled by a noun, a pronoun, or a prepositional phrase.

$\begin{array}{cc}\mathrm{NPa}=\mathrm{H}: \mathrm{nn}+\text { Pos:nn } & \mathrm{NPa}=\mathrm{H}: \mathrm{nn}+\text { Pos:pn } \\ \text { prahu semiya } & \text { rumah kita } \\ \text { 'boat (of) man' } & \text { 'house ours' } \\ \mathrm{NPa}=\mathrm{H}: \mathrm{nn}+\text { Pos:PP } & \mathrm{NPa}=\mathrm{H}: \mathrm{nn}+\text { Pos:PP } \\ \text { bini naq } \mathrm{ku} & \text { maq dëq } \mathrm{ku} \\ \text { 'wife of mine' } & \text { 'mother of mine' }\end{array}$

(Note the different preposition used for a blood relation.) 
4.1.1.2.5 Post-head quantifier slot (Qn2:). This is the third optional slot after the nucleus. It may be filled by a numeral or an indefinite pronoun.

$$
\begin{array}{ccc}
\mathrm{NPa}=\mathrm{H}: \mathrm{nn}+\mathrm{Qn2}: \mathrm{num} & \mathrm{NPa}=\mathrm{H}: \mathrm{nn}+\mathrm{Qn2} 2 \mathrm{ipn} \\
\text { nanaq duwa urak } & \text { minyaq banyaq } \\
\text { 'children two persons' } & \text { 'oil much' }
\end{array}
$$

4.1.1.2.6 Final marker slot (Mf:). This is the final optional post-nuclear slot. It may be filled jointly by up to three particles: a final determiner particle (dpt), a syntactic particle (spt), and an emphatic particle (ept). If there is more than one particle, they normally occur in the same order as they have been mentioned above.

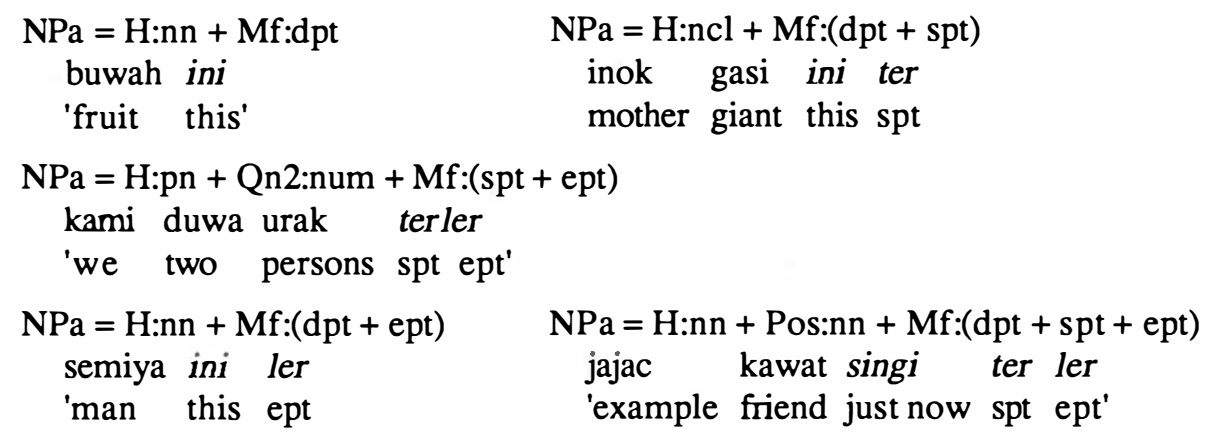

\subsubsection{NPb noun phrase}

This phrase has an obligatory head slot, filled by a noun or noun substitute. This is preceded by an obligatory initial marker tagmeme, and followed by up to three optional post-nuclear tagmemes, the modifier, possessor and final marker slots. There are no quantifier slots, but the initial determiner particle which may fill the initial marker slot frequently signifies a plural subject (Section 3.2.2.4.7). The head, modifier and possessor slots are similar to the equivalent slots in $\mathrm{NPa}$, so they will not be described again. Normally there is a filler in only one of the modifier and possessor slots. Final marker slot in NPb differs from that in NPa in that the determiner particles /ini/ 'this' and /itu/ 'that' do not normally appear in it.

4.1.1.3.1 Initial marker slot (Mi:). This is filled by the initial determiner particle, which has the forms: /koq/ 'the' and /koq lumöh/ 'the many'.

$$
\begin{aligned}
& \mathrm{NPb}=\mathrm{Mi}: \mathrm{dpti}+\mathrm{H}: \mathrm{nn} \\
& \text { koq ijën } \\
& \text { 'the engine' }
\end{aligned}
$$

$$
\begin{aligned}
& \mathrm{NPb}=\mathrm{Mi}: \mathrm{dpt}+\mathrm{H}: \mathrm{pn}+\mathrm{Mf}: \mathrm{dpt} \\
& \text { koq lumöh kami ni } \\
& \text { the group we this } \\
& \text { 'this group of us' }
\end{aligned}
$$




\subsubsection{Verb phrase}

\subsubsection{Types of verb phrase}

The three types of verb phrase, comprising the Action Verb Phrase (VPac), the Stative Verb Phrase (VPst), and the Equative Verb Phrase (VPeq), are set out in Table 4-2.

Table 4-2. Structure of the verb phrase

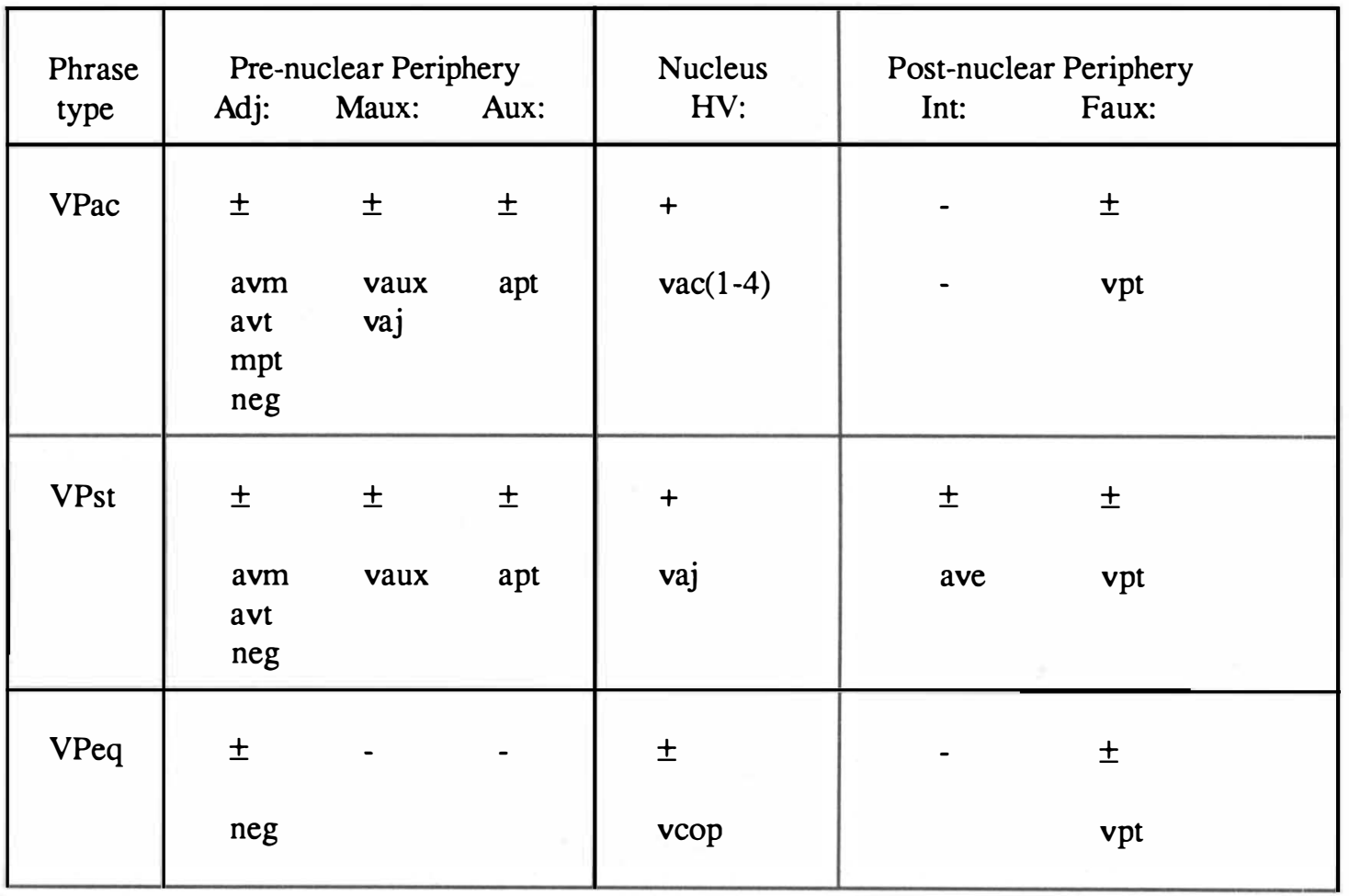

The following symbols ending with : represent structural slots at phrase level:
Adj: $\quad$ Adjunct
Aux: Auxiliary
Faux: Final Auxiliary
HV: $\quad$ Head Verb
Int: Intensifier
Maux: Modal Auxiliary

The symbols listed below show the various fillers which may function in the slots:

$\begin{array}{ll}\text { vac(1-4) } & \text { action verb with one to four elements } \\ \text { vaj } & \text { adjectival verb } \\ \text { vaux } & \text { auxiliary verb } \\ \text { vcop } & \text { copula verb } \\ \text { vpt } & \text { verbal particle } \\ \text { apt } & \text { auxiliary particle } \\ \mathrm{mpt} & \text { modal particle }\end{array}$




$\begin{array}{ll}\text { ave } & \text { adverb of extent } \\ \text { avm } & \text { adverb of manner } \\ \text { avt } & \text { adverb of time } \\ \text { neg } & \text { negative }\end{array}$

The following restrictions apply to these three formulae:

1. In VPac, the apt in the Aux: slot are the five auxiliary particles described in Section 3.2.2.4.8: /naq/ futurity or intention; /phakhac/ and/khac/ collectively; /tengah/ continuous action and /ada/ a continuing state. In VPst, /tengah/ does not occur.

2. In VPeq, the only vcop in the HV: slot is the verb /jadi/ 'to be, become', and its inflected form /mejadi/.

3. In VPac, the vpt in the Faux: slot are the seven verbal particles described in Section 3.2.2.4.8: /bri/ benefactive action, /buwak (dah)/ final action, /dah/ past or decisive action, /habih (dah)/ completed action, /lepas (dah)/ freeing action, /suc (dah)/ finished action, /sudah (dah)/ finished action. In VPst and VPeq, vpt is restricted to /dah/only.

There are the following contrasts between these three types of verb phrase:

1. The head verb of VPac may be one to four action verbs, while the head verb of VPst and VPeq may only be one vaj or vcop respectively.

2. VPac has an optional Adjunct slot initially in its pre-nuclear periphery with fillers avm, avt, mpt, and neg, while VPst has the fillers avm, avt and neg and VPeq has only the filler neg in this slot.

3. The Auxiliary slot in VPac has five potential fillers, but VPst has only four fillers for this slot, and VPeq has none.

4. The Final Auxiliary slot in VPac has seven potential fillers, but that in VPst and VPeq has only one filler.

5. VPst has the optional Intensifier slot filled by an adverb of extent, which does not occur in VPac or VPeq.

6. VPeq contrasts with the other two verb phrases in that its nuclear Head Verb is optional, and its only peripheral elements are the optional Adj: slot with filler neg, and the optional Faux: slot with the single filler /dah/.

7. The Modal Auxiliary slot in VPac may have either vaux or vaj as fillers, while in VPst it may only have vaux. It does not occur in VPeq.

These three types of verb phrase will be discussed in detail in the following sections. Then the verb of saying and perceiving (vsp) will be outlined in Section 4.1.2.5. 


\subsubsection{Action verb phrase}

This phrase has a nucleus of up to four action verbs acting as the obligatory Head Verb. There are three optional tagmemes before the nucleus and one optional tagmeme after it. It will be described in terms of each tagmemic slot in tum. The phrases given as examples will be given in the context of whole sentences, with the verb phrase italicised and the tagmemic structure of the verb phrase stated.

4.1.2.2.1 Head verb slot. In its simplest form the VPac may consist of a Head Verb slot with a single action verb (vac) as described in Section 3.2.2.2 as the filler:

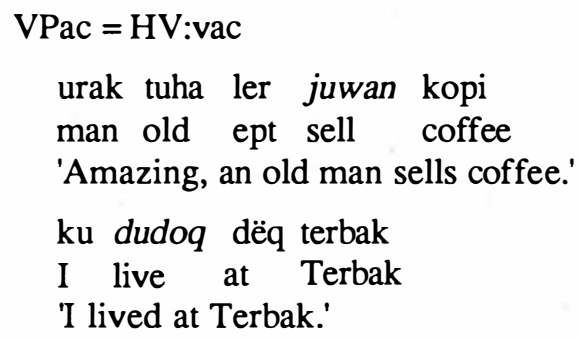

There can be a cluster of two, three or four action verbs functioning in one HV: slot, all speaking of the one action, or different aspects of that action. The number in brackets in the formula shows how many action verbs there are in the cluster.

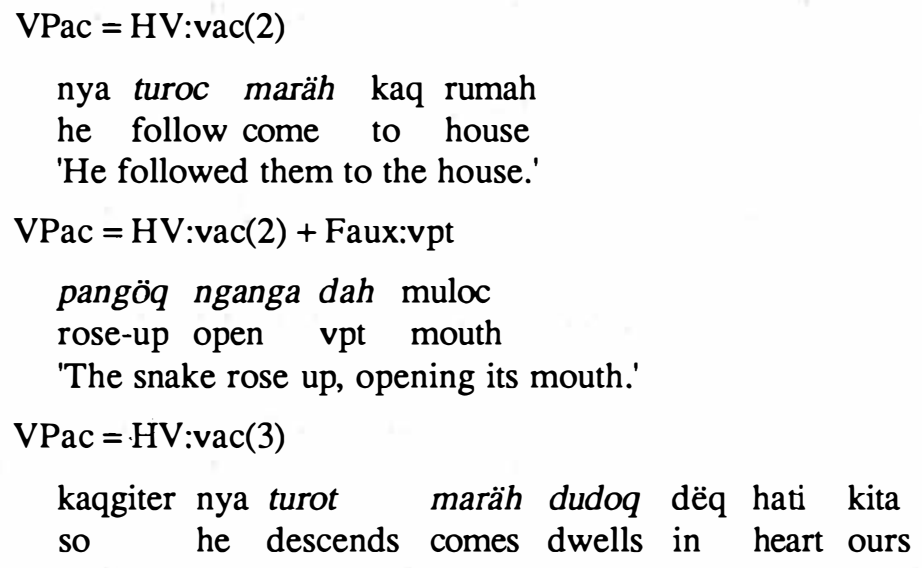

'So he comes down to dwell in our heart.'

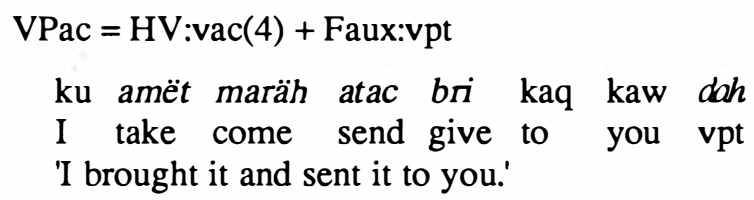

These clusters of verbs act as one unit, describing the same action and sharing the same subject. So in the first example above/turoc/ and /maräh/ share the same subject, but/turoc/is a transitive verb 'follow' with the object /kunya/ 'them' deleted, while /maräh/ 'come' is an intransitive verb followed by the location adjunct/kaq rumah/ 'to the house'. In this way the action is broken down 
into its component parts, listed in chronological order. Where, in the last example, English would say 'I sent it to you', UL says 'I take-come-send-give it to you'.

In my earlier article on UL syntax (1978:22), I gave a tentative formula for this verb cluster as -

\pm Pre-verb + Head Verb \pm Post-verb

This was patterned on the analysis of the Thai verbal phrase by Noss (1964:133ff), and Vichin (1970:83ff, 129). This analysis proved to be difficult to apply to UL. It is simpler to define the filler of the slot as a cluster of verbs, together describing the action concerned.

Sometimes the cluster of verbs is divided by the insertion of other words, but the different verbs still operate as a single cluster with a common subject.

$$
\begin{aligned}
& \mathrm{VPac}=\mathrm{HV}: \operatorname{vac}(1-1) \\
& \text { kunya amët ler buwah berbaliq } \\
& \text { they take ept fruit returning } \\
& \text { 'They actually took the fruit and returned it.' }
\end{aligned}
$$

Here the verb phrase is separated by two items: the emphatic particle /ler/, emphasizing their taking the fruit, and then the object, the fruit they had taken. Yet it is still all one action, but divided into two parts, as signalled by the $(1-1)$ in the apparatus.

Where an object appears early in the apparent cluster of verbs, and is followed by a phonological clause break, then that cluster must be interpreted as two separate HV: in different clauses.

$$
\begin{aligned}
& \text { VPac = Hv:vac; VPac }=\text { Hv:vac(2) } \\
& \text { nya amët guni; pi tudok soq lubak nu sa } \\
& \text { he get sack; goes closes side hole which one } \\
& \text { 'He got the sack and put it over one side of the hole.' }
\end{aligned}
$$

In another clause, a sequence of five verbs has been interpreted as four clauses. It occurs in a description of a team of UL divers salvaging iron from sunken vessels.

$$
\begin{gathered}
\mathrm{VPac}=\mathrm{HV}: \operatorname{vac}(1-1) ; \mathrm{VPac}=\mathrm{Hv}: \mathrm{vac} ; \mathrm{VPac}=\mathrm{Hv}: \mathrm{vac} ; \mathrm{VPac}=\mathrm{HV}: \mathrm{vac} \\
\text { amët tangcaw pi; tuwin; bemyanyëq; galak } \quad \text { ter } \\
\text { get crowbar go; lever; raise; }
\end{gathered}
$$

'They take the crowbar; lever the iron; raise it to the surface; place it on the thwarts of the boat.'

These four clauses are linked by a common Subject, but there are two Objects. In the first clause the Object is the crowbar which they take. In the second clause they use this crowbar to lever the iron. Then they raise the iron to the surface, and finally lay it on the thwarts of their boat. These four verbs speak of four distinct actions, spread over a period of time, so must be interpreted as being in separate clauses. This is supported by the phonological pattern of the sentence which shows a clause break (;) between the various segments. 
In a similar construction, there is repetition of one of the vac fillers of the HV: slot to show emphasis, dramatic effect, or repetitive action.

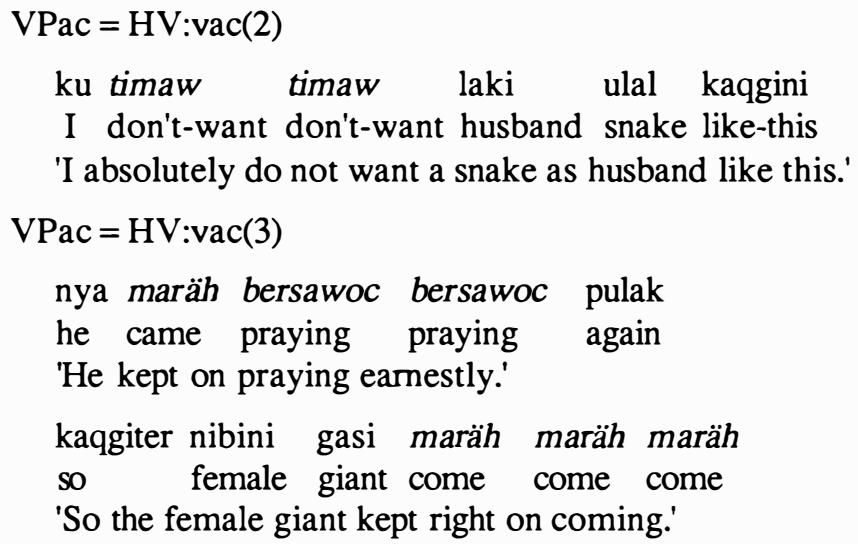

4.1 2.2.2 Adjunct slot. The Adj: slot occurs optionally as the first slot in the pre-nuclear periphery of the action verb phrase. It may be filled by an adverb of time or manner (Section 3.2.2.3), by a modal particle (Section 3.2.2.4.8) showing the speaker's attitude to the action described, or by a negative /hoy/ or /hoy tët/, both meaning 'not'. It occurs similarly in the Stative Verb Phrase with an adverb of time or manner or a negative and in the Equative Verb Phrase with its only filler being the negative.

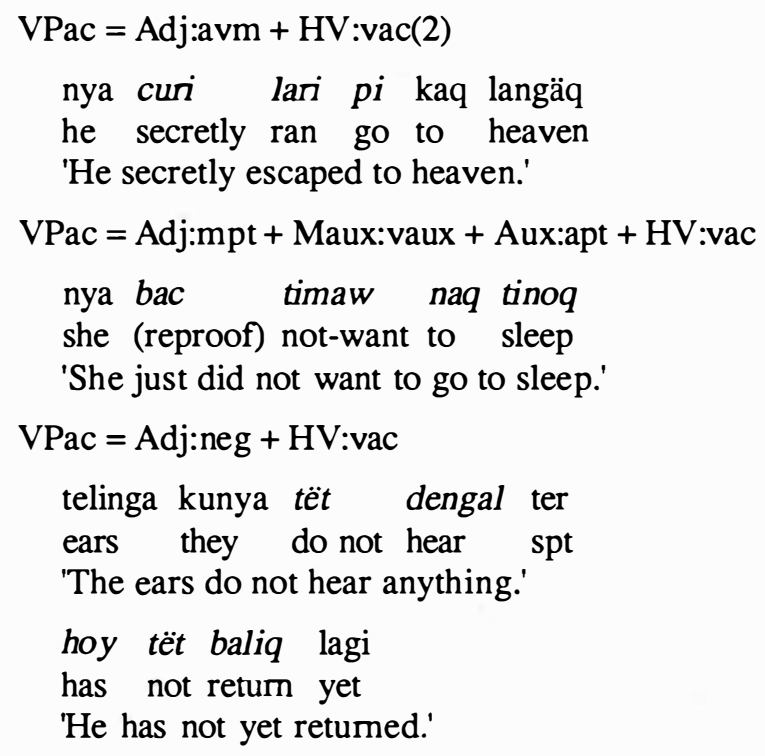


4.1.2.2.3 Modal auxiliary slot. The Maux: slot occurs optionally as the second slot in the pre-nuclear periphery of the Action Verb Phrase, or the Stative Verb Phrase. It may be filled with a verbal auxiliary (vaux) in both these phrases or by a verbal adjective (vaj) in the Action Verb Phrase.

$$
\begin{aligned}
& \text { VPac = Maux:vaux + HV:vac } \\
& \text { baru kita belëh makat sama } \\
& \text { 'Then we can eat together.' } \\
& \text { VPac = Maux:vaux + HV:vac(2) } \\
& \text { kita kena pi mengayën } \\
& \text { 'We must go fishing.' } \\
& \text { VPac = Maux:vaux + Aux:apt + HV:vac } \\
& \text { kita kena naq dudoq senang } \\
& \text { we must will dwell at-ease } \\
& \text { 'We will certainly dwell at ease.' } \\
& \text { VPac = Maux:vaj + Aux:apt + Hv:vac } \\
& \text { nya segat naq pi rongrian } \\
& \text { he lazy to go school } \\
& \text { 'He does not want to go to school.' }
\end{aligned}
$$

4.1 2.2.4 Auxiliary slot. The Aux: slot is the third slot in the pre-nuclear periphery of the verb phrase, coming immediately before the nuclear head verb. It is optionally filled by one of the five auxiliary particles (apt) described in Section 3.2.2.4.8; i.e. /naq/ will, /phakhac/ and /khac/ collectively, /tengah/ continuous action, and /ada/ continuous state. Section 3.2.2.4 shows how these particles operate to identify the following word as a verb.

$$
\begin{aligned}
& \text { VPac = Aux:apt + HV:vac } \\
& \text { ku naq makat nasi } \\
& \text { 'I will eat rice.' } \\
& \text { VPac = Aux:apt + HV:vac(2) } \\
& \text { kami phakhac pi kerja besi } \\
& \text { we (excl) collectively go work iron } \\
& \text { 'We go together to work gathering scrap iron.' } \\
& \text { VPac = Aux:apt + HV:vac } \\
& \text { khac kelilik rumah cawsaw } \\
& \text { together go-round house bride } \\
& \text { 'They go together around the bride's house.' } \\
& \text { nya tengah tinoq ni } \\
& \text { 'He is sleeping now.' }
\end{aligned}
$$




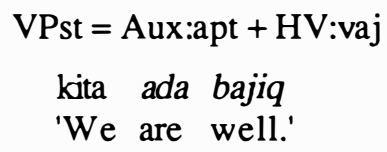

4.1.2.2.5 Final auxiliary slot. Faux: is the final slot in the verb phrase, and in VPac it is the only slot to occur in the post-nuclear periphery of that phrase. It is of ten separated from the rest of the verb phrase by the Object and Adjuncts, and is located as the first item in the clause-final Coda. Grammatically it functions as a discontinuous verb phrase, and it will be referred to again when describing the Coda (4.1.4).

There are seven fillers of this slot, as described in Section 2.2.2.4.8, and as listed below. Five of them may be optionally followed by the particle/dah/as shown.

$\begin{array}{ll}\text { bri } & \text { action on behalf of someone else } \\ \text { buwak (dah) } & \text { finality } \\ \text { dah } & \text { past action or decisive action } \\ \text { habih (dah) } & \text { completed action } \\ \text { lepas (dah) } & \text { freedom from an undesirable state } \\ \text { suc (dah) } & \text { finished action } \\ \text { sudah (dah) } & \text { finished action }\end{array}$

The words /habih/, /lepas/, /suc/ and /sudah/ can sometimes function as action verbs, or as adverbs, and /sudah/also functions as an auxiliary verb. This makes it difficult to decide how it is functioning in some clauses. The following examples show cases where it has been interpreted as Faux:

$$
\begin{aligned}
& \text { VPac = HV:vac + Faux:vpt } \\
& \text { nya buwac ler; buwac nasi bri } \\
& \text { he made ept; made rice on-their-behalf } \\
& \text { 'He did it; he cooked rice for them.' } \\
& \text { VPac = HV:vac(3) + Faux:vpt } \\
& \text { nya turot cäw pi kaq Tökkha buwak ler } \\
& \text { he descend row go to Phuket finally ept } \\
& \text { 'He got into his boat and rowed to Phuket.' } \\
& \text { VPac = HV:vac + Faux:vpt(2) } \\
& \text { semata nya pi buwak dah } \\
& \text { wholeheartedly he go decisively vpt } \\
& \text { 'He deliberately went (and will not return).' } \\
& \text { VPac = HV:vac + Faux:vpt } \\
& \text { nya amët bini dah } \\
& \text { he take wife vpt } \\
& \text { 'He took a wife.' }
\end{aligned}
$$




$$
\begin{aligned}
& \text { VPac = HV:vac + Faux:vpt(2) } \\
& \text { nya dehani habih dah } \\
& \text { he aroused completely vpt } \\
& \text { 'He woke right up.' } \\
& \text { VPac = HV:vac + Faux:vpt(2) } \\
& \text { nya bayal hutak habih } \\
& \text { he paid debt completely freed vpt } \\
& \text { 'He paid off the debt completely.' } \\
& \text { (Here /habih/ is interpreted as an adverb.) } \\
& \text { VPac = HV:vac + Faux:vpt(2) } \\
& \text { kita buwac rumah suc } \\
& \text { we made house finished vpt } \\
& \text { 'We finished building the house.' } \\
& \text { VPac = HV:vac + Faux:vpt(2) } \\
& \text { kunya melaw giter sudah dah } \\
& \text { they spoke like-that finished vpt } \\
& \text { 'They finished speaking like that.' }
\end{aligned}
$$

\subsubsection{Stative verb phrase}

The Stative Verb Phrase (VPst) has an adjectival verb as the obligatory head verb, preceded by three optional slots, Adj:, Maux:, and Aux:, and followed by two optional slots, Int: and Faux:.

4.1.2.3.1 Head slot. The adjectival verb (vaj) which fills the head slot of VPst is described in Section 3.2.2.2. It is a word which may function as a head verb in VPst, as a modal auxiliary in VPac (Section 4.1.2.2.3), or as an adjective in the modifier slot of the noun phrase (Section 4.1.1.2.3). There is never more than one vaj as filler of the HV: slot in this phrase. Its occurrence in the VPst head slot is as follows:

$$
\begin{aligned}
& \text { VPst }=\text { HV:vaj + Faux:vpt } \\
& \text { semiya itu sakëq dah } \\
& \text { man that sick vpt } \\
& \text { 'That man is sick.' }
\end{aligned}
$$

4.1.2.3.2 Adjunct slot. In VPst, the Adj: slot has only one filler, the negative neg. The only negatives that can occur in this slot are /hoy/ 'not' and /hoy tët/ 'not'.

$$
\begin{aligned}
& \text { VPst = Adj:neg + HV:vaj } \\
& \text { koq nanaq tët senang-nyawa ter } \\
& \text { the children are-not well } \\
& \text { 'The children are unwell.' }
\end{aligned}
$$




$$
\begin{aligned}
& \text { hoy tët senang pot } \\
& \text { is not well spt } \\
& \text { 'He is not well.' } \\
& \text { VPst = Adj:avm + Aux:apt + HV:vaj } \\
& \text { koq lumöh ini mudah naq sakëq-gigi ni } \\
& \text { the group this are-easy to be-sick-teeth spt } \\
& \text { 'This group are prone to suffer toothache.' }
\end{aligned}
$$

In this last example, the word for 'suffer toothache' is the compound word /sakëq-gigi/, where a verbal adjective and a noun combine to produce a verbal adjective (Section 3.1.4).

4.1.2.3.3 Modal auxiliary slot. The optional Maux: slot is filled by vaux as in the Action Verb Phrase, as described in Section 4.1.2.2.3.

$$
\begin{aligned}
& \text { VPst = Maux:vaux + HV:vaj + Faux:vpt } \\
& \text { belajal; belëh panay dah } \\
& \text { study; can be wise vpt } \\
& \text { 'If they study, they can get knowledge.' } \\
& \text { VPst = Maux:vaux + Aux.apt + HV:vaj } \\
& \text { suka naq budö } \\
& \text { like to be-stupid } \\
& \text { 'They prefer to be ignorant.' }
\end{aligned}
$$

4.1.2.3.4 Auxiliary slot. This is the third slot in the pre-nuclear periphery of VPst. The Aux: slot in VPst is filled by four of the auxiliary particles described in Section 3.2.2.4.8, but not by the particle/tengah/. There are illustrations in previous sub-sections of the occurrence of /naq/. The following examples show $/$ phakhac/, / khac/ and /ada/ as the fillers of this slot.

$$
\begin{aligned}
& \text { VPst = Aux:apt }+ \text { HV:vaj } \\
& \text { kami phakhac besal dëq tupoq Terbak ter ler } \\
& \text { we (excl) together are-big at village Terbak spt ept } \\
& \text { 'We grew up together in the village of Terbak.' } \\
& \text { khac suka-hati } \\
& \text { together are glad } \\
& \text { 'They are glad.' } \\
& \text { ada senang ter, nya senang } \\
& \text { is well spt; he is-well } \\
& \text { 'If his health is good, then he is well.' }
\end{aligned}
$$$$
\text { we (excl) together are-big at village Terbak spt ept }
$$ 
4.1.2.3.5 Intensifier slot. The Int: slot appears optionally directly after the HV: slot in VPst, and is filled by one of a small group of adverbs of extent (ave), modifying the HV:. Two of these ave, /banyaq/ 'much' and /dikiq/ 'a little', are normally indef inite pronouns, and the other two, /sungoh/ 'true' and /troq/'severe', of ten function as vaj. They only appear as modifying the vaj when it is functioning as a verb: they do not modify vaj when it is in an adjectival position, as in the English sentence, 'The very sick man went to hospital.'.

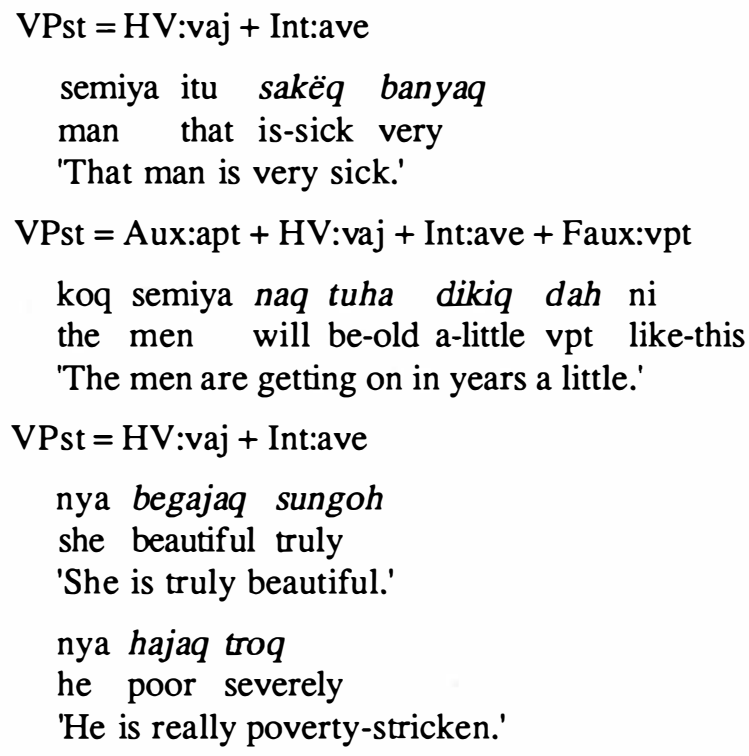

4.1.2.3.6 Final auxiliary slot. This is the final slot in the VPst phrase, and it is as described for the VPac in Section 4.1.2.2.5, except that it only has one filler/dah/, indicating past time or a definite state. An example of its occurrence can be seen in the second example in the previous sub-section.

\subsubsection{Equative verb phrase}

VPeq is an optional slot in the Equative Clause, with only one copula verb (vcop) acting as filler, the verb/jadi/ 'to be, to become', and its inflected form/mejadi/. The only peripheral slots to occur in this phrase are the optional Adj: slot, filled only by neg, or the optional Faux, with its only filler being the vpt /dah/ 'past time'.

$$
\begin{aligned}
& \text { VPeq = HV:vcop } \\
& \text { nya jadi bercac } \\
& \text { 'She became a bedbug.' } \\
& \text { VPeq = Adj:neg + HV:vcop (inverted) } \\
& \text { buwah nya hoy tët jadi ler } \\
& \text { fruit it not become ept } \\
& \text { 'It has not yet borne fruit.' }
\end{aligned}
$$




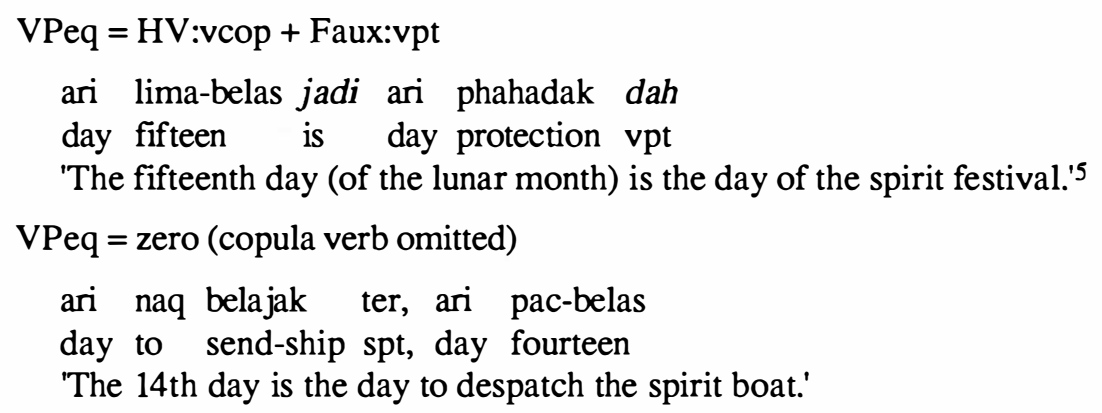

\subsubsection{Verbs of saying and perceiving (vsp)}

These verbs are a sub-class of the action verb, whose Object may be an embedded utterance. This utterance may be as brief as one word, or it may be an utterance of any length. These utterances may be introduced by the final subordinating conjunction /caq/ 'that ....', and may be: terminated by a syntactic particle, such as /ter/ or /ni/. This will be discussed in more detail in a subsequent paper on UL clause level.

VPac $=H V: v s p$

haja nya melaw "Bisemilah" duhulu
habitually she say "Bismillah" first
'Habitually she says "Bismillah" first.'

nya melaw jangan bini caq; "kaw tengaq nasi kaq ku; ...."

he said to his wife that, you cook rice for me

'He said to his wife, "Cook some rice for me; ...."'.

Sometimes the embedded utterance may be the title or topic of a narration:

$$
\begin{aligned}
& \text { VPac }=\text { Aux:apt }+\mathrm{HV}: \mathrm{vsp} \\
& \text { ini, naq melaw; lagu koq semiya brubac urak sakëq } \\
& \text { now will tell; story the man makes-medicine man sick } \\
& \text { 'Now I will tell the story of the man who uses witchcraft for sick people.' }
\end{aligned}
$$

\subsubsection{Possible passive construction}

In my earlier article (1978:20, 23), I referred to a construction with the word / $\mathrm{kena} /$ as a passive auxiliary particle appearing in the Aux: slot, in contrast with its normal position as a verbal auxiliary in the Modal Auxiliary slot. As an action verb/kena/ means 'to contact, to experience, to hit off exactly'. As a verbal auxiliary it means 'must'.

$\mathrm{VPac}=\mathrm{HV}: \mathrm{vac}$

kena besi tajap; luka

contact iron sharp; wounded

'We contact sharp iron which wounds us.' 
$\mathrm{VPac}=\mathrm{HV}: \mathrm{vac}+$ Faux:vpt

kena dah

contact vpt

'That is correct.'

VPac $=$ Maux:vaux + HV:vac(2)

kami kena pi mengayën

'We must go fishing.'

Of the 46 occurrences of / $\mathrm{kena} /$ in the computer text, only three could be interpreted as being passives.

kaw hoy semengac; kaw kena mati dah

you have-no spirit; you must die vpt

OR you have-no spirit; you experience die vpt

'When your spirit goes, you are dead.'

dah kaw hoy semengac; kaw kena mati ler dah

when you have-no spirit, you must die ept vpt

OR when you have-no spirit, you experience die ept vpt

'When your spirit goes, you are dead.'

bena tët kena rigaq dah; baru naq carëq

matter not experience arrest vpt; now will tell

'Now I will tell the story of not being arrested.'

Of these only the third one appears to be potentially a passive. The first two cannot be true passives, as /mati/ 'to die' is an intransitive verb. The sentences must be accepted as active sentences, with the modal auxiliary bearing either of the meanings shown. In the fatalism of the UL world-view, the words 'must' and 'to experience' are basically one in meaning, as what we experience is what must happen to us - it is our fate.

In the third example, it is possible to supply the missing actor as being a policeman; e.g.:

bena nu tamata rigaq dah; ...

matter which policeman arrest vpt

This changes the emphasis of the sentence to concentrate on the action of the policeman, rather than on the experience of being arrested. It seems more logical to interpret the word $/ \mathrm{kena} / \mathrm{as}$ here having the meaning 'to experience', and being either a modal auxiliary or the first action verb in a cluster.

Therefore it is concluded that in $\mathrm{UL} / \mathrm{kena} /$ is not a passive marker. 


\subsubsection{Tense indication}

It should be noted that the UL verb has no indication of tense, and no concord for number or gender. Four particles in the verb phrase are used to indicate tense:

a. The auxiliary particle /naq/ speaks of intention, or of a future action, similarly to <will $>$ in English.

ku naq pi kaq lawoc

'I will go to sea.'

b. The verbal particle /dah/ speaks of something as past, but also speaks of something as being definite.

nya baliq dëq lawoc dah
he come-back from sea past
'He came back from the sea.'

nya naq baliq dah

he will come-back past

'He will definitely return.'

c. The auxiliary particle/tengah/ describes a continuous action, generally in the present.

nya tengah tinoq ni

'He is sleeping now.'

d. The auxiliary particle /ada/ describes a continuing state.

kita ada bajiq

'We are well.'

The modal verb /sudah/ is used to indicate past tense, and the modal verb /belëh/ also is sometimes used with this meaning. There are also adverbial expressions, which give an indication of the time of an action, while conjunctions often show the relative time between adjoining clauses.
sudah
menyukën ter; pi naq juwan
have scraped-out spt; go to sell
'We have scraped out the shells and will go and sell the shellfish.'
nya tët belëh makat nama
it had-not got eat anything
'It (the snake) had not eaten anything.'

\subsubsection{Prepositional phrase}

The Prepositional Phrase (PP) is a relator-axis phrase which acts as the filler of various adjunct slots at Clause Level. It may also be layered to fill the Modifier or Possessor slot in the noun phrase. It has either a single preposition or two related prepositions acting as the relator, preceding a noun or noun substitute acting as the axis of the phrase. The formula for this phrase is as follows: 


$$
\begin{aligned}
& \mathrm{PP}=+ \text { Rel:ppt } \quad+\text { Ax:NP } \\
& \text { prep } \\
& \text { ppt + prep } \\
& \text { Here Rel: = Relator } \quad \text { Ax: }=\text { Axis } \\
& \mathrm{NP}=\text { Noun Phrase (which includes nn and pn) } \\
& \text { ppt preposition particle } \\
& \text { prep specific preposition } \\
& \mathrm{nn} \quad \text { symbol for nouns collectively, as in Section 4.1.1.1 } \\
& \text { pn symbol for pronouns collectively, as in 4.1.1.1 }
\end{aligned}
$$

As explained in Section 3.2.2.4.9, the Relator slot may be filled by either ppt or prep standing alone, or by the ppt + prep combination.

$$
\begin{aligned}
& \text { PP = Rel:ppt + Ax:nn } \\
& \text { nya lari dëq api } \\
& \text { it run from fire } \\
& \text { 'It ran from the fire.' } \\
& \text { PP = Rel:prep + Ax:nn } \\
& \text { nya masoq dalap guni } \\
& \text { it enter inside sack } \\
& \text { 'It went into the sack.' } \\
& \text { PP = Rel:(ppt + prep) + Ax:nn } \\
& \text { bini naq nya jengöq dëq dalap guni } \\
& \text { wife of him looked at inside sack } \\
& \text { 'His wife looked into the sack.' } \\
& \text { PP = Rel:ppt + Ax:NP } \\
& \text { angën, nya dudoq dëq hidok kita } \\
& \text { breath, it lives in nose of us } \\
& \text { 'Our breath, it lives in our nose.' } \\
& \text { PP = Rel:ppt + Ax:ppn } \\
& \text { toq dëq kami buwac } \\
& \text { grandfather of us make } \\
& \text { 'Our grandfather made it.' }
\end{aligned}
$$

\subsubsection{Coda}

The Coda (Co:) is a group of particles which operate like a phrase in the clause structure, as they always occur together clause-finally. These particles are as follows:

a. The verbal particle (vpt), as described in Section 3.2.2.4.8. Syntactically, these are fillers of the Faux: slot in the verbal phrase (Section 4.1.2.2.5), but phonologically they are located as the first component of the Coda slot at Clause Level. 
b. The syntactic particle (spt), as described in Section 3.2.2.4.7. It functions in the Coda of a clause to show the relationship of that clause to the other clauses in the sentence.

c. The emphatic particle (ept), as described in Section 3.2.2.4.7. It serves to give emphasis to the clause as a whole.

The formula for the Coda follows, showing the potential fillers of the various slots and their meanings:

\begin{tabular}{|c|c|c|c|c|c|}
\hline Co: $=( \pm v p t$ & & $\pm \mathrm{spt}$ & & $\pm \mathrm{e}$ & \\
\hline & benefactory & & comma & er & emphasis \\
\hline buwak (dah) & final & pot & comma & ëq & ditto \\
\hline & past, decisive & & 'like this' & lah & ditto (MLW) \\
\hline habih (dah) & completed & singi & 'like that' & ler & ditto (strong) \\
\hline lepas (dah) & freed & & & & \\
\hline suc (dah) & finished & & & & \\
\hline sudah (dah) & finished & & & & \\
\hline
\end{tabular}

The following examples illustrate the occurrence of the Coda:

Co:(vpt + ept $)$

nya turot cäw pi kaq Tökkha buwak ler

they descend row go to Phuket finally ept

'They got into their boat and rowed to Phuket.'

Co:spt

kanyaw krerja dëq lawoc ni; belëh senang dah you work at sea like-this; can be-at-ease vpt

'When you work at sea like this, you can be at ease.'

kaq hoy prahu pot; höy tët rasa pi

if have-not boat spt; not able to go

'If we have no boat, we cannot go fishing.'

naq baliq singi; höy; tët jadi baliq

will retum just-now; no; not able to return

'When we wanted to retum just now, we were not able to do so.'

krerja lagu dëq lawoc ni, belëh senang

work matter at sea this, get satisfaction

'When we work at sea like this, we are satisfied.'

tana nganga muloc singi, nanaq berkäw

when opened mouth just-now, child screamed

'When (the snake) opened its mouth as just mentioned, the daughter screamed out.'

Co:ept

kami naq pi soq itu ler

we want to go place that ept

'We want to go there.' 


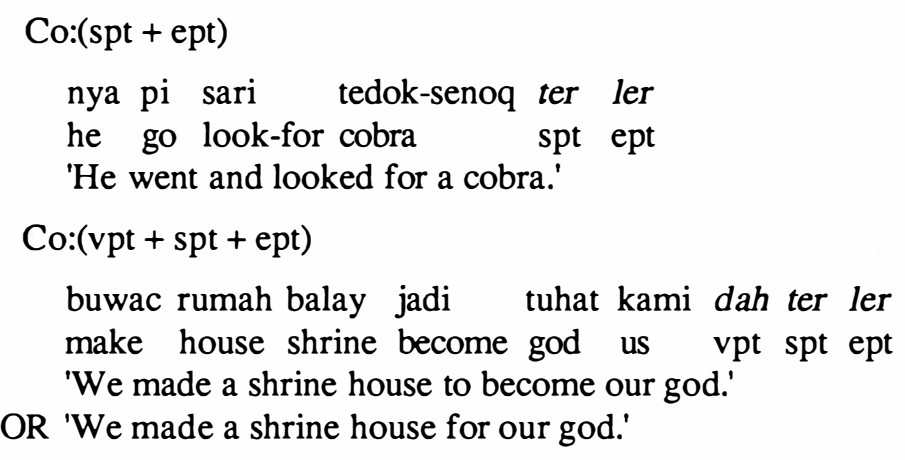

\subsection{Classes of phrase function}

The function of the various types of phrase at Clause Level is outlined briefly here. This will be discussed in more detail in a subsequent paper.

\subsubsection{Function of the noun phrase}

The Noun Phrase functions as the filler of the Subject (Subj:), Object (Obj:) and Complement (Comp:) slots at Clause Level.

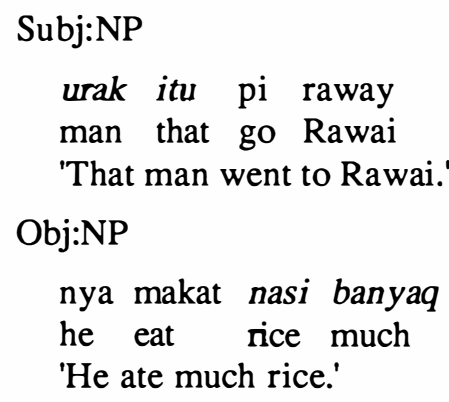

Comp:NP

nya ter urak besing

he spt man Moken

'He is a Moken man.'

The Noun Phrase may also function as the filler of the Modifier slot (Mod:) in the Noun Phrase, or of the Axis slot (Ax:) in a Prepositional Phrase:

Mod:NP

koq nanaq semay ini

the children age this

'Present-day children.' 
Ax:NP

dëq atas prahu ini

at on boat this

'on this boat'

The Noun Phrase may skip Clause Level and function as the filler of the Topic (Top:) or Parenthetical slots (Paren:) at Sentence Level:

Top:NP

lumöh semiya ini, kunya maräh dëq jirac dah group men this, they come from cemetery vpt 'This group of men came from the cemetery.'

Paren:NP

kunya phakhac pi kaq raway: lumöh dibradi ter they together go to Rawai, group relations spt 'The group of relations went to Rawai.'

\subsubsection{Function of the verb phrase}

The Verb Phrase functions as a filler of the Predicate slot (Pred:) at Clause Level:

Pred:VPac

lumöh adi naq pi kaq lawoc

group young sibling will go to sea

'The younger brothers will go to sea.'

Pred:VPst

koq nanaq suka naq budö

the children like to be-stupid

'The children prefer to be ignorant.'

Pred:VPeq

semiya itu jadi urak besing

man that is man Moken

'That man is a Moken.'

\subsubsection{Function of the prepositional phrase}

The Prepositional Phrase may operate as filler of one of the Adjunct slots at Clause Level; i.e. the Location slot (Loc:), the Temporal slot (Tem:), the Manner slot (Man:), the Extent slot (Ex:), the Accompaniment slot (Acc:), or the Instrumental slot (Inst:).

Loc:PP

nya pi kaq raway

'He went to Rawai.' 
Tem:PP

nya naq pi mengayën dëq belakak

'He will go fishing later.'

Man:PP

isi semiya ler jadi rupa mas ler

body man ept become like gold ept

'Amazing, a man's body, just like gold.'

Ex:PP

sekali baliq ter, röc-kaq duwa ratus lebëh: hurak once return spt, as-much-as two hundred over: lobsters

'Once they came back with more than 200 lobsters.'

Acc:PP

nya pi jangan guni sama

he go with sack also

'He took a sack with him.'

Inst:PP

nya timaq jangan terpido

it shot with torpedo

'The submarine shot a torpedo at the ship.'

The Prepositional Phrase may also function as filler of the Mod: or Pos: slots in the Noun Phrase:

Mod:PP

ikat dëq lawoc ler

fish in sea ept

'There are fish in the sea.'

Pos:PP

bini naq $k u$

wife of me

'my wife'

\subsubsection{Function of the Coda}

The Coda is a quasi phrase which occurs as the optional final phrase in any clause. It is filled by one to three particles with the verbal particle modifying the verb phrase (Section 3.2.2.4.8, 4.1.4), the syntactic particle showing the function of the clause in the sentence (Section 3.2.2.4.7), and the emphatic particle showing the relative emphasis of the clause (Section 3.2.2.4.7). 


\section{Co:vpt}

amët bini dah

took wife vpt

'I took a wife.'

Co:spt

sudah menyuken ter; pi naq juwan

finish scrape-out spt; go to sell

'We have scraped out the shells and will go and sell (the shellfish).'

\section{Co:ept}

amët maräh timaw ler

take come construct ept

'We bring the wood and build (the boat).'

$$
\text { Co:(vpt }+\mathrm{spt}+\mathrm{ept})
$$

buwac rumah balay jadi tuhat kami dah ter ler make house shrine become god ours vpt spt ept 'We made a shrine house to become our god.'

OR 'We made a shrine house for our god.' 


\section{NOTES}

1. This chapter constitutes a revision of material presented in the author's 1976 paper 'Urak Lawoi' (Orang Laut)', published in William A. Smalley, ed., Phonemes and orthography, $P L$, C-43. Some additional material has been included, and there are some changes in analysis since that paper.

While most of the material in this chapter is substantially the same as in the 1976 paper, it is not assumed that all readers will have immediate access to the previous work; and the need to present some phonetic detail to assist the reader offers an opportunity to update the earlier information.

2. Abdullah says that Malay vowels occur word-initially and may optionally be preceded by /q/ "in highly formal pronunciation or under conditions of stress" (Abdullah 1974:7-8).

A similar problem exists with the glottal stop in Thai. It is commonly said that a syllable must begin with a consonant, and that a glottal acts as that consonant in a syllable which apparently begins with a vowel; a glottal is also regarded as a permitted final consonant after a short vowel (Haas 1964:xi-xiv). In contrast, Noss (1964:9) says the glottal in Thai is not phonemic, either initially or finally. He says its initial occurrence is determined by the onset of a stress phoneme on a vowel nucleus, and its final occurrence depends on the cessation of a stress phoneme on a short vowel nucleus, that is, one with no final consonant present.

3. The phoneme /j/would be written $/ \mathrm{dj} /$ in the Intemational Phonetic Alphabet.

4. UL has both the Thai loan word / khru/ and their own word/guru/ meaning 'teacher'. These are both in general use, but $/ \mathrm{khru} /$ would tend to be used in referring to a govemment school teacher, while /guru/ would be used more in reference to a teacher of mystic arts, such as a shaman who passes on his ability to someone else.

5. This sentence and that in the following example refer to the spirit festival which the UL people celebrate twice a year at the change of the monsoonal season. In Koq Sireh village this festival commences with /ari meli/ 'buying days', from the eleventh to the thirteenth day of the rising moon, when they buy supplies and liquor, and clothes and toys for the children. The fourteenth day is /ari belajak/ when they release the spirit boat they have built for the occasion. It is made in the likeness of an ancient galley, and loaded with various of ferings from every house in the village. They take it and release it out ot sea, to bear away all their bad luck for the new monsoon season just commencing. Then the fifteenth day is /ari phahadak/ 'protection day', when they plant seven crosses made from bush timber along the beach to prevent the bad luck from coming back to trouble them. The whole season is celebrated with dancing and drinking. They are very insistent that the perpetuation of this festival is essential to their survival as 'Sea People'. The precise observances vary from village to village, depending on the senior witchdoctor of the village. 


\section{REFERENCES}

ABDULLAH HASSAN

1974 The morphology of Malay. Kuala Lumpur: Dewan Bahasa dan Pustaka.

AMON SAENGMANI

1979 Phonology of the Urak Lawoi' language: Adang Island. M.A. thesis, Mahidol University, Bangkok.

AMON TAWEESAKDI (née Saengmani)

1983 ภาษาชาวเล (Urak Lawoi') [= Sea People language]. Bangkok: Mahidol University.

ANNANDALE, Nelson and Herbert C. ROBINSON

1903 Fasciculi Malayenses: anthropological and zoological results of an expedition to Perak and the Siamese Malay States, 1901-1902. Part I (Anthropology) and Supplement. London: Longmans Green.

Anonymous

1971 People of Mainland Southeast Asia (Map). National Geographic, 139/3.

BERNATZIK, H.A.

1958 The spirits of the yellow leaves. London: Robert Hale.

CHOMSKY, Noam

1975 The logical structure of linguistic theory. New York: Plenum Press.

CONRAD, Robert J.

1975 Punch card filing. In Alan Healey, ed. Language learner's field guide, 429-445.

Ukarumpa, Papua New Guinea: Summer Institute of Linguistics.

COOK, Walter A.

1969 Introduction to tagmemic analysis, edited by Samuel R. Levin. Transatlantic Series in Linguistics. New York: Holt, Rinehart \& Winston.

DYEN, Isidore

1965 A lexicostatistical classification of the Austronesian languages. Baltimore: Waverly Press.

ELSON, Benjamin, and Velma PICKETT

1962 An introduction to morphology and syntax. Mexico: SIL.

FRIES, Charles C.

1952 The structure of English: an introduction to the construction of English sentences.

New York: Harcourt, Brace and Company. 


\section{GUDSCHINSKY, S.}

1964 The ABC's of lexicostatistics. In Dell Hymes, ed., Language in culture and society, 612-623. New York: Harper and Row.

HAAS, Mary R.

1964 Thai-English students' dictionary. Stanford: Stanford University Press.

HENDON, R.F.

1960 The phonology and morphology of Ulu Muar Malay. New Haven: Yale University Press.

HOGAN, David W.

1972 Men of the sea: coastal tribes of south Thailand's west coast. Journal of the Siam Society, 60/1:....

1976 Urak Lawoi' (Orang Laut). In William A. Smalley, ed. Phonemes and orthography: language planning in ten minority languages of Thailand, 283-302. PL, C-43.

1978 Urak Lawoi', Malay and Thai: some syntactic comparisons. Te Reo \#21:15-33. Auckland.

LEBAR, Frank M., Gerald C. HICKEY, \& John K. MUSGRAVE

1964 Ethnic groups of mainland South-East Asia. New Haven: Human Relations Area Files Press.

LEWIS, M.B.

1947 Teach yourself Malay. London: Hodder and Stoughton.

1969 Sentence analysis in modern Malay. Cambridge: Cambridge University Press.

LONGACRE, Robert E.

1964 Grammar discovery procedures. The Hague: Mouton.

MALMBERG, Bertil

1963 Phonetics. New York: Dover Publications.

NIDA, Eugene A.

1949 Morphology: the descriptive analysis of words. Ann Arbor: University of Michigan.

NOSS, Richard B.

1964 Thai reference grammar. Washington D.C.: Foreign Service Institute.

PAYNE, E.M.F.

1970 Basic syntactic structures in standard Malay. Kuala Lumpur: Dewan Bahasa dan Pustaka.

PIKE, Kenneth

1947 Phonemics: a technique for reducing languages to writing. Ann Arbor: University of Michigan.

PIKE, Kenneth and Evelyn PIKE

1977 Grammatical analysis. Dallas: SIL. 
SAMARIN, William J.

1967 Field linguistics. New York: Holt, Rinehart \& Winston.

SOPHER, David E.

1965 The sea nomads. Memoirs of the National Museum 5: Singapore.

SORAT MAKBOON

1981 Survey of Sea People's dialects along the west coast of Thailand. M.A. thesis, Mahidol University, Bangkok.

SUDARAT LEERABHANDH

1984 Phonological reconstruction of Proto Orang-Laut. M.A.thesis, Mahidol University, Bangkok.

THOMAS, David

1983 An invitation to grammar. Bangkok: SIL \& Mahidol University.

VEENA, Chantanakomes

1980 A description of Moken: a Malayo-Polynesian language. M.A. thesis, Mahidol University, Bangkok.

VICHIN PANUPONG

1970 Inter-sentence relations in modern conversational Thai. Bangkok: Siam Society.

WHITE, Walter G.

1922 Sea gypsies of Malaya. London: Seeley, Service.

WILKINSON, R.J.

1948 An abridged Malay-English dictionary (Romanised). London: Macmillan.

WINSTEDT, R.O.

1972 Unabridged Malay-English dictionary. Kuala Lumpur: Marican \& Sons. 


\title{
URAK LAWOI' - ENGLISH DICTIONARY

\author{
by David W. Hogan and Stephen W. Pattemore
} \\ with the assistance of Amon Taweesakdi
}

\section{INTRODUCTION TO DICTIONARY}

\author{
by David W. Hogan
}

This dictionary is prepared as a supplement to "Basic Structures of Urak Lawoi", which describes the phonemes, words and phrases of Urak Lawoi', with emphasis on the Phuket Old People dialect.

In preparing this data for publication I have been assisted by Stephen W. Pattemore, who has prepared the necessary computer programs, and has checked the data in considerable detail. The data has also been checked by Ajarn Amon Taweesakdi of Mahidol University, Bangkok, who is preparing a companion dictionary giving the Thai glosses of the Urak Lawoi' words, for publication by the University.

The abbreviations used in the dictionary are as listed in the grammar, except that the dictionary uses " $\mathrm{C}$ " for Chinese loan-words, " $\mathrm{E}$ " for English ones, "M" for Malay ones and " $T$ " for Thai loan-words. It uses the abbreviation "A" for the Southern or Adang dialect, "O" for obsolete words, "On" for onomatopoeic words, and "V" for vulgar words. Where two vowels in an Urak Lawoi' word are separated by a fullstop it indicates a vowel sequence with the two syllables concerned not separated by a glottal stop.

The information listed in this dictionary comprises the following fields:

1. The Urak Lawoi' word in phonemic script in bold.

2. The abbreviation for the part of speech.

3. The English gloss, with the most common meaning first.

4. Supplementary information and related words. Where the insertion of examples or other materials goes into a subsequent line that line is indented.

Where a word operates as more than one part of speech it is listed separately for each part of speech with superscript numbers after the Urak Lawoi' word. Where a word has more than one meaning for the same part of speech, they are shown in the same entry with the different glosses separated by a comma ",".

Under the heading of "related words", alternative spellings are shown in the form "see -----" where that spelling is the preferred usage, and in the form "also -----" where either spelling is correct. All possible spelling variations are not included as there are minor dialectal differences between villages and even between individuals in the same village. Details of some of the 
variations are described in Notes on Pronunciation. Also under the heading "related words", stem words are followed by a list of the various affixed forms of that stem. Where an entry of a prefixed word experiences morphophonemic variation which makes the original stem uncertain, then the stem word is listed as a "related word". All possible forms are not included as some of the prefixes are very productive.

After some words a reference is given "See Appendix", indicating that further detail on points of anthropological interest will be found in the appendix.

A brief English-Urak Lawoi' finderlist is given to assist in finding entries in the main dictionary.

I wish to acknowledge the considerable help which my wife, Doreen, has given in the preparation of this dictionary. Finally, I must acknowledge my indebtedness to the many members of the Urak Lawoi' tribe who have helped in this compilation and in particular, Nai Wong of Ko' Sireh village, Phuket, whose recent death has deprived me of a real friend and an able translation helper.

DAVID W. HOGAN

Phuket, Thailand.

19th December, 1986 


\section{NOTES ON PRONUNCIATION}

Phonemic consonants used syllable-initially in this dictionary are $/ b c c h d g h j k k h l m n n y$ $n g p$ ph $r s t$ th $w y /$. The consonants represented by the digraphs/ch kh ny ng ph th/ are listed in normal alphabetical order under the consonants $/ c k n p t$. The syllable-final consonants are $/ p t c$ kqm nng shl rw y/.

These consonants are described in detail in Section 2.2.1 of the grammar but briefly it may be said that they approximate the equivalent pronunciations in English with the following exceptions:

1. Initial $/ p t c \mathrm{k} /$ are unaspirated stops similar to the second occurrence of $/ p t c h \mathrm{k} /$ in the English words 'paper', 'title', 'churches' and 'kicker', while / $p h$ th $\mathrm{ch} k \mathrm{~h} / \mathrm{are}$ aspirated stops similar to the first occurrence of / $p t c h k /$ in those words. Syllable-finally / ptck/ are unreleased stops.

2. The glottal stop / $q$ /is not a phoneme syllable-initially but occurs syllable-finally. Where a syllable ending with a vowel is followed by another commencing with a vowel, the vowel sequence is separated by a fullstop.

3. Syllable-final $/ \mathrm{c} /$ is phonetically $[i q]$ while syllable-final $/ s /$ is phonetically [ih].

The phonemic vowels in dictionary order are $/ \ddot{a}$ a ë e $i \ddot{o} o u /$. Of these /ä/ and lël represent the low and mid front vowels $[\varepsilon]$ and [e], while /ö/ represents the low back vowel [0]. The phoneme /e/ is phonetically the indeterminate vowel [a]. Full details of the vowels are given in Section 2.2.2 of the grammar.

Different speakers use $/ i /, / \dot{i} /$ or $/ \ddot{a} /$ for the same word or have similar variations with $/ \omega / / 0 /$ and $/ \ddot{o} /$. Older speakers use an initial $/ j /$ in a syllable which other speakers pronounce with $/ y /$. Similarly some speakers commence a word with a vowel where others prefix the vowel with $\mathrm{h} /$. With final consonants, a final $/ /$ is frequently omitted after a front vowel and is pronounced $/ y / a f t e r$ other vowels by speakers of the Phuket Young Peoples dialect. The Southern dialect of Urak Lawoi' pronounces syllables written with $N$ after a mid or back vowel as /er/. Words written with a final /ah/are sometimes pronounced /aq/. There is fluctuation between initial consonants $p h /, / p /$, and $/ b /$ as seen in the word /berhagiq/'share' which may also be pronounced /phahagiq/, or the word/pelacak/'ship festival' which may be pronounced /belacak/. There is also some abbreviation of the initial syllables as described in Section 2.5.1, so that /telaga/'well' may become /tlaga/or/taga/, while /blumok/'funnel, exhaust' may be pronounced /belumok/or /bumok/.

There are also variants in pronunciation due to nasalisation, which occurs when syllables commencing with $/ w /$ or $/ y /$ follow a syllable commencing with a nasal consonant. So /mawös/ 'spring out of water' may have the $/ w /$ so heavily nasalised as to be pronounced [mamös], while /mengayoh/which comes from the stem /kayoh/ 'paddle' is frequently pronounced with the $/ y /$ nasalised so that the word becomes [menganyoh]. 


\section{DICTIONARY ABBREVIATIONS}

\begin{tabular}{|c|c|c|c|}
\hline A & Southem or Adang dialect & ipn & indefinite pronoun \\
\hline $\mathrm{Ab}$ & Abbreviation & $\mathrm{mpt}$ & modal particle \\
\hline $\mathrm{C}$ & Chinese loanword & nab & abstract noun \\
\hline $\mathrm{E}$ & English loanword & nc & common noun \\
\hline M & Malay loanword & nca & common noun, animate \\
\hline $\mathrm{O}$ & Obsolete word & nch & common noun, human \\
\hline On & Onomatopoeic word & nci & common noun, inanimate \\
\hline $\mathrm{T}$ & Thai loanword & $\mathrm{ncl}$ & noun cluster \\
\hline UL & Urak Lawoi' & nco & coordinated nouns \\
\hline V & Vulgar word & neg & negative word \\
\hline apt & auxiliary particle & $\mathrm{nn}$ & nouns of all classes \\
\hline av & adverbs of all classes & np & proper noun \\
\hline ava & adverb of accompaniment & npl & proper noun, locational \\
\hline ave & adverb of extent & npp & proper noun, personal \\
\hline avi & adverb of instrument & num & simple or complex numeral \\
\hline avl & adverb of location & pn & pronouns of all classes \\
\hline avm & adverb of manner & ppn & personal pronoun \\
\hline avq & adverb of interrogation & ppt & prepositional particle \\
\hline avt & adverb of time & prep & specific preposition \\
\hline $\mathrm{cc}$ & coordinating conjunction & $\mathrm{pt}$ & particle \\
\hline $\mathrm{cl}$ & classifier & qpn & interrogative pronoun \\
\hline $\operatorname{clm}$ & classifier, metrical & qpt & interrogative particle \\
\hline $\operatorname{cln}$ & classifier, numerical & res & response word \\
\hline cpt & conjunctive particle & rpn & relative pronoun \\
\hline cs & subordinating conjunction & spt & syntactic particle \\
\hline $\operatorname{csf}$ & final subordinating conjunction & vac & action verb \\
\hline dpn & demonstrative pronoun & vaci & action verb, intransitive \\
\hline dpt & final determiner particle & vact & action verb, transitive \\
\hline dpti & initial determiner particle & vaj & adjectival verb \\
\hline ept & emphatic particle & vaux & auxiliary verb \\
\hline exc & exclamation & vcop & copula verb \\
\hline excl & $\begin{array}{l}\text { pronoun which excludes the person } \\
\text { addressed }\end{array}$ & voc & vocative \\
\hline incl & $\begin{array}{l}\text { pronoun which includes the personal } \\
\text { addressed }\end{array}$ & vsp & verb of saying or perceiving \\
\hline
\end{tabular}




\section{URAK LAWOI'-ENGLISH DICTIONARY}

A

a exc exclamation

abol vact swear, curse; see also supah

abu vact lower

acop $v s p$ incite (to evil)

beracop

ada $^{1} v c o p$ be

Ada koq barak There are the goods.

Ada ler koq raja There is the king.

ada $^{2}$ vact have, be at, exist

Nya ada nanaq radara $\mathrm{He}$ has a daughter.

Nya ada dëq atas dah $\mathrm{He}$ was above. Asan nya ada dëq lirak Satak His origin was at the place Satak.

$\mathbf{a d a}^{3}$ apt in a state of

Ada dudoq peq itu lama-lama $\mathrm{He}$ had been living there for a long while.

adi nch younger sibling; cf. miq voc

adi-bradi relations; also dibradi

ados exc cry of pain or distress

ados-adoy repeated cry of pain or distress.

(When repeated more than once, 'ados' occurs the first time only, with 'adoy' for each subsequent repetition).

adoy exc cry of pain or distress; see ados

adu $^{1}$ vsp accuse

pasan kena adu accusation adu caq nya batah accused him of being stubborm

adu tët kena lagu unjust accusation

$\operatorname{adu}^{2} c s$ if

Adu nya bercaya, nya pi soq jalat sepäq singi If he believes, he goes by this narrow road.

a.ëq $n c h O$ mother (normally ët)

agah vact mock

agah gelaq laugh at agöq nci locket

ajal vact teach; belajal

ajaq $v s p$ invite, tempt; berajaq, me.ajaq

ajök vact criticise

akal nci runner, root

akal bahal marine growth used for decorative purposes

akan vaj wise, intelligent

ba.akan, berakan

berakan self-willed (of a naughty child)

akëq vact lift, erect, carry (with the hand);

berakëq

akëq asan pronounce a curse

akëq bubu raise a fish trap

akëq sawoh raise the anchor

akëq tangan wave the hand (in greeting)

akoc vact carry, lift up (a quantity);

berakoc

aku ppn $M$ I

alëh vact turn something; change; beralëh

alu vaci howl (of animals)

amac ave extremely

amët vact take

amët maräh bring

amët mukha seek the respect of others

amët pi take away

amët salah catch in a fault

ampher nci $T$ district

amu vact rob

anamay $n p l T$ Government health clinic

anaq nca young of animal; beranaq; occasionally used for children, but 'nanaq' is normal word for children.

bela cucu anaq care for young relations

anaq bras small portions of rice (used in ceremony) 
anaq buwah employees

anaq kuci key

angaq vact threaten, make threatening gesture (with knife or stick)

angaw vact reach out

angën $n c i$ wind, air angën bernyawa air to breathe angën kurak wind abates angën tegal strong wind angën tudoh wind drops ijën angën air compressor jadi angën feel faint regu angën blow (human)

angën barac daya southem wind (dangerous)

angën jarop panaq south-west wind

angën selatat south-east wind. These three southem winds all produce large seas but 'barac daya' the southerly wind produces larger and more dangerous waves

angoq vact nod, greet angoq pala nod head in assent

angun $n c i$ grape ayë angun wine, grape juice

anoy see 'noy-anoy' white ants

anu exc interjection (referring to something unknown or forgotten)

anyam vact weave, bind (e.g. a bamboo floor with cord)

apa ipn $M$ anything

apal vact spread out (planks, slats, etc.) apal latay lay a slat floor apal lepac spread out a sleeping mat apal papat lay a plank floor rumah prabok apal flat-roofed house

api $n c i$ fire; berapi api neraka hell api röntri projector lamp api suwal projector lamp lungoq api large blaze tali api radio aerial tanah piyoh api gunpowder

apoh vact flood ayë apoh flood waters

apok nch father apot $v s p M$ forgive

apu vact carry in the hands (in front); see junyok

araq $n c i$ whisky, spirits makat araq drink spirits

ari $n c i$ day ari pelacak day of spirit festival for floating spirit boat (see appendix) ari phahadak day of spirit festival for planting crosses (see appendix)

bilak ari every day

krerja dëq ari work in the heat mata.ari sun sa-ari-ari each day

ari-ari avt daily, every day ri.ari daily

ari ter $n c i$ that day (just before)

arök nci open sea, ocean

asah vact sharpen

asan $^{1}$ nab origin, beginning usoq asan origin, source

asan $^{2}$ nab/vsp curse, wish asan belëh dikiq banyaq pot jadi Hope to get little or much, even, it will do asan jadi sungoh Hope it will surely happen

asan mati "Let him die!"

asan menyari mudah, baliq naq tabol bras kunyäq Hope to find it easily, on returning will sprinkle yellow rice

asan tët belëh, naq tabol bras

kunyäq Hope he does not get anything, (then) I will sprinkle yellow rice nya akëq asan jaq He pronounced a curse that....

asan $^{3}$ vact implore, beg

asap $^{1}$ vaj bitter

asap $^{2}$ nci tamarind tree asap kelubi kind of plant

asap kumal kind of palm

asap telinga kerbaw kind of fruit

ayë asap orange drink

asap limaw nipih limes

asap limaw manëh orange

asap limaw hurak pomelo 
asaq nci smoke

asën nci tax pungöc asën collect taxes tepac pungöc asën tax office

asik vaj other asik dëq kawat different from others nanaq asik-asik other children taqasik oneself

asu nca dog lulu asu 'dog's meat', calf of the leg

atac vact send; accompany atac hatu go in a funeral procession

atas prep on, above, in

atas kranyak on the box atas rumah in the house dëq atas prahu on the boat langäq dëq atas sky above ruwak atas mata.ari inside room

awac nci oar; berawac

awaq npl Burma, Burmese sami awaq Burmese priest

aya $n c a$ female (animal)

ayaq vact jerk a fishing line

ayë $n c i$ water

ayë asap orange drink

ayë batu ice

ayë ba.u perfume

ayë belay water bubbling up

ayë besal spring tide

ayë brernäh water bubbling

ayë dada mother's milk

ayë dras turbulent water

ayë höy dras water, not turbulent

ayë krik low tide

ayë lemu incantations (see appendix)

ayë liyol spittle

ayë mata tears

ayë mati neap tide

ayë menidëh boiling water

ayë minäq soft drink ayë pasak rising tide

ayë penöh high tide

ayë sengaq calm water (in a pool, etc.)

ayë suroc falling tide

ayë tenang calm water (at sea)

ayën $n c i E$ iron

ayut nci swing, hammock; berlayut

usiq ayut play on a swing

\section{B}

bäq ${ }^{1} n c i$ box, bag (for clothes, etc.)

bäq $^{2}$ nca goat

ba.ados vac making sounds of distress; also berados

ba.ajaq vact invite

ba.akan vac clever, wise

ba.aq vaj damp

babi nca pig

bac nci $T$ baht

baca vact read, recite

baca ayë lemu make incantations

badaq nca rhinoceros

badat nci corpse, spirit of the dead

baday see cay-baday scattered

bagat pulaw $n p l$ village on Lanta Island

bahamac vact receive; hamac

bahana vaci roar (of sea)

bahati vaj sorrowful

bahaya nca crocodile

bahoq vact cut down, slash

bahu nci shoulder

baji nci wedge (wood or iron)

bajiq vaj good, well

bajiq sesungoh truly good

jiq-bajiq avm well

bajiq-bajiq vaj reconciled

bajiq-hati $v a j$ good hearted 
bajiq-tepac vaj righteous

baju nci coat, blouse

baju koc long outer garment

baju teban pullover

bakon $n c i$ rice sack (large)

baksa $n c h$ race, nationality baksa urak lawoc Urak Lawoi' race urak luwal baksa foreigner

baksac vaci wander

balac nci mooring

balak see hulu-balak royal official

balas vac repay

balay $n c i$ royal residence

balay datoq spirit house

baliq vac return

baloc vact roll up

balol $n c i$ weal from beating, jellyfish wound

bangac vaj quick ngac-bangac avm quickly

bangköq $n p l$ Bangkok

banyaq ipn much, many sebanyaq-banyaq great quantity semiya banyaq-banyaq crowd dikiq banyak little or much

banyaq dëq kawat more than others banyaq lagi more

banyaq sungoh very many

banyaq terlalu exceedingly many

banyaq-banyaq ave much

bapa $n c a$ male animal

baq $n p t$ particle of request

baqbuq karak type of fish

barac nci west

barac daya south

barah vaj swollen

barak nci goods, belongings sebarak goods

bena barak goods of all kinds barak makat food

barak matay jewellery

barak tët guna evil behaviour

bari vaj sour, spoiled (food)

baroc nci scar

baru $^{1}$ vaj new

baru $^{2} c c$ then

basa $n a b$ manners, language

budi basa gracious, courteous

höy basa no manners

basah vaj wet

basan vaj swollen, oedema

basoh vact wash, cleanse

batah vaj stubborn, naughty

batak $^{1}$ nci pole

batak $^{2}$ cln classifier (for long objects)

batan nci pillow

batën $n c i$ bowl

batën piraq silver cup

batoq vaci cough

batu $n c i$ rock, stone

batu gilik millstone

batu gudap coral

ba.u nci smell ayë ba.u perfume

ba.u busoq bad smell

bawa vact carry, bring

bawa maräh bring

bawa pi take

bawah prep below

bawoq $n c i$ beard, side-whiskers

baya $n c i$ level, square sama baya equal sebaya equal to

bayak nci shadow

bayal vact pay

bechi vact hate 
bedukak nca catfish (shallow water)

begacaq vaj pretty, handsome

begu avm in pairs

begupok vaci go in groups

bejäq vaj cold, cool; ber jäq jäq-bejäq evening

bekaq prep like, according to

bekaq caq $c s f$ as if

bekas $^{1}$ nci trace, impression bekas jari fingerprint bekas kaki footprint

bekas $^{2}$ vaj leftover, left behind

bekataq nca frog

bela vact care for, heal, rule over; berbela

belacak $n c i$ ship festival; see pelacak

belacat $n c i$ fishpaste; also blacat

belaga vact collide, fight (animals); also blaga

belah $^{1}$ vact split in two, operate on

belah $^{2}$ nci side

duwa belah sungay two sides of a river

sebelah se-urak one on each side

belajal vact study; also blajal

belakak nci back, behind; see blakak

belalok $v s p$ call; see blalok

belanga $n c i$ frying pan

belanga besi frying pan

belanga tanah earthern ricepot

belanya $n c i$ living expenses

belas num -teen

sebelas eleven

duwa belas twelve

belatoq $n c a$ woodpecker; also blatoq

belëh $^{1}$ vact get, obtain; mebelëh, berbelëh

belëh ${ }^{2}$ vaux be able to

berbelëh ler well able to

belëq vact twist (rope, etc.)

belekac api light a fire; also plekac api beli vact buy

belibas vact $O$ serve

belihac vaci revealed; see plihac

belikal vaci squat (man or animal); coil (snake)

belirak $n c i$ sulphur

belitak vaj crossed; see plitak kayu belitak see plitak

beloc $n c a$ eel

belumäq babi balloon

belumok nci funnel, exhaust pipe; also blumok

belumus vact cover head with a blanket

bemanëh $n c i$ sweet potato

benäh $n c i$ seed, offspring

bena $n c i$ thing, matter

bena barak goods of all kinds

benak $n c i$ wet rice field

benal vact entrust to someone, permit

benang nei thread, cotton

benang löq string made of cotton (used for takan)

benang nyahëq cotton

benasa vaj broken, spoilt

benatak nca animal

beni-brani vaj bold

benuwa nci world, country

ber $n c i T$ lottery ticket usiq ber playing the lottery

beracop vac inciting

berados vac making sounds of distress; also ba.ados

beradu stop; see bradu

berajaq vact invite; also ba.ajaq

berakan vac intelligent, self-willed (of a naughty child); akan

berakëq vac lifting

berakoc vact lifting, carrying; akoc 
beralëh vac tuming (oneself); also bralëh

beramay vac keeping festival, having fun; also bramay

beranaq vac having young; also branaq asu beranaq pregnant dog telol beranaq egg with chicken

berapas vaj grasping; rapas

berapi vac burning

beratac vact accompany (someone or something)

berawac vac rowing; awac

berbac vact wrap around

berbagat vact stay temporarily

berbaliq vac take back

berbasa $v a j$ well-behaved

berbayak-berbayak $v s p$ see as shadows

berbejäq vaj feeling cool

berbela vact care for, heal, rule over

berbelah vaj dumb and simple

berbelëh $v a c$ able to; belëh

berbikas vact raise up

berbini vac taking a wife

berbradu vac stopping

berbuwac vac making

bercahi vac mixing

bercat vact arrange

bercaya vact believe

berdabu vaj dim (of sight)

berdahaq nci comer

berdapac vac meeting with

berdenang vaci swim

berdepa vaj with arms outstretched; depa

berdi.ak vact warm oneself

berdiri vac stand; diri

berdusa vaj sinful

berga see brerga value

berganyaq vaci moving; ganyaq bergarap vac salted

bergari vact see

bergelaq vaci laughing

berguna vaj useful höy tët berguna useless, evil

berguru vaj expert, learned (especially in magic art)

berhagët $n c i$ share; hagiq (see phahagët)

berhidoq vac living

berhimac $v s p$ think about, be concemed about

berhimac nyawa taqasik be selfish

berhun vaci partnering

beringac vac considering

beringöq vac shake, tremble tanah beringöq earthquake

berinok vaj infected

berisi vac containing

berjadi vac make, create, be born

ber jahul vaci blazing up

ber jakal $n c i$ foundation, origin

ber jalat vac walking; jalat

ber janyi $v s p$ promise (to)

berjula $n c i$ violin

berkäw vaci scream; see brerkäw

berkac vaj alight

berkahi vact quarrel

berkali avt sometimes

berkata vac $M$ saying

berkhanaq vac desire, need; khanaq

berkira vac discuss together

berkoq vact assemble; see brerkoq

berkraq vac stick together, adhere, fasten on, set in (stone)

berkrerja vac working

berkudën $v a c$ itching with skin disease

berkuraq vac covered with a skin disease 
berkutök-kutök ave in long lengths

berlaboh vact anchor

berlalok $v s p$ call; also blalok

berlarak $v s p$ forbid; also blarak

berlari vac running; also blari

berlawat vac oppose, resist; also blawat

berlayal vac sailing; also blayal

berlayut vact swing

berlihac-lac vac looking around

berliyak vaj wounded

berluma vac racing

bermäh vaj clean (of the body)

bermakat $v a c$ give food to

bermalu vact curse

bermaräh vact bring, cause to come

bermasaq vact cook, ripen, dry out

bermelaw vac speaking

bermöq vact push into, invade

(undergrowth, etc.)

bermun vaci meet together, gather together

bermuy $n c i$ trunk (of elephant)

bernäk vact embrace

bernama vac named

bernanaq vac having a child

bernati vact waiting

berngaw-berngaw $v a j$ flashing

bernikah vaj married

berniyac vaci carry out a vow

bernyala vac flaming

bernyanyäq vac cause to ascend, raise up

bernyanyi vac singing

bernyawa vac breathing

bernyawa besal sighing

bernyiwa vac renting; siwa

berpakay vac wear (clothes) berpatak vac observe food restrictions (see appendix); patak

berpati nca dove

berpatot vac chant, mourn

berpecah vac breaking up

berpi vact take, cause to go

berprak vac fighting

berprangay vaj orderly, good housekeeper

berproc vac conceive, be pregnant; proc

bersama vac going together bersama-hati united

bersanal vact depending on, leaning on

bersapoc vaci wrapped around

bersatu avt in one case

bersawoc $v s p$ pray, vow

bersaya vac shining

berseri $v a j$ outstanding, beautiful, welldressed

bajiq berseri be handsome

pakay berseri be outstanding

bersiyak $v a c$ lasting until daylight

bersiyaq vac prepare

bersudu vact stir

bersupah vac swearing

bersura vaj shining steadily (a star)

bersuraq vac shouting

bertahat vact abstain from

bertahu see bitahu tell, inform

bertamah vac increase

bertaroh see usiq bertaroh play dice

bertelak vaj $T$ miscellaneous

bertengan $v s p$ boast

bertihac nci echo

bertimon vac refloating

bertudoh-tudoh vact blaming each other

bertulok vact help

bertulok-tulok vact helping one another 
bertunang vaj engaged

bertungu vact watching on guard

bertupah vact spill

berturot vact lowering (a person)

bertuwah vaj lucky, fortunate

berubac vact chant charms, apply medicine; ubac brubac

dët berubac shaman's candle

urak berubac shaman

berubah vact moving (something)

besal vaj great, large

dumiq besal little and big urak sal-besal important man

besal dah grown up

besal maräh grow old

besi $n c i$ iron

(be)sipaku iron nail

besi brani magnet

besi garöc pronged scraper

besi giya gearwheel

besing $n c h$ Moken people

betäw nca spotted shark

betih nci calf of leg, lower leg

betoq $n c i$ prow of boat

bibas vact serve

bibël $n c i$ lips

bibri $n p l$ Pee Pee Island, Krabi province

bicok-bicok vaj uneven, unequal-sided

bida $^{1}$ prep for hagiq ku setengah bida urak sakëq give me some for the sick person

bida $^{2}$ csf so that hagiq ku setengah bida ku na makat give me some so that I will eat

bidak $c l n$ classifier for sheets of matting

bidat $n c h$ local midwife

bidik prep beside

bidik prahu $n c i$ side beam of boat

bidik-bidik avl close by bihak avt dawn

bijëh nci tin ore

biji ${ }^{1}$ nci seed

biji kemangi variety of sweet basil

biji leba sweet basil

biji selasë holy basil (ocium sanctum)

biji2 cln classifier for small objects

bikas vac rise up; berbikas

bikuy $n c i$ kind of tree

bilah $n c i$ kind of wood (used as uprights in Moken boats)

bilak ipn every

bilak ari every day

bilak waqtu all the time

bilakäl $n c h$ ancestors (see appendix)

bilas vaci squint

biming vact carry at side (arm extended)

bini $n c h$ wife laki bini married couple

bisa nci venom, pain

bisemilah exc $M$ 'in the name of Allah'

bisiq $v s p$ whisper

bitahu $v s p$ tell, inform

bitak nci star

bitak bata yay North Star

bitak brasaq shouting star

biyal vact let go, release biyal ler Let it go! Don't worry!

biyas $^{1}$ vaux able to höy tët biyas cannot do it

biyas $^{2}$ nab ability bekaq biyas naq kanyaw according to your ability

biyasa vaux accustomed to, habitually

biyok nca winged insect, beetle

biyok gajah elephant beetle

biyok krerbaw buffalo beetle (edible)

biyok thëq-thëq winged insect 
blacat $n c i$ fishpaste; also belacat

blaga vact collide; also belaga

blajal vaci learn; also belajal

blakak $^{1}$ nci back; also belakak

blakak $^{2}$ prep behind

ari blakak on a later day

dëq blakak later

soq blakak behind

blakak itu later

blakak kaki top of foot

blakak satak seaward side of Lanta Island

blalok vsp call; also berlalok

blanga nci frypan; also belanga

blarak vsp forbid; also berlarak

blari vac running; also berlari

blatoq $n c a$ woodpecker; also belatoq

blawat vac oppose, resist; also berlawat

blayal vac sailing; also berlayal

blumok nci funnel, exhaust pipe; also belumok

böh ${ }^{1}$ vact place, put on

böh ${ }^{2}$ res invitation to act, "Right"; böh implies that the speaker will not participate in the proposed action; cf. joh

bökbrök nci Adam's apple, windpipe

bölä nci $T$ tin dredge

böm vact $E$ dynamite (fish)

böplaw avm $T$ in vain

böräng nci $E$ boring for tin samples

böya $n c i$ stem piece of boat

böya kemudi stern piece

bon-srerbon vaj overcast

boq $^{1}$ nci hair

boq $^{2}$ exc surprise!

bot $n a b$ merit

tehabot make merit

urak bot man with merit

brac vaj heavy

kerja brac work hard bradu vac stop, stay

bradu remay vaci rest

brakëq vact move (a house); akëq

brakoc vact carry; akoc

brala $n c h$ idol

brala takan sacred objects

bralah vact surrender, admit defeat; also beralah

bralëh vact turn, change; alëh

bralëh-hati repent

bramay vac having fun; ramay

brana $^{1}$ nci long drum

brana $^{2}$ vac dance with drum

branaq vact give birth

brani vaj bold

besi brani magnet

nibrani bold

brapa $^{1}$ qpn how many?

brapa $^{2}$ ipn much

brapa $^{3}$ ave very tët brapa lama not very old

bras nci husked rice

tapih bras dëq nyiru winnow rice with basket

jroh bras pound rice

bras kunyäq yellow rice (often used in witchcraft; see tabol)

bras payah rice scarce

brasa vac feel; rasa

brawac vac row (a boat); awac

brerba vaj bushy; reba

brerbiq vact blow

brerda vact slow down (a motor, etc.)

brerga nci value; rega

brergöq nci throat

brerkäw vaci scream

brerkoq vact assemble

brernäh vaj bubbling up

brersët vaci sneeze 


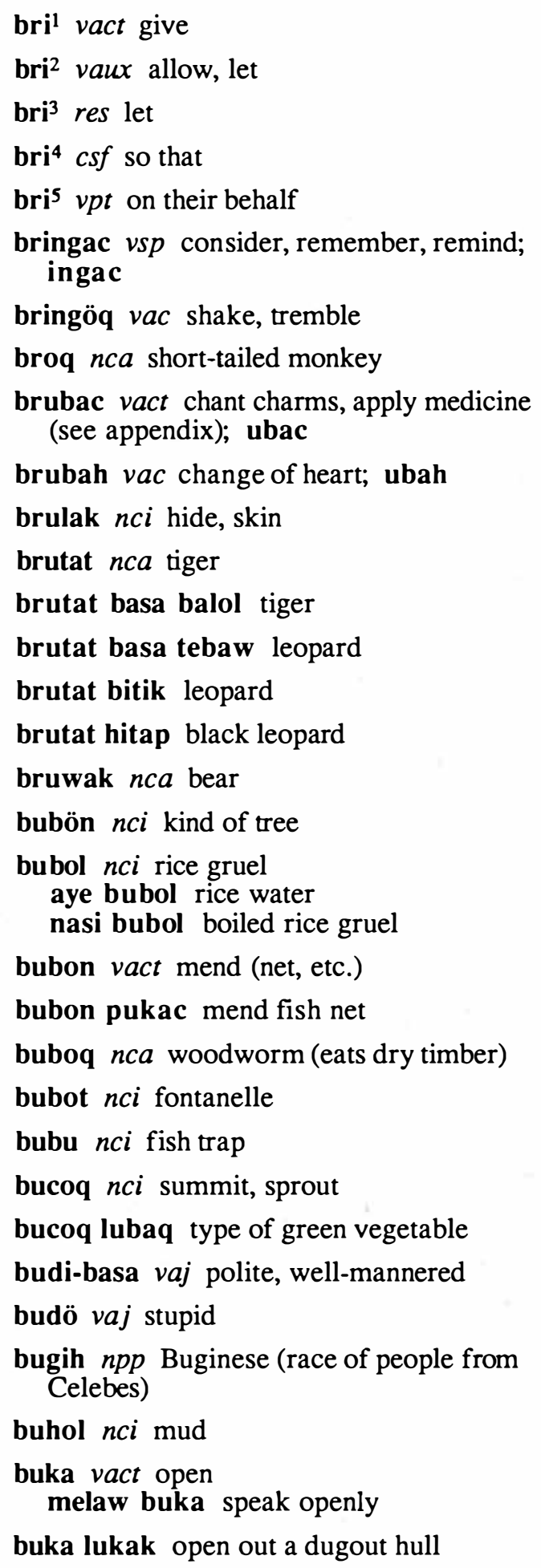

bukan $n p l$ village in Krabi province

bukat neg no, on the contrary

bukat ger Isn't it true?

bukëq $n c i$ mountain, hill

bukoq vaj stooped

buku nci knuckle

bukus nci parcel

bul-ubul $n c a$ white jellyf ish

bulac vaj round pala bulac round head on a Thai letter soq bawah bulac stroke below head (on Thai letter)

bulac pan yak elliptical

bulak kaq ëh have diarrhoea

bulat nci moon, month se.ari bulat (timon) new moon, first day of waxing moon

lapat ari bulat timon first quarter moon bulat penöh full moon lapat ari bulat turot last quarter moon bulat turot lapat kelap last quarter moon

bulat putus last day of waning moon

buloh nci bamboo

buloh menupëq blowpipe

buloh petök bamboo shoots

bulu $n c i$ body hair, fur, feathers

bulu babi type of starfish

bulu daga short beard

bulu lanaq quills of a porcupine

bulus $n c i$ spear, arrow

bumi $n c i M$ ground

bumok (PYP) see blumok funnel, exhaust pipe

bumöl nch doctor, shaman

bumöl berguru practitioner of white magic (U.L.)

bumöl hatu sorcerer, witchdoctor (U.L.)

bumöl lihac groh fortune-teller (Thai)

bumöl lihac khröq medium (Thai) 
bunën $n p l$ village on Lanta Island

bunga nci flower, interest on a loan; berbunga

bungi $n c i$ noise (of engines, etc.); berbungi peti berbungi gramophone

buni vact hide (something)

bunöh vact kill naq bunöh kaq... intending to kill...

bunöh diri commit suicide

buran vaj $T$ ancient

buriq vaci make a noise (human)

burok nca bird

burok ak.ak crow

burok cepelik crow pheasant

burok cicang seagull

burok ciyaq sparrow

burok denak crow

burok hatu owl

burok meraq peacock

burok mrerboq pigeon (small)

burok pati dove

burok tutru pigeon (large)

buroq vaj wom out, rotten (meat, fish, etc.)

bus $n a b$ sound signif ying rapid removal of offending spirit

busoq vaj rotten, smelly (animal matter)

busu vaj last, youngest child

buta vaj blind

kudën buta skin irritation

butik $n p l$ village on Lanta Island

butoc nci female sexual organs

butoc tahi anus

buwac vact do, make; berbuwac

buwac dop carry out a custom

buwac kawat take advantage of

someone

buwac nama Why?

perbuwac actions buwac rubiru vaci behave in objectionable or disgusting way

buwac-berbuwac acting repeatedly

buwah $^{1} \quad \operatorname{cln}$ classifier for large objects

buwah $^{2}$ nci fruit

buwah gula football

buwah hawa Adam's apple

buwah lebac many fruit on tree

buwah pupol berry-like fruit

buwah sipol kind of fruit

buwah telipoq lotus flower

buwak $^{1} v p t$ decisive or final action

buwak $^{2}$ vact discard; terbuwak

buwak lawoc throw into the sea

buwih vact pass by

buyok nci water jar

C

cä nch grandfather

cäq-biräq $a v m$ scattered

cäw vact row a boat (facing forward)

ca nch voc older brother

cabak nci forked stick, step on Moken boat kayu cabak forked piece of wood

cac nci paint

cacaq vact insert

cacaw vaj unsettled, disturbed, confused

caciq kemudi $n c i$ tiller (of sailing ship)

caciq layal $n c i$ boom (of sailing ship)

cadak vaux/vsp hope cadak naq belëh hope to get

belëh cadak nya naq bri can hope he will give

cadok nci comer

cagu nca caterpillar

cahi vact mix; bercahi

caköq vact hook, encircle with arm; menyakö 
penyaköq hooked stick (e.g. for catching lobsters)

cakös vact carry on back

cakon nci hoe

cakon jari pronged hoe

calok nci tin (for dipping out water)

camal nca seagull

cangah vact go against, toss

cangah angën go against the wind

cangah dras go against the current

cangah umaq go against the waves

cangaq nci Moken boat

cap vact remember

capah temaga metal tray

capaq nci chickenpox

capëq vaj lame

capëq-capëq avm limping

capol vact mix

caq $^{1}$ csf that jadi caq means that

krana caq because that

caq $^{2}$ vsp say

caqcaq nca house lizard, gecko

caqcik nca intestinal parasites

cara nci style

carëq $v s p$ tell; (me)nyarëq

cawak nci foundation post

cawak gatok intemal upright in house

cawak seri chief foundation post

cawbaw nch $T$ bridegroom

cawmuang nch $T$ govemor

cawsaw nch $T$ bride

caya believe; see bercaya

cay-baday avm scattered

cëti nch Indian moneylender

cebiq vaci stumble

cebuq vact dip out (water) cehäq vaci keel over

cekäq vact strangle

cekäq lihël stick in the throat

celäq vaj ashamed

celah nci cleft, opportunity

celah bukëq valley

celah jari kaki space between the toes

celaka vaj cursed

celöl vact water, pour on (e.g. flowers)

celuq vact dip, dye

celuq-celaq avm scattered haphazardly

cepac vaj quick

cepac-cepac avm quickly

cerköq vaci capsize; see crerköq

cermën nci glass, mirror; see crermën

certa nci fable, story; see crerta

cerupi nci $T$ engine grease

chiq exc $V$ ejaculation

chiya vact treat (to food or drink)

Chumphön npl Chumpon, S. Thailand

cicäq $^{1}$ nch great-grandchild

cicäq ${ }^{2}$ vaj tom

cicak vact chop up small, lop off

cicang nca small type of fish

cicët $n c i$ ring

cihäq vaj tilted (objects)

cikak vaj taut

cikaq vaj hold between thumb and finger cikaq pingak hands on hips (sign of the boss)

ciköc vact bend (a limb or finger)

cilök npl Chalong, locality on Phuket Island

cina npl China

cipak vact tum aside cipak tiga crossroads

ciyop vact kiss

cöc vact $T$ park (vehicle or boat) 
cöq $n c i T$ cup

crah $^{1}$ nci light

crah pagi in the morning

crah $^{2}$ ave completely

crana $n c i$ betel nut tray (wedding gift)

crerkäq vact throttle

crerköq vact overturn

crerköq terletak capsized and righted

karap cerköq capsized and sunk

crermën $n c i$ glass, mirror

crermën mata spectacles

crermën nyelap diving goggles

crerta $^{1}$ nci fable, story

crerta $^{2} v s p$ tell a story or fable

cröy vaj flat, tasteless, brackish

ayë cröy brackish water

gulay cröy curry lacking flavouring

croh vact pound rice

cubuk nci crown, dancer's headdress

cucoh vact light (cigarette, lamp, etc.)

cucoq vact thread (a needle)

cucoq sangon hair pin to fasten bun (also used to clean ears)

cucu nch grandchild

cudëk nca small grey scorpion (found in house)

cukën vact scrape out

cukhon nca kind of shellfish

cukol vact shave

cukuk vact push

culas nca kind of fish

culat vact tear; terculat

curi $^{1}$ vact steal; menyuri, penyuri

curi $^{2}$ avm secretly

cutëk vact decorate, daub, smear

cutö nab example

cutot vact lead (e.g. a blind person)

cuwäq vact pinch
D

dabu vaj grey; berdabu

dada $n c i$ breast

ayë dada mother's milk

dadak vact grill, barbecue

daga vaj thirsty; also dehaga

dagik $\mathrm{npl}$ island name

dagu nci chin, angle at bottom of prow of boat

dah $^{1} v p t$ finality

dah $^{2} c s$ when

dahani vaci recover consciousness, wake up; see dehani

dahaq dada centre of chest

dahat $n c i$ branch

dak-kadak avt sometimes

dakdak nci motorcycle

daki vaj dirty, sweaty

dalap ${ }^{1}$ prep in

dalap $^{2}$ vaj deep

kelekaq dalap internal organs

damal $n c i$ torch (using resin)

buloh damal bamboo torch (using kerosine)

damaq $n c i$ dart (for blowpipe)

dangaw $n c i$ shelter (as guard post in rice field)

dap nci decorations

dapac vact meet; berdapac

dapik vaj near

dapik-dapik avl close by

daqaq vaci belch, burp

daqaw $n p l$ village on Lanta Island

daqwa nci court case

dara $c s$ when (when unexpectedly late)

dara nya naq marëh kita penac naq nati When will he ever come, we are tired to wait 
darah nci blood urac darah blood vessels

dat $v a j$ in time dat waqtu in time tët dat not enough time tët dat nama not long at all, soon

datak vaci come from

datdat avt immediately

datoq $n c h$ tutelary spirit (see appendix) balay datoq spirit shrine rumah datoq spirit shrine

daw nci place

daw bermun meeting place

daw diha where

daw ini here

daw itu there

daw penyelöq mortar; jelöq

daway $n c i$ wire

dawot nci leaf

dëq $p p t$ at, from, than, of (blood relations only)

dët $n c i$ candle

degak vaci sway in walking

dehaga vaj thirsty

dehani vaci wake up

deki vaj be jealous of

delaq avt ever

tët delaq never

demam nci fever

demiq vaj little; also dumiq

demiq-demiq avm little

demiq-hati offended, angry

demiq-töc very small

denak nca crow

dengal vact hear

deniya nci world

depa nci fathom

padepa avm with hands stretched out deriyat $n c i$ durian dibradi $n c h$ close relations; adi

diha $^{1}$ avq where? which?

nu diha which?

pëq diha where?

pi diha Where are you going?

watu diha when?

diha $^{2}$ ipn anywhere, whichever

dikiq vaj small

dikiq-dikiq avn just a little

dikiq-töc very few

dining nci wall of house

diri vaci stand up; berdiri

döq nci $E$ dock

dop nci custom

dop turoc-menuroc ancestral customs

dop-redop avm overcast

doq voc Father! (adoptive)

dras $^{1}$ vaj turbulent; increasing ayë dras water turbulent dras.... dras .... more .... more .... dras berlarak dras pi the more he forbad the more he went

dras $^{2}$ nci current (ocean)

dudoq vaci sit; pedudoq

dudoq berhimac sit meditating

dudoq bersila sit cross-legged

dudoq bertingok squat

dudoq bringac sit meditating

dudoq dëq api give birth; sit by fire after childbirth (see appendix)

dudoq hirik sit with legs at side

dudoq mujol sit with legs straight out

dudu nci view

duhulu avt before, former

duhulu nutu ancient times

duli nci business, concern; berduli tët berduli not concerned with

dulu see duhulu before

dumiq vaj little; see demiq 
duri nci thoms

dusa $n a b$ sin; berdusa

prangay dusa sinful habits

duthuq vact $T$ despise

duwa num two

duwa-belas num twelve

duwa-kali ave twice

duwa-puloh num twenty

duwëq nci money

suroh duwëq use money

ulol duwëq spend or dispense money

wëq-berduwëq financial success

duyok nca sea cow

E

ëh vaci defecate

ëq exc exclamation

ët $n c h$ mother

ët-apok mother and father

er ${ }^{1}$ res yes

$e^{2}$ ept emphasiser

G

gäq-giräq $n c i$ wheel

gäq-giräq lok-lok old wheel used as a

toy

gäq-giräq nipih bicycle

gäq-giräq setri wheel of car

ga.aga $n c i$ variety of edible seaweed

Other varieties of edible seaweed include:

latö, kapkrap, latoc, latö manäq

gaböq vaj deteriorated, rotten (wood)

gabus nci foam rubber

gaday vact pawn

gadik $n c i$ elephant tusk

gadoh $^{1}$ vact trouble; bergadoh

gadoh-gadoh avm troubled

gadoh-hati vaj troubled in heart

gadoh $^{2}$ vaux must, have to gagah $^{1}$ vaj essential

gagah $^{2}$ vaux must

gagiq vaci sob

gajah nca elephant

gajah mina sea elephant

gaji ${ }^{1}$ nci wages

gaji buta $n c i$ pension

gaji $^{2}$ ncilvact saw

gak-pegak avm holding

galak vact move boat on rollers

kayu galak roller

galaq vaux desire for

galik vaj unstable (of a boat)

galoq-galoq $v a j$ rising up (of big wave)

gamal nci picture, image, brand

gamën nci turmeric, an ingredient used in making betel nut for chewing and for medicinal purposes. Other ingredients are

kapoy, ubac jawa, pinang, sirëh

gamöc vact scratch (in fighting or by a cat)

gangu avm urgently, in a hurry gangu naq pi diha, tët tahu $\mathrm{He}$ is in a hurry to go somewhere, I don't know where.

ganya nci marijuana

ganyaq vaci move, remove; berganyaq

gaq vaci have room

tët gaq there's no room

garäh vact write, draw a line, strike a

match; mengaräh match

garap nci salt; bergarap

garaw vaj hoarse

gari $^{1}$ nci wrist chains, handcuffs

gari $^{2}$ see; see bergari

garöc vact scrape; mengaröc

mengaröc coconut scraper

garu vact scratch

gasaq avm vigorously, extremely

nya gasaq ikat guni $\mathrm{He}$ vigorously tied up the sack. 
gasaq menyesan very sorry

gasaq terkejuc very startled

gasat $n c i$ wide-mouthed water jar

gasi $n c h$ giant

gatan vaci itch

gati prep instead of

gatok vact suspend, hang (from above)

cawak gatok internal upright in a house

gebal nci blanket

geladaq $n c i$ roof inside deckhouse

gelagaq vaci retch

gelak nci bracelet, bangle

gelap nci kind of bark, used as caulking between lengths of kumal in Moken boats

gelaq vaci laugh; bergelaq

agah gelaq laugh at

gelaq-gelaq $a v m$ smiling

gelawaq $n c a$ spider

geli vaj ticklish

gelumak nci large waves

genäq-genäq avm unevenly (of cutting hair)

genaq vaj enough, complete

belëh tët genaq makat get not enough to eat

genaq dah That's enough

gengap vact clasp, clutch

gengëp nci eyebrows

gening nci forehead

ger $^{1} q p t$ interrogative $\mathrm{pt}$

ger $^{2} c c$ or

gerlik vact roll (an object); see grerlik

gernëq nci beads; see grernëq

getah nci sap, rubber

getik nci groove, pass between hills

gi.aq nci cymbals

gigëq vact bite

gigi $n c i$ teeth gila vaj mad

gila babi epilepsy

gilik $^{1}$ vact turn a millstone

pi gilik tepok go and mill flour

gilik $^{2}$ nci millstone

batu gilik millstone

gini so; see kaqgini

ginyëh vact brush, rub, scrub, crush (an ant underfoot)

ginyëh lumöc rub off marine growth

gipagi avt in the morning

gisäq vact play a violin

giter so; see kaqgiter

giya nci $E$ gear wheel

giyo vact $T$ reap (rice, with knife - long stalks)

graq vact arouse

grercuk vaj splashing, stirred up (of water)

grerlik vact roll (an object)

grernak nci double-ended drum

grernëq nci beads

groh nab fate

grumöng vac act as a mob

grusol vaci slip, slide off; also gusol

gudap nci coral

gugol vaci fall

guha nci cave

guläk vaci lie down

gulay nci curry

gulëng nci tinned milk

guna nci use; berguna

guni nci sack

guni kiyap cloth (used as caulking)

gunöng nci $M$ mountain

gunol nci species of marrow

gupok nci group

gupol vaj hasty, impetuous 
gurah vact excrete

guri nci earthen water jar (small-mouthed)

gurök vaci drop (of leaves, coconuts, teeth, etc.)

guru nch teacher; berguru

gusol vaci slide; see grusol

gutik $^{1}$ nci scissors

gutik $^{2}$ vact cut with scissors

gutol nci thunder

gutu nca lice

\section{H}

hä vac $T$ lead in procession

hä hatu hold funeral procession

hä prahu procession of spirit boat

ha exc exclamation

habih $^{1}$ vaci complete, cease

habih dah, ari phahadak ter the day of protection is completed

habih (ber)nyawa cease breathing (die)

tët delaq habih never finished

habih $^{2}$ avm completely

habih kelap completely dark

suka tët habih did not like at all

habih $^{3} v p t$ completed action

bungöc padi habih dah gather rice completely

habu nci ashes, dust

hac nci line (drawn or scribbled)

hacol vaj smashed

hadac nci custom, tradition, age

hadak $^{1} \mathrm{npl}$ Adang Island (Setun province)

hadak $^{2}$ vact protect against evil

phahadak, phehadak

kayët hadak white cloth worn on body

or placed over door for protection from evil

kayu hadak the wood that protects; see kayu phehadak

hadap nch Adam; also Adap

hadaq vact reach; mehadaq hagiq vact share, divide, give; berhagiq, phahagët, phahagiq

haja ${ }^{1}$ vsp pretend

haja buwac akan naq musal pretend to behave angry

haja buwac tët tahu nay maräh

Pretend you do not know master has come

haja $^{2}$ nab nature, disposition, prone to, state haja banyaq muloc tends to exaggerate haja batah disobedient

haja kira tët bajiq nature thinks no good

haja ladac me.upay nature often lies haja melaw besal tends to exaggerate haja me.upay nature deceptive haja naq jalat usiq likes to go walking haja naq semiya rajët nature industrious

haja nya sumök nature he cheats (a rogue)

haja penyegat nature lazy

hajaq vaj depressed, poverty-stricken, difficult; berhajaq, bahajaq

hajaq amac very difficult

hajaq troq real problem, real distress

berhajaq poverty-stricken

jalat itu naq bahajaq ter that path is difficult

urak hajaq poor man

yu hajaq habih until funds are used up

haji nch hadji (been to Mecca, so regarded by UL as a sami priest

halay vact give freely höy tët halay bri did not deliberately give it

halu nci pestle halu tutoq padi rice pestle

haluba vaj covetous, greedy

halus vaj fine, soft, crushed jelöq sebarak bri halus pound the goods until fine

suwara halus soft voice

halus-halus avm finely, in detail

hamac vact receive; berhamac, bahamac, mehamac

hami-kaqhami avm however it may be

hamön vaci $O$ change 
hamok avm resounding; (me)hamok

hangac vaj hot; berhangac, pehangac hangac nyawa greatly distressed hati hangac disturbed

hangös vact scorch in fire, blister hangös kena api scorched with the fire nasi hangös scorched rice

hanyä vaj fishy smell, stinking

hanyöc vaci float, drift on surface

hapa $^{1}$ avm altogether, completely hapa dëq nyawa all over the body pelaq berapi hapa caught fire, burnt completely semuha tuhat buwac bri hapa God did absolutely everything

hapa $^{2}$ ipn anything at all phakhac böh hapa together put anything at all

hapas kelamël coconut husk

hapëq vact press, squeeze, hold, clip; pehapëq

hapot maq exc $V$ swear word

harak nci charcoal

haraq vaci hope

haru vact stir

hata $c s$ because, when

hataq nci leaf roof tulak hataq sheet of leaf roofing

hati nci heart, soul, liver benasa-hati dissatisfied berhati have sorrow, anguish bersama-hati united demiq-hati sad, angry gadoh-hati disturbed, confused ikac dëq hati tie it to your heart jawoh-hati very sorry

ketuh-ketuh dëq hati sound of heart pounding

lekac dëq hati fix in your heart makat-hati hold a grudge, hate secretly masoq dëq hati understand parëq-hati repent peläq-hati astonished peli-hati joyful risaw-hati annoyed sakëq-hati jealous, at enmity sama-hati mita to ask unitedly semaq-hati annoyed senang-hati heart at rest suka-hati glad susah-hati troubled taroh-hati trust tedus-hati offended

hati bajiq happy disposition

hati beni-brani bold

hati cacaw erratic, unstable

hati hangac stirred up

hati hitap evil heart

hati kras hard-hearted

hati phal-phal overwhelmed with fear

hati tët tuhëq heart not zealous

hati tepac upright

hatu $n c h$ spirit, evil spirit, corpse bernanaq hatu protect against spirits hatu litas an evil spirit darting in front of a man

hatu rasoq possessed with a spirit hatu sitat satan tanam hatu bury a corpse

hawa npp Eve siti hawa Lady Eve (M)

hawal ${ }^{1}$ vaci spread (disease)

hawal $^{2}$ nci epidemic

hawal penyakëq epidemic

hayap nca fowl

hayap sabok fighting cock

hayok vaci walk like a drunk

he exc exclamation

helak nca eagle, hawk, kite; also lak

helöt nci,/prep front (of) mingu helöt next week

soq helöt in front, in the future

helus vact pass clear of

hempas vact throw down violently

henaq avm secretly

heng exc exclamation

hentaq vaci begin 
henus nca squid

henya nci early evening; senya

hibot vact meet, live together, stay together

hidak $n c i$ food prepared as an of fering

hidok $n c i$ nose

hidoq vaci live; berhidoq

hidoq parëq return to life

lada hidoq fresh peppers

wayak gelaq hidoq moving pictures

hijaw vaj green, blue

hilak vaci lose, disappear

hilak pi dah disappeared

hipëq vaj beside

hirat vaj astonished

hirik $^{1}$ avm sideways

dudoq hirik sit with feet to one side

hirik $^{2}$ vaci sleep on side

hitap vaj black

hiyu nca shark

hiyu besal whale

höc exc exclamation

hönda nci $E$ Honda engine

höy neg no, not, have not

höy dah it was gone

höy lalu none at all

höy sungoh definitely not

höy tët nya naq proh dah $\mathrm{He}$ will

never drive (them) away

höy tët terpakay he is worthless

ho avl there, over there

hoc exc exclamation

hoy exc exclamation

hu $a v l$ over there

hubok vact extend, lengthen; berhubok

hujat $n c i$ rain

hujat batu hail

hujat pac-prac rain sprinkling

hujat ruraq-ruraq rain (falling lightly)

hujok cape; see ujok hukop vact command, punish, have power over

bri hukop atas deniya give power over all the world

krac hukop pass judgment

urak hukop judge

hulac nca caterpillar (small), worm

hulu nci handle (of broom, etc.), pestle

hulu-balak royal messenger

hurak nca prawn, lobster

huroq vact change, exchange (money)

hutak nci debt mita naq hutak ask for a loan padap hutak settle a debt

hutat nci jungle babi hutat wild pig

huwac nci fever

huwac capaq chicken pox

huwac ketal malaria

huwac srerma cold

huwëq $n c i$ thrust a paddle outwards

huwi nci rattan, withe

huwiq exc exclamation

huwis nci smell

\section{I}

i.äk nca vulture

ijën $n c i E$ engine

ijën angën air compressor

ijën kikih dentist's drill

ijën tengaq inboard engine

ijën tuwin outboard engine

ikac vact tie (up)

ikac ler dëq hati Tie it to your heart!

nu ikac kaya dëq hati he who ties

riches to his heart

ikac padi bundle of paddy

ikat $n c a$ fish

ikat bergarap salted fish 
ikat culas kind of swordfish

ikat licët fish without scales

ikat mehumoc kind of fish

ikat pari sengac manta ray (with poisonous sting)

ikat salay smoked fish

ikat tuhol dried fish

ikat tuhoq swordfish

ikoc vac $M$ follow ikoc suka as you like

ikol $^{1}$ nci tail

ikol $^{2} \operatorname{cln}$ classifier (for animals, birds and marine life)

ilik vact shake ilik pala shake the head (negative)

imaq $n c i$ disease of testicles

ingac $v s p$ think of, reckon, consider; beringac

bri ingac remember ingac caq naq pi think (that) will go ingac naq bunöh thinks to kill ingac tët belëh can't think of it ngac-ingac concerned

ingöq vaci shake; beringöq

ingöq-bringöq vact shake, wave (something to and fro)

ini $^{1} d p t / d p n$ this taq dëq ini from now

ini $^{2} \operatorname{cs}$ now ini paq pi dah Now father has gone. inok nca principle, mother (of animal), germ

inyang $n c h$ great-grandparent

ipak nci lobster-spear (two-pronged)

ipay vaj in-law (of brother or sister)

irëq vact tow, lead

urak irëq cawbaw man who leads the groom at wedding

iriq vact sluice

isäk vact move (something a little distance)

isäk dikiq move along (as in a bus) isak $n c i$ gills

isak berdarah $V$ female genitals

isak ka.u $\mathrm{npl}$ Sangkao village, Lanta Island

isaq vact smoke, suck; me.isaq, pi.isaq isaq ayë asap drink orange juice

isëq $n c i V$ female genitals

isët vaci be furious

isi $n c i$ contents, nature, inner meaning; berisi

isuc vact erase, rub on isuc tët trerbëq cannot rub out isuc ubac apply ointment

isuc mukha wipe the face

itali $n p l$ Italy

itat $n c i$ diamonds

it.erri $n p l$ Italy

iti $n c i$ filling, topping (in cakes, etc.)

itiq nca duck

itiq jawa goose

itiq rasa goose

itök vaci meditate

itu dpt/dpn that itu ler that's it!

itu pot even that

iya $v o c$ little girl

\section{J}

jäq-bejäq avt evening

jabac vact clasp (hand)

jadi $^{1} v c o p$ be, become; berjadi

ber jadi makes, creates

jadi $^{2}$ vaux happen

jadi $^{3} c c$ and so

jadi-caq $c c$ means that

jadi dah That's enough!

jaga vact guard

jahac vaj evil 
jahanam nab danger, perishing macap naq jahanam dangerous

jahëq vact sew; (me)nyahëq

jahul vaci blaze up

jajac nci example

jakal $n c i$ roots

jakok nci com

jal-lajal vaj sloping

jala $^{1}$ vact lower into water, fish with net;

(me)nyala, (pe)nyala

jala $^{2}$ nci casting net

penyala casting net

semiya penyala net fisherman

jalak nch prostitute

jalat ${ }^{1}$ vaci walk, travel; berjalat

jalat $^{2}$ nci road, path

jamat nci bridge, wharf

jamöng nci torch (made of bamboo or coconut fronds)

jamöng suloh ikat torch to attract fish

jamu nci cashew nut

jamu burok nci type of fruit

jamu kelik nci guava

jana vaj widowed

kilaki jana widower

nibini jana widow

jangan ${ }^{1}$ res do not

jangan naq... don't ... (mild)

jangan $^{2}$ prep with, and jangan ... jangan ... both ... and ...

jangöng vaci rock, see-saw

jangoc $n c i$ beard

janu nci opium

janyi vsp promise; berjanyi

jap nci plate, clock, hour

jap tangan wristwatch

jarak vaj infrequent, far apart

jari nci finger; berjari

jakon (ber)jari pronged hoe jari kaki toe

jarop nci needle

jawa nci tamarind

jawoh vaj distant

jawoh-hati dismayed

jawoh jangan far from

jawol vaj arched

jekan nci span

jelik vaci look askance, look away from

jelöq vact pound (curry ingredients, etc.); penyelöq

(daw)penyelöq stone mortar

jeluk vact poke eye

jema nca mite found under nesting hen

jemöl vact dry, expose

jemöl angën dry in the wind

jemöl ari dry in the sun

jemu $v a j$ bored, tired of, saturated

jenäh nci kind

jenäh-jenäh various

jenah $^{1}$ vact conquer

jenah $^{2}$ vaux in the habit of (doing something not approved)

amët jenah refuse to give up or give in

jengöq vact peer at, look at, visit;

(me)nyengöq

jepuc vact snatch away

jeray $n p l$ Mt. Jerai (near Penang)

jerikan vaj curly (of hair)

jerlepök vaci sleep face down

jernäh vaj clear(water)

jetiq vact flick finger against thumb

jilac vact lick

jirac nci cemetery

joc nci $E$ jute; also jut

joh res Come! okay (implies speaker will participate)

jok-jok vaci stumble forward 
jrermak vact cross over (river, etc.)

juga avm too, also

juju-caq $c s$ as if

jukök nci boat (short and wide-beamed,

e.g. Buginese ship)

julok vact gather, pick (fruit with container

on end of long pole)

juloq vact clean the ear (with feather or tool)

junyok vact lift, carry, hold (above head)

jurus avt presently

jut $n c i E$ jute; also joc

jutö vaj destined (marriage parmer)

juwan vact sell

\section{$\mathbf{K}$}

käkëp $n c i T$ torch

käq-lagi $a v t$ in a moment

käq-ukäq $a v m$ uneven

käqkäq $n c i$ fan, propellor

kabök nca kind of shellfish

kaboc $n c i$ fog, mist

kabol lawoc kind of shrub

kabu nci kapok

kaca nci phial, jar

kacak nci bean, nut

kacak cepac frilly bean

kacak panyak long bean minyaq kacak bean oil

kacaq vact tread on, stamp on

kacik vact nail kacik tikaq bolt the window

kaciq vact cut (betel nut), grind (teeth); pengaciq

kadak see dak-kadak sometimes

kaka $n c h$ older sibling

kaki $n c i$ foot

kala $^{1}$ cs whenever, if kala $^{2}$ av $q$ when?

kalan $n p l$ village name

kalap $n c i$ pencil

kalaw $\operatorname{cs} M$ if

kalëh vaci turn; also alëh, beralëh

kalëk vact carry at side (arm bent)

kali $^{1}$ avt times (in compounds) berkali sometimes duwa kali twice sekali once

kali $^{2}$ vac dig

kamëk nca sheep

kami ppn we (excl.)

kana rusa nci medicinal plant

kanak nci enclosure

kanal vact carry on a pole menganal a load (amount carried on one pole)

kanan nci right side

kanok $^{1}$ vact carry in a fold, pregnant menganok conceive

kanok $^{2}$ nci fold of cloth at waist

kantukan nci pumpkin

kanyaw ppn you (pl)

kapä vaj flat, empty, collapsed, paralysed

kapan $n c i$ ship

kapan cekaq dredge, grab style

kapan trerbak aeroplane

kapaq $n c i$ axe

kapas nci cottonwool

kapkrap $n c i$ seaweed that floats

kapol nci lime

kapol mirah lime (used with betel nut)

kaptat nch $E$ captain

kapus vact shut, close

$\mathrm{kaq}^{1}$ ppt to

lihac kaq duwëq think only of money nya timaw jadi kaq semiya duhulu he feared to be like the olden men 
plihac kaq kami revealed to us, seen by us

serupa kaq similar to

kaq ... $\mathbf{k a q}_{\text {... }}$ either ... or ...

$\mathbf{k a q}^{2} c s$ if

serupa kaq as if

kaqbik $n c l$ classifier for lengths of wood

kaqgini $^{1} c c$ so

kaqgini $^{2}$ avm like this

kaqgiter $^{1} c c$ so, then

kaqgiter $^{2}$ avm like that

kaqhami ${ }^{1}$ avq how?

kaqhami $^{2}$ avm in whatever way

hami-kaqhami however it may be

kaqpada prep $M$ to

karac nci rust; berkarac

karah nca hawksbill turtle

karak nci reef

karap vaci capsize, turn over (boat or 4wheeled vehicle)

karok nci sack, sack-like bag

kasal vaj rough, coarse

kasëh vact love illicitly, commit adultery

kasi vact castrate

kata $v s p M$ speak

katäq vact carry (underarm)

katak vact prohibit, restrain, forbid

katëh nci trigger

kathäk vaj pregnant (animal); berkathäk

katöq vact hit; (me)ngatöq

ka.u nca kind of fish

kaw ppn you (sg)

kawat $n c h$ friend, group of; berkawatkawat swarming

kawat belëh bersama bajiq a close friend

kawat burok flock of birds

kaw.i nci $T$ chair; also kö.i

kawoc vact scoop up kaya $v a j$ rich

kayën nci fishing line; mengayën

kayëq vact hook (with fishhook, etc.)

kayët nci cloth, clothes

kayët berlubak sarong

kayët ketak curtain

kayët mengetak curtain

kayët pöc-pöc cloth wrapped round baby

kayoh vact paddle; (me)ngayoh, pengayoh

kayu nci wood, tree

puhot kayu tree

tukak kayu carpenter

kayu api firewood

kayu phehadak wood of protection (wooden crosses planted on the beach to protect the village)

kayu plitak cross, crucifix

kayu riyok kind of reed

kebah vaci (fever) abates

kebaq vaj bathed in perspiration

kebas vaj numb, stiff

kebik $c$ ln classifier for sheets of rubber, etc. and planks of wood

kebok nci ridge

kebot $n c i$ garden

kebuk vaj bulging, puffed up

kebusäq vaj constipated

kecac vact plug, patch temporarily

kecap npl Jum Island, Krabi

kecay vact scatter cay-baday scattered widely

kecubuk nci crown

kedah $\mathrm{npl}$ Malay state of Kedah

keday nci shop

kedemay nci Lord Buddha

keduman nci compass

kedumaq $n c i$ Thai drum 
kedunot nci olive

keduwa num pair, second

kejaq vaj firm, rigid

kejawaq nca monitor lizard

kejawaq kret black monitor lizard

kelac $n c i$ sheet (of sailing boat)

kelacuq $n a b$ confusion, turmoil

keladi $n p l$ island south of Surin Island

kelagi $a v t$ in a moment; see käqlagi

kelamël $n c i$ coconut puhot kelamël coconut tree sapuc kelamël coconut husks

kelamël hijaw green coconut

kelamël masaq hitap ripe coconut

kelamël muda young coconut

kelamël mumak smaller young coconut (water but no flesh)

kelap $n c i$ darkness

kelawal $n c a$ bats (small)

kelekaq $n c i$ things, ingredients

kelekaq dalap internal organs

kelekaq nu ba.u sweetsmelling spices

kelik nch Tamil

kelilik $^{1}$ avl around

kelilik $^{2}$ prep round

kelimac vact save, use sparingly, preserve

kelinöng avm sheltering

kelubak nci kind of tree

kelubi $n c i$ kind of plant; see asap kelubi

kelukuy $n c i$ kind of tree

kemak $^{1}$ vaci blossom; (me)ngemak

kemak $^{2}$ nci puffed rice

kemal nch twins

kemari avt yesterday

kemari isa day before yesterday kemas vaj secure

ikac bri kemas tie up securely permelaw kemas sure word

kemas-kemas avm securely

kemat ${ }^{1}$ vact fold the arms

kemat $^{2}$ avm pressed together

kemëh vact urinate

kemën vaj still, motionless, quiet

kemën-kemën $a v m$ quietly

kemenan nch Thai headman

kemiyan $n c i$ benzoin incense

kemön nch nephew, niece

kemön anaq descendants

kemöq nci bubbles, froth

kemöq ayë nci sponge

kemok vaj swollen, distended

kemubok nci roof

kemudi nci rudder, helm pegak kemudi hold the helm

kemuk vaj stopped up, constipated

kemulu nch $O$ village leader

kemuru vaj jealous

kemus vaj holed (of plank, etc.)

kemuwak nci pandanus palm frond

kemuwang nci cloud

kena $^{1}$ vact touch, experience

kena dah That's correct

kena $^{2}$ vaux must

kening $n c i$ forehead

kenira nci flag

kenuri nci spirit feast

kenuri prahu feast eaten in boat (see appendix)

kenyang vaj satisfied

kenyiq nci gums (in mouth)

kepäw $v s p$ shout out (so as to frighten)

kepala $n c i$ head, leader; see pala 
kepan vac clench fist

keparok nca skink

kepiq vact squeeze, grasp, massage, oppress

kepiyah $n c h$ hadji's white headdress

kepuh vac blow spirit away

kerban vact $M$ sacrifice (Muslim word)

kerbaw nca water buffalo; see krerbaw

kerbelakak vac betray

kerbelol vact starving; belol

kerbetol vact teasing, playing about; betol nya usiq kerbetol, nya me.upay kaqgiter he was teasing playfully, he was deceiving like that

kerbi $n p l$ Krabi town; see krerbi

kercac vaj crowded; see krercac

kerja vac/nab work; see krerja

kerlebëh $n a b$ transgression semiya buwac kerlebëh transgressor

kerlok nca kind of spirit

kermëh vaci urinate

kermös vaj dirty; see krermös

kernäq nci dots, dashes

kernam nca rabbit; see krernam

kertäq ave almost (strike, fall, etc.); see krertäq

kertas $n c i$ paper; see krertas

kertoc vaci pass wind

ketäq ${ }^{1} n c i$ spray-screen

ketäq $^{2}$ nci armpit

ketac vact pull, extract; (me)ngetac, terngetac

mengetac having an epileptic fit

terngetac convulsed

ketak $^{1}$ nci screen

ketak $^{2}$ vact block

ketal vac shake, tremble huwac ketal malaria

ketap $^{1}$ nca crab ketap $^{2}$ vact plane (wood)

ketap $^{3}$ vact reap; ngetap

ketaq vact overtake melaw tët ketaq habih not finished speaking nya pi tët ketaq He didn't go in time.

ketawaq $n c i$ gong

kethäl vaj vibrating, distorted (sound)

kethöq vact knock, pound (with knuckles)

ketibac nca tick

ketika $n c i$ auspicious time

ketöc nci food scraps

ketoc vaci pass wind

keton $^{1}$ nci lump

keton $^{2} c \ln$ classifier for lumps

keton-keton avm billowing (clouds of smoke)

ketuh-ketuh avm $O n$ heart beating irregularly

ketuha nch elder

keyaq vaj teeth strong

khäq vact choke on a fishbone

khac see phakhac together

khanaq ${ }^{1} v s p$ purpose; berkhanaq lagu berkhanaq needs, wants

khanaq $^{2}$ vaux intend to

khön have food stuck in throat

khröq $n a b T$ fate bumöl lihac khröq shaman

khru $n c h T$ teacher

ki.as vact mock melaw ki.as speak in a proverb

kicöh vact swindle

kikay vact scratch, sweep mengikay, pengikay pengikay broom, rake

kikih vact scrape

kilac nci lightning

kilaki nch man, male 
kilaki jana widower

kilang $n c i$ dredge

kilas $n c i$ windlass; (me)ngilas mengilas haul in (with a windlass)

kilo nci kilogramme

kimaq exc $V$ curse

kipaq $n c i$ place where wood splintered

kipas vac sweep away, refuse, brush off pengipas broom, fan, propeller

kira $v s p$ think, reckon; berkira temus kira think through to a decision

kira-kira prep about

kiri $n c i$ left side

kirip vact entrust

kirip dëq entrust to

kita ppn we (incl)

kiwëq vaj crooked, aslant

kiyak nca small deer (with small horns)

kiyat avl here

kiyuh avl there

klakhëk nca hornbill

kö.i nci chair

köq-kräq nci dice

köq-kröq vaj On breakable (bamboo, wood), crunchy

ko nci $E$ goal (in football)

kok nci ribs of boat

kopi $n c i$ coffee

koq $^{1}$ nci yoke, bow, arch

$\mathbf{k o q}^{2} d p t i$ the (often indicating plurality) koq kepala kira group of headmen koq kiqdikiq just a little (rice, water, money); dikiq

koq-crerkoq avm upturned

kroh vaj brackish, murky

kra nca long-tailed monkey; see also broq short-tailed monkey; maqwa gibbon

krabu nci Thai salad krac $^{1}$ vac cut off; berkrac, terkrac

krac hukop pass judgment

krac kulëq suläw circumcise

krac $^{2}$ cln piece (cloth, etc.)

krachak nca barnacle

krala $v s p$ recognise; berkrala

kramac nci sacred shrine, spirit of shrine (see appendix)

krana $c s$ because, for the purpose of

krana ini therefore

krana itu therefore

krani $n$ ch $M$ clerk

kranyak nci crate

kraq vact stick together; berkraq

kras vaj hard, powerful hati kras persistent hukop kras severe punishment melaw kras speak authoritatively

kras-hati obstinate

krat $n c i$ fireplace ruwak krat kitchen

kraway nca octopus

krerbaw $n c a$ water buffalo

krerbi $n p l$ Krabi

krercac vaj crowded; berkrercac

krerja vac/nab work; berkrerja

krermös vaj dirty; terkrermös

krerna $c s$ because, for the purpose of; see krana

krernam nca rabbit

krertäq ave almost (fall)

krertas nci paper

krertas rupëq sandpaper

krih nci kris

krik vaj dry (land); terkrik ayë krik low tide berkrik beach a vessel terkrik dah stranded

krita-api $n c i$ railway 
kröt vac twine around, embrace; berkröt

\section{ku ppn I}

kubak nci lake, pond

kucay vact bother

kuci $n c i$ lock anaq kuci key

kuda nca horse

kudën nci scabies; berkudën

kudën buta itchy skin disease

kudok vaj maimed, amputee

kukol vact shave

kuku nci nail, claw

kulëq $n c i$ skin (of animal), fruit peel

kuli $n c h C$ labourer, sailor

kumal nci zalacca palm, light wood used for Moken kabangs and U.L. spirit boat asap kumal kind of fruit prahu kumal boat made of zalacca palm

kumul vact gargle

kuning vaj yellow

kunya $p p n$ they (not neuter)

kunyäq nci cummin bras kunyäq yellow rice; significant in some spirit ceremonies; see bras and asan.

kunyëm vaci smile

kupi coffee; see kopi

kura nca turtle (land)

kurak $^{1}$ ave few

kurak $^{2}$ vaci lessen

kuraq $n c i$ scaly skin disease

kurus vaj lean, thin

kusoc vaj tangled

kutëq vact collect (taxes, small items)

kutök $^{1}$ vact cut into sections

kutök $^{2} \operatorname{cln}$ classifier (for lengths of wood, pipes, etc.) kuwasa vact try to, attempt to nya berkuwasa sungoh $\mathrm{He}$ tried with all his might.

$\mathbf{L}$

läh ave only, just läh sa only one läh sekali only once

läq ${ }^{1}$ vac flash

läq ${ }^{2}$ exc $T$ emphatic

läw-läw nca shell, shellfish (small kind, found on beach)

labat vact touch shoulder, embrace neck jalat labat to walk together with arms around each other's necks

lac $v a c A b$ see; lihac

lac-lac vac looking; lihac

lachal vact slide

lada nci peppers

lada hidoq fresh peppers

lada mati dried peppers

lada tuhol dried peppers

ladac vaux habitually, by practice or nature nibini ladac woman with compulsive behaviour pattern nya ladac makat nasi tengah ari $\mathrm{He}$ is in the habit of eating rice in the middle of the day

ladan $n p l$ Saladan village, Lanta Island

ladok $^{1}$ vact collide, strike (e.g. boat on rocks)

ladok $^{2}$ nci large weight (used with nets and fish traps)

la.ël vaj slimy; berla.ël

lagala nci compound used as caulking

lagi ${ }^{1} c c$ also

lagi $^{2}$ avm at all, again, also, still

mudah lagi easier

payah lagi harder

lagi-lagi avt again 
lagu nci story, subject, ceremony lagu serupa masoq selap circumcision (polite)

lah ept $M$ emphasiser

lahöq ${ }^{1}$ nci dimples

lahöq ${ }^{2}$ vaj dented, sunken, depressed (as in oedema)

lahok nci kind of shrub with large leaves

lahtala nci $M$ God (Muslim)

lajaq vac move fast (of a boat, vehicle or man)

jalat tegal urac lajaq nya ter $\mathrm{He}$ is a strong walker, he walks fast.

lak nca hawk, eagle, kite lak jawa (white) Javanese kite lak pi.api (reddish) Brahmin kite

lak-ngatöc $n p l$ village on Jum Island

lakah $^{1}$ nci step

lakah $^{2}$ vac step over; melakah tuhoq lakah stretch out a pace (e.g. baby leaming to walk)

lakah-lakah vaj abbreviated

lakgelak nca millipede

laki nch husband

laki-ayë nca dragonfly

laki-bini nch married couple

lalak nci lalang grass

lalu1 vact pass by; selalu, terlalu

lalu $^{2} c s$ then

lalu $^{3}$ ave at all

höy lalu none at all

lalu ${ }^{4}$ vaux proceeded to

lama avt long, former (time)

lama-lama ave for a long time

lamac vaj slow

lamac-lamac avm slowly

lamal $c \ln$ classifier (for leaves and pieces of paper or cloth)

laman nci area around a house

lamay vact beckon (towards or away) lamok vaci soar, go far (of a sound); melamok

lamula $^{1}$ vaj first, original

lamula $^{2} a v t$ originally lamula nutu in the very beginning lamula ter in the beginning

lamung vact throw upwards

lanaq nca porcupine, hedgehog

langä vac wash hair agal langä vine used for washing hair langä pala wash the head

langäq nci sky, heaven

langal vact hit, collide langal batu hit a rock

langal karak hit a reef at low tide

langaw nca housefly

langela nca scorpion

langoh vact look up

lapal vaj hungry

lapal nasi hungry for rice

lapat num eight

lapat-belas eighteen

lapat-puloh eighty

lapih' ${ }^{1} n c i$ layer, deck (in a ship)

lapih $^{2} c \ln$ classifier (for objects in layers)

lapoh nci long robe

laqäw $n p l$ Hey Island, near Phuket

laqulaq $n c a$ bats (large)

larak $v s p$ forbid; berlarak

lari vaci run; berlari

berluma berlari run in a race

semiya lari fugitive

latah vaj ticklish

latap vact trample on, stamp on

latay nci floor, deck (of split bamboo) apal latay lay a slat floor

lathaq ${ }^{1} \mathrm{npl}$ Surin Island

lathaq $^{2}$ vact drive a pile

latöy nci rock seaweed 
lawat vact endure, oppose, fight against; berlawat

lawoc $n c i$ sea buwak kaq lawoc spirit offering thrown out to sea to heal a sick person kabu lawoc kind of shrub lumöh lawoc "Sea People", the "Urak Lawoi"'

lawoq $n c i$ cooked food eaten with rice (usually fish)

layal vaci sail; berlayal kayët layal sail (of a boat)

layal hatu rainbow

layol vact singe, warm with flame

layu vaci shrivel

layu tuhol dried up; see krik dry land

lëh-belëh $a v m$ as much as possible

lebac vaj plentiful, abundant, productive

lebay $n$ ch Muslim imam (lower status than hadji)

lebëh ave more, greater; melebëh lebëh dëq kawat more than others lebëh dëq makat, lebëh dëq suroh enough to eat and use naq lebëh wants to excel nasi lebëh left-over rice

lecah vaj muddy (ground)

lega vaj wide, broad, improving (health), healed ada lega dikiq dah a little better

legeta nci noggin, small cross timber

lejak vac reach out (the hand)

lekac ${ }^{1}$ vact kindle; plekac

lekac ${ }^{2}$ vact attached to, addicted to taroh lekac dëq hati be convinced of lekac dëq lihël fishbone stuck in throat

lekac araq addicted to alcohol

lekac ganya addicted to marijuana

lekac janu addicted to opium

lekap vact break, snap (a rigid or brittle object) lekuq vaj bruised barah lekuq swollen and bruised

lemah vaj soft, weak

lemah-hati vaj soft hearted

lemah-lemah vaj soft and spongy

lemaq vaj fat, succulent

lemas vaci sink

lemas mati drown

lemu nca cow ayë lemu incantation, magic art buwac-berbuwac ayë lemu keep making incantations

lengäq vaci vanish, disappear

lengan $n c i$ arm (shoulder to wrist)

lepa vact forget oneself, ignore, be unaware of nya lepa nyawa taqasik he forgets himself (as someone presuming upon another)

lepäq vact break into pieces (soft object)

lepac nci sleeping mat

lepah vact collapse, fall down

lepas $^{1}$ vac free, delivered; melepas, plepas

lagu lepas freedom

lepas dah Delivered! (of a baby)

lepas dëq freed from

lepas ${ }^{2}$ prep after banyaq tahot lepas maräh dah after many years had passed lepas itu after that

ler $e p t$ emphatic particle

lesok nci mortar (wooden, for pounding rice)

lesok batu penyelöq stone mortar (for making curry, etc.)

letak vaci lay down (face upward); terletak

letëh $v a j$ weak, worn out, weary

letoq $n c i$ blister

li.ang $n c i T$ feast makat li.ang have a feast 
libal vaj wide (of goods, boat, etc.)

libuli $n c i$ bottle

licët vaj slippery, smooth

lidah nci tongue lidah tegal slow to leam

ligac vact turn

ligac mata dizzy

lihac vact look at, see; lac, melihac, plihac

bri lihac show

bumöl lihac kröq shaman

lac see

lac-lac looking

lihac kaq duwëq covetous

lihac ketika use enchantments

plihac reveal, manifest

lihac-lihac vact watch out

lihël $n c i$ neck

likal vact twist, coil together

likök-likök avm zigzag

liköq vaci turn, swerve

likoq vact wind (rope, cloth, etc.)

lima num five

limaw nci citrus fruit

asap limaw hurak pomelo

asap limaw manëh orange

asap limaw nipih limes

limaw nachuq limes

lina vaci sleep

lingak vac roll (of a boat); rinse (articles)

linöng vaci shelter, hide

nöng-klinöng in hiding

linöng angën protected from the wind

linoh $n c i$ shade, shelter

lipa $n c i$ internal organ

lipac vact fold

lipal vact throw, toss

lipas $n c a$ insect

lipas kelik cockroach

lipat $n c a$ centipede

lirah nca locality lisoh vaci pant, gasp

litah nca leech

litah bahaya kind of sea horse

litas vact pass by quickly, dash past; melitas

liya $n c i$ ginger

liyac vaj sticky (ground, rice, curry, etc.)

liyak $n c i$ wound, sore

liyal vaj wild, untamed

liyol $n c i$ spittle ayë liyol spittle

lökbelök vaj growing bigger (child, animal, etc.)

löklihac vact test, try out

löl nci harpoon

lömong nci large pond (as tin mine pool)

lötëng nci $C$ upper storey

lobong nci Moken spirit shrine (usually a carved square pole)

lok-lok $n c i$ improvised wheeled toy gäq-giräq lok-lok old wheel used as a toy

lubak $n c i$ hole, grave

lubak jarop eye of a needle

lubak kumak nci drain hole (in ribs of boat)

lubak möngmöng bunghole of a boat

lubak pahëq exhaust pipe of steam engine

lubak pusac prahu hole for draining boat

lubaq pahëq bitter leafy vegetable

lubuq para $\mathrm{npl}$ village on Lanta Island

lucuh vaj tapered

luka $n c i$ wound

lukak $n c i$ hull

lulu $n c i$ flesh, meat

lulu asu "dog's meat", calf of leg

lumac vaj very fine, very small jelöq bri lumac pound until crushed 
lumöc nci marine growth ginyëq lumöc rub marine growth off boat's hull

\section{lumöh ipn group}

lumol vact wipe on

lunak nci lake lunak api lake of fire

lunas nci keel of boat

lungoq $n c i$ heap, pile lungoq api fire heap

lupa vact forget

lupac vaci jump; melupac

lupaq $n c i$ shallow hole jalat berlupaq road holed

lupol vaj muddy

lurök nci channel of water (on beach), five minutes of time tiga lurök three intervals on a watch $=$ 15 minutes

lutoc nci knee tuku lutoc kneel

lutoq $n c i$ water blisters; see letoq

luwak $v a j T$ government

luwal $n c i$ outside luwal baksa foreign

luwaq nci strait

\section{M}

mäng-ngemäng $v s p$ ask from each other ma $n c h$ uncle (younger brother of parent); see wa

mabok $\mathrm{npl}$ Yao Island (Phangnga province)

mabok besal Big Yao Island

mabok demiq Small Yao Island

maboq vaj drunken, poisoned (by mouth)

maboq araq drunk with spirits

maboq kapan seasick

maboq setri carsick

macal $n c i$ perspiration macap nci kind, species

macap bekaq just like

macap naq almost

macap naq mati dangerous

macap-macap different kinds

mahan vaj expensive

mahpagi nci tomorrow

mahpagi isa day after tomorrow

makan vact caulk a boat

makat vact eat

barak makat food

bermakat to give food to

hatu makat nanaq child dies as a result of sorcery

kapan makat ayë ship draws water pemakat food makat li.ang feast

makat upah work for wages

makay vact use (in a bad sense)

makay ayë lemu use witchcraft for sick person

makay hatu use an evil spirit (sorcery) urak makay sorcerer (malevolent)

maki vact curse

makoq nci bowl

maläq vaj mean, stingy

malap nci night malap senya last night soq malap at night

malaw $n c i$ beeswax, sealing wax

maloma nca porpoise

malu $v s p$ curse

mamöng nca large kind of fish

mamon vaci talk or walk in sleep

manay $n a b$ idea

nya buwac manay taqasik, nya

buwac kerlebëh He did according to his own thoughts. He exceeded (instructions).

nya manay bri kaq kawat bukat barak taqasik $\mathrm{He}$ of himself gave it to his friend, not his own goods (something of importance belonging to someone else).

manay sediri by own cleverness 
manay taqasik follow own choice

manëh vaj sweet

bemanëh sweet potato

mani vaci bathe

manoq vact forge through undergrowth; ranoq

manyac nci $M$ corpse

manyak-röc avt for ever

melaw manyak-röc speaks ceaselessly

maq $n c h$ mother

maq dëq ku my mother

maq metuha mother-in-law

maqah nab $M$ pardon

maqalac nci uniform, bridal costume, special dress (of royalty)

maqpaq mother and father

maqplap nci mango

maqwa nca gibbon; see kra

maräh vaci come; bermaräh, mëh( $A b)$

bermaräh to bring with

besal maräh grow big

jadi maräh happened

taqdëq itu maräh since then

marama nca butterfly

mari vaci $M$ come

mas nci gold

masa $c s$ when

masap vaj bitter

masaq vaj cooked, ripe

bermasaq ripen, cook, dry out

masët vaj brackish, salty

masoq vact enter

masoq dëq hati understand

masoq selap enter Islam, be circumcised

mata nci eye

ayë mata tears

mata mirah eyes red (through

intoxication)

semata single-minded, wholehearted

tamata policeman mata ayë spring (of water)

mata.ari nci sun

atas mata.ari east

bawah mata.ari west

ruwak atas mata.ari front room (facing east)

matah vaj half-cooked, unripe

matang nci S.S.Matang (formerly on regular run from Penang to Phuket and Rangoon)

mathu nca bee

mati vaci die ayë mati 'dead water' (neap tides)

lada mati dried peppers

mawa vact call a witch doctor; bermawa

mawös vact spring out of water. (Many speakers give the last syllable strong nasalisation).

ayë mawös water from a spring

may nch aunt (younger sister of parent; see wa)

mëh $A b$ see maräh come

me.ajaq vact provoke, tease (by touching); ajaq

mebelëh vact gets; belëh

medaq $n c i$ semi-cooked rice

medoq vact place in ship or boat; pedoq

megah vaj powerful, invulnerable

megak vact hold, drive (vehicle or boat); pegak

megali nch Sikhs, Punjabis (night watchmen)

mehadaq vaci approach

mehamac $^{1}$ vact receives, welcomes; hamac

mehamac $^{2}$ nch mankind-only in umacmehamac

mehamok vaci resound; hamok

me.isaq ${ }^{1}$ vact smokes (tobacco)

me.isaq ${ }^{2}$ nci cigarette (factory made)

mejadi $v$ cop becomes; jadi 
mejaga vact guards, watches over mejah $v s p$ criticise, rebuke melagöt vact pitch (of a ship)

melakah vaci steps out melamok vaci soar, carry far; lamok melatik vact throw out, throw away melaw $v s p$ speak bermelaw bermelaw make a speech permelaw word permelaw kemas sure word melaw kipas deny, refuse melaw panaq-panaq abbreviate melaw sikac speak briefly melaya $n p l$ Malaya; also melayu melayak vact float, fly melayu $\mathrm{npl}$ Malaya; also melaya melebëh vac exceed; lebëh melengung avm perplexed melepas vac free, give birth to; lepas meli vac buy; beli Occurs only in ari meli the third day of the pelacak spirit festival

meli.aw ${ }^{1}$ vaj infected

meli.aw ${ }^{2}$ vact $T$ turn aside

melihac vact sees

melitak vact steer parallel to waves, reach melitas vact pass, cut across path of melupac vaci leaps memawa vact summon (a witch doctor) memela $v s p$ murmur, complain memuköq vaci crow (of a cock); muköq menakoc vaci fears; takoc menangäh vaci cries; nangäh menangäh raquq cry together menanya $v s p$ asks, enquires; tanya menari vaci dances menatak see benatak animal menataq vact consider menati vact waits; nati menatu nch son-in-law, daughter-in-law meneloq vaci follow a roundabout course menga $v s p$ greet mengacik nci button; also pengacik mengaciq $n c i$ cutters (for betel nut) menganok vact conceive; kanok mengaräh nci match; garäh mengaröc nci coconut scraper; garöc mengasaq $v a c$ stick to (body); gasaq mengasaq daki dirt sticking to body mengasaq sabot soap sticking to body mengatöq vac hit, crack open; katöq mengatoq vac sleepy; ngatoq mengayën $v a c$ fish with a line; kayën mengayoh nci paddle; also kayoh, penganyoh

mengëp vac chew betel nut; ngëp

mengelaq vact avoid

mengelok vaci sleep in late; ngelok mengetën vact nibble (fish) mengikay vact sweep mengilas vac haul in (with a windlass); kilas

mengukol vact shave; kukol

mengutëq vact collect, gather (money, small items); kutëq

menidas vact pass (going in opposite direction)

menidëh vaj boiling

menikah vact marries

menilëh vaci seep out, flow out; nilëh meningan vac $O$ die; tingan meningay vact listens, obeys; dengal, ningay

meniyac vaci carry out a vow menulëh vact writes; tulëh 
menulok vact help; tulok

menunoq $v a c$ bow down to; tunoq

menunyoq $v s p$ boast; tunyoq

menupak vact stay or travel with, be possessed with evil spirit; tupak

takoc ada menupak ter afraid you have an evil spirit

menutoq vact pound (rice); tutoq

menuwa see benuwa world

menyaga vact observe, obey

menyahëq vact sews; jahëq

menyala vaci blazes; nyala

menyangah vact pitch, go against waves

menyanyi vac sings; nyanyi

menyarëq $v s p$ tells; carëq

menyari vact seeks; sari

menyawa vaci breathes; nyawa

menyawa besal sigh

menyawa sepuc-sepuc gasping for breath

menyegat vaj lazy; segat

menyekaq vact fish (with big hook)

menyelap vaci dives; selap, nyelap

menyemah vact worships; semah

menyengöq vact looks at, visits; jengöq

menyesan $v s p$ feels sorry for; sesan

menyukën vact scrapes out; cukën

menyuri vact steals; curi

menyuroh $v s p$ commands; suroh

me.oc vact praise, flatter

mepök vaci decamp (temporarily, after argument)

meraba vact grope

merakaq vaci creep, crawl

merap vact hatch

meraq nca peacock

merayu vaci groan

merigaq vact catches meriyap $n p l$ island near Surin Island

meriyan vaci purr, growl

merka nci seal; see mrerka

merpu $n p l$ Crab Island; see mrerpu

mesat vac commands; pesat

mesing vact dredge

mesiya nch $O$ mankind; see semiya umac-mesiya mankind

mesoq vact observe, spy urak mesoq spy, informer

metat vact arrange, adorn

metuha nch in-law maq metuha mother-in-law paq metuha father-in-law

metul vact tease playfully

me.ugas vact lever off

me.upay vac lie, deceive

mi.aw nca cat

milëh vaci pregnant

mina see gajah mina sea elephant

minëq $n c i E$ minute

mingu $n c i$ week ari mingu Sunday

minyap vact borrow bri minyap lend

minyaq $n c i$ oil

miq voc younger sibling

miqdemiq ipn small amount (cloth); demiq

mirah vaj red

misay nci moustache

misël $c s$ even though

misël-caq even if

mita $v s p$ ask for, request

maräh mita come and ask (engagement)

mita naq hutak ask for a loan

sama hati mita unitedly ask

miya vact look for (something or someone) 
möhun nci cigarette (factory made)

me.isaq möhun smoke a cigarette

mökën nci Moken tribe

möngmöng nci bunghole

moq nci hat

mot nci dew

mrerka nci seal, mark of rank

mrerpu npl Crab Island

muda vaj young, light in colour urak muda young people from 12-15 up

mudah vajlavm easy, easily mudah lagi easier

mudah berlawat quarrelsome, argumentative

muji vact praise; puji

mujoq vact comfort, relieve; pujoq

mukac vac fish with a net; pukac

mukal avt early dawn

mukha $n c i$ face

bri mukha kaq show respect to

muköq vaci crow (of a cock); memuköq

mula $n c i$ beginning

mula-mula avt in the beginning

muloc nci mouth, voice

haja banyac muloc lit. 'nature many mouths', i.e. tends to speak too much, to exaggerate

meningay muloc bini listens to wife's voice, i.e. henpecked

munën nci piano, organ

mungay $n c i$ edible tree bean

mungöc vact collect, gather; pungöc

munyang $n c h$ great-great-grandparent

murah vaj cheap

murëq $n c h$ disciple

musal vaj angry

musal-musal avm at enmity

musët $n c i$ season

musët-musët avt forever mutuboc nci $E$ motorboat

\section{$\mathbf{N}$}

nähsa only one; see läh

nabi $n c h M$ prophet

nabi musa $M$ prophet Moses

nabi noh $M$ prophet Noah

nachuq $n c i$ chilli sauce; limaw nachuq limes

nachuq renak fried chilli sauce

naga nca serpent

nakaq $n c i T$ diving mask, engine cover

nam num six

nama ${ }^{1}$ nci name; bernama

nama ${ }^{2}$ qpn what? why?

buwac nama why?

nama $^{3}$ ipn what, anything

höy nama of no importance

höy tët nama It does not matter

tët dat nama not long at all

tët nama It does not matter

nama jenäh anything at all

nama-nama anything at all

namber $n a b E$ number

nanah nci pus

nanaq $n c h$ child; see also bernanaq have a child, be pregnant; anaq young of animal

nanaq bay cry-baby

nanaq busu youngest child

nanaq kemal twins

nanaq kilaki son

nanaq nibini daughter

nanaq radara unmarried daughter

nanaq tungan only child

nangäh cry; see menangäh

nanggri $n c i$ country, city, area

nanggri hatu place of the dead 


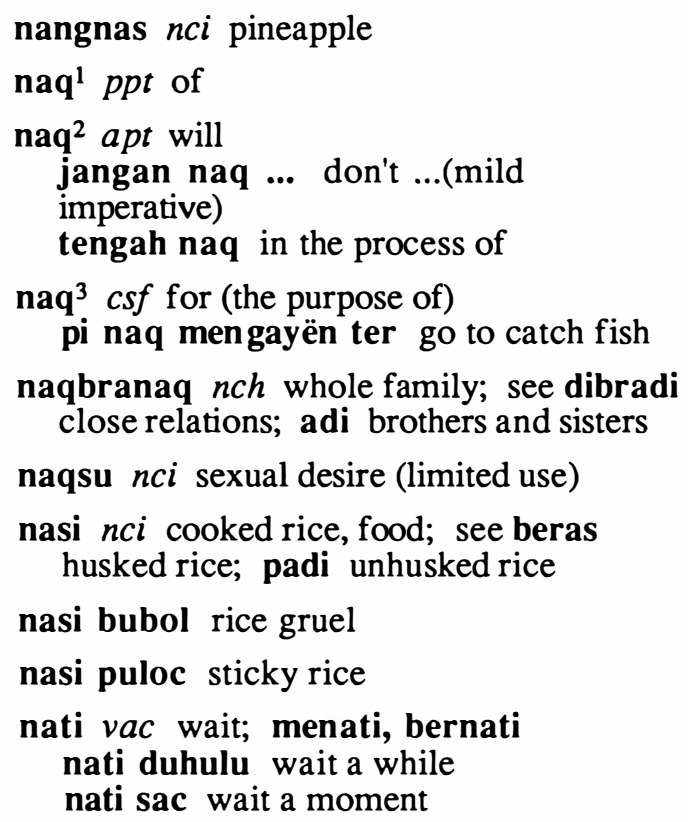

ngatöc vaci perch on

ngatoq vac be sleepy; mengatoq

ngëp $v a c$ chew betel nut; mengëp

ngemäng vac beg

ngenyah vaci make sea trip

ngetäq vaci twinkle

ngetäq sebelah wink

ngetäq-ngetäq vaj twinkling, blinking

ngetac vaci convulsed; ketac

ngetal vaci shake, shiver, have convulsions

ngitäq vact collect; mengitäq

ngng ejac Ah!

ngumol $v a c$ rinse (in mouth)

ngusöc vaci propel oneself while sitting (as a paralytic); mengusöc

ngutal vact kick

nguwaq vaci yawn

ni $d p t / s p t / d p n$ this; ini

nibini $n c h$ woman

nanaq nibini girl, daughter

nibini jalak prostitute

nibini jana widow

nibini radara young unmarried woman

nibrani avm bold; see brani

nidëh vaj boiling; menidëh

nikah vac marry; menikah, bernikah

nilëh vaci seep out, flow out; menilëh

nimaw vact construct; also timaw

ninäq $n c h$ great-grandparent, ancestor

ningay vac listen; see meningay

nipih vaj thin

pulaw nipih island in Adang group,

Satun province

nipon npp Japan; also yepun

nitay avt earlier (before time of speaking)

pagi nitay this morning

niyac vac vow; berniyac

plepas niyac discharge a vow 
nö $v p t$ final particle used with mild imperative or expecting agreement; also sac but not er or ler

nöl-anöl $n c a$ white ants

nöngklinöng avm sheltering; see linöng nöraka npl hell; also neraka

nora nci traditional manohra dance pala balay nora leader of the manohra team (see appendix)

nora miyok manohra dance variant

nori nci $E$ lorry

nu $r p n$ who, which nu-sa ... nu-sa ... the one ... the other

nu-caq that which

nu-sa the one, the other

nuba vact poison; tuba

nujop $n c h$ astrologer, wise man (often at royal court)

nulëh vact writes; menulëh, tulëh

nulëk vact exert oneself

nulok vact helps; menulok, tulok

nunang $n c i$ custard apple

nupak stay with, travel with; tupak

nutu nci olden times

duhulu nutu in the beginning

lagu nutu ancient story

lamula nutu in the beginning

sekala nutu in ancient times

taqdëq nutu since olden times

urak tuha nutu very old man

nya $p p n$ he, she, it nya dah That's right.

nyala vaci blaze; bernyala penyala flame

nyaman vaj tasty

nyamöq nca mosquito

nyang $n c h$ great-grandparent

inyang great-grandparent

munyang great-great-grandparent

nyang-munyang $n c h$ ancestors nyanyäq vact ascend, get on;

bernyanyäq

nyanyäq kaq san take to court

nyanyi vact sing; bernyanyi, menyanyi

nyanyoq vaci senile

nyapak vact paint; sapak

nyapëq ${ }^{1}$ vact look sideways, draw near (people or ships)

nyapëq ${ }^{2} a v l$ side by side, beside

nyarëq $v s p$ tell; carëq

nyari tadah seek an opportunity (tadah does not occur alone)

nyawa $n c i$ body, self; menyawa bernyawa breathe bernyawa besal sigh habih (ber)nyawa die hapa dëq nyawa all over the body tët senang nyawa not well yöm nyawa mati gave himself to die

nyawa taqasik oneself

nyelak vact open eyes

nyelap vaci dive; selap

nyemuh vaci bark (of a dog)

nying brerbiq vact blow by blocking one nostril

nyiru nci shallow winnowing basket

nyuloh nci head of penis

nyuroh $v s p$ send; suroh

nyuroq vact go underneath (see appendix)

nyu wang vaci fish with rod

O

o exc exclamation, $\mathrm{Oh}$ !

$\ddot{0}$ exc exclamation

öy exc exclamation

oc exc exclamation, $\mathrm{Oy}$ !

oh exc exclamation, $\mathrm{Oh}$ !

oq vact drink 


\section{$\mathbf{P}$}

pac $^{1}$ num four

pac sagi four-sided, square

pac sagi nu panyak rectangular

pac-belas num fourteen

pac-puloh num forty

pac $^{2}$ mpt (meaning uncertain)

pac $^{3}$ nci $A b$ place; tepac

pac-prac vact sow (seeds)

pada ppt $M$ at, from

padäq $n c i$ dagger

padak $n c i$ field (for sports, etc.)

padak tanah desert

padap vact put out

padap api put out a fire

padap hutak settle a debt

padat vaj fitting

padi nci unhusked rice; see also nasi cooked rice, bras husked rice

croh padi pounding with flat end of pestle

halu tutoq padi pestle for pounding rice hujok padi pounding with sharp end of pestle

lesok padi wooden mortar for pounding rice

menutoq padi pound rice

padi puloc sticky rice (uncooked)

pagal $n c i$ fence

pagi nci moming

gipagi in the moming

mahpagi tomorrow

mahpagi isa day after tomorrow

pagi nitay avt this moming

pah ejac amazement, dismay

paha nci upper leg, hip

pahac nci/vact chisel

pahadak nab protection; see phehadak

pahap vaj fluent

pahëq ${ }^{1}$ vaj bitter (to taste) pahëq ${ }^{2}$ nci pipe, tube, drill for boring

pajaq vact reserve

pajaq sarak burok contract to collect

birds' nests

pajaq ikat fish market

pakac vac agree; berpakac

pakan vact hammer caulking between the planks; see also makan to caulk a boat; lagala, compound used as caulking

pakay vact use, wear

terpakay useful

tët terpakay worthless

paku $n c i$ kind of fruit

pala ${ }^{1} \operatorname{cln}$ classifier for books

pala $^{2}$ nci head

angoq pala nod the head (assent)

ilik pala shake the head (dissent)

kepala leader

pala balay nora leader of manohra group

pala bubu entrance to fish trap

pala hatu skull

pala tupoq village leader

palah $n c h$ race, tribe, group

palah mökën Moken race

palah siyap Thai race

palu vact beat (a drum)

pam nci E/vact pump

panah $^{1}$ nci bow

panah $^{2}$ vact shoot (an arrow)

panaq vaj short

panaq-panaq avm in short bursts

panat $n p l$ Kaew Island, Phuket province

panaw nci skin disease

panay vaj clever

panay mita hujat able to control rain

pangin $v s p$ summon

pangöq vact raise up (e.g. head of snake)

panton nci $E$ pontoon

panyak vaj long

melaw panyak speak at length 
papat nci plank apal papat lay a plank floor

papat kemus plank holed

papat rihan railing on top of boat's side planking

papat toq $n c l$ table

paq $^{1}$ nch father

paq berhidoq adoptive father

paq metuha father-in-law

paq tiri stepfather

paq $^{2} m p t$ particle indicating censure

paqanaq nci anchor ring

tali paqanaq string loosely tying anchor

rope to ring

paqsenya nci evening

paqtajay $n p l$ Bua Island south of Surin Island

paqtapaq $n c i$ shoes

para nci grid or platform for smoking or drying fish

lubuq para village on Lanta Island

parah nch many

parak nci jungle knife, scythe

hulu parak knife handle

parëq vact return, come back

parëq-hati vaci repent

pari nca stingray

pari sengac nca manta ray

pas $v a c A b$ set free; see plepas

pasak $^{1}$ vaj tide coming in

pasak $^{2}$ vact install (engine, etc.)

pasan nci story, subject

pasan kena adu accusation

pasan nama why?

pasoq nci group

pasu nci basin

patac nci buttocks, stern (of boat or ship)

patah $^{1}$ vaj broken, snapped

patah $^{2} c \ln$ classifier for words or phrases patak $v a j$ forbidden (by tribal tradition) (see appendix); berpatak

patak nutu ancient customs

patay $n c i$ beach

patay raja $n p l$ Sri Raya town, Lanta Island

patët $n c i$ boil, pustule

pathaq vact pound (pile driver)

patoc vaj appropriate

patoq vact peck, strike (of a snake)

patot $v s p$ chant, mourn

pay-apay nca jellyfish with sting

paya vaj flat, level (of a place or area)

payah $^{1}$ vaj difficult, serious

payah lagi dëq harder than

payah $^{2}$ vaux take trouble to ...

tët payah takoc no need to be afraid

payok nci umbrella, shade

payoq nci propeller of boat

pëq $^{1}$ nci place

pëq ${ }^{2}$ ppt at, on, from

pëq dalap inside

pëq diha where?

pëq itu there

pëq ini here

pëq buraw Tepaw Island, Phuket province

pëtburi npl Petburi city

pebuwac nci action; see perbuwac

pecah vaj broken, split (of wood, crockery, etc.); berpecah

pecah kepala broken head

pecah-belah avm scattered, divided

pedak nci sword

pedas vaj hot, peppery

pedëh vaci smart (of eyes or a wound)

pedoq vact transport, convey (people or goods)

medoq place goods in ship or vehicle

pedudoq nci seat; dudoq

pedudoq naq raja king's throne 
pegak vact hold

gak-pegak holding

megak holds

urak pegak kemudi steersman

urak pegak setri driver of a car

pegu vaj coupled, paired

pehadak nab protection; see phehadak

pehagiq vac divide, share; hagiq

pehangac heated up; hangac

pehangac-hati flaming anger

pehapëq nci peg; hapëq

pehapëq sisë hair-slide

pe.isaq $n c i$ leaf cigarette; see pi.isaq

pejac nca bedbugs

pejal vact temper (iron)

pejap vact shut eyes

pejara nci jail

perjula nci violin; also ber jula

pekat $n p l$ name of area in Phuket town

peku.i nci kind of tree

peläq vaj $T$ strange, amazing

peläq-hati vaci amazed

peläq-peläq $a v m$ strange

pelaboh nci anchorage

pelacak nci ship festival; also belacak;

(see appendix, ari pelacak)

pelah vact catch fire

rumah pelah house on fire

pelah hangös burnt

pelanoq nca mousedeer; see planoq

pelat avm slowly, gradually

pelat-pelat $a v m$ gradually

pelat kurak pelat kurak gradually less

and less

pelatal $n c i$ floor, platform

pelay vaj splashing up

pelima nch $O$ captain (of boat)

pelita nci lamp

ubac pelita käkëp torch batteries pelitak crossed; see plitak

peloh vaci perspire; berpeloh

berpeloh nyawa covered with sweat

trerbëq peloh sweating

pelos vaci burn

terpelos bumt

pemesat $n c i$ command; see permesat

pemilok vaci drift

pemun vact collect, store away; see bermun

penac vaj tired

penakoc vaj fearful; takoc

pengacik nci button; also mengacik

penganyoh nci paddle; kayoh; see mengayoh

pengikay nci broom; kikay

pengipas nci fan, propeller (of ship);

kipas

pening pala dizzy

peninoq $n c i$ bed; tinoq

penöh vaj full

penöh kecac full, cramped

penulëh nci something written; tulëh

penyäq vact put on (clothes)

penyakëq nci illness; sakëq

penyakëq karak obstruction in urethra

penyakëq rubehiru leprosy

penyaköq nci hooked stick (as boathook, lobster hook, etc.)

penyala vac flame; nyala

penyamun nci robber; samun

penyarat nci toilet

penyawöq $n c i$ scoop-net

penyawoq $n c i$ scoop-net; sawoq

penyegat $v a j$ lazy; segat

penyelöq $n c i$ mortar of stone (for curry

ingredients); jelöq

penyengac nci sting, itch; sengac 
penyu nca turtle

penyudah vaj last (in time or place); sudah

penyudöq $n c i$ shovel

penyuri $n c h$ thief; curi urak penyuri thief

penyuroh nch messenger, servant; suroh pepaq vact chew

pepu $v a j$ fine (in texture) jelöq pepu pound until fine

perbuwac nci acts or things done; buwac pergi vaci $M$ go

perkat vact compel; see prerkat

perlëh $n p l$ Perlis state, Malaysia; see prerlëh

permelaw $n c i$ word, speech; melaw permesat $n c i$ command; pesat

permun vact collect; see pemun

pernana $n c i$ indications, bearings; tana

pesaka $n c i$ inheritance

pesat $v s p$ command, order; bersat, (me)mesat, permesat

pesuc vaj accomplished, finished (as in buwac pesuc)

ku naq gagah buwac pesuc äq I will certainly finish the task (answering an exhortation to finish task)

petat vact arrange, prepare, mend petay $n c i$ tree bean

pethöl $n c i$ verandah

pethuy vact spit out (with force)

peti $n c i$ box peti (ber)bungi gramophone jarop peti berbungi gramophone needle

petiq vact flick finger with other hand petöq vact touch (purposely, with hand) petok $\mathrm{npl}$ village on Peepee Island, Krabi province

phahadak nab protection; also phehadak phahagët $n c i$ share; hagiq

phahagiq vact divide, share; hagiq

phahala $n c i$ good deeds

phakhac apt collective action; berphakhac, khac phakhac maräh prachum together came to the meeting

pharaq nch slave, agent Noh ter, nya pharaq Tuhat Noah was God's agent

phehadak nab protection; also phahadak (see appendix, ari phahadak)

phiraw vact tack (of sailing boat)

phoq nci On bang (sound of a shot)

phrat $^{1}$ nci wooden mask worn by male dancers in manohra dance

phrat $^{2}$ ave very phrat banyaq phrat banyaq more and more

phrengan nca swordfish

phrengay $n p l$ Hai Island (near Lanta Island)

phrerdap $\mathrm{npl}$ morning star

phrerlak nca stingray

phrerlap nci evening star (not called a bitak)

phru avm acting as a group

phunyay $n c l T$ headman

phuq-phuq vaj dropping

pi vact go berpi lead

picok vact steer boat at angle to waves and wind

pi.isaq nci leaf cigarette; also pe.isaq baloc pi.isaq roll a cigarette cucoh pi.isaq light a cigarette dawot pi.isaq leaf for cigarette; isaq

pik $n c i$ sticky rice preparation, fried and pounded

piköq vaj curved, bent

pilëh vac choose, select; memilëh 
pinang $n c i$ areca nut

pingak $n c i$ waist

tali pingak belt

pingay $n p l$ island name

pinyäq vact crush

pipëh vaj squashed, shrivelled

pipi $n c i$ cheek

piraq $n c i$ silver

pirik nci plate

pisak nci banana

sak-pisak rubbing strake (on boat)

serawa pisak banana biscuit

pisaw nci knife

pitas vact intercept; go to windward

pitu nci door

buka pitu open the door

kapus pitu shut the door

tudok pitu shut the door

piyoq nci saucepan

tanah piyoq api gunpowder

tapoq piyoq saucepan lid

piyoq nasi rice saucepan

piyoq tanah earthen saucepan

planoq nca mouse deer; also pelanoq

plepas vact set free; lepas

plepas niyac discharge a vow

plihac vact reveal, manifest; lihac

plikac vac igniting

plitak vaj crossed (as two pieces of wood) kayu plitak cross, crucifix

pöc-pöc vaj wrapped around

kayët pöc-pöc cloth wrapped around baby

pok $n c i$ Ab cake; see tepok

pot $s p t$ particle showing mild emphasis itu pot That's it! pot belëh It will do.

prabok nci peaked roof, ridge capping (on house or coffin)

prahu $n c i$ boat prahu kumal boat built from zalacca palm

prahu lunas boat of dugout type

prahu pelacak boat for spirit festival

prahu timaw boat built of planks

prak $^{1}$ nci war; berprak

prak $^{2}$ vact toss, scatter, sow

prakay vaj coupled together

prangay ${ }^{1}$ nab disposition

prangay ${ }^{2} a v m$ by nature prangay kita buwac taq.asik tët belëh By nature we cannot do it ourselves

praqchum nci $T$ meeting

prasoh nch servant, slave

prerciq vact flick, sprinkle (water, as in sprinkling a corpse or sprinkling perfumed water on friends)

prerdu nci trunk of tree or plant

prerkat $^{1}$ vact compel

prerkat $^{2}$ vaux persist in

nya prerkat makat $\mathrm{He}$ persisted in eating.

prerkoq vact bring together, combine

prerlëh $n p l$ Perlis state, Malaysia

prerlök nci hole, crevice, opportunity

pring-pring nci long Mon drum

prös $n c i$ joist

proc nci stomach, abdomen

berproc be pregnant

proh vact drive out

prulu nci arrow, bullet

prutoh vact demolish, knock down; rutoh

pucoq nci top, tip (of tree, shrub)

puhot $^{1} \mathrm{ncl}$ classifier (for trees)

puhot $^{2}$ nci tree

puhot asap jawa tamarind tree

puhot kayu tree

puhot kelamël coconut tree 
puji vact praise; (me)muji

pujoq vact comfort; (me)mujoq

pukac nci net (large)

irëq pukac draw a net, trawl

jahëq pukac sew up a net

mukac fish with a net

mukac yepun fish with Japanese-type

net

telapok pukac float on a net

pukol nci hour, time

pukol brapa What time is it?

pukol tiga three o'clock

pulak ave again, further

pulak dah ter nama once again

pulas $^{1}$ vact revolve, turn, screw (on its axis)

pulas papat twist a plank

pulas tali spin a rope (before throwing)

pulas $^{2}$ vsp deny

pulaw $n c i$ island

pulaw bunga Dokmai Island

pulaw dagik island in Satun province

pulaw denak island in Ranong province

pulaw gajah Elephant Island

pulaw hujok island near Raya Island,

Phuket province

pulaw kecap Jum Island, Krabi

pulaw keladi island near Surin Island

pulaw krët Green Island

pulaw lathaq Surin Island

pulaw meriyap island near Surin Island

pulaw mrerpu Crab Island, Krabi

province

pulaw paqtajay Bua Island

pulaw phrengay Hay Island, near Lanta

Island

pulaw pingay island name

pulaw satak Lanta Island

pulaw semilat Sembilan Islands

pulaw trupak island name

pulëh vact anoint, wash (boats and nets)

puloc nci sticky rice (cooked)

puloc kunyäq glutinous rice with

cummin

puloh num tens

sepuloh ten

lima puloh fifty pungöc vact reap, gather (large items);

(me)mungöc

pungöc taroh store (rice, etc.)

pupang nci crab trap

pupoh vaj taboo (see appendix)

pupot nca worm used for bait

pusac nci navel

putëh vaj white

putiq nci small coconut

putus vaj cut off, lacking

puwah vaj ripe, fully cooked

puwaq vaci overflow

puwas vaj satisfied (of smoking cigarettes, etc.)

puy-pruy vac sprinkle, sow (by sprinkling)

puyoh nca quail

$\mathbf{R}$

räq-giräq cukuk small push-cart

raba vact grope; meraba

racot vact poison

ubac racot poison

radara $n c h$ young woman, virgin

raga $n c i$ basket

ragi nci colouring, yeast, additive roti höy ragi unleavened bread

rahoq vact scoop up (goods)

rahu $n p p$ mythical giant (who tries to consume sun/moon in an eclipse)

rahura avm $T$ extravagantly

raja nch king, official pedudoq naq raja king's throne

rajët vaj diligent, industrious

rakaq vaci crawl, creep; merakaq

ramay vaj fun, crowded; beramay beramay celebrate together, have fun together, festival

ramay-ramay avm happily 
ramin vaj jute, linen

tali ramin jute thread

ramoc $n c i$ rambutan

rangok nca long-legged waterbird

rangwan $n c i T$ reward, payment

ranoq vact forge into (jungle, etc.); branoq, manoq

ra.op nab nice smell (as of food, flowers, scent)

rapac $^{1}$ vaj close together

rapac $^{2}$ avm constantly

rapah nci rubbish

rapas vaj grasping; berapas

raq-raq $O n$ sound of fish on surface

raquq $^{1}$ vaj noisy (as of many speaking together)

raquq $^{2}$ avm together (many people) menangäh raquq cry together

raquq-raquq $a v m$ together

rasa $^{1} v s p$ feel; berasa, brasa, merasa berasa bejäq feel cold berasa ter jihat juga feel pity

rasa $^{2}$ vaux be able (usually negative) tët rasa makat nasi unable to eat rice tët rasa pi not able to go

rasoq $v a c$ addicted, possess (of spirits) merasoq possess, indwell rasoq hatu demon possessed rasoq kaq araq addicted to drink rasoq kaq nibini womaniser

rata ipn every, all rata deniya all the world rata semiya every man

rata-rata ipn everywhere semiya rata-rata people everywhere tuhat rata-rata Lord of all

ratay $n c i$ chain ratay lihël neck chain ratay mas gold necklace

ratik $n c i$ twig, stem

ratus num hundred seratus one hundred duwa ratus two hundred rawac vac row (facing the stern); berawac rawak nci space

rawak bukëq valley

raway $n p l$ Rawai village, Phuket

rawoc vact whittle

reba nci small branch

reba kayu small branch of tree

rebah vaci fall over (person, bicycle, tree)

rebok nci bamboo shoots (for cooking)

reboq $n c i$ seed pearls

rebus vact boil

reda $v a j$ diminished, reduced (water, wind, rain, etc.)

redop vaj dull, overcast

dop-redop overcast

regäng $n c i$ accordion

rega $n c i$ price, value; brerga

regac vact summarise

regak vact pull

regak berbikas pull to an upright position

regu vac blow (breathe)

rema avm together

remak $^{1} v a j$ straight (of line or road); fulfilled, faithful

tinyung remak look straight ahead tuhat nu remak God who is faithful

remak $^{2}$ prep opposite

remay vaj feel faint or weak

renah vaj low renah dëq lower than

renak vact fry nachuq renak fried chilli sauce nasi renak fried rice

renap vac soak, dip in, sit in water

rengak vaj separate (of companions or goods)

rengap $n c i$ small reaping knife

renök $n p l$ Renong town

renyas vac bounce 
repëh vaj chipped

repëq vact whip, beat

repoh vact chop, hack (with axe)

reröc prep reached to

resaq vact rub gently, stroke

retaq ${ }^{1}$ vaj cracked

retaq $^{2}$ vaux about to

rethöc vact raise a diver

ri.ari avt daily

riba vact carry in arms, nurse (on lap)

ribal vact exchange, change (objects)

ribas $n c h$ royal servant

riboc $n c i$ storm, strong wind

ribradi relations; see dibradi

ribu num thousand

riciq vact split, cut across (waves)

ricok nci clasp-knife

rigaq vact catch, arrest; merigaq

segu rigaq ciyup a couple snatch a kiss

rihan ave light (in weight)

ringëq nci Malay dollar

rinyiq ave very small, tiny

risaw vaj annoyed

risaw-hati $v a j$ angry

ritih vac rain sprinkling

riwak vact hurl, cast, fling

riway vact swing jalat riway walk with swinging arms riway tangan swing arms

riyok $n c i$ freshwater reed

röc vact reach; reröc manyak-röc forever naq röc will happen reröc reached to röc dah Arrived! (greeting)

röc-kaq prep as many as, reaching to

röntri nci electricity

api röntri electric light bulb

tali api röntri electric powerline rönya vaux let go, Never mind (it)!

rongräm nci $T$ hotel

rongrian $n c i T$ school

rongyaban $n p l T$ hospital

roti $n c i$ bread

rubehiru vaj dirty, objectionable; also rubiru

rubiru vaj dirty, objectionable; also rubehiru

rumah nci house

rumah berkira meeting room

rumah datoq spirit house

rumah kramac spirit house

rumah pelët witchdoctor's spirit house

rumah praqchum meeting room

rumah saröq temporary hut

rumot vact kindle, blow on (fire)

rumot api light a fire, build a fire

rungëk nci Malay-type dance

rupa $^{1}$ nci fashion, kind

rupa $^{2}$ prep like

rupoc $n c i$ grass

ruraq-ruraq avm On sound of light rain

ruru vaci flow in quantity

ayë berlari ruru the water runs in quantity

rusa $n c a$ deer

kana rusa kind of leaf used in medicine

rusoq $n c i$ side tulak rusoq rib

rutoh vaci collapse (of house, mast) prutoh demolish, wreck, break off

ruwak nci room ruwak atas mata.ari inside room (facing east)

ruwaq-ruwaq nca tadpole 
S

sälöng $n c i$ Ceylon tea

$\mathbf{s a}^{1}$ num one; also saq, se

$\mathrm{sa}^{2}$ ave only

sa.at nci medicine for fontanelle of baby

sabac $n c h$ friend

sabal vact stop a fight

sabëq $c s$ because

sabëq-nama why?

sabok nab contest

sabot $n c i$ soap

sabrasa ave sufficient, just a little

sac $^{1}$ avt presently, sometimes

sac ... sac ... sometimes ... sometimes

sac-sac avt often, in a moment

$\operatorname{sac}^{2} v p t$ final particle used with mild imperative; see nö

sadap $n p l$ Maprau Island, Phuket

sagak vact intervene (in a fight)

sagi nci angle, comer (of table)

sagol $n c i$ junk

sah vaj clear (of speech or sight)

saja avm $M$ only

mati saja die pointlessly

sak-pisak nci rubbing strake (on boat)

sakëq $v a j$ sick, sore; penyakëq

lawat sakëq endure sickness

sakëq bisa extreme pain, pain of infected wound

sakëq demam sick of fever

sakëq pala headache

sakëq-hati jealous

sakoc vaci hang on (wall, etc.)

sal-besal vaj great, important

salah $^{1}$ nab fault

akëq salah forgive a wrong

amët salah find fault

salah $^{2}$ vaj wrong, at fault salah lagu wrong behaviour

salah urac twisted sinew

salah-hati vaj annoyed

salay vact roast, barbecue

salay ari vaci dry in sun, sunbathe

salët vact change; menyalët

ulal menyalët snake changes its skin

sama ava together; bersama

sama-hati mita ask unitedly

sama-sama ava together with

sami $n c h$ priest

sami awaq Burmese priest

sami hutat hermit

samoc vact receive, welcome

samoq nci dinghy

samun vact rob; (me)nyamun, penyamun

san $n c i T$ court

sanal vact rely on, lean on

sanga $n c i$ forked support used in boats

sangon $n c i$ hairbun (female)

sangoq vact receive, admit

sa.öp vaj warm

sapa $^{1}$ qpn who?

sapa $^{2}$ ipn anyone, whoever

sapak vact wipe, paint; menyapak, penyapak

sapat nci small dinghy with square bows

sapoc $^{1}$ vact wrap around; bersapoc

sapoc $^{2}$ nci husks

sapoc kelamël coconut husks

saq $^{1}$ num one

saq $^{2}$ vact $O$ reached to

saqdi $n a b$ mystic word; see sidi

saqsi $n c h$ witness

sarac vaj overloaded (boat)

sarac naq talap almost sinking 
sarak $n c i$ nest

sari vact seek; (me)nyari

saröq $n c i$ temporary hut

sarop nci skin of snake

buwak sarop (snake) sloughs its skin

sasa avm one by one

sasac vact examine, inspect; menyasac

satak $n p l$ Lanta Island, Krabi province

satat $n c i$ coconut milk

satu num $M$ one; bersatu

sawa nca python

sawoc see bersawoc pray

sawoh $n c i$ anchor

akëq sawoh raise the anchor

böh sawoh place the anchor jala sawoh throw out the anchor sitaq sawoh pull in the anchor tabol sawoh throw out the anchor

turot sawoh lower the anchor

sawoq vact scoop (in water)

saya vaj bright; bersaya

sayac vact slice off

sayak vact love

sayaq $n c i$ wings, stabilising fins

sayman nci $T$ cord for drawing in fishing net

se- num one; also sa, saq

se.ari one day

sebanyaq-banyaq ave as much as possible

sebarak nca goods

sebaya avm equally

sebelah one side

sebelas num eleven

sebilat see semilat nine

seboc $v s p$ be called, utter

sebul vact spray (see appendix)

sebuwah one body

secalok one tinful sedagah nch Sikh

sedal $v s p$ be aware of

sedal caq be aware that

sedekah nci $M$ Muslim gifts to the poor

segat vaj lazy; (me)nyegat, penyegat

segengap one handful

segiwak-segiwak avm back and forth as a drunk (of walking)

segoq vact leap on

segu one pair

se.ikol one (tail) (= one creature)

sejurus avt presently

sekac vact block, obstruct

sekac penyakëq protect from disease

sekali avt once

sekali dikiq little at a time

sekawat $a v m$ as a group

seketon $c l n$ large piece

sekrac one portion

sekuna nci $E$ old sailing vessel (used as model for spirit boat)

seläq vact attach to

selagu another matter

selalu ave very much, always

selama-ini avt at this time

selamac nab blessing

bri selamac give thanks, bless

selap vact immerse; (me)nyelap

selaq vaci faint

selaqsa ten thousand

selatat $n c i$ south-east

selesay vaj completed (court-case or prison term)

seloq vact reach into

selunay nci trumpet

seluni vaci hide (person, animal)

seluwal $n c i$ trousers 
semah vact worship, offer to;

(me)nyemah

semak kajak mat roofing

semak layal mat sail

semanyak-röc avt forever

semaq vaj disorderly, untidy, cluttered

semata $a v m$ wholeheartedly

semay $n c i T$ age

semayak nci Muslim time of prayer

semën $c c$ at the same time

semekët vaj $O$ poor

semengac $n c h$ spirit

semengac dëq pala crown of the head

semilat num nine

semiya nch man

semiya berkasëh adulterer

semiya berkira committee men

semiya kaq kita man like us

semiya menurot medium (demon possessed)

semiya pakay ayë lemu witchdoctor

semiya penyala net fisherman

semöc nca ant

semöc krernga red ants

semoh vaj healed

semuha ipn all, altogether

senan vact support, steady

kayu senan prahu wooden supports

steadying a boat hauled up to be mended

senang vaj happy, contented

senang-hati $v a j$ content, peaceful of heart tët senang nyawa unwell

senapak nci gun, rifle, cannon

senasi vac eat together

pi usiq senasi have a meal together

senata $n c i$ weapons sengac $^{1} v a j$ poison, sting; penyengac pari sengac poisonous manta ray sipoc sengac cone shellfish (poisonous)

sengac $^{2}$ vact restrain

sengaja vaux act in pretence nya sengaja naq pi he pretended to go

sengan pala have headache

sengaq vaj quietly

sengaq-sengaq avm quietly

sengaraq $v s p$ cry out

sening $n c i$ kind of fruit

senoq $^{1}$ nci serving spoon

ulal tedok senoq cobra

senoq $^{2}$ vact spoon out (curry, soup, etc.)

senoq besi $n c i$ frying ladle

senya $n c i$ late afternoon; also henya malap senya last night

sepa $n c i$ seed of a vine

usiq sepa game played with seeds

sepäq vaj narrow

sepac num group of four

sepap $\mathrm{npl}$ Sepum village, Phuket Island

sepaq see srerpaq almost

sepring nci $E$ spring

sepuc vaj inept, inefficient

sepuc-sepuc avm with difficulty menyawa sepuc-sepuc gasping for breath

sepuloh num ten

serapak nci spear (3-pronged)

seratus num one hundred

serbak avl other side (of river, etc.); see srerbak

seri vaj outstanding; berseri

seribu num one thousand

serma nci cold; see srerma

serpaq ave almost; see srerpaq 
serupa prep like, the same serupa jangan same as serupa kaq similar to, as if

sesac vaj astray sesan see menyesan feel sorry for sesungoh ave truly setana cs when, as setang $n c i T$ Thai coin setat vact $E$ start (engine) setengah $^{1}$ ipn some setengah $^{2}$ vaj half setenös ave in sections setepac one place setipäq $c \ln$ piece, slice seton nci revolver, pistol setri $n c i$ vehicle setru nci $T$ enemy setukin nci $E$ socks se.umöl avl lifelong; umöl se.urak one person si.ap vaj Thai

sibal vact sprinkle (with the hand)

sidëq $n c i$ piece of bamboo (used in looking for lice)

sidi vaj superhuman, miraculous permelaw sidi superhumanly powerful word

urak sidi someone with superhuman powers

sidöq vact lean against

sik-masik ave each one

sikac vaj not long enough

sikën gigi have severe toothache

siku nci elbow, corner

silaq vact look for lice

simöy vaj dirty, overcast

simöy-simöy vaj dirty, overcast

singa nca lion singah vact turn aside, stop at

singi ${ }^{1} d p t$ just now

singi ${ }^{2} d p n$ matter just mentioned

sipaku nci nail

sipaq vact kick

buwah sipaq takraw ball

usiq sipaq play takraw

sipaq sila kick with sole of foot

sipay vact twist together, plait

sipoc nca shell

siräq ${ }^{1}$ vaci turn around (with hand held up as in Manohra)

siräq2 vact approach a superior

sirac vact lash, tie down

sirëh $n c i$ betel leaf

sisën $n a b$ bad luck

sisiq $n c i$ fish scales, turtle shell

sita $n c i$ horizontal supports inside boat

sitaq vact haul

sitaq rupa take a photo

sitat nch Satan

siti nch $M$ lady

siti hawa $M$ Lady Eve

siwa vact hire, rent; bernyiwa

siyak nci light, daylight; bersiyak soq siyak daytime yu bersiyak until daylight

siyak malap day and night

siyaq vact prepare; bersiyaq

siyok nci horn (of animal); PYP also use of elephant's tusk; see gadik

siyon vact whistle a tune

siyon dëq muloc whistle call (not UL practice)

sön nci pus, core of a boil

söpöng nci Chinese tin mine

söq $n c i$ lung 
soh $v s p A b$ request, command (contraction of suroh)

sok ipn each sok semacap one of each kind

sok-sok vaci stumble

soksa ipn one of each

soq $^{1}$ nci area

soq $^{2} p p t$ location at or beside

srerbak $a v l$ other side (of river, etc.)

srerban $n c i$ hadji's turban

srerbat $n c i$ hadji's turban

srerkoq ${ }^{1}$ vact pounce on

srerkoq $^{2}$ nci wicker pen (placed over

fighting cocks)

srerma nci cold

srerpaq ave almost

srertak avt all the time, continuously

sröq vact digest, taste

su-asu nci cowrie shell

su-asu bertelak patterned cowrie shell

subak $^{1}$ nci portion of flesh on shellfish

subak $^{2}$ nci earrings

suc $^{1}$ vact finish

suc $^{2} v p t$ finished action

sudah $^{1}$ vaci finish; penyudah

sudah $^{2}$ vaux finish

sudah $^{3} v p t$ finished

sudöq vact scoop out, excavate

sudu nci spoon

sugël $v a j$ hanging down

suka ${ }^{1}$ vact like

suka $^{2}$ vaux like to

suka tët habih did not like it much

suka-hati vaj happy, pleased

suläw $n c i$ penis

kulë brulak deq suläw foreskin

sulap vact gobble up (persons only) sulok vaj eldest (child)

sumak vact nuzzle

sumök vaj self-assertive, ruthless

sumu nci wick

sunay see selunay wind instrument

sungay nci river

sungay batu gorge

sungay brana $n p l$ village on Pu Island

sungoh vaj true sesungoh truly

sungoh-sungoh ave truly melaw sungoh-sungoh enter into agreement together

supah $v s p$ curse, swear, take oath; bersupah

supat $n c i$ playing cards

supaw nci steamed fish curry

supëq ${ }^{1}$ vact blow, puff

buloh penyupëq blowpipe

supëq $^{2}$ nci small rice bag

surac nci book, letter

suraq $v s p$ shout; bersuraq

suraw nci mosque

suray nci comb

suroc vaci fall (tide)

ayë suroc tide is falling

suroh $v s p$ send, use; (me)nyuroh, penyuroh

lebëh dëq suroh more than enough suroh duwëq banyaq spend much money

susah vaj trouble

susah-hati vaj sad

susoc vaj thin

sutoq vact gobble

suwa vact contact, meet

suwa mukha meet someone

timaw bri suwa mukha not want to see their face

suwac vact throw out, splash 
suwal vaci shine

api suwal projection lamp

suwara nci voice, sound

\section{$\mathbf{T}$}

täk vact carve

tabëq vact rub on

tabol vact toss, sling (with sideways arm motion)

tabot vaci make merit; see tehabot

tadah nab opportunity

tagat nci capital, cash on hand

tagëh vact crave (satisfaction for an addiction)

tahat vac suffer; bertahat

batu tahat stone used as a wedge

kayu tahat wooden fulcrum for bending

a plank

tahi nci excrement, dung

tahot nci year

tahu vsp know; bertahu

bri tahu tell, inform; see bitahu

tajap vaj sharp

takan nci charm string (sign of vow) (see appendix)

takay nci ear (of grain)

takay padi ears of rice

takoc vact fear; (me)nakoc, penakoc

taksal nci swamp tree

talak nca large kind of fish

talap vac sink; (me)nalap

tali $n c i$ rope

tali api radio aerial

tali api röntri electric power line

tali graq telephone, telegram

tali kayën fishing line

tali pingak belt

tamäq nci heavy kitchen chopper tamäq cina Chinese chopper

tamäq si.ap Thai chopper

tamah vac add to; bertamah

tamak nci fare (on vehicle or vessel)

tamata nch police

tamot vact fill in (earth)

$\operatorname{tana}^{1}$ nci mark, symbol, bearings; pertana $\operatorname{tana}^{2}$ cs when, just as

tana berbihak first glimmer of dawn

tana crah when it was light

tana-bajiq just then

tana-tana avt whenever

tanah nci ground, dirt

kayu tanah wood planted in the ground

tanah bringöq earthquake

tanah liyac clay

tanah piyoq api gunpowder

tanam vact plant, bury; (me)nanam

tanam hatu bury a corpse

tang nci $T$ money

tanga nci ladder, stair, boom of a dredge

tangan nci hand jap tangan wristwatch

kaki tangan feet and hands

tangcaw nci crowbar

tangok vact carry on shoulder

tanoq nci hom of animal

tanya $v s p$ enquire; bertanya, (me)nanya

tanyok nci promontory

ta.öq nci poultice

tapäq vact stick on

tapal vact slap face

tapaq nci palm of hand, sole of foot, footprint

tapaq kaki sole of foot

tapaq tangan palm of hand

tapën vact spread (disease) 
tapi $c c$ but

tapi-caq $c c$ however

tapih vact toss, bounce, winnow

tapö $\mathrm{npl}$ village on Lanta Island

tapoq $^{1}$ nci lid, stopper, cork

tapoq penutok covering lid

tapoq ${ }^{2}$ vact close

taqarah vaj dirty, objectionable

taqasik ipn oneself

hidoq taqasik have life of one's own

kita taqasik we ourselves

nyawa taqasik himself

taqaw $n p l$ Hey Island, Phuket

taqdëq prep ever since, right from taqdëq itu maräh ever since then taqdëq nutu since olden times

taqëm nca sea urchin

tara nci north

tarik nci tusk of wild pig

tariq vact drag, draw up (boat)

taroh $^{1}$ vact place taroh dëq hati remember something usiq bertaroh gamble

$\operatorname{taroh}^{2} v p t$ completed action (of a temporary nature)

taroh-hati vact trust

taroq $n c i$ vegetable

taroq kakok convulvulus

tawal ${ }^{1}$ vac bargain

tawal ${ }^{2}$ vaj tasteless, fresh

tëng $n c i$ tin (up to 4-gallon size)

tëp nci $E$ tape recorder

tëq-jetëq $\mathrm{avm}$ limpingly (of walking)

tët neg no, not

suka tët habih did not like it much

tët (ber)guna evil, wicked

tët brapa not many

tët cadak naq hidoq no hope to live

tët caq no matter what

tët dat nama not long at all

tët sedal not conscious tët senang nyawa not well at all

tët terpakay worthless, useless

tët tetu arah uncertain

tebak vact chop down

teban vaj thick

tebas vact slash down

tebik nci slope

teboq vact cut a hole

tebu nci sugarcane

teburok nci flesh of coconut

tebus vact ransom; menebus, penebus

tedaq prep until; also terdaq

tedaq röc until

tedoh vaj calm (sea, wind)

tedok-senoq cobra

tedus vac stumble

tedus-hati offended

tegah vac argue, quarrel; bertegah

tegal vaj strong

angën tegal strong wind

umaq tegal heavy sea

wayak gelaq tegal slide show

tegal urac strong (in body)

tegal-hati vaj stubborn, obstinate

tegala vact plough

tegoh vaj lasting (of rope, cloth)

tehabot vac make merit; also tabot

tekat vact press, choke, strain (wood), oppress

tekös nci boundary

teläl vaci shine; berteläl

teladoq $n c i$ thole (of rowing boat)

telaga $n c i$ well

telanyak vaj naked

telapok nci float, buoy, weight

telapok ikuwa weight (on fishing line)

telat vact swallow

telinga $n c i$ ear 
telol nci egg, testicle

teloq $n c i$ bay

telul $n p l$ Lone Island (near Phuket)

temaq vaci bow down, bend over

temesu nci kind of (heavy) wood

temiloq nca marine worm

temirak nci guy-ropes (of mast)

temoq nci ant mound

temuku nci ankle

temus vact pierce

temus kira think through to a decision

tenak $n p l$ island in Burma

tenang vaj calm (sea)

tengah ${ }^{1}$ prep middle of

tengah ari midday

tengah malap midnight

tengah $^{2}$ cs while

tengah $^{3}$ apt in the process of

tengah naq in the process of

tengah-tengah $a v l$ in the middle

tengaq vact cook, place

tenöng vact aim at, steer for

tenöng dëq tana to aim at a mark

tepac naq tenöng place to aim at

tenös nci joint, verse

tenös-tenös ave in sections

tepac $^{1}$ nci place

tepac dudoq seat

tepac linöng hiding place

tepac rata flat place

tepac tanah block of ground

tepac tinoq bed

tepac $^{2}$ vaj straight, upright

bajiq tepac righteous

hati tepac upright heart

tepëq $v s p$ shout angrily

tepët $n c i$ port

tepok nci cake, flour

tepoq vact slap, clap (hands)

umaq tepoq prahu waves slapping against boat

See also tapal slap the face

ter $s p t$ syntactic particle

terajak vact kick with soles of feet

terbëq vac depart, issue out of; see trerbëq

terbët $n p l$ place with a shrine ujok terbët datoq name of cape

terbrengaq vaci stumble backwards

terbuwak vac thrown away; buwak

tercihat vact pity

terdaq prep until; also tedaq

tergäq vaci choke

tergamam vaj startled out of one's wits

tergamaq vaux not wishing to

terguläk vaj lying prostrate

terhutak vac in debt; hutak

teringi $n c i$ creeper with small berries

teritëq $n c a$ oyster

ter jot vaci jump down

terkejuc vaj startled

terketap vac reaped; ketap

terkimaq exc $V$ swear word hapot maq terkimaq swear word

terlalu ave very, exceedingly

terletak vac lying face up

termika nci pearl

ternama vac named; nama

terngetac vaj convulsed; ketac

terpakay vaj useful

höy tët terpakay worthless

nu terpakay important

terpeliq vaci slip off, slip over, dislocate (bone)

terpelos vaj burnt; pelos

terpido $n c i$ torpedo

terpiyok nci tornado, waterspout

terubuk nca flying ants; see trubuk 
tetaq vaj stable (boat)
tetas vact $O$ cut (a rope)
tetu vaj sure
kira tetu decide
thancay nci $T$ painkiller
thaqbian nci $T$ register
thaqhan nch $T$ soldier
thok nci $T$ container, bag
thok ayë water drum
thok baju shirt pocket
thok plätik plastic bag

thuraq nci $T$ business

tibuk nci charm (protecting fruit on a tree)

tiga num three

tiga-belas num thirteen

tiga-puloh num thirty

tihak nci pole, mast

tihak kapan mast of ship

tikäq $^{1}$ nci $E$ ticket

tikäq ${ }^{2}$ vac write, inscribe; also sikäq

tikah vsp answer

tikah parëq answer back

tikap vact stab; (me)nikap

tikaq $n c i$ window

tikök nci $O$ steersman, extra payment (for steersman)

tikus nca mouse, rat

tikus urak putëh white mouse

tilat $n c i$ beam

tiliq vact turn aside, avoid

tima vact bail out (water)

timah $n c i$ iron

timang vact weigh, ballast, balance

timang-hati vaj considerate

timaq vact shoot

timaw ${ }^{1}$ vaux not want

timaw $^{2}$ vact construct; see nimaw timöl nci east

timön nci cucumber

timön kayu nci papaya

timön malikay melon

timon vaci float; bertimon

tinas vact squash a flea

tingan vact leave, abandon; meningan

tingi vaj tall, high

tinoq vaci lie down (to sleep)

tinyung vac gaze

tinyung remak look straight ahead

ti.o nci $T$ trip

tipäq $c \ln$ classifier (for slices of fish)

tipaq nci bag

tipu vact deceive; (me)nipu

tiqutiq nca mosquito larva

tirih vaj holed, leaking

tiroq $n c i$ fish spear

titiq vac drip; (me)nitiq

tiyoq vact blow (a wind instrument)

töc ave tiny piece

demiq töc very small

dikiq töc very few

tök nci cubit

tökkë nch towkay (Chinese middle-man)

tökkha npl Phuket town

töklöng vac $T$ decide

töq-utöq avm limping

tötö vac $T$ pass to another penyakëq tötö infectious disease

töyketöy nci uvula

tolaq bala rite to avert calamity (see appendix)

topi nci Muslim skull cap

toq $^{1}$ nci $T$ table; see papat toq 


$$
\begin{aligned}
& \text { toq }^{2} \text { nch Muslim elder } \\
& \text { toq adap Adam } \\
& \text { toq } \mathbf{j i} \text { nch hadji } \\
& \text { toq ninëq ancestors }
\end{aligned}
$$

toq $^{3}$ exc Muslim expletive

toqkök nci Chinese temple

toqsäq $n c h$ Muslim imam (higher status than hadji)

tras nci crossbeam

trerbak vaci fly kapan trerbak aeroplane

trerbëq vac depart, issue out of isuc tët trerbëq rubbed but not erased

trer jot vact jump down

tripak nca sea slug

trök nci eggplant, brinjal

trök mirah nci tomato

trök pulaw pinang type of berry

troq ave truly

troq-troq very

trubuk nca flying ants; also terubuk

trubuq $n c a$ kind of fish

trupuk nci telescope

tu.at nch $M$ master

tuba $^{1}$ nci poisonous plant

tuba $^{2}$ vact poison (fish, etc.); (me)nuba

tuboq vact chisel out

tudoh $^{1}$ vact blame, accuse; bertudohtudoh

tudoh $^{2}$ vac prophesy, forecast

tudok vact shut, cover

tudok dusa cover sin

tudok nyawa cover the body

tuha vaj old

tuha muda old and young

tuhat nch God, owner

tuhat berhidoq God who gives life

tuhat besal God

tuhat besal dëq atas God tuhat dëq atas God

tuhat rumah owner of a house

tuhat tanah spirit of a place, landowner

tuhëq vact zealous for, serve hati tët tuhëq heart not right

tuhol vaj dried

lada tuhol dried peppers

layu tuhol dried up

ikat tuhol dried fish

cf. krik dry land

tuhoq vact stretch out, toss, cast (spear) ikat tuhoq swordfish

tuhoq lakah stretch a pace (child learning to walk)

tujoh num seven

tuju vact flick

tuju usiq sepala game played with seed pods

tukac nci walking stick, rod

tukak $^{1}$ nci barge

tukak $^{2}$ nch craftsman

tuku' ${ }^{1}$ nci hearthstone

tuku $^{2}$ vact bend (at joint)

tulac avt second day after tomorrow

tulak nci bone

tulak hataq bundle of roofing

tulak pala skull

tulak rusoq rib

tulaq vact push, hand over (possessions)

tulëh vact write; (me)nulëh, penulëh

tuli vaj deaf

tulok vact help; (me)nulok, bertulok

tumäq nci heel

tumoh vaci sprout; bertumoh

tumoq vact punch

tumolöc nca fish used for bait

tuna $^{1}$ vact connect, attach (one boat to another for towing)

tuna $^{2}$ nca eel (salt water)

tunang nch fiancee; bertunang 
tunas nci sprout, shoot

tungan nch only child

tunging vaci lie on face (with knees drawn up)

tungon nci tree stump, offering to spirit of rice

tungu vact guard, wait; bertungu

tungu lihac vact oversee

tunoq vac bend over, bow down before; (me)nunoq

tunu vact burn, burn up, heat with open flame

tunu hatu cremate a corpse

tunyoq vact point

tupah vaci overflow, spill

tupak vact take advantage of, stay or travel with; (me)nupak

tupay nca squirrel

tupay tanah ground squirrel

tupön nci piece of wood or metal used to clean the ear

tupon vaj blunt

tupoq $n c i$ village, locality pala tupoq village leader(s)

tupoq yuban Ko' Sireh village, Phuket tupoq lama home town urak tupoq villagers

turoc vact follow; (me)nuroc, berturoc turot vac descend; (me)nurot, berturot turot-menurot descending, descendants

tutoh vaci fall (of rain)

tutoq vact pound; see jelöq and padi menutoq padi pound rice halu tutoq padi pestle for pounding rice

tutot vact clasp, lead (by holding upper arm)

tuwah nab luck

tuwas nci artificial reef (to attract fish)

tuwin vact lever

\section{$\mathbf{U}$}

u exc exclamation

ubac nci medicine; brubac, berubac sumäq ubac medicine eaten with betel nut

ubac gurah laxative

ubac jawa tobacco

ubac pelita käkëp torch batteries

ubac tuna poison for killing fish

ubah vact move; berubah

ubat $n c i$ grey hairs

ucaq $v s p$ scold, declare

udoh vaj ugly, untidy

ugay vact fix, remove, take off (clothes)

ujak nch little boy (voc.), man's name

ujok $n c i$ end, cape

pulaw ujok island near Raya Island, Phuket province

ujok jalat end of the road

ujok terbët datoq name of a cape

ujok petok village on Peepee Island,

Krabi province

ukël vact pierce, drill hole, bore

ukol vact measure (distance)

ulä vact dribble, stick out tongue

ulak avt frequently

ulal nca snake

ulal caqcik intestinal worms

ulal tedok senoq cobra

ulik vact lever along (a heavy article)

umac $n c h O$ man

umac-mehamac nch $M$ mankind

umac-mesiya $n c h$ mankind

umaq $n c i$ wave

umaq galoq-galoq waves rolling high

umaq memecah waves breaking

umöl $n c i$ age

habih umöl die

umu vact suck (in mouth) 
ungäh avt frequently

ungäh-ungäh $a v m$ repeatedly

unol vaci retreat, reverse, withdraw

nol-unol withdrawing

unyoq vact distribute

upac $v s p$ slander

upah vact hire (a person)

rega upah daily wage

upat $n c i$ bait

upat patay sand worm

upay $v s p$ deceive; me.upay

upoh vact draw (water, from well)

urä vact pour out

urac $n c i$ sinews, threads, strength

ijën lima urac five-horse power engine semiya höy urac man with no strength

urac darah blood vessels

urak nch man, person who is not Urak Lawoi' urak berubac witchdoctor (white magic) urak bot man with merit urak krerja ayë angun butler urak krerja buwac roti baker urak maboq darah person who cannot bear to see blood urak makay sorcerer (black magic) (see appendix)

urak penyamun robber

urak penyuri thief

urak sal-besal great man, important man

urak salah criminal

us $n c i$ vapour, steam

usël vact chase

usiq vact play

usiq aba gamble

usiq ber play the lottery

usiq bertaroh play dice

usiq samoc play knucklebones

usiq supat play cards

usöc vact rub, stroke

usok vact carry (by two men on shoulders) usoq-asan origin; asan

utäq $n c a$ catfish (deep water)

utal nca camel

utöq vaci limp

utöq-utöq avm limping töq-utöq limping

utok $n c i$ profit

uy $n c i$ withe

uyäq nca cicada

W

wa $n c h$ uncle, aunt (older sibling of parent) see may, ma

wac $^{1}$ avt straightaway

wac $^{2}$ nci $T$ Buddhist temple

waling vact $E$ weld

waqtu $^{1} c s$ when

waqtu $^{2}$ nci time

bilak waqtu all the time

röc waqtu dah the time has come

waqtu ini now

waqtu itu then

waqtu malap at night

waw $n c i T$ kite

wayak $n c i$ theatre

wayak kulëq shadow play

wayak gelaq film show

wayak gelaq hidoq moving pictures

wayak gelaq mati still pictures, slides

wayak gelaq tegal still pictures, slides

wëq-berduwëq $n c i$ financial success; duwëq nya buwac wëq-berduwëq ler dëq kawat dëq tupoq $\mathrm{He}$ had financial success more than others in the village

withayuq $n c i T$ radio

woy exc exclamation of surprise 
$\mathbf{Y}$

ya res yes

yäq $n c h$ grandmother

yakal $n c i$ root; see jakal

yak-layak nca swallow

yamöng $n c i$ torch; see jamöng

yanah nca kind of fish

yang $n c h$ great-grandparent (maternal, paternal)

yang-munyang $n c h$ ancestors yepun $n p p$ Japan; also nipun

yingkali $n c h T$ prostitute

yiplaq vaci gamble, cast lots

yiw npp Jew

yöm vaux $T$ willing to

yöm nyawa mati give himself to die

yu csf until, even till

yu-caq until that

yuban $n p l$ Laem Tukae village, Ko' Sireh, Phuket 


\section{ENGLISH - URAK LAWOI' FINDERLIST}

A

abandon tingan

abates kebah

abbreviate melaw panaq-panaq

abbreviated lakah-lakah

abdomen proc

ability biyas ${ }^{2}$

able to belëh ${ }^{2}$, berbelëh, biyas ${ }^{1}$, rasa

able to control rain panay mita hujat

about kira-kira

about to retaq 2

above atas

abstain from bertahat

abundant lebac

accompany atac, beratac

accomplished pesuc

according to bekaq

accordion regäng

accusation pasan kena adu

accuse $\operatorname{adu}^{1}$, tudoh $^{1}$

accustomed to biyasa

act as a mob grumöng

act in pretence sengaja

acting as a group phru

acting repeatedly buwac-berbuwac

acts perbuwac

Adam hadap, toq adap

Adam's apple bökbrök buwah hawa

Adang Island hadak ${ }^{1}$ add to tamah

addicted rasoq

addicted to lekac ${ }^{2}$

additive ragi

adhere berkraq

adhere to ngapö

admit sangoq

admit defeat bralah

adoptive father paq berhidoq

adorn metat

adulterer semiya berkasëh

aeroplane kapan trerbak

after lepas ${ }^{2}$

after that lepas itu

again lagi $^{2}$, lagi-lagi, pulak

age hadac, semay, umöl

agent pharaq

agree pakac

aim at tenöng

air angën

air compressor ijën angën

alight berkac

all rata, semuha

all the time bilak waqtu, srertak

allow bri $^{2}$

almost krertäq, macap naq, serpaq, srerpaq

also juga, lagi ${ }^{1}$, lagi ${ }^{2}$

altogether hapa ${ }^{1}$, semuha

always selalu 
amazed peläq-hati

amazement particle pah

amazing peläq

amputee kudok

ancestors bilakäl, ninëq, nyang-munyang, toq ninëq, yang-munyang

anchor berlaboh, sawoh

anchor ring paqanaq

anchorage pelaboh

ancient buran

ancient customs patak nutu

ancient times duhulu nutu

and jangan ${ }^{2}$

angle sagi

angle at bottom of prow of boat dagu

angry demiq-hati, musal, risaw-hati

animal benatak

ankle temuku

annoyed risaw, salah-hati

anoint pulëh

another matter selagu

answer tikah

answer back tikah parëq

ant semöc

ant mound temoq

anus butoc tahi

anyone sapa $^{2}$

anything apa, nama ${ }^{3}$

anything at all hapa ${ }^{2}$, nama jenäh, namanama

anywhere diha ${ }^{2}$

apply medicine berubac, brubac

approach mehadaq approach a superior siräq ${ }^{2}$

appropriate patoc

arch $\mathrm{koq}^{1}$

arched jawol

area nanggri, soq ${ }^{1}$

area around a house laman

areca nut pinang

argue tegah

argumentative mudah berlawat

arm lengan

armpit ketäq ${ }^{2}$

around kelilik ${ }^{1}$

arouse graq

arrange bercat, metat, petat

arrest rigaq

arrow bulus, prulu

artificial reef tuwas

as setana

as a group sekawat

as if bekaq caq, juju-caq, serupa kaq

as many as röc-kaq

as much as possible lëh-belëh, sebanyaqbanyaq

ascend nyanyäq

ashamed celäq

ashes habu

ask menanya

ask for mita

ask for a loan mita naq hutak

ask from each other mäng-ngemäng

ask unitedly sama-hati mita

aslant kiwëq 
assemble berkoq, brerkoq

astonished hirat

astray sesac

astrologer nujop

at dëq ${ }^{1}$, pada, pëq ${ }^{2}$

at all lagi ${ }^{2}$, lalu ${ }^{3}$

at enmity musal-musal

at fault salah ${ }^{2}$

at night waqtu malap

at the same time semën

at this time selama-ini

attach tuna ${ }^{1}$

attach to seläq

attached to lekac ${ }^{2}$

attempt to kuwasa

aunt may, wa

auspicious time ketika

avoid mengelaq, tiliq

awake dahani

aware of sedal

aware that sedal caq

axe kapaq

B

back belakak, blakak ${ }^{1}$

back and forth like a drunkard segiwak-segiwak

bad luck sisën

bad smell ba.u busoq

bag bäq ${ }^{1}$, thok, tipaq

baht bac

bail out tima bait upat

Bak Jok village near Takuapa kalan

baker urak krerja buwac roti

balance timang

ballast timang

balloon belumäq babi

bamboo buloh, nganyöq

bamboo shoots rebok, buloh petök

banana pisak

bang phoq

Bangkok bangköq

bangle gelak

barbecue dadak, salay

bargain tawal ${ }^{1}$

barge tukak ${ }^{1}$

bark gelap

bark (of dog) nyemuh

barnacle krachak

basin pasu

basket raga

bathe mani

bathed in perspiration kebaq

bat kelawal, laq.ulaq

bay teloq

be jadi ${ }^{1}$, ada $^{1}$

be able rasa ${ }^{2}$

be at ada $^{2}$

beach patay

beads gernëq, grernëq

beam tilat

bean kacak

bear bruwak 


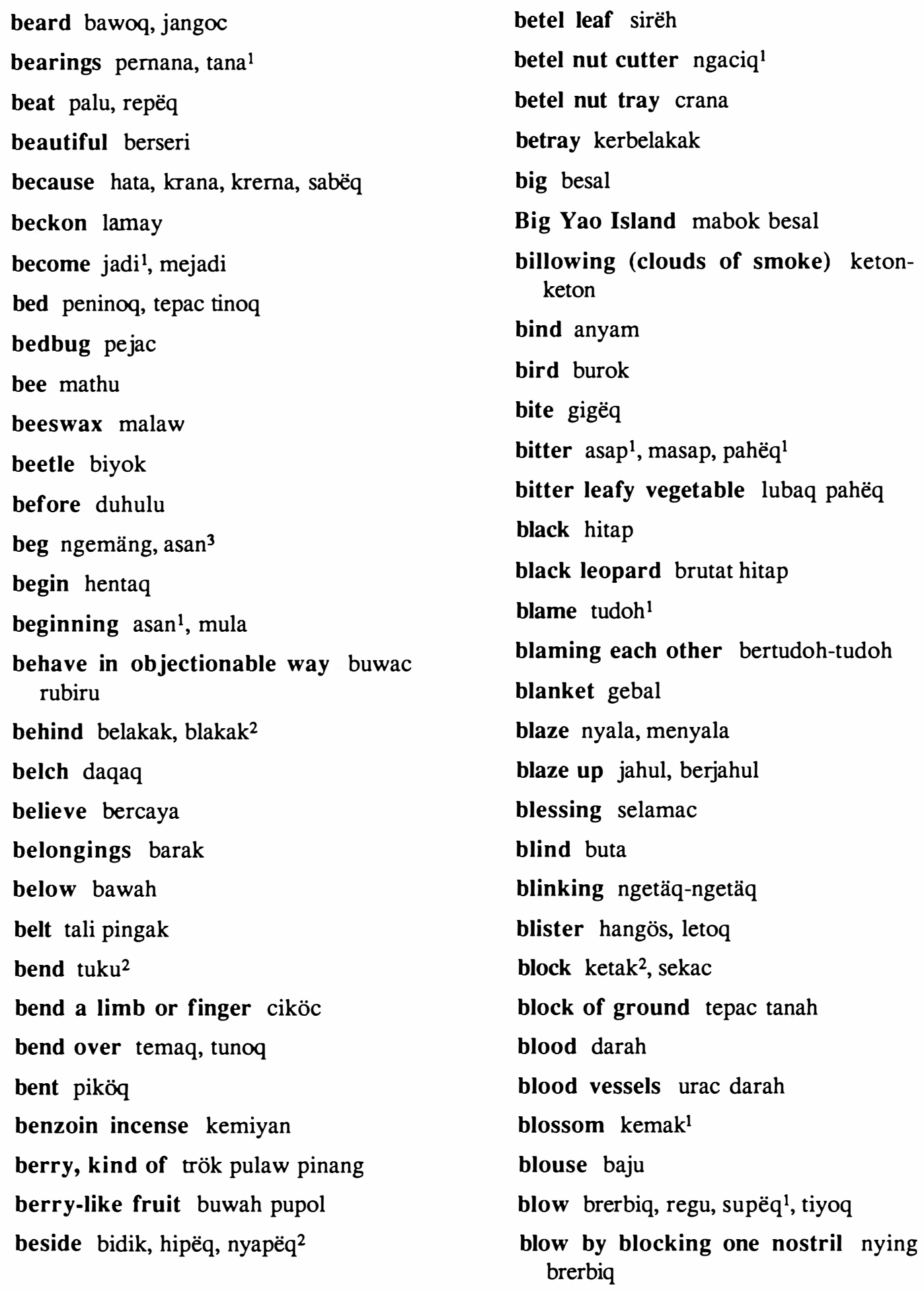
brerbiq 
blow on rumot

blow spirit away kepuh

blowpipe buloh menupëq

blue hijaw

blunt tupon

boast bertengan, menunyoq

boat prahu, jukök

boat built from zalacca palm prahu kumal

boat built of planks prahu timaw

boat for spirit festival prahu pelacak

boat of dugout type prahu lunas

body nyawa

body hair bulu

boil patët, rebus

boiling menidëh, nidëh

boiling water ayë menidëh

bold brani, beni-brani, hati beni brani

bone tulak

book surac

boom caciq layal

boom of a dredge tanga

bore ukël

bored jemu

boring for tin samples böräng

born berjadi

borrow minyap

bother kucay

bottle libuli

bounce renyas, tapih

boundary tekös

bow koq ${ }^{1}$, panah ${ }^{1}$ bow down temaq

bow down before tunoq, menunoq

bowl batën, makoq

box bäq ${ }^{1}$, peti

bracelet gelak

brackish cröy, kroh, masët

branch dahat, reba

brand gamal

bread roti

break lekap

break into pieces lepäq

break up berpecah

breakable (bamboo, wood) köq-kröq

breast dada

breathes menyawa

breathing bernyawa

bridal costume maqalac

bride cawsaw

bridegroom cawbaw

bridge jamat

bright saya

bring amët maräh, bawa, bawa maräh, bermaräh

bring together prerkoq

brinjal trök

broad lega

broken benasa, patah ${ }^{1}$, pecah

broom pengikay

bruised lekuq

brush ginyëh

brush off kipas

Bua Island paqtajay 
bubbles kemöq

bubbling up brernäh

Buddhist temple wac ${ }^{2}$

buffalo beetle biyok krerbaw

Buginese bugih

build a fire rumot api

bulging kebuk

bullet prulu

bundle of rice padi ikac padi

bundle of roofing tulak hataq

bunghole möngmöng, lubak möngmöng

buoy telapok

Burma awaq

Burmese awaq

Burmese priest sami awaq

burn pelos, tunu

burn up tunu

burning berapi

burnt pelah hangös, terpelos

burp daqaq

bury tanam

bury a corpse tanam hatu

bushy brerba

business duli, thuraq

but tapi

butler urak krerja ayë angun

butterfly marama

buttocks patac

button mengacik, pengacik

buy beli, meli

by own cleverness manay sediri

\section{C}

cake tepok

calf of leg betih

call belalok, berlalok, blalok

call a witchdoctor mawa

called seboc

calm sengaq, tedoh, tenang

calm water ayë sengaq

camel utal

candle dët

cannon senapak

cape ujok

capital tagat

capsize cerköq, karap

captain kaptat, pelima

care for bela, berbela

carry akëq, bawa, berakoc, brakoc, katäq

carry at side biming, kalëk

carry far melamok

carry in a fold kanok ${ }^{1}$

carry in arms nëk, riba

carry in the hands apu

carry on a pole kanal

carry on back cakös

carry on head junyok

carry on shoulder tangok, usok

carry out a vow berniyac, meniyac

carrying pole nganal

carsick maboq setri

carve täk

cashew nut jamu

cast riwak, tuhoq 


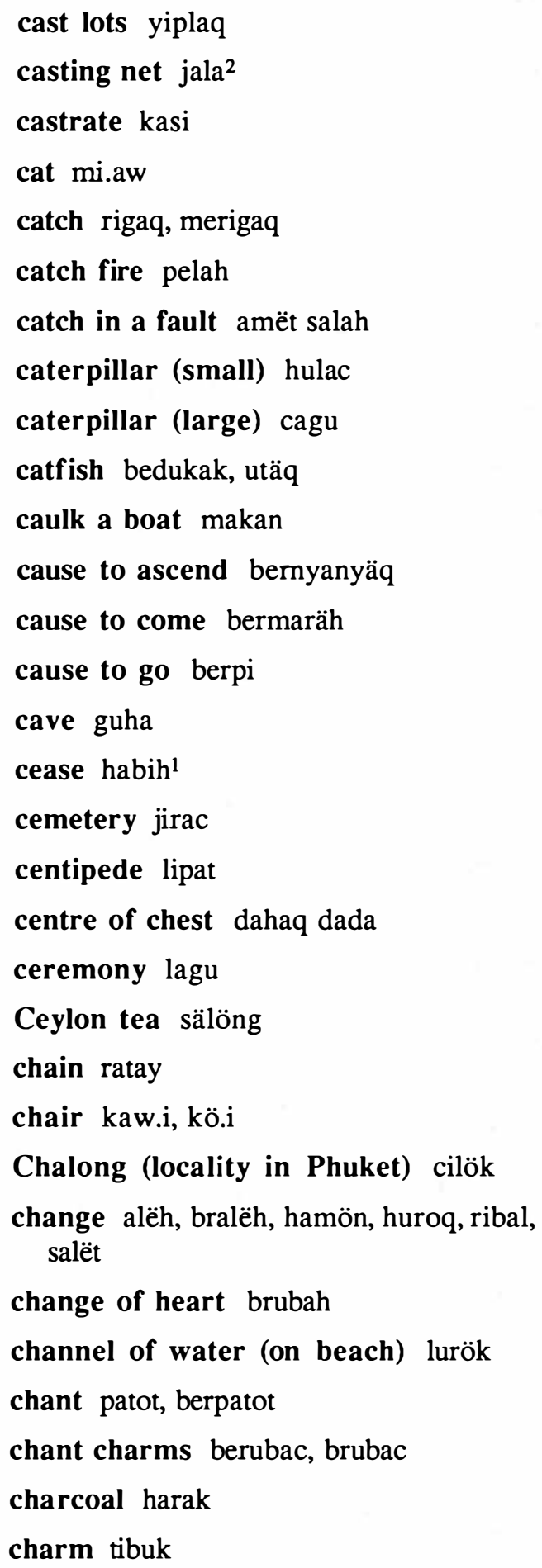

charm string takan

chase usël

cheap murah

cheek pipi

chest dahaq dada

chew pepaq

chew betel nut mengëp, ngëp

chickenpox capaq, huwac capaq

chief foundation post cawak seri

child nanaq

chilli sauce nachuq

chin dagu

China cina

Chinese chopper tamäq cina

Chinese temple toqkök

Chinese tin mine söpöng

chipped repëh

chisel pahac

chisel out tuboq

choke tekat, tergäq

choke on a fishbone khäq

choose pilëh

chop repoh

chop down tebak

chop up small cicak

chopper, Chinese tamäq cina

chopper, Thai tamäq siyap

Chumpon, South Thailand chumphön

church daw bermun

cicada uyäq

cigarette me.isaq ${ }^{2}$, möhun

circumcise krac kulë suläw 


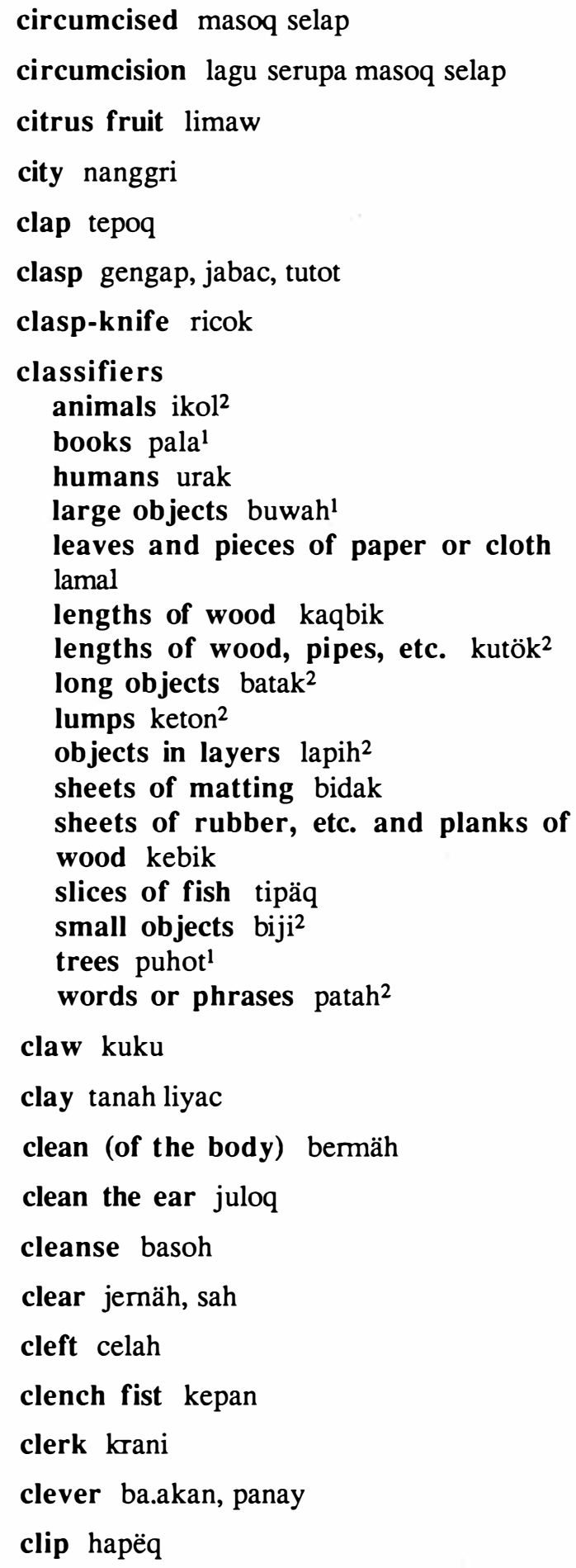

clock jap

close kapus, tapoq ${ }^{2}$

close by bidik-bidik, dapik-dapik

close friend kawat belëh bersama bajiq

close relations dibradi

close together rapac ${ }^{1}$

cloth kayët, guni kiyap

cloth wrapped around baby kayët pöcpöc

clothes kayët

cloud kemuwang

cloudy simöy-simöy

clutch gengap, ngapö

cluttered semaq

coarse kasal

coat baju

cobra tedok-senoq, ulal tedok senoq

cockroach lipas kelik

coconut kelamël

coconut husk hapas kelamël, sapoc kelamël

coconut meat teburok

coconut milk satat

coconut scraper mengaröc

coconut tree puhot kelamël

coconut, green kelamël hijaw

coconut, ripe kelamël masaq hitap

coconut, small and young kelamël mumak

coconut, young kelamël muda

coffee kopi

coil together likal, belikal

cold bejäq, huwac srema, serna, srerma 
collapse lepah, rutoh

collapsed kapä

collect kutëq, mengutëq, mungöc, ngitäq, pemun

collective action phakhac

collide belaga, blaga, ladok ${ }^{1}$, langal

colouring ragi

comb suray

combine prerkoq

Come! joh

come maräh, mari, bermaräh

come back parëq

come from datak

comfort mujoq, pujoq

command hukop, pesat, mesat, pemesat, permesat, suroh, menyuroh

commit adultery kasëh

commit suicide bunöh diri

committee men semiya berkira

compass keduman

compel perkat, prerkat ${ }^{1}$

complain memela

complete genaq, habih ${ }^{1}$

completed selesay

completed action habih ${ }^{3}$, $\operatorname{taroh}^{2}$

completely crah $^{2}$, habih ${ }^{2}$, hapa ${ }^{1}$

compound used as caulking lagala

conceive berproc, menganok, nganok

concern duli

concerned ngac-ingac

concerned about berhimac

confused cacaw

confusion kelacuq connect tuna ${ }^{1}$

conquer jenah ${ }^{1}$

consider ingac, bringac, beringac, menataq

considerate timang-hati

constantly rapac ${ }^{2}$

constipated kebusäq, kemuk

construct timaw ${ }^{2}$, nimaw

contact suwa

container thok

containing berisi

content senang-hati

contented senang

contents isi

contest sabok

continuously srertak

convey people or goods pedoq

convulsed ngetac, terngetac

convulvulus taroq kakok

cook bermasaq, tengaq

cooked masaq

cooked food eaten with rice lawoq

cooked rice nasi

cool bejäq

coral gudap, batu gudap

cord for drawing in fishing net sayman

core of a boil sön

cork tapoq ${ }^{1}$

corn jakok

corner berdahaq, cadok, sagi, siku

corpse badat, hatu, manyac

cotton benang nyahëq

cotton wool kapas 
cough batoq ${ }^{1}$

country nanggri, benuwa

coupled pegu

coupled together prakay

court san

court case daqwa

cover tudok

cover head with a blanket belumus

cover sin tudok dusa

cover the body tudok nyawa

covered with a skin disease berkuraq

covering lid tapoq penutok

covetous haluba

cow lemu

cowrie shell su-asu

crab ketap ${ }^{1}$

Crab Island merpu, mrerpu

crab trap pupang

crack open mengatöq

cracked retaq ${ }^{1}$

craftsman tukak ${ }^{2}$

cramped penöh kecac

crate kranyak

crave tagëh

crawl rakaq, merakaq

create berjadi

creep rakaq, merakaq

creeper with small berries teringi

crevice prerlök

criminal urak salah

criticise ajök, mejah

crocodile bahaya crooked kiwëq

cross kayu plitak

cross over jrermak

crossbeam tras

crossed belitak, plitak

crossroads cipak tiga

crow burok ak.ak, denak, burok denak, muköq, memuköq

crow pheasant burok cepelik

crowbar tangcaw

crowded kercac, krercac, ramay

crown cubuk, kecubuk

crown of the head semengac dëq pala

crucifix kayu plitak

crunchy köq-kröq

crush pinyäq

crush underfoot ginyëh

crushed halus

cry menangäh

cry of pain or distress ados

cry out sengaraq

cry-baby nanaq bay

cry together menangäh raquq

cubit tök

cucumber timön

cummin kunyäq

cup cöq

curly jerikan

current dras ${ }^{2}$

curry gulay

curse abol, asan ${ }^{2}$, bermalu, kimaq, maki, malu, supah

cursed celaka 


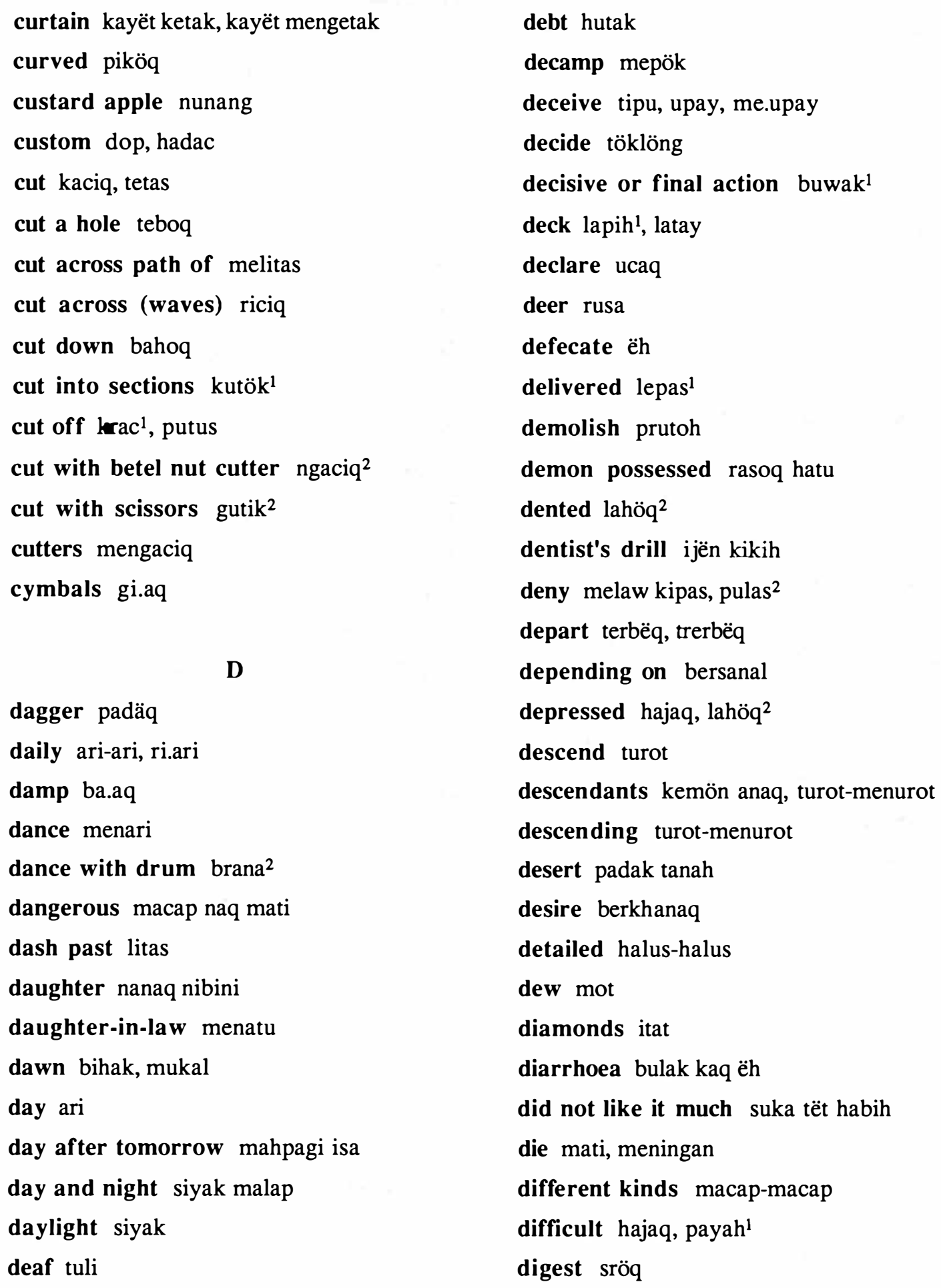




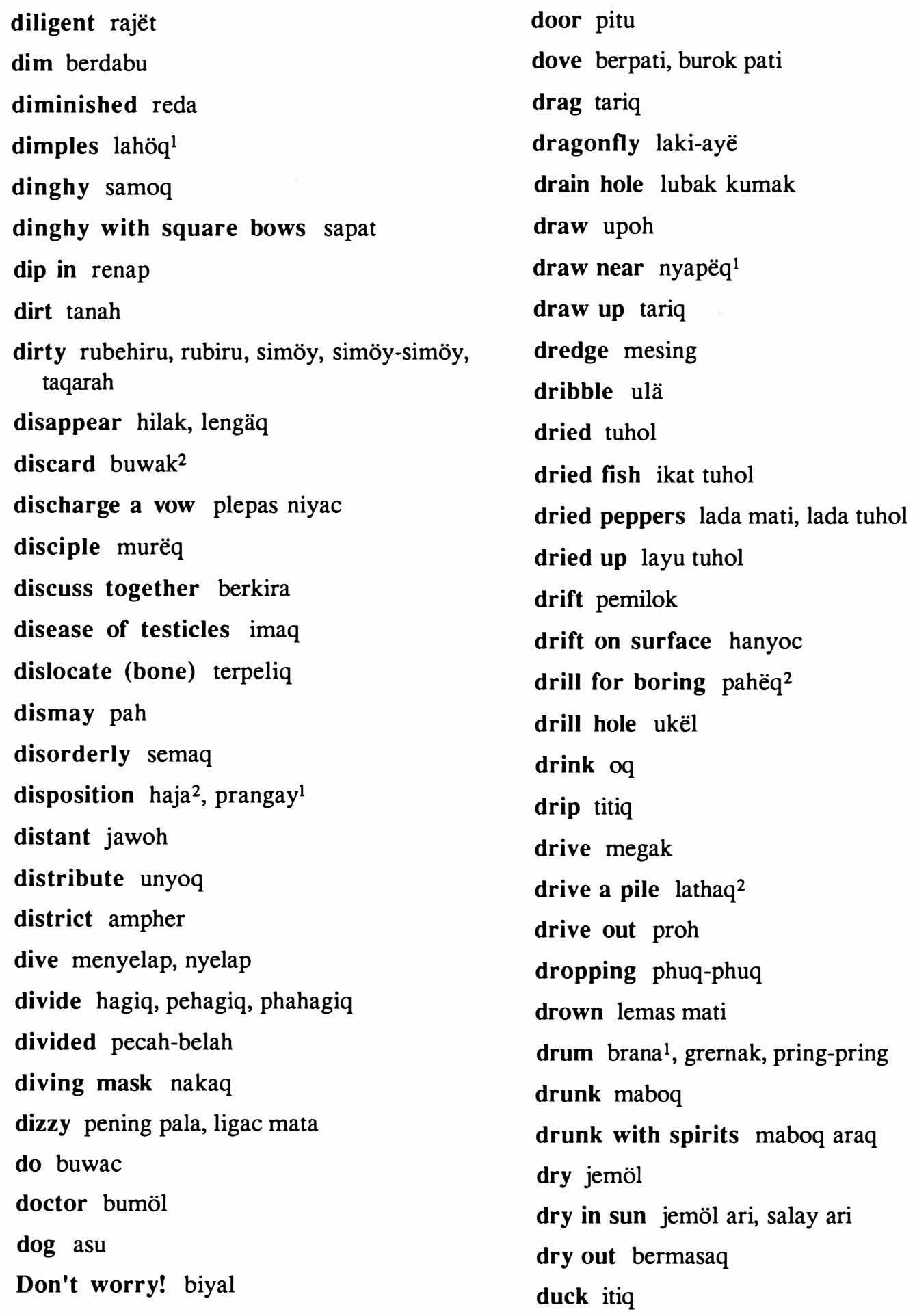




\author{
dull redop \\ dumb and simple berbelah \\ dung tahi \\ dust habu \\ dynamite böm
}

$\mathbf{E}$

each sok

each one sik-masik

eagle helak, lak

ear takay, telinga

earlier nitay

early evening henya

earrings subak ${ }^{2}$

ears of rice takay padi

earthen ricepot belanga tanah

earthquake tanah bringöq

easily mudah

east timöl

easy mudah

eat makat

eat together senasi

echo bertihac

eel beloc, tuna ${ }^{2}$

egg telol

eggplant trök

eight lapat

eighteen lapat-belas

eighty lapat-puloh

elbow siku

eldest sulok

electric powerline tali api röntri electricity röntri

elephant gajah

elephant beetle biyok gajah

eleven sebelas

elliptical bulac panyak

embrace bernäk

embrace neck labat

emphasizer $e r^{2}$, ler

employees anaq buwah

end ujok

endure lawat

enemy setru

engaged bertunang

engine ijën

engine cover nakaq

enquire tanya, menanya

enter masoq

enter Islam masoq selap

entrance to fish trap pala bubu

entrust to benal, kirip

epidemic hawal ${ }^{2}$, hawal penyakëq

equally sebaya

erase isuc

erect akëq

erratic hati cacaw

Eve hawa

even if misël-caq

even though misël

even till yu

evening paqsenya

evening star phrerlap

ever since taqdëq 
every bilak, rata

every day bilak ari, ari-ari

everywhere rata-rata

evil behaviour barak tët guna

evil heart hati hitap

evil spirit hatu

examine sasac

excavate sudöq

exceed melebëh

exceeding many banyaq terlalu

exceedingly terlalu

exchange huroq, ribal

excrement tahi

exert oneself nulëk

exhaust pipe blumok, lubak pahëq

exist ada $^{2}$

expensive mahan

expert berguru

expose jemöl

extend hubok

extra payment (for steersman) tikök

extravagantly rahura

extreme pain sakëq bisa

extremely amac

eye mata

eye of a needle lubak jarop

eyebrow gengëp

\section{F}

face mukha

faint selaq

faithful remak $^{1}$ fall gugol, suroc, tutoh

fall down lepah

fall over rebah

falling tide ayë suroc

fan pengipas

fare tamak

fashion rupa $^{1}$

fasten on berkraq

fat lemaq

father apok, $\mathrm{paq}^{1}$

father-in-law paq metuha

fault salah ${ }^{1}$

fear takoc, menakoc

fearful penakoc

feast li.ang, makat li.ang

feathers bulu

feel brasa, rasa

feel cool berbejäq

feel faint or weak remay

feel sorry for menyesan

female aya

female genitals butoc, isak berdarah, isëq

fence pagal

fever huwac

fiancée tunang

field padak

fight belaga, berprak

fight against lawat

fighting cock hayap sabok

fill in tamot

filling iti

financial success wëq-berduwëq 
fine halus, pepu

finely halus-halus

fingerprint bekas jari

finish suc ${ }^{1}$, sudah ${ }^{1}$, sudah $^{2}$

finished pesuc, sudah ${ }^{3}$

finished action suc $^{2}$

fire api

fire heap lungoq api

first lamula ${ }^{1}$

first glimmer of dawn tana berbihak

fish ikat

fish market pajaq ikat

fishpaste blacat

fish scales sisiq

fish spear tiroq

fish trap bubu

fish used for bait tumulöc

fish with a line mengayën

fish with a net mukac, menyala

fish with large hook menyekaq

fish with rod nyuwang

fish without scales ikat licöt

fish, kind of baqbuq karak, ikat mehumoc, mamöng, talak, trubuq, yanah

fishing line tali kayën

fishy smell hanyä

fitting padat

five lima

five minutes of time lurök

fix ugay

flag kenira

flame nyala, bernyala, penyala flaming anger pehangac-hati

flash läq ${ }^{1}$

flashing berngaw-berngaw

flat paya

flat place tepac rata

flatter me.oc

flesh lulu

flick prerciq, tuju

flick finger with other hand petiq

fling riwak

float hanyöc, melayak, telapok, timon

flood apoh

floor pelatal, latay

flour tepok

flow in quantity ruru

flow out nilëh, menilëh

flower bunga

fluent pahap

fly trerbak, melayak

flying ants terubuk, trubuk

fold lipac

follow ikoc, turoc

follow a roundabout course meneloq

follow own choice manay taqasik

fontanelle bubot

food barak makat, nasi

food prepared as an offering hidak

football buwah gula

footprint bekas kaki

for bida $^{1}$, naq $^{3}$

for a long time lama-lama

for ever manyak-röc, musët-musët 
forbid larak, berlarak, blarak

forbidden patak

forever semanyak-röc

forge into ranoq

forge through undergrowth manoq

forget lupa

forget oneself lepa

forgive apot

forked support used in boats sanga

former lama

fortunate bertuwah

fortune-teller bumöl lihac groh

forty pac-puloh

foundation berjakal

four pac ${ }^{1}$

four-sided pac sagi

fourteen pac-belas

fowl hayap

free lepas ${ }^{1}$, melepas

freed from lepas dëq

frequently ulak

fresh tawal ${ }^{2}$

fresh peppers lada hidoq

freshwater reed riyok

friend sabac

frog bekataq

from pëq ${ }^{2}$, pada

front helöt

fruit buwah ${ }^{2}$

fruit, kind of buwah sipol, sening

fry renak

frying ladle senoq besi fryingpan belanga, belanga besi, blanga

fulfilled remak $^{1}$

full penöh, penöh kecac

fully cooked puwah

fun ramay

fun together beramay, bramay

funnel blumok, bumok

fur bulu

furious isët

further pulak

G

gamble usiq aba, yiplaq

gape open nganga

gasp lisoh

gasping for breath menyawa sepuc-sepuc

gather pungöc, mengutëq, mungöc

gaze tinyung

gearwheel besi giya

germ inok

get belëh ${ }^{1}$, mebelëh

get on nyanyäq

gibbon maqwa

gills isak

ginger liya

give $b^{1}{ }^{1}$, hagiq

give birth to melepas

give food to bermakat

give freely halay

give birth branaq

glutinous rice with cummin puloc kunyäq 
go pi, pergi

go against cangah, menyangah

go back berbaliq

go far lamok

go in groups begupok

go to windward bitas

go together bersama

go underneath nyuroq

goat bäq ${ }^{2}$

gobble sutoq

gobble up sulap

God tuhat, tuhat besal, tuhat besal dëq atas, tuhat dëq atas, lahtala

gold mas

good bajiq

good deeds phahala

good housekeeper berprangay

good-hearted bajiq-hati

goods barak, sebarak

goods of all kinds bena barak

goose itiq jawa

gorge sungay batu

government luwak

Government health clinic anamay

gradually pelat, pelat-pelat

grandfather cä

grandmother yäq

grape angun

grasping rapas, berapas

grass rupoc

grave lubak

great besal, sal-besal great man urak sal-besal

great-grandparent inyang, ninäq, nyang, yang

great-great-grandparent munyang

greater lebëh

greedy haluba

green hijaw

green vegetable, type of bucoq lubaq

greet angoq, menga

grey hairs ubat

groan merayu

grope raba, meraba

ground tanah, bumi

ground squirrel tupay tanah

group palah, pasoq

group of four sepac

grow old besal maräh

growing bigger lökbelök

growl meriyan

grown up besal dah

guard jaga, mejaga, tungu

gun senapak

gunpowder tanah piyoq api

guy-ropes temirak

H

habitually biyasa, jenah ${ }^{2}$

habitually, by practice or nature ladac

hack repoh

hadji haji, toq $\mathrm{ji}$

hadji's head covering srerbat, srerban

hadji's white headdress kepiyah 
Hai Island phrengay

hail hujat batu

hair boq ${ }^{1}$

hair-slide pehapëq sisë

hair bun sangon

hairpin to fasten bun cucoq sangon

half setengah ${ }^{2}$

half-cooked matah

hammer caulking between the planks pakan

hammock ayut

hand tangan

hand over tulaq

handcuffs gari

handle (of broom, etc.) hulu

handsome begacaq

hang gatok

hang on sakoc

hanging down sugël

happen jadi $^{2}$

happily ramay-ramay

happy senang, suka-hati

happy disposition hati bajiq

hard kras

hard-hearted hati kras

harpoon löl

has, have $\mathrm{ada}^{2}$

hasty gupol

hat moq

hatch merap

hate bechi

haul sitaq haul in mengilas

have ada $^{2}$

have convulsions ngetal

have not höy

have power over hukop

have room gaq

have to gadoh $^{2}$

having a child bernanaq

having young beranaq

hawk helak, helak pi.api, lak

hawksbill turtle karah

he nya

head pala ${ }^{2}$, kepala

head of penis nyuloh

headache sakëq pala, sengan pala

headman phunyay

heal bela, berbela

healed lega, semoh

heap lungoq

hear dengal

heart hati

heart beating irregularly ketuh-ketuh

heart not zealous hati tët tuhëq

hearthstone tuku ${ }^{1}$

heat with open flame tunu

heated up pehangac

heaven langäq

heavy brac

heavy kitchen chopper tamäq

hedgehog lanaq

heel tumäq

hell neraka, nöraka 
helm kemudi

help tulok, bertulok, menulok, nulok

helping one another bertulok-tulok

here kiyat, daw ini

hermit sami hutat

Hey Island, near Phuket laqäw

hide brulak, buni, linöng, seluni

hiding place tepac linöng

high tingi

high tide ayë penöh

hill bukëq

hip paha

hire siwa, upah

hit katöq, langal, mengatöq

hoarse garaw

hoe cakon

hold hapëq, junyok, pegak

hold between thumb and finger cikaq

holding gak-pegak

hole lubak, prerlök

hole for draining boat lubak pusac prahu

holed kemus, tirih

holy basil biji selasë

Honda engine hönda

hook caköq, kayëq

hooked stick penyaköq

hope cadak, haraq

horizontal supports inside boat sita

horn siyok

horn of animal tanoq

hornbill klakhëk

horse kuda hospital rongyaban

hot hangac

hot, peppery pedas

hotel rongräm

hour jap, pukol

house rumah

house lizard caqcaq

housefly langaw

how? kaqhami ${ }^{1}$

how many? brapa ${ }^{1}$

however tapi-caq

however it may be hami-kaqhami

howl alu

hull lukak

hundred ratus

hungry lapal

hurl riwak

hurriedly gangu

husband laki

husked rice beras

husks sapoc ${ }^{2}$

I

I ku, aku

ice ayë batu

idea manay

idol brala

if $\mathrm{adu}^{2}, \mathrm{kala}^{1}$, kalaw, $\mathrm{kaq}^{2}$

igniting plikac

ignore lepa

illness penyakëq

image gamal 
immediately datdat

immerse selap

impetuous gupol

implore asan $^{3}$

important sal-besal

important man urak sal-besal

impression bekas ${ }^{1}$

improving (health) lega

improvised wheeled toy lok-lok

in atas, dalap ${ }^{1}$

in a moment käq-lagi, kelagi, sac-sac

in a state of $\mathrm{ada}^{3}$

in debt terhutak

in sections setenös, tenös-tenös

in the beginning mula-mula

in the middle tengah-tengah

in the morning crah pagi, gipagi

In the name of Allah bisemilah

in the process of tengah ${ }^{3}$, tengah naq

in time dat

in vain böplaw

in whatever way kaqhami ${ }^{2}$

in-law ipay, metuha

inboard engine ijën tengaq

incantations ayë lemu

incanting baca ayë lemu

incite acop, beracop

increase bertamah

increasing dras ${ }^{1}$

Indian moneylender cëti

indications pernana

industrious rajët inefficient sepuc

inept sepuc

infected berinok, meli.aw ${ }^{1}$

inform bitahu

infrequent jarak

ingredients kelekaq

inheritance pesaka

inner meaning isi

inscribe tikäq ${ }^{1}$

insect lipas

insert cacaq

inside pëq dalap

inspect sasac

install pasak ${ }^{2}$

instead of gati

intelligent akan, berakan

intend to khanaq ${ }^{2}$

intercept bitas

interest on a loan bunga

interjection anu

intermittent bursts panaq-panaq

internal organs kelekaq dalap, lipa

internal upright in house cawak gatok

intervene sagak

intestinal parasites caqcik, ulal caqcik

invade (undergrowth, etc.) bermöq

invitation to act böh ${ }^{2}$

invite ajaq, ba.ajaq, berajaq

invulnerable megah

iron besi, timah, ayën

is, are ada $^{1}$

island pulaw 
island in Burma tenak

island near Renong pingay

island near Surin Island meriyap

island south of Surin Island keladi

Isn't it true? bukat ger

issue out of terbëq, trerbëq

it nya

Italy itali

itch gatan, penyengac

itching with skin disease berkudën

itchy skin disease kudën buta

\section{$\mathbf{J}$}

jail pejara

Japan nipon, yepun

jar kaca

jealous deki, kemuru, sakëq-hati

jellyfish with sting pay-apay

jellyfish wound baloh

jerk a fishing line ayaq

Jew yiw

jewellery barak matay

joint tenös

joist prös

Jum Island, Krabi kecap

jump lupac

jump down terjot, trerjot

jungle hutat

jungle knife parak

junior Buddhist monk nën

junk sagol

just läh just a little dikiq-dikiq, koq kiqdikiq, sabrasa

just as $\operatorname{tana}^{2}$

just like macap bekaq

just now singi ${ }^{1}$

just then tana-bajiq

jute joc, jut, ramin

Kaew Island, Phuket province panat

kapok kabu

keel of boat lunas

keel over cehäq

keeping festival beramay

key anaq kuci

kick ngutal, sipaq

kick with sole of foot sipaq sila, terajak

kill bunöh

kilogramme kilo

kind jenäh, macap, rupa ${ }^{1}$

kindle lekac $^{1}$, rumot

king raja

kiss ciyop

kite waw, lak, helak

knee lutoc

knife pisaw

knock kethöq

knock down prutoh

know tahu

knuckle buku 
Krabi town kerbi, krerbi

kris krih

$\mathbf{L}$

labourer kuli

lacking putus

ladder tanga

lady siti

Lady Eve siti hawa

Laem Tukae village, Ko' Sireh, Phuket yuban

lake kubak, lunak

lalang grass lalak

lame capëq

lamp pelita

landowner tuhat tanah

language basa

Lanta Island, Krabi province satak

large besal

large pond lömong

large waves gelumak

large weight ladok $^{2}$

lash sirac

last busu, penyudah

last night malap senya

lasting tegoh

lasting until daylight bersiyak

late afternoon senya

later blakak itu

laugh gelaq, bergelaq

laxative ubac gurah

lay down letak layer lapih ${ }^{1}$

lazy segat, menyegat, penyegat

lead cutot, irëq, tutot

lead in procession hä

leader kepala

leader of manohra group pala balay nora

leaf dawot

leaf cigarette pe.isaq, pi.isaq

leaf roof hataq

leaking tirih

lean kurus

lean against sidöq

lean on sanal, bersanal

leap melupac

leap on segoq

learn blajal

learned berguru

leave tingan

leech litah

left behind bekas ${ }^{2}$

left side kiri

leftover bekas ${ }^{2}$

lengthen hubok

leopard brutat basa tebaw, brutat bitik

leprosy penyakëq rubehiru

lessen kurak $^{2}$

let $\mathrm{bri}^{2}, \mathrm{bri}^{3}$

let go rönya, biyal

letter surac

level baya

lever tuwin

lever along ulik 
lice gutu

lick jilac

lid tapoq ${ }^{1}$

lie me.upay

lie down guläk, tinoq

lie face up terletak

lie on face tunging

lie prostrate terguläk

lifelong se.umöl

lift akëq, berakëq, berakoc, junyok

lift up akoc

light crah $^{1}$, cucoh, rihan, siyak

light a fire belekac api, rumot api

light in colour muda

lightning kilac

like bekaq, rupa $^{2}$, serupa, suka ${ }^{1}$

like that kaqgiter ${ }^{2}$

like this kaqgini²

like to suka ${ }^{2}$

lime kapol, kapol mirah

limes limaw nachuq, asap limaw nipih

limp utöq

limping capëq-capëq, töq-utöq, utöq-utöq

limpingly tëq-jetëq

line hac

linen ramin

lion singa

lips bibël

listen ningay, meningay

little demiq, dumiq, demiq-demiq

little at a time sekali dikiq

little boy ujak little girl iya

live hidoq

live together hibot

liver hati

living berhidoq

living expenses belanya

lobster hurak

lobster-spear ipak

local midwife bidat

locality lirah, tupoq

location at or beside soq $^{2}$

lock kuci

locket agöq

Lone Island (near Phuket) telul

long lama, panyak

long bean kacak panyak

long lengths berkutök-kutök

long outer garments baju koc

long robe lapoh

long-legged waterbird rangok

long-tailed monkey kra

look askance jelik

look at lihac, jengöq, menyengöq

look away from jelik

look for miya

look for lice silaq

look sideways nyapëq ${ }^{1}$

look straight ahead tinyung remak

look up langoh

looking lac-lac

looking around berlihac-lac

lop of $f$ cicak 
Lord Buddha kedemay

lorry nori

lose hilak

lottery ticket ber

lotus flower buwah telipoq

love sayak

love illicitly kasëh

low renah

low tide ayë krik

lower abu

lower into water jala ${ }^{1}$

lower leg betih

lowering (a person) berturot

luck tuwah, bertuwah

lump keton ${ }^{1}$

lung söq

\section{$\mathbf{M}$}

mad gila

magnet besi brani

maimed kudok

make buwac, berbuwac, berjadi

make merit tabot, tehabot

make sea trip ngenyah

make threatening gesture angaq

making sounds of distress ba.ados, berados

malaria huwac ketal

Malay dollar ringëq

Malay-type dance rungëk

Malaya melaya, melayu

male kilaki male animal bapa

man kilaki, semiya, umac, urak

man like us semiya kaq kita

man with merit urak bot

mango maqplap

manifest plihac

mankind mesiya, umac-mehamac

manners basa

manohra dance nora

manohra dance variant nora miyok

manta ray ikat pari sengac

many banyaq, parah

many fruit on tree buwah lebac

Maprau Island, Phuket sadap

marijuana ganya

marine growth on hull of vessel lumöc

marine growth, decorative akal bahal

marine worm temiloq

mark tana ${ }^{1}$

mark of rank mrerka

married bernikah

married couple laki-bini

marry nikah, menikah

marrow, kind of gunol

massage kepiq

Malay state of Kedah kedah

mast tihak

mast of ship tihak kapan

master nay, tu.at

mat roofing semak kajak

mat sail semak layal

mat, sleeping lepac 


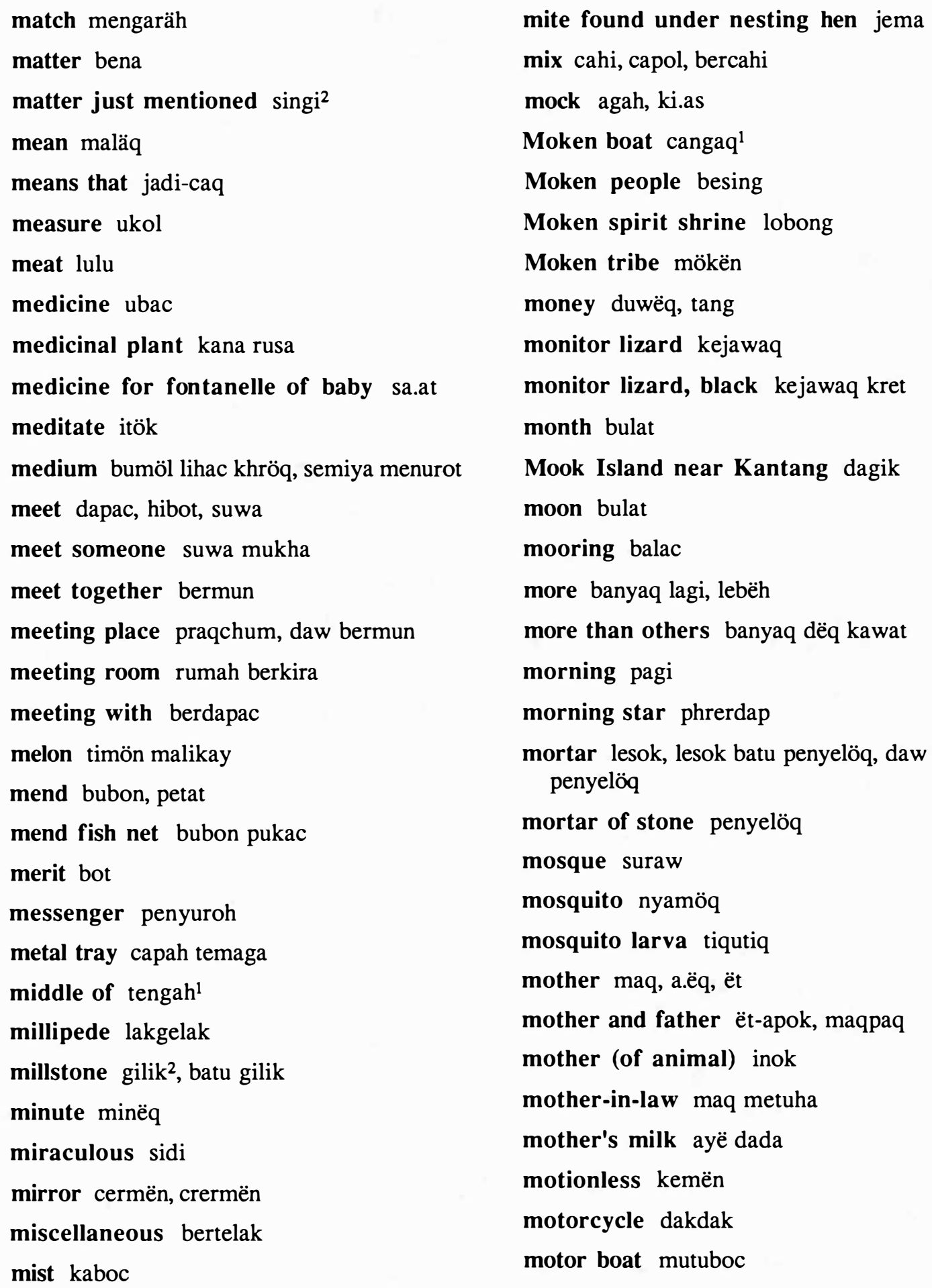


mountain bukëq, gunöng

mourn patot, berpatot

mouse tikus

mouse deer planoq, pelanoq

moustache misay

mouth muloc

move brakëq, ganyaq, isäk, ubah

move along isäk dikiq

move fast lajaq

move from place to place cäqbiräq

move on rollers galak

moving berganyaq, berubah

Mt. Jerai, near Penang jeray

much banyaq, banyaq-banyaq, brapa ${ }^{2}$

mud buhol

muddy lecah, lupol

murky kroh

murmur memela

Muslim expletive toq ${ }^{3}$

Muslim elder toq ${ }^{2}$

Muslim gifts to the poor sedekah

Muslim imam lebay, toqsäq

Muslim skull cap topi

Muslim time of prayer semayak

must gadoh ${ }^{2}$, gagah ${ }^{2}$, kena $^{2}$

mythical giant rahu

\section{$\mathbf{N}$}

nail kacik, kuku, sipaku

naked telanyak

name nama ${ }^{1}$

name of locality in Phuket town pekat named bernama, ternama

narrow sepäq

nationality baksa

nature haja ${ }^{2}$, isi, prangay ${ }^{2}$

naughty batah

navel pusac

neap tide ayë mati

near dapik

neck lihël

need berkhanaq

needle jarop

nephew kemön

nest sarak

net jala, pukac

net fisherman semiya penyala

Never mind! rönya

new baru ${ }^{1}$

nibble mengetën

nice smell ra.op

niece kemön

night malap

nine semilat

no bukat, höy, tët

nod angoq

noggin legeta

noise bungi

noisy buriq, raquq ${ }^{1}$

north tara

North Star bitak bata yay

nose hidok

not long enough sikac

not want timaw 1 
not wishing to tergamaq

not höy, tët

novice nën

now ini ${ }^{2}$, waqtu ini

numb kebas

number namber

nurse riba

nut kacak

nuzzle sumak

\section{O}

oar awac

obey menyaga, meningay

objectionable rubehiru, rubiru, taqarah

observe menyaga, mesoq

observe food restrictions berpatak

obstinate kras-hati, tegal-hati

obstruct sekac

obstruction in urethra penyakëq karak

obtain belëh ${ }^{1}$

ocean arök

octopus kraway

oedema basan

of naq ${ }^{1}$, dëq $^{2}$

offended demiq-hati, tedus-hati

offer to semah

offering to spirit of rice tungon

officer nayröy

official raja

offspring benäh

often sac-sac

oil minyaq okay joh

old tuha

old and young tuha muda

old sailing vessel sekuna

olden times nutu

older sibling kaka, ca

olive kedunot

on atas, pëq ${ }^{2}$

on the contrary bukat

on their behalf bri ${ }^{5}$

once bersatu, sekali

one $\mathrm{sa}^{1}, \mathrm{saq}^{1}$, satu, se-

one body sebuwah

one by one sasa

one day se.ari

one handful segengap

one hundred seratus

one of each soksa

one pair segu

one person se.urak

one place setepac

one portion sekrac

one side sebelah

one thousand seribu

one tinful secalok

oneself nyawa taqasik, taqasik

only läh, sa ${ }^{2}$, saja

only child tungan, nanaq tungan

only one nähsa

open buka

open eyes nyelak

open out a dugout hull buka lukak 
open sea arök

operate on belah ${ }^{1}$

opium janu

opportunity celah, prerlök, tadah

oppose lawat, berlawat, blawat

opposite remak ${ }^{2}$

oppress kepiq, tekat

or ger $^{2}$

orange asap limaw manëh

orange drink ayë asap

order pesat

orderly berprangay

organ munën

origin asan $^{1}$, berjakal, usoq-asan

original lamula ${ }^{1}$

originally lamula ${ }^{2}$

other asik

other side serbak, srerbak

outboard engine ijën tuwin

outside luwal

outstanding seri, berseri

over there ho, hu, kiyuh

overcast redop, simöy, bon-srerbon, dopredop

overflow tupah, puwaq

overloaded sarac

oversee tungu lihac

overtake ketaq

overturn crerköq

overwhelmed with fear hati phal-phal

owl burok hatu

owner tuhat owner of a house tuhat rumah

oyster teritëq

$\mathbf{P}$

paddle kayoh, mengayoh, ngayoh, pengayoh

pain bisa

pain of infected wound sakëq bisa

painkiller thancay

paint cac, nyapak, sapak

pair begu, keduwa

paired pegu

palm of hand tapaq tangan, tapaq

pandanus palm frond kemuwak

pant lisoh

papaya timön kayu

paper kertas, krertas

paralysed kapä

parcel bukus

pardon maqah

park cöc

particle showing mild emphasis pot

particle, emphatic läq², lah, ler

particle, interrogative ger $^{1}$

particle, mild imperative nö, $\mathrm{sac}^{2}$

partnering berhun

pass melitas, menidas

pass between hills getik

pass by buwih, lalu ${ }^{1}$

pass by quickly litas

pass clear of helus

pass judgment krac hukop 
pass to another tötö

pass wind ketoc, kertoc

patch temporarily kecac

path jalat ${ }^{2}$

patterned cowrie shell su-asu bertelak

pawn gaday

pay bayal

payment rangwan

peaceful of heart senang-hati

peacock burok meraq, meraq

peaked roof prabok

pearl termika

peck patoq

Pee Pee Island, Krabi province bibri

peer at jengöq

peg pehapëq

pencil kalap

penis suläw

pension gaji buta

peppers lada

perch on ngatöc

perishing jahanam

Perlis state, Malaysia perlëh, prerlëh

permit benal

perplexed melengung

persist in prerkat $^{2}$

person who cannot bear to see blood urak maboq darah

person who is not Urak Lawoi' urak

perspiration macal

perspire peloh

pestle halu, hulu
Petburi city pëtburi

phial kaca

Phuket town tökkha

piano munën

pick julok

picture gamal

piece $\mathrm{krac}^{2}$, setipäq

piece of bamboo sidëq

piece of wood or metal used to clean the ear tupön

pierce temus, ukël

pig babi

pigeon burok mrerboq, burok tutru

pile lungoq

pillow batan

pinch cuwäq

pineapple nangnas

pipe pahëq ${ }^{2}$

pistol seton

pitch melagöt, menyangah

pity tercihat

place böh ${ }^{1}, \mathrm{pac}^{3}, \mathrm{pëq}^{1}$, $\operatorname{taroh}^{1}$, daw, tengaq, tepac $^{1}$

place in ship or boat medoq

place of the dead nanggri hatu

place where wood splintered kipaq

place with a shrine terbët

plait sipay

plane ketap ${ }^{2}$

plank papat

plank holed papat kemus

plant tanam

plant, kind of kelubi 
plastic bag thok plätik

plate jap, pirik

platform pelatal

platform for smoking or drying fish para

play usiq

play a violin gisäq

play cards usiq supat

play dice usiq bertaroh

play knucklebones usiq samoc

play the lottery usiq ber

playing about kerbetol

playing cards supat

pleased suka-hati

plentiful lebac

plough tegala

plug kecac

point tunyoq

poison nuba, racot, sengac ${ }^{1}$, tuba ${ }^{2}$

poison for killing fish ubac tuna

poisoned maboq

poisonous plant tuba ${ }^{1}$

poke eye jeluk

pole batak ${ }^{1}$, thak

police tamata

polite budi-basa

pomelo asap limaw hurak

pond kubak

pontoon panton

poor semekët

porcupine lanaq

porpoise maloma port tepët, terpët

possessed with evil spirit menupak, ngapö, rasoq

poultice ta.öq

pounce on srerkoq ${ }^{1}$

pound pathaq, jelöq, menutoq, tutoq

pound rice croh

pound (with knuckles) kethöq

pour on celöl

pour out urä

poverty-stricken hajaq

powerful kras, megah

practitioner of white magic bumöl berguru

praise me.oc, muji, puji

prawn hurak

pray bersawoc

pregnant berproc, kanok ${ }^{1}$, milëh

pregnant (animal) kathäk

prepare siyaq, bersiyaq, petat

presently jurus, sac $^{1}$, sejurus

preserve kelimac

press hapëq, tekat

pressed together kemat ${ }^{2}$

pretend haja ${ }^{1}$

pretty begacaq

price rega

priest sami

principle inok

proceeded to lalu ${ }^{4}$

productive lebac

profit utok

prohibit katak 


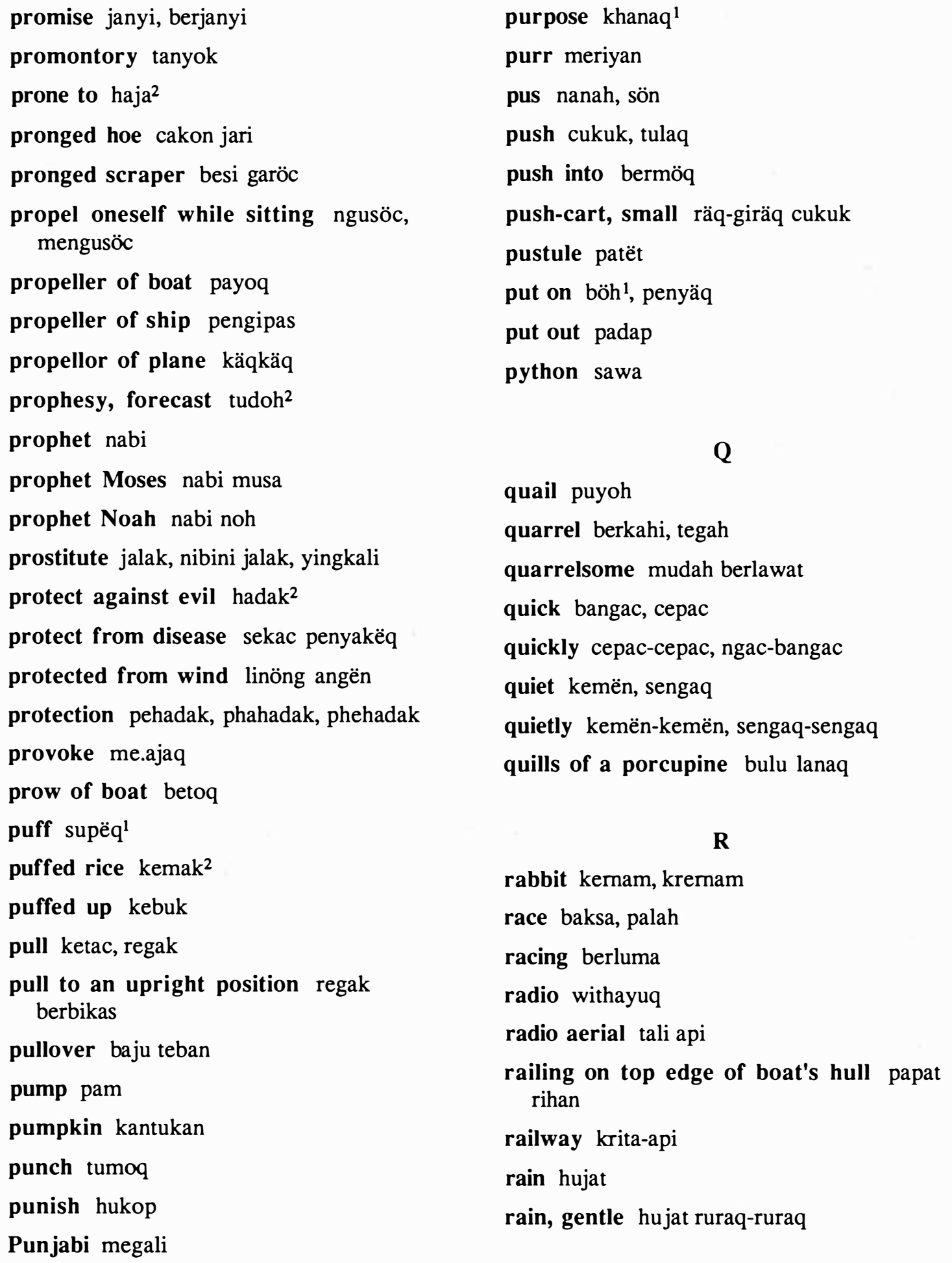


rain, sprinkling hujat pac-prac, ritih

rainbow layal hatu

raise a diver rethöc

raise up berbikas, bernyanyäq, pangöq

rambutan ramoc

ransom tebus

rat tikus

rattan huwi

Rawai village, Phuket raway

reach hadaq, melitak, röc

reach into seloq

reach out angaw, lejak

reached to reröc, saq ${ }^{2}$

reaching to röc-kaq

read baca

reap pungöc, giyo, ketap $^{3}$

reaped terketap

rebuke mejah

receive hamac, samoc, sangoq, bahamac, mehamac

recite baca

reckon ingac, kira

recognise krala

reconciled bajiq-bajiq

recover consciousness dahani

rectangular pac sagi nu panyak

red mirah

red ants semöc kremga

reduced reda

reed, kind of kayu riyok

reef karak

refloating bertimon refuse kipas, melaw kipas

register thaqbian

relations adi-bradi

release biyal, plepas

relieve mujoq

rely on sanal

remember bringac, cap

remind bringac

remove ganyaq, ugay

Renong, south Thailand renök

rent siwa, bernyiwa

repair petat, ugay

repay balas

repeated cry of pain or distress adosadoy

repeatedly ungäh-ungäh

repent bralëh-hati, parëq-hati

request mita, soh

reserve pajaq

resist berlawat, blawat

resound hamok, mehamok

rest bradu remay

restrain katak, sengac ${ }^{2}$

retch gelagaq

retreat unol

return baliq, parëq

reveal plihac, belihac

revenge balas

reverse unol

revolve pulas

revolver seton

reward rangwan 
rhinoceros badaq

rib tulak rusoq

ribs of boat kok

rice bag, small supëq ${ }^{2}$

rice gruel bubol, nasi bubol

rice sack bakon

rice saucepan piyoq nasi

rice scarce bras payah

rice, cooked nasi

rice, husked bras

rice, unhusked padi

rich kaya

ridge kebok

ridge capping prabok

rifle senapak

right from taqdëq

right side kanan

Right! böh ${ }^{2}$

righteous bajiq-tepac

rigid kejaq

ring cicët

rinse lingak, ngumol

ripe masaq, puwah

ripen bermasaq

rise bikas

rising tide ayë pasak

rising up galoq-galoq

rite to avert bad luck tolaq bala

river sungay

road jalat ${ }^{2}$

roar bahana

roast salay rob samun, amu

robber penyamun, urak penyamun

rock batu, jangöng

rock seaweed latöy

rod tukac

roll gerlik, grerlik

roll (of a boat) lingak

roll up baloc

roller kayu galak

roof kemubok

roof inside deckhouse geladaq

room ruwak

root akal, yakal, jakal

rope tali

rotten buroq, busoq, gaböq

rough kasal

round bulac, kelilik ${ }^{2}$

row berawac, brawac, rawac

row a boat cäw

royal messenger hulu-balak

royal residence balay

royal servant ribas

rub ginyëh, usöc

rub gently resaq

rub off marine growth ginyëh lumac

rub on isuc, tabëq

rubber getah

rubbing strake sak-pisak

rubbish rapah

rudder kemudi

rule over bela, berbela

run lari, berlari, blari 
runner akal

rust karac

ruthless sumök

$\mathbf{S}$

S.S. Matang matang

sack guni, karok

sack-like bag karok

sacred shrine kramac

sacrifice kerban

sad susah-hati

sail layal, berlayal, blayal

sailor kuli

Saladan village, Lanta Island ladan

salt garap

salted bergarap

salted fish ikat bergarap

salty masët

same serupa

same as serupa jangan

sandpaper krertas rupëq

Sangkao village, Lanta Island isak ka.u

sap getah

sarong kayët berlubak

Satan sitat

satisfied kenyang, puwas

saturated jemu

saucepan piyoq

saucepan, earthern piyoq tanah

save kelimac

saw gaji ${ }^{2}$

say $\mathrm{caq}^{2}$, berkata scabies kudën

scaly skin disease kuraq

scar baroc

scatter kecay, prak $^{2}$

scattered cäq-biräq, cay-baday, pecah-belah

scattered haphazardly celuq-celaq

school rongrian

scissors gutik ${ }^{1}$

scold ucaq

scoop sawoq

scoop out sudöq

scoop up kawoc, rahoq

scoop-net penyawöq, penyawoq

scorch in fire hangös

scorpion langela

scorpion, small and grey cudëk

scrape garöc, kikih, ngaröc

scrape out cukën, menyukën

scratch gamöc, garu, kikay

scream berkäw, brerkäw

screen ketak ${ }^{1}$

screw pulas ${ }^{1}$

scrub ginyëh

scrub oneself ngasaq

scythe parak

sea lawoc

sea cow duyok

sea elephant gajah mina

sea horse, kind of litah bahaya

sea slug tripak

sea urchin taqëm

seagull burok cicang, camal 
seal merka, mrerka

sealing wax malaw

seasick maboq kapan

season musët

seat pedudoq, tepac dudoq

seaward side of Lanta Island blakak satak

seaweed that floats kapkrap

seaweed, edible variety ga.aga

second keduwa

second day after tomorrow tulac

secretly curi², henaq

secure kemas

securely kemas-kemas

see bergari, lihac, lac, melihac

see as shadows berbayak-berbayak

see-saw jangöng

seed benäh, biji ${ }^{1}$

seed of a vine sepa

seed pearls reboq

seek sari, menyari

seek an opportunity nyari tadah

seek the respect of others amët mukha

seep out nilëh, menilëh

select pilëh

self nyawa

self-assertive sumök

self-willed (of a naughty child)

berakan

selfish berhimac nyawa taqasik

sell juwan

semi-cooked rice medaq

send atac, suroh, nyuroh senile nyanyoq

separate rengak

Sepum village, Phuket Island sepap

serious payah ${ }^{1}$

serpent naga

servant penyuroh, prasoh

serve tuhëq, belibas, bibas

serving spoon senoq ${ }^{1}$

set free plepas

set in berkraq

settle a debt padap hutak

seven tujoh

sew jahëq, menyahëq

sexual desire naqsu

shade linoh, payok

shadow bayak

shake beringöq, bringöq, ilik, ketal, ngetal

shallow hole lupaq

shallow winnowing basket nyiru

shaman bumöl

share hagiq, pehagiq, phahagiq, berhagët, phahagët

shark hiyu

sharp tajap

sharpen asah

shave cukol, kukol, mengukol

she nya

sheep kamëk

sheet (of a sailing boat) kelac

shell sipoc

shell, kind of cukhon, kabök, läw-läw

shelter dangaw, linöng 
sheltering kelingöng, nöngkelinöng

shine bersaya, suwal, teläl

shine steadily bersura

ship kapan

ship festival belacak, pelacak

shirt pocket thok baju

shiver ngetal

shoe paqtapaq

shoot panah ${ }^{2}$, timaq, tunas

shooting star bitak brasaq

shop keday

short panaq

short beard bulu daga

short-tailed monkey broq

shoulder bahu

shout suraq, bersuraq

shout angrily tepëq

shout out kepäw

shovel penyudöq

shrivel layu

shrivelled pipëh

shrub with large leaves lahok

shrub, kind of kabol lawoc

shut kapus, tudok

shut eyes pejap

shuttle bubon

sick sakëq

sick of fever sakëq demam

side belah ${ }^{2}$, rusoq

side by side nyapëq ${ }^{2}$

side beam of boat bidik prahu

sideways hirik ${ }^{1}$ side whiskers bawoq

sigh menyawa besal, bernyawa besal

Sikh megali, sedagah

silver piraq

silver cup batën piraq

similar to serupa kaq

sin dusa

sinews urac

sinful berdusa

sing nyanyi, menyanyi, bernyanyi

singe layol

sink lemas, talap

sit dudoq

sit by fire after childbirth dudoq dëq api

sit crosslegged dudoq bersila

sit in water renap

sit meditating dudoq berhimac, dudoq bringac

sit with legs at side dudoq hirik

sit with legs straight out dudoq mujol

six nam

skin brulak, kulëq

skin disease panaw

skin of snake sarop

skink keparok

skull pala hatu, tulak pala

sky langäq

slander upac

slap tepoq

slap face tapal

slash bahoq

slash down tebas 
slave prasoh, pharaq

sleep lina

sleep face down jerlepök

sleep in late mengelok

sleep on side hirik ${ }^{2}$

sleeping mat lepac

sleepy mengatoq, ngatoq

slice tipäq

slice of $f$ sayac

slide gusol, lachal

slide off grusol

slimy la.ël

sling taboy

slip grusol

slip off terpeliq

slip over terpeliq

slippery licët

slope tebik

sloping jal-lajal

slow lamac

slow down brerda

slow to learn lidah tegal

slowly lamac-lamac, pelat

sluice iriq

small dikiq

small amount miqdemiq, miqdumiq

small coconut putiq

small cross timber legeta

small deer kiyak

small portions of rice anaq bras

small reaping knife rengap

Small Yao Island mabok demiq smart pedëh

smashed hacol

smear cutëk

smell ba.u, huwis

smelly busoq

smile kunyëm

smiling gelaq-gelaq

smoke asaq, isaq, me.isaq ${ }^{1}$

smoked fish ikat salay

smooth licët

snake ulal

snap lekap

snapped patah $^{1}$

snatch away jepuc

sneeze brersët

so jadi $^{3}$, kaqgini ${ }^{1}$, kaqgiter ${ }^{1}$

so that bida $^{2}$, bri $^{4}$

soak renap

soap sabot

soar lamok, melamok

sob gagiq

socks setukin

soft halus, lemah

soft and spongy lemah-lemah

soft drink ayë minäq

soft-hearted lemah-hati

soldier thaqhan

sole of foot tapaq, tapaq kaki

some setengah ${ }^{1}$

something written penulëh

sometimes berkali, dak-kadak, sac ${ }^{1}$

son nanaq kilaki 
son-in-law menatu

sorcerer bumöl hatu, urak makay

sore sakëq, liyak

sorrowful bahati

sorry gasaq menyesan

soul hati

sound suwara

sound of fish on surface raq-raq

sound of light rain ruraq-ruraq

sound of rapid removal of offending spirit bus

sour bari

south barac daya

south-east selatat

south-east wind angën selatat

southern wind angën barac daya

south-west wind angën jarop panaq

sow pac-prac, prak $^{2}$, puy-pruy

space between the toes celah jari kaki

space rawak

span jekan

sparrow burok ciyaq

speak melaw, bermelaw, kata

speak briefly melaw sikac

spear serapak, bulus

special dress maqalac

species macap

spectacles crermën mata

speech permelaw

spider gelawaq

spill tupah, bertupah

spin a rope pulas tali spirit hatu, kerlok, semengac

spirit feast kenuri

spirit festival pahadak

spirit house balay datoq, rumah datoq

spirit of a place tuhat tanah

spirit of shrine kramac

spirit of the dead badat

spirits araq

spit out pethuy

spittle ayë liyol, liyol

splash suwac, grercuk

splashing up pelay

split pecah, riciq

split in two belah ${ }^{1}$

spoiled bari

spoilt benasa

sponge kemöq ayë

spoon sudu

spoon out senoq 2

spotted shark betäw

spray sebul

spray-screen ketäq ${ }^{1}$

spread tapën

spread disease hawal ${ }^{1}$

spread out apal

spring mata ayë, sepring

spring out of water mawös

spring tide ayë besal

sprinkle prerciq, puy-pruy, sibal

sprout bucoq, tumoh, tunas

spy mesoq

square baya, pac sagi 
squash a flea tinas

squashed pipëh

squat belikal, dudoq bertingok

squeeze hapëq, kepiq

squid henus

squint bilas

squirrel tupay

Sri Raya town, Lanta Island patay raja

stab tikap

stabilising fins sayaq

stable tetaq

stair tanga

stamp on kacaq, latap

stand diri, berdiri

star bitak

starfish, type of bulu babi

start setat

startled terkejuc, gasaq terkejuc

startled out of one's wits tergamam

starving kerbelol

state haja ${ }^{2}$

stay bradu

stay or travel with tupak, menupak

stay temporarily berbagat

stay together hibot

stay with nupak

steady senan

steal curi ${ }^{1}$, menyuri

steam us

steamed fish curry supaw

steer boat at angle to waves and wind picok steer for tenöng

steer parallel to waves melitak

steersman tikök

stem ratik

stempiece of boat böya

step lakah ${ }^{1}$

step on Moken boat cabak

step over lakah ${ }^{2}$

stepfather paq tiri

steps out melakah

stern patac

sternpiece böya kemudi

stick on tapäq

stick out tongue ulä

stick to mengasaq

stick together kraq, berkraq

sticky liyac

sticky rice nasi puloc, padi puloc, puloc

sticky rice preparation, fried and pounded pik

stiff kebas

still kemën, lagi ${ }^{2}$

sting sengac ${ }^{1}$, penyengac

stingray pari, phrerlak

stingy maläq

stinking hanyä

stir bersudu, haru

stirred up grercuk, hati hangac

stomach proc

stone batu

stone mortar lesok batu penyelöq

stooped bukoq 
stop bradu, berbradu

stop a fight sabal

stop at singah

stopped up kemuk

stopper tapoq ${ }^{1}$

store pungöc taroh

story certa, crerta ${ }^{1}$, pasan

straight remak $^{1}$, tepac ${ }^{2}$

straightaway wac ${ }^{1}$

strain (wood) tekat

strait luwaq

strange peläq, peläq-peläq

strangle cekäq

strength urac

stretch a pace tuhoq lakah

stretch out tuhoq

strike ladok $^{1}$, patoq

strike a match garäh

string made of cotton benang löq

stroke resaq, usöc

strong tegal urac, tegal

strong wind riboc

stubborn batah, tegal-hati

study belajal

stumble cebiq, sok-sok, tedus

stumble backwards terbrengaq

stumble forward jok-jok

stupid budö

style cara

subject lagu, pasan

succulent lemaq

suck isaq, umu suffer tahat

sufficient sabrasa

sugarcane tebu

sulphur belirak

summarise regac

summit bucoq

summon memawa, pangin

sun mata.ari

sunbathe salay ari

sunken lahöq ${ }^{2}$

superhuman sidi

support senan

sure tetu

Surin Island lathaq ${ }^{1}$

surprise! boq ${ }^{2}$

surrender bralah

suspend gatok

swallow telat, yak-layak

swamp tree taksal

sway in walking degak

swear abol, supah, bersupah

swear word hapot maq, terkimaq

sweaty daki

sweep kikay, mengikay

sweep away kipas

sweet manëh

sweet basil biji leba, biji kemangi

sweet potato bemanëh

sweetsmelling spices kelekaq nu ba.u

swerve liköq

swim berdenang

swindle kicöh 
swing ayut, berlayut, riway

swing arms riway tangan

swollen barah, basan, kemok

sword pedak

swordfish ikat tuhoq, ikat culas, phrengan

symbol tana ${ }^{1}$

syntactic particle ter

$\mathbf{T}$

table toq ${ }^{1}$

table papat toq

taboo pupoh

tack phiraw

tadpole ruwaq-ruwaq

tail ikol ${ }^{1}$

take amët, bawa pi, berpi

take a photo sitaq rupa

take advantage of tupak

take away amët pi

take back berbaliq

take oath supah

take off (clothes) ugay

take trouble to payah ${ }^{2}$

taking a wife berbini

talk or walk in sleep mamon

tall tingi

tamarind jawa

tamarind tree asap ${ }^{2}$, puhot asap jawa

Tamil kelik

tangled kusoc

tape recorder tëp

tapered lucuh taste sröq

tasteless cröy, tawal2

tasty nyaman

taut cikak

tax asën

teach ajal

teacher guru, khru

tear culat

tears ayë mata

tease me.ajaq

tease playfully metul

teasing kerbetol

teen belas

teeth gigi

teeth strong keyaq

telegram tali graq

telephone tali graq

telescope trupuk

tell bitahu, carëq, nyarëq, menyarëq

tell a story or fable crerta ${ }^{2}$

temper pejal

temporary hut saröq, rumah saröq

tempt ajaq

ten sepuloh

ten thousand selaqsa

tens puloh.

Tepaw Island pëq buraw

test löklihac

testicle telol

Thai si.ap

Thai chopper tamäq si.ap

Thai coin setang 
Thai drum kedumaq

Thai headman kemenan

Thai salad krabu

than dëq ${ }^{1}$

that $\mathrm{caq}^{1}$, itu

that day ari ter

that which nu-caq

That's correct! kena dah

That's enough! genaq dah, jadi dah

the koq $^{2}$

theatre wayak

then baru $^{2}$, kaqgiter ${ }^{1}$, lalu ${ }^{2}$, waqtu itu

there daw itu, ho, kiyuh

therefore krana ini, krana itu

they kunya

thick teban

thief penyuri, urak penyuri

thin kurus, nipih, susoc

thing bena

things kelekaq

things done perbuwac

think kira

think about berhimac

think of ingac

think through to a decision temus kira

thirsty daga, dehaga

thirteen tiga-belas

thirty tiga-puloh

this ini $^{1}$, ni

this morning pagi nitay

thole teladoq

thorns duri thousand ribu

thread benang, cucoq, urac

threaten angaq

three tiga

throat brergöq

throttle crerkäq

throw lipal, melatik

throw down violently hempas

throw into the sea buwak lawoc

throw out suwac, melatik

throw upwards lamung

thrown away terbuwak

thrust a paddle outwards huwëq

thunder gutol

tick ketibac

ticket tikäq ${ }^{1}$

ticklish geli, latah

tide coming in pasak ${ }^{1}$

tie ikac

tie down sirac

tiger brutat, brutat basa balol

tiller caciq kemudi

tilted cihäq

time pukol, waqtu

times kali ${ }^{1}$

tin calok, tëng

tin dredge bölä

tin ore bijëh

tinned milk gulëng

tiny rinyiq

tiny piece töc

tip pucoq 
tired penac

tired of jemu

to kaq1, kaqpada

tobacco ubac jawa

toe jari kaki

together sama, raquq ${ }^{2}$

together with sama-sama

toilet penyarat

tomato trök mirah

tomorrow mahpagi

tongue lidah

too juga

toothache, severe sikën gigi

top pucoq

top of foot blakak kaki

topping iti

torch damal, jamöng, käkëp, yamöng

torch batteries ubac pelita käkëp

torch to attract fish jamöng suloh ikat

torn cicäq ${ }^{2}$

tornado terpiyok

torpedo terpido

toss cangah, lipal, prak², taboy, tapih, tuhoq

touch kena' ${ }^{1}$, petöq

touch shoulder labat

tow irëq

towkay tökkë

trace bekas ${ }^{1}$

tradition hadac

traditional manohra dance nora

trample on latap

transgression kerlebëh transport (people and goods) pedoq

travel jalat ${ }^{1}$

travel with nupak

tread on kacaq

treat chiya

tree kayu, puhot ${ }^{2}$, puhot kayu

tree bean petay

tree bean, edible mungay

tree stump tungon

tree, kind of bikuy, kelubak, kelukuy

tremble beringöq, bringöq, ketal

tribe palah

trigger katëh

trip ti.o

trouble gadoh $^{1}$, susah

troubled gadoh-gadoh

troubled in heart gadoh-hati

trousers seluwal

true sungoh

truly troq, sesungoh, sungoh-sungoh

truly good bajiq sesungoh

trumpet selunay

trunk bermuy

trunk of tree or plant prerdu

trust taroh-hati

try out löklihac

try to kuwasa

tube pahëq ${ }^{2}$

turbulent dras ${ }^{1}$

turbulent water ayë dras

turmeric gamën

turmoil kelacuq 
turn beralëh, bralëh, ligac kalëh, pulas

turn a millstone gilik $^{1}$

turn around siräq ${ }^{1}$

turn aside cipak, meli.aw ${ }^{2}$, singah, tiliq

turn over karap

turn something alëh

turtle kura, penyu

turtle shell sisiq

tusk of wild pig tarik

tutelary spirit datoq

twelve duwa-belas

twenty duwa-puloh

twice duwa-kali

twig ratik

twine around kröt

twinkle ngetäq

twinkling ngetäq-ngetäq

twins kemal, nanaq kemal

twist belëq, likal, pulas

twist together sipay

twisted sinew salah urac

two duwa

\section{$\mathbf{U}$}

ugly udoh

umbrella payok

uncle ma, wa

understand masoq dëq hati

unequal-sided bicok-bicok

uneven bicok-bicok, käq-ukäq

unevenly genäq-genäq

unhusked rice padi uniform maqalac

united bersama-hati

unmarried daughter nanaq radara

unripe matah

unsettled cacaw

unstable galik, hati cacaw

untamed liyal

untidy semaq, udoh

until tedaq, terdaq, tedaq röc, yu

until that yu-caq

upper leg paha

upper storey lötëng

upright tepac ${ }^{2}$, hati tepac

upturned koq-crerkoq

Urak Lawoi' race baksa urak lawoc

urgently gangu

urinate kemëh, kermëh

use guna, makay, pakay, suroh

use an evil spirit makay hatu

use sparingly kelimac

use witchcraft for sick person makay ayë lemu

useful berguna, terpakay

utter seboc

uvula töyketöy

\section{V}

valley celah bukëq, rawak bukëq

value rega, brerga

vanish lengäq

vapour us

various jenäh-jenäh 
vegetable taroq

vehicle setri

venom bisa

verandah pethöl

verse tenös

very brapa ${ }^{3}$, phrat ${ }^{2}$, terlalu, troq-troq

very few dikiq-töc

very fine lumac

very many banyaq sungoh

very much selalu

very small demiq-töc, lumac, rinyiq, töc

vibrating kethäl

view dudu

vigorously gasaq

village tupoq

village in Krabi province bukan

village leader kemulu, pala tupoq

village on Jum Island lak-ngatöc

villages on Lanta Island bagat pulaw, bunën, butik, daqaw, lubuq para, tapö

village on Peepee Island, Krabi petok

village on $\mathrm{Pu}$ Island sungay brana

violin berjula, pejula

virgin radara

visit jengöq, menyengöq

voice muloc, suwara

vow bersawoc, niyac

vulture i.äk

W

wages gaji ${ }^{1}$

waist pingak wait nati, menati, tungu

wait a moment nati sac

wait a while nati duhulu

waiting bernati

wake up dehani

walk jalat ${ }^{1}$

walk like a drunk hayok

walking berjalat

walking-stick tukac

wall of house dining

wander baksac

war prak ${ }^{1}$

warm sa.öp

warm oneself berdi.ak

warm with flame layoy

wash basoh, pulëh

wash hair langä

wash the head langä pala

watch out lihac-lihac

watches over mejaga

watching on guard bertungu

water ayë, celöl

water blisters lutoq

water bubbling ayë brernäh, ayë belay

water buffalo kerbaw, krerbaw

water drum thok ayë

water jar buyok

water jar, wide-mouthed gasat

water not turbulent ayë höy dras

waterspout terpiyok

wave ingöq-bringöq

wave the hand akëq tangan 


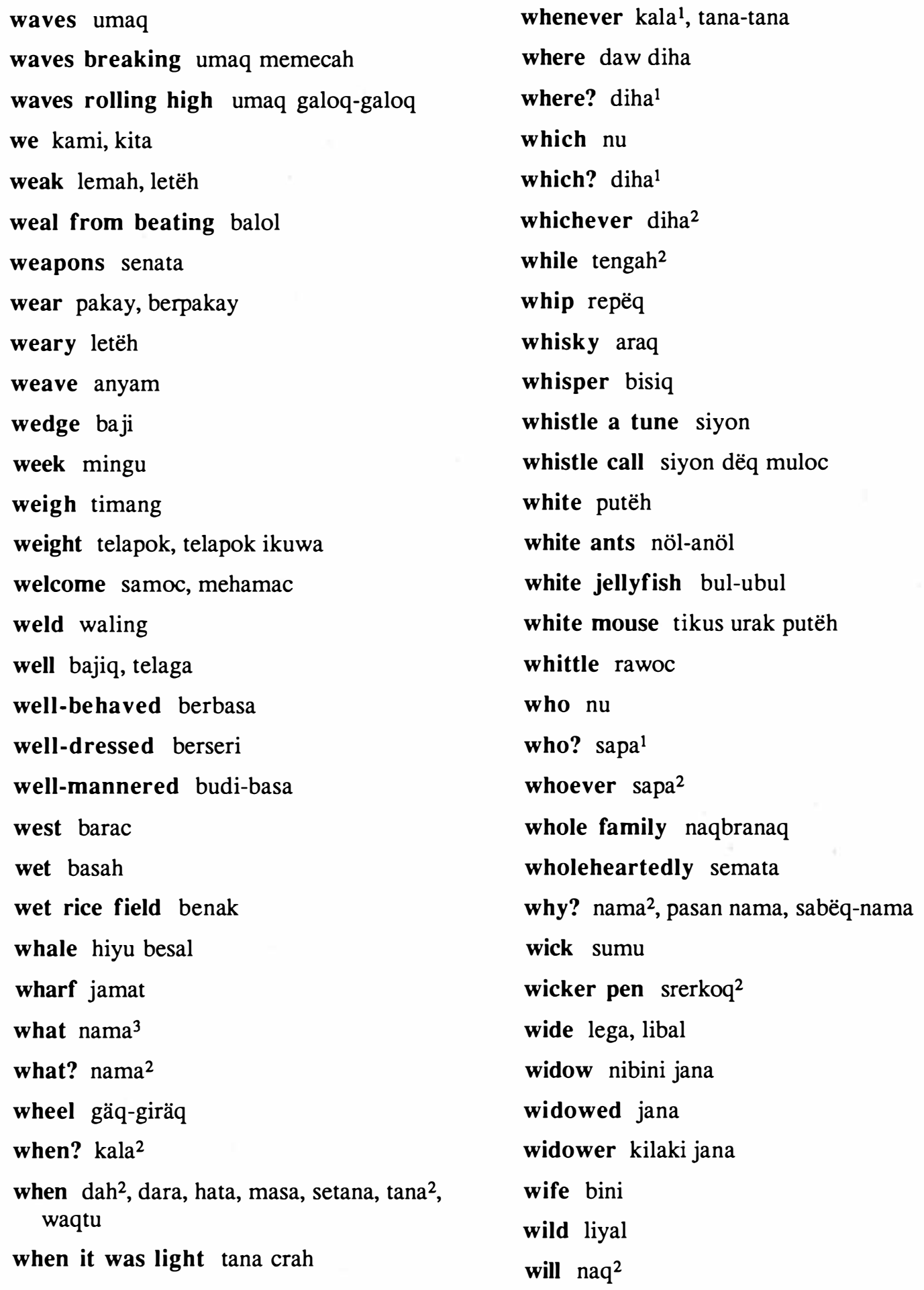


willing to yöm

wind angën, likoq

windlass kilas

window tikaq

windpipe bökbrök

winged insect biyok, biyok thëq-thëq

wings sayaq

wink ngetäq sebelah

winnow tapih

wipe sapak

wipe on lumol

wipe the face isuc mukha

wire daway

wise akan, ba.akan

wise man nujop

wish asan $^{2}$

witchdoctor bumöl hatu, semiya pakay ayë lemu, urak berubac

witchdoctor's spirit house rumah pelët

with jangan ${ }^{2}$

with arms outstretched berdepa

with difficulty sepuc-sepuc

withdraw unol

withe huwi, uy

witness saqsi

woman nibini

woman, young unmarried nibini radara

wood kayu

wood of protection kayu phehadak

wood, kind of bilah, temesu

woodpecker blatoq

wooden mask phrat $^{1}$ woodworm buboq

word permelaw

work kerja, krerja

work for wages makat upah

working berkrerja

world deniya, benuwa

worm hulac, temiloq, upat patay

worm used for bait pupot

worn out buroq, letëh

worship semah, menyemah

wound luka, liyak

wounded berliyak

wrap around berbac, sapoc ${ }^{1}$

wrapped around bersapoc, pöcpöc

wrist chains gari

wristwatch jap tangan

write garäh, tikäq² ${ }^{2}$ tulëh, menulëh, nulëh

wrong salah ${ }^{2}$

wrong behaviour salah lagu

\section{Y}

Yao Island mabok

yawn nguwaq

year tahot

yeast ragi

yellow kuning

yellow rice bras kunyäq

yes er ${ }^{1}$, ya

yesterday kemari

yoke koq ${ }^{1}$

you kanyaw, kaw

young muda 
young of animal anaq

young woman radara

younger sibling adi, miq

youngest child busu, nanaq busu
$\mathbf{Z}$

zalacca palm kumal

zealous for tuhëq

zigzag likök-likök 


\section{APPENDIX}

ari pelacak day of spirit festival for floating spirit boat: This is a festival celebrated twice a year when a special boat is made and floated out to sea to take away any bad luck which might trouble the village in the monsoonal season then starting.

ari phahadak day of spirit festival for planting crosses: This festival is linked with /ari pelacak/ when seven crosses are planted along the beach in front of the village to prevent any bad luck from coming to trouble the village in the new monsoon season. These two festivals are referred to in footnote 5 of the grammatical study.

ayë lemu incantations: This is the general word used for anything connected with the Urak Lawoi' system of witchcraft.

bilakäl ancestors: This refers to the ancestral spirits, both of remote ancestors and also of older people who have died recently. If their descendants do not pay due respect to them they may inflict illness or some other calamity on the family. The person afflicted then seeks a witchdoctor, /bumöl ayë lemu/, who consults with the spirits to ascertain which ancestor has been offended and what must be done to appease him. This may involve a feast, a drinking party, a ceremonial dance or some other performance.

brubac chant charms, apply medicine: /brubac/ refers to the practice of /ayë lemu/ 'witchcraft' by a /bumöl/ 'a shaman'. There are many variations of this, but one common form is where the shaman stands or sits beside the afflicted person, murmurs an incantation into his folded hands, then passes his hands from head to foot over the patient three times, at the same time spraying him /sebul/, with spittle or with air from his mouth. On the completion of the third pass the shaman uses a motion of his hand to cast the offending spirit out to sea, /buwak kaq lawoc/. As stated under /pupoh/ 'taboo' care must then be taken that no salt water shall enter the house, permitting the spirit to return.

datoq tutelary spirit: /datoq/ are legendary persons with mystic powers, located in a particular area. They are benevolent, unlike the /hatu/, and may be prayed to in times of need, with special offerings, but not with blood sacrifices. The /datoq/ is worshipped more than God because God is remote above, while the datoq is nearby to guard the village.

dudoq dëq api give birth, sit by fire after childbirth: 'sitting by the fire' is a custom followed after childbirth, usually now for seven days, but formerly for fifteen days. This is not /patak/ 'tradition' or /ayë lemu/ 'witchcraft', but /bri nya tuhol - bri nya krik/ 'so she will be dry'. Often a hearthstone, /batu tuku/, or piece of iron is heated and wrapped in cloth and used as a hot-water bottle. It is felt necessary to keep the mother warm to hasten her recovery. In some cases they use the root of a shrub in /ayë lemu/ 'witchcraft'. The person who is /berguru/ 'skilled in witchcraft' asks the /tuhat tanah/ 'lord of the ground' for the root /jakal kayu/. It is pulled up, cut into thin slices and mixed with betel nut. A charm is then murmured over the mixture and the mother chews it. 
kenuri prahu feast eaten in boat: This is a feast shared with the spirit of the boat to seek her cooperation for the fishing season ahead. This is apparently a Thai belief as there is no UL word for the spirit and she is called by the Thai name/mä yaa naang/. The men let off crackers and put garlands on the prow of the boat. Thai people avoid treading on the prow, for fear of offending the spirit.

kramac sacred shrine, spirit of shrine: /kramac/ is a sacred shrine, supposed to be possessed of mystic powers. It is occupied by a spirit who was once a tiger, a crocodile, a snake, or one of the remote ancestors. It has magic powers, can see man and be angry with him. It can be propitiated with incantations, offerings, etc. It is usually located on a cape, in a tree or in the /balay tupog/, the shrine occupied by the guardian spirit of a village.

nora traditional manohra dance: The Urak Lawoi' manohra /nora/ is a traditional dance leamed from the ancestors, which involves dancing and singing the ancient tribal legends. The leader /pala balay nora/ sings a portion of the legend and the group of singers repeat it as a refrain /menuroc/. This is accompanied by men drumming on the /bring-bring/drum. If they drum on the /gernat/drum, it is then called the /nora miyok/. The dancers are usually women, but if any men join in they wear a wooden mask. Sometimes the manohra is performed to carry out a vow made to the spirits, in which case the shaman opens the ceremony/buka balay/by inviting the ancestral spirits to come and watch. At other times the manohra may be performed without carrying out a vow, but it is still commenced by a spirit ceremony where the shaman calls on the ancestors. Formerly there was a man called Sitan at Yuban village who was the teacher of the manohra skills but he died 40-50 years ago. Now the manohra is dying out as the young people are not interested in hearing or performing it.

nyuroq go underneath: At an UL funeral when the coffin is taken from the house to go to the cemetery it is held up while the female relatives and children go underneath it three times. Noone seems able to give a reason for this practice.

patak forbidden by tribal tradition, also berpatak: /berpatak/ is not /ayë lemu/ 'witchcraft', but includes prohibitions such as:

1. Abstinence from certain foods for medical reasons, such as to hasten recovery from fever or illness.

2. Newly-wed couples must live for three days in the house of the marriage ceremony, must abstain from work and from sleep by day.

3. The mother with a newborn child has severe restrictions as to what she may eat. This is not /ayë lemu/ but/timaw bri salah makat/'don't want to eat the wrong things'. She may eat /ikat salay/ 'fried fish', /ikat jujon karap/ 'fish dipped in salt', /ikat rebus/ 'fish boiled with salt', and may /oq ayë hangac/ 'drink hot water'. This was the ancient custom but many modern mothers have discarded this custom and eat more nutritious food. The period used to be fifteen days but now is more of ten seven days, the time when they are sitting by the fire. Tradition says that failure to observe this will cause /darah nyanyäq bri nya mati/'the blood will rise so that they die'. See /dudoq dëq api/.

pupoh taboo: This includes household goods used in a witchdoctor's ceremony which are then taboo and set aside not to be used for three days. Also after a witchdoctor's ceremony when the spirit has been cast out to sea /buwak kaq lawoc/, no salt water must enter the house. 
Anyone who has been to sea must wash his feet in fresh water before entering the house to keep the spirit from returning.

sebul spray: This word is used for the various ways in which spraying is carried out, but it also refers to the action of the shaman when he is using witchcraft to help someone who is ill, etc. As part of the ceremony, described under/brubac/, he sprays the patient with air or with spittle from his mouth.

takan string around waist, wrist, upper arm or neck: This is the sign of a vow but opinions are divided as to whether it is /ayë lemu/ or not. In some cases it is a sign that some relative or close friend has in effect adopted a child to save it from an illness. In this case the person who puts on the string is called /paq berhidoq/ 'father who gives life' or /maq berhidoq/ 'mother who gives life'. In some cases the string may have a tube with writing in it from a Thai or Malay witchdoctor.

tolaq bala rite to avert calamity: This is a ceremony to avert calamity similar to the /pela jak/ ceremony referred to above. In some villages it is performed twice a year at the change of the season, in others it is only performed when a special need is felt for it. Ôriginaily it was a solemn rite with no dancing, singing, drinking, smoking or loud talking but it is now more of a festive occasion, with heavy drinking and dancing.

urak makay sorcerer: An /urak makay/ is a sorcerer, suspected of using black magic, /makay hatu/, to bring illness or other trouble to someone else, either to improve his own spiritual wellbeing, or else so that the afflicted person will have to seek his help to enable his recovery. The sorcerer is greatly feared in comparision with the /bumöl/, who is respected as someone who uses white magic to help those in need. 
